\title{
Sustaining reservoir use through sediment trapping in NW Ethiopia
}

Mulatie Mekonnen Getahun 


\section{Thesis committee}

\section{Promotor}

Prof. Dr L. Stroosnijder

Professor of Land Degradation and Development

Wageningen University

\section{Co-promotors}

Dr S.D. Keesstra

Associate professor, Soil Physics and Land Management Group

Wageningen University

Dr J.E.M. Baartman

Assistant professor, Soil Physics and Land Management Group

Wageningen University

\section{Other members}

Prof. Dr J. Wallinga, Wageningen University

Prof. A. Cerdà, University of Valencia, Spain

Prof. Dr J. Nyssen, Ghent University, Belgium

Dr. L.H. Cammeraat, University of Amsterdam

This research was conducted under the auspices of the Research School for Socio-Economic and Natural Sciences of the Environment (SENSE) 


\section{Sustaining reservoir use through sediment trapping in NW Ethiopia}

\section{Mulatie Mekonnen Getahun}

Thesis

submitted in fulfilment of the requirements for the degree of doctor at Wageningen University

by the authority of the Rector Magnificus

Prof. Dr A.P.J. Mol,

in the presence of the

Thesis Committee appointed by the Academic Board

to be defended in public

on Wednesday 14 December 2016

at 4 p.m. in the Aula. 
Mulatie Mekonnen Getahun

Sustaining reservoir use through sediment trapping in NW Ethiopia 176 pages.

PhD thesis, Wageningen University, Wageningen, NL (2016)

With references, with summary in English

ISBN: 978-94-6257-910-1

DOI: $10.18174 / 388775$ 


\section{Acknowledgement}

It is time to acknowledge those who supported me during my PhD study. To start I would like to thank my promotor Prof. dr. ir Leo Stroosnijder for accepting me as a PhD student and for his scientific guidance. Thank you for your planned and endless support. I learned a lot from you not only in the scientific environment but also in life skills.

I'm particularly thankful to my co-promotors Saskia D Keesstra and Jantiene JM Baartman for their dedication and unwavering support. Your door is always open, I never remember any time of pre-booking for any discussion. You are really kind, helping and positive. Saskia, your support starts before starting my PhD when I was applying for NUFFIC for funding and continued to the end of my PhD journey. Thank you for all. The three persons in my life who I will ever call my teachers Leo, Saskia and Jantiene. I would like to thank Prof. dr. Coen J Ritsema for giving me valuable ideas for the proposal and co-authoring two of the papers. My gratitude to Jerry Maroulis, for his precious assistance, editing papers to improve the English language quality and co-authoring two of the papers.

I am thankful to the Netherlands Universities Foundation for International Cooperation (NUFFIC) for funding the PhD program through their Netherlands Fellowship Program (NFP) and the Amhara National Regional State, Bureau of Agriculture for granting me study leave with a half salary payment. I would like to thank Wageningen University, Amhara Regional Agricultural Research Institute, Bahir Dar University (Water resource engineering faculty), Adet Agricultural Research Center, and Water and Land Resource Center for providing me field equipment and Bahir Dar soil laboratory center for helping me in soil texture analysis.

I would like to thank Ato Gedu Andargachew, the former head of BOA and the current president of the Amhara National Regional State, for facilitating my study. My special thanks to Dr. Teshome Walle and Dr. Birru Yitaferu in writing recommendation to witness my capacity as a PhD candidate. My deepest thanks go to Aytenew $\mathrm{E}$ and Ayehu $\mathrm{Z}$ for creating good environment for data collection.

I am thankful to all staff of ANRS BOA, Minilek, Bitew G, Birara, Mehare, Berihun, Baye, Dawit, Belay T, Chalachew, Yeshiwas, Yalemzeud, Belay M, Tewachew, Bitew, Achash, Mengistu, Misganaw, Gebeyaw, Aynadis, Habitamu, Baych, Fitalew, Melkamu, Getachew and my colleagues and friend from Wageningen University SLM group: Rens, Jos, Luuk, Aad, Violette, Klaas, Demie, Martine, Michel, Diana, Sjoerd, Henny, Harm, Piet, Carlos, Lingtong, Sija, Recardo, Akalu, Berhane, Meskerem, Selamawit, Mohamed A, Mohamed H, Samuale T, Samuel A, Ammare, Karrar, Celia, Govinda and Akram.

I would like to thank Marnella, Esther, Annelies, Anita, Henny and Siawash for providing timely administrative and financial arrangements. Marnella van der Tol, thank you for your precious assistance, motivating words and ever bright smile.

I am also grateful to thank family members, Emuhay Belynesh Desta, Yeshitila A, Tirualem $Y$, Muluadam G, Ayalew M, Fenta M, Teje M, Yigarde M, Mengaw T, Yeshmbel T, Assefu K and Anguach D.

Finally I give my appreciation and love to my beloved wife, Ethiopia Abesha, for her love, support and patience during my long stay away from home, and taking care of our children. My love and appreciation go to my daughters, Nardos and Mahilet and my son Kaleab, who are my strengths for success. 


\section{Dedication}

I dedicate this PhD thesis to the memories of my father, Ato Mekonnen Getahun, my mother, W/ro Asselef Biresaw and my sisters (Yeasabe Mekonnen, Balechiw Mekonnen and Yirbebu Mekonnen) whom I never forget forever. I admired my mam and dad forever, for sending me school to learn without having any formal education and for their generous support. They are my practical lessons of devotion, commitment, kindness and affection. I am proud of them ever. Were they alive, they would be very happy for me. May God rest them in peace!

\section{opthins}

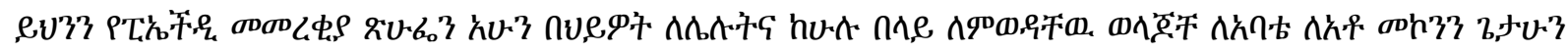

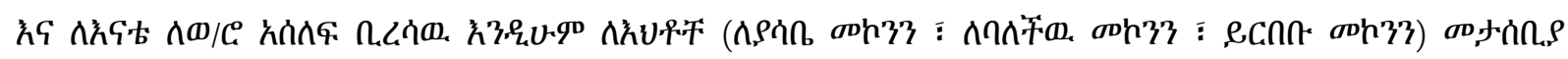

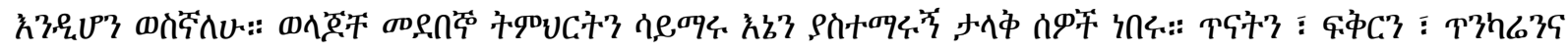

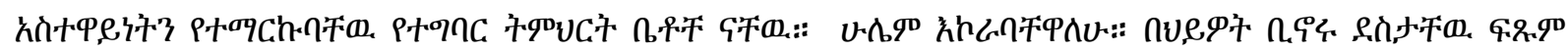

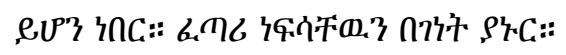




\section{Table of contents}

Chapter 1

Chapter 2

Chapter 3

Chapter 4

Chapter 5

Chapter 6

Chapter 7

Chapter 8
Introduction

Spatial and temporal variations of sediment entering Koga reservoir, NW Ethiopia

Soil conservation through sediment trapping: a review.

Sediment trapping with indigenous grass species showing

differences in plant traits in NW Ethiopia

Evaluating sediment storage dams: structural off-site sediment trapping measures in NW Ethiopia

Reducing sediment connectivity through man-made and natural sediment sinks in the Minizr catchment, NW Ethiopia

Adapting LAPSUS_D model to simulate runoff and sediment yield in Minizr catchment, NW Ethiopia

Synthesis

References

Summary

Certificate of the Netherlands Research School for the SocioEconomic and Natural Sciences of the Environment (SENSE)

Curriculum vitae and author's publications
95 

Chapter 1

\author{
Introduction
}

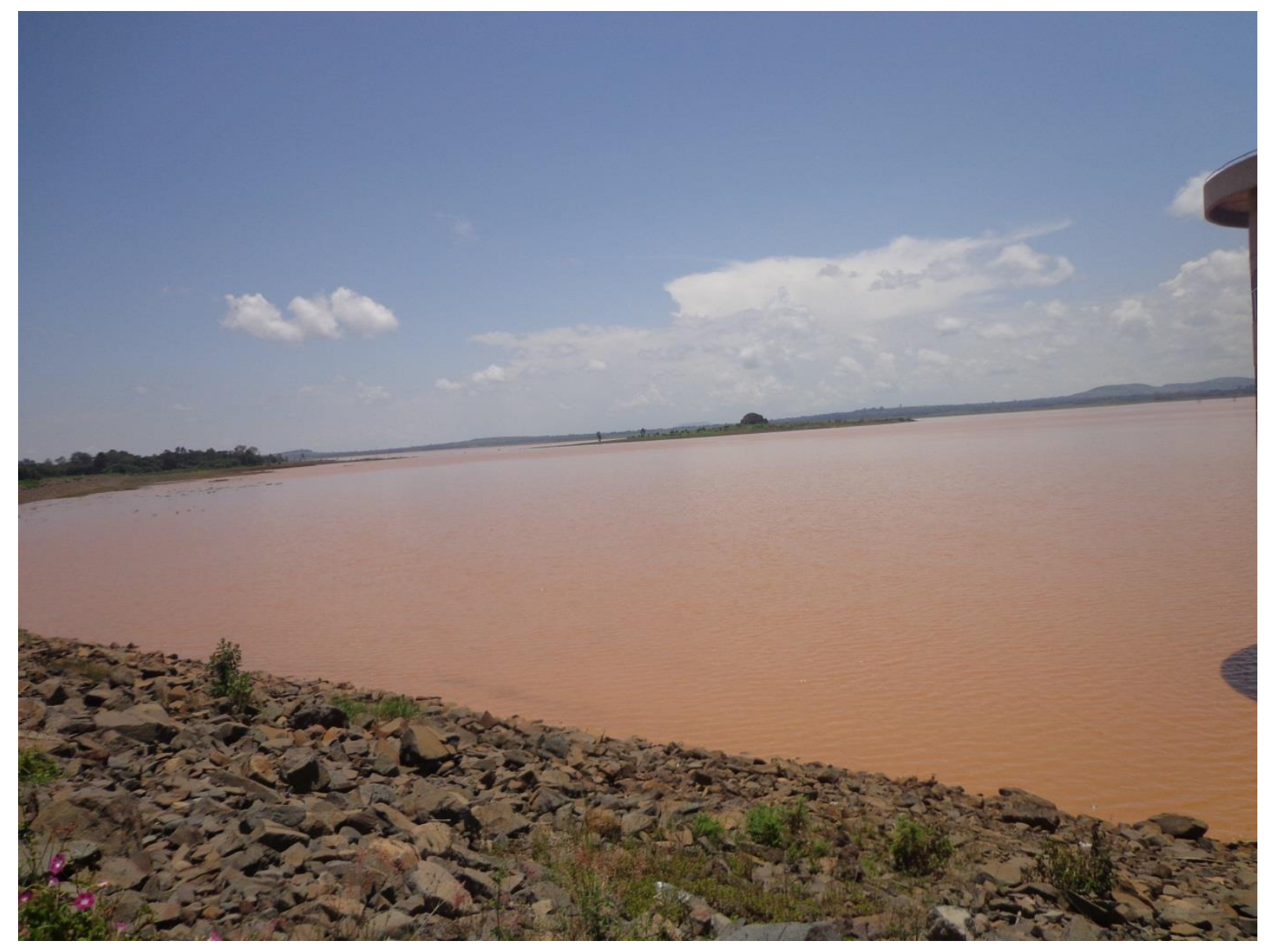




\section{Introduction}

\subsection{The problem}

Koga reservoir is one of the largest reservoirs in northwest Ethiopia, Figure 1.1. It is a key project for the Ethiopian government, towards achieving food self-sufficiency at the regional level.

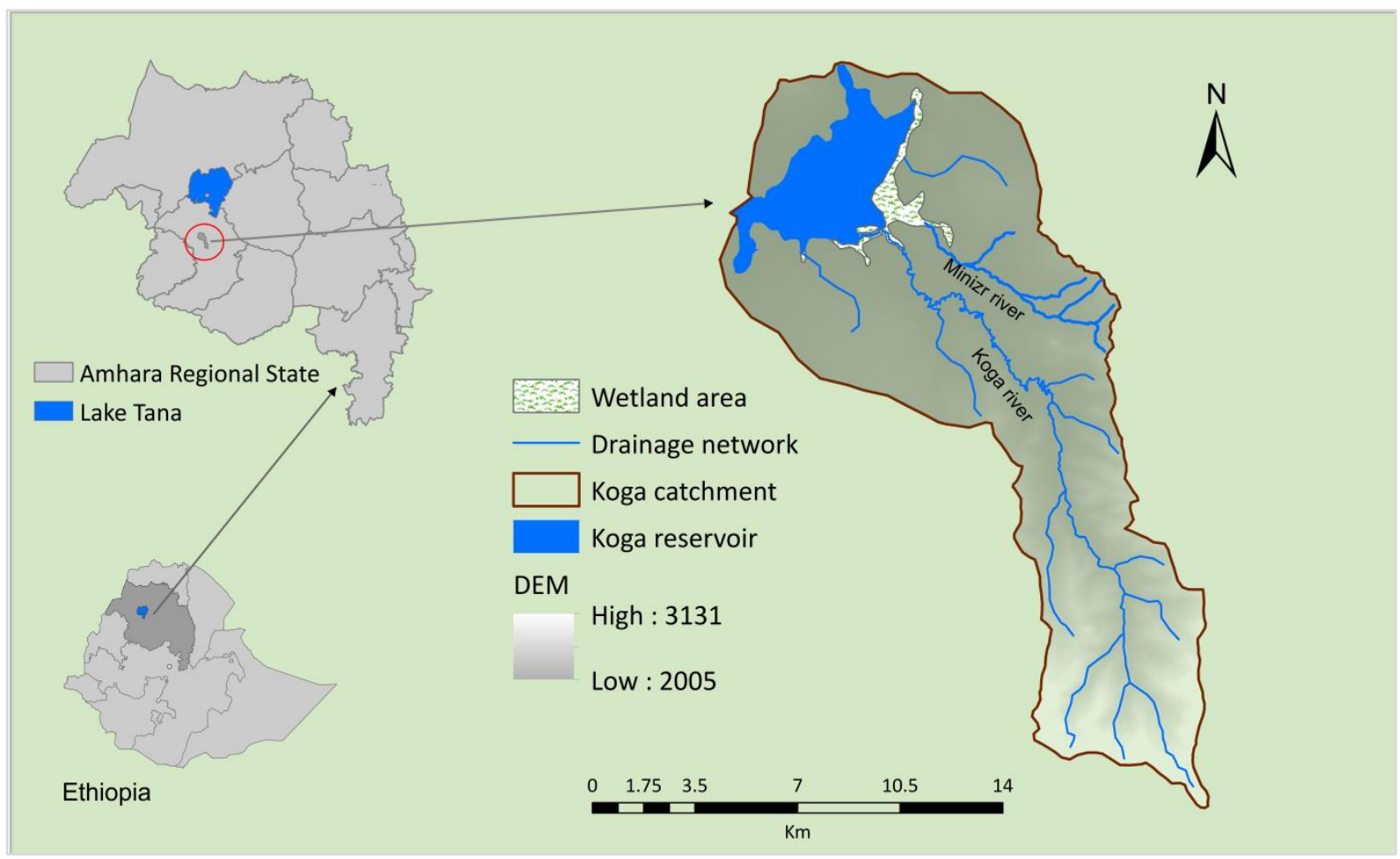

Figure 1.1 Map of Ethiopia, Amhara Regional State and Koga reservoir

Koga reservoir was constructed at the outlet of Minizr $\left(20 \mathrm{~km}^{2}\right)$ and Koga $\left(143 \mathrm{~km}^{2}\right)$ catchments in 2008 to collect surface runoff and river water for irrigated agriculture. Koga is the major river transporting water from Koga catchment to Koga reservoir and Minzr is the second largest river transporting water from Minizr catchment to Koga reservoir.

Koga reservoir can store about 83 million $\mathrm{m}^{3}$ of water and the area inundated is about $17 \mathrm{~km}^{2}$, hence the average depth (at maximum filling) is about $5 \mathrm{~m}$.

At the time of construction (2008) the lifetime of the reservoir was estimated at 50 years. Sedimentation due to soil erosion in the catchments was estimated (using the Universal Soil Loss Equation) at $48,000 \mathrm{~m}^{3} \mathrm{y}^{-1}$ with a sediment yield of $3.7 \mathrm{t} \mathrm{ha}^{-1} \mathrm{y}^{-1}$ (MoWR, 2008). However, recent studies show that the reservoir is losing its storage volume at a much faster rate. For instance, Assefa et al. (2015) estimated at $84,800 \mathrm{~m}^{3} \mathrm{y}^{-1}$ with a sediment yield of $6.0 \mathrm{t} \mathrm{ha}^{-1} \mathrm{y}^{-1}$; Reynolds (2013) estimated at 700,000 $\mathrm{m}^{3} \mathrm{y}^{-1}$ with a sediment yield of $55 \mathrm{t} \mathrm{ha}^{-1} \mathrm{y}^{-1}$; and Yeshaneh et al. (2014) estimated at $269,000 \mathrm{~m}^{3} \mathrm{y}^{-1}$ with a sediment yield of $26 \mathrm{tha}^{-1} \mathrm{y}^{-1}$. 
So, in spite of massive investments in soil conservation measures in the catchments, the reservoir lifetime is threatened by sedimentation. Rapid water storage loss due to sedimentation is becoming an important factor undermining the sustainable use of the reservoir. Figure 1.2 shows Koga reservoir with dark brown colour due to high suspended sediment concentration.

The reservoir represents an important economic value in the area. It can irrigate about 7,000 ha of land and benefit about 14,000 farmers living downstream of the reservoir. Currently farmers are producing fruits, crops and vegetables two or more times per year. Maize, potato, green pepper, cabbage, garlic, onion, tomato, carrot and beetroot are the main products largely produced by farmers from Koga irrigated agriculture.

The urban population of Merawi and Wetet Abay (the nearest towns) with an estimated population of 15,000 and large number of people living in Bahir Dar, the capital city of Amhara Regional State, are also benefiting from the irrigation infrastructure.

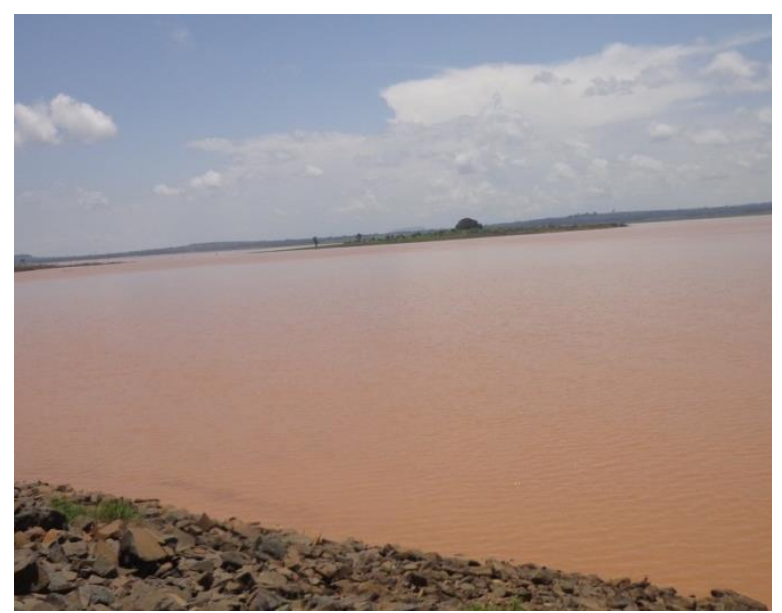

Figure 1.2 Koga reservoir with dark brown coloured water due to high suspended sediment concentration

The soil conservation measures that were constructed in the catchments were aiming at reducing sheet erosion by reducing the erosive power of overland flow due to runoff. Runoff is reduced by increasing infiltration and runoff speed is reduced by reducing slope length. So, considerable effort was made to implement soil bund and fanya juu ridges (reducing slope length) and micro-trench structures (increasing infiltration). Over $144 \mathrm{~km}$ of soil/stone bunds and fanya juu ridges and >576 micro-trenches were constructed within Minizr catchment alone.

Apparently, the current approach to soil conservation is not sufficient to reduce the sediment load reaching the reservoir. This is the problem addressed in this thesis.

\subsection{Scientific objective}

The general objective of this study was to evaluate the sediment load at Koga reservoir and if that load is considered too high to design measures to lower that load. 
Although authorities are concerned about the life time of Koga reservoir, available data on sediment load, as presented in the introduction (Section 1.1) are not consistent. Hence before we can design effective measures, we have to evaluate current sedimentation into the reservoir.

Parts of Koga catchment has received a lot of assistance in on-site physical soil conservation measures like fanya juu, soil bund and micro-trenches. The questions is how effective this investment has been in retarding sediment load into Koga reservoir.

Besides these more-or-less standard on-site physical soil conservation measures there maybe biological measures or off-site measures that are more effective. A specific challenge for the Koga system is that it contains a wetland and a floodplain and that we know very little of their function in relation to sediment trapping. These questions call for a firm literature study and depending on its outcome on some real-world experimentation with alternative (in the sense that they are yet unknown in the area) measures.

Finally the 'spatial' question should be raised. With a wide choice of measures, both physical and biological and on-site as well as off-site options there is a need for a kind of optimization in space. In other words, where to apply what?

\subsection{State of the art}

On-site soil erosion and off-site sedimentation are natural phenomena in landscape formation. However, human activities have accelerated natural erosion rates causing on- and off-site problems with soil degradation and sediment accumulation in undesirable locations (reservoirs, rivers, etc.). Human induced off-site sedimentation is the product of on-site soil erosion resulting either from point sources like mining and construction sites or non-point sources such as from agricultural areas and grazing lands.

In Ethiopia, rates of soil erosion are alarmingly high and sedimentation in reservoirs, lakes, and rivers is a serious problem (Haregeweyn et al., 2006; Tamene et al., 2006a). Many reservoirs which have been established for hydroelectric power, urban water supply and irrigation accumulate large amounts of sediment, resulting in shortage of water supply for these functions and decline in reservoirs water storage capacity. Some of the dams in the Amhara region of Ethiopia, like the dams of Adrako, Borkena and Dana (Amare, 2005; Kebede, 2012) have completely silted up before their design expectation period. Other dams in this region that have been constructed over the last decades are threatened by accelerated sedimentation.

Until recently, most studies and development activities that aim at reducing the sediment load in the reservoirs were focused on on-site soil and water conservation (SWC) measures on agricultural areas in the catchment. Off-site soil conservation measures is largely disregarded. Many technical and socioeconomic opportunities were documented but adoption by farmers and actual improvements in the field are limited. In addition, such SWC measures are never designed to eliminate sediment loss and transport completely. In its best, these measures reduce soil loss till a Tolerable Soil Loss level. Hence, there will always be drainage out of a catchment that is loaded with some sediment. 
According to Walling (2006), although on-site soil conservation measures result in reduced catchment sediment yields, sediment trapped by dams at the outlets of sub-catchments represent the dominant cause of reduced catchment sediment yields. Sediment storage dams (SSDs) are best examples, which have been implemented by the Ethiopian government in the Amhara region over the last decades. According to MERET (2008), one possible way to trap sediment in the sediment cascade is using SSDs to be built at the outlets of sub-catchments within the larger catchment. However, their efficacy in trapping sediment is not well known.

Natural sediment sinks, that include wetlands, floodplains and grassed waterways, are important offsite sediment trapping (ST) features. For example, in southwest France, floodplain sediment deposition rates ranged from 0.02 to $75 \mathrm{~kg} \mathrm{~m}^{-2} \mathrm{y}^{-1}$ (Brunet \& Astin, 2008) and the Imperial Valley wetland in California, USA showed a STE of 97\% (Kadlec et al., 2010). Even though floodplains and wetlands cover large areas in Ethiopia, especially bordering natural lakes and man-made reservoirs, their role in trapping the inflow sediment coming from the surrounding land and thus reducing rate of sedimentation is not well studied.

Vegetative ST measures (like grass barriers) can play a significant role in trapping sediments from overland flow by decreasing the speed and erosive potential of runoff water (Blanco-Canqui et al., 2006). Although different studies had been conducted and information is available on the performance of such vegetative measures, especially in North America and Europe, there is a scarcity of quantitative information for tropical regions. Many grass species that could potentially serve as vegetative barriers have not been studied for their sediment trapping efficacy (STE), including the locally used grass species in the north-western Ethiopian highlands, Desho (Pennisetum pedicellatum), Senbelet (Hyparrhenia rufa), Sebez (Pennisetum schimpri) and Akirma (Eleusine floccifolia). Such local grass species may have better sediment trapping performance than the known ones. Therefore, instead of introducing and using vegetative species from other areas, evaluating the locally dominant and available species for their STE and using them is urgent.

To design and implement appropriate ST measures within a catchment and reduce sediment transport to downstream reservoirs, detailed information on the temporal and spatial distribution of erosion events and sediment source areas is essential (Herweg \& Stillhardt, 1999; Mekonnen \& Melesse, 2011). According to Verstraeten et al. (2003), to implement relevant sediment management measures within an upstream catchment, it is crucial to realize the severity of the sedimentation problem and the major factors controlling it.

Different approaches exist to estimate surface runoff, soil erosion and sediment yield from a catchment including models (Mekonnen \& Melesse, 2011; Keesstra et al., 2014a), sediment rating curves and river samplings (Yeshaneh et al., 2014), bathymetric surveys (Tamene et al., 2006a) and trapped sediment analysis (Baade et al., 2012; Stefanidis \& Stefanidis, 2012). Each approach has its advantages and disadvantages in relation to data requirement and availability, easiness for application and cost effectiveness. An approach requiring minimal and easily accessible input datasets and is cost effective, is the best approach in data scarce countries like Ethiopia. 


\subsection{Research hypothesis and research questions}

Our hypothesis is that erosion can never be stopped sufficiently in NW Ethiopia and that on-site and off-site ST measures are needed to reduce the sediment load into valuable reservoirs till a safe level.

In other words, not all efforts should focus on soil conservation, but also on the safe routing of sediment-laden flows and on creating sites and conditions where sediment can be trapped, preferably in a cost effective or even profitable way.

Measures that promote sedimentation within farmers' fields are called 'on-site' measures and those outside the sphere of influence of individual farmers' fields are 'off-site' measures. On-site ST measures reduce overland flow velocity and thereby retard sediment in transport, resulting in sediment deposition within fields before sediment can be discharged into streams. Off-site ST measures reduce concentrated runoff velocity within (ephemeral) gullies and the river channel system thereby enhancing infiltration of water and deposition of sediment.

Integrated sediment trapping at catchment scale, which is implementing all possible on-and off-site ST measures at the required locations within the catchment, is assumed to reduce land-scape connectivity, enhance ST (sediment trapping/deposition) within the catchment and decrease sediment discharge at the outlet of a catchment.

To this end, the following research questions have been formulated dealt with in separate chapters

1 Is Minizr catchment an important source of sediment for Koga reservoir? If so, how much is the sediment load? Is there spatial and temporal variation? (Chapter 2).

2 What is the best method or approach to be used while implementing ST measures within a catchment, which helps to reduce sediment in transport to downstream reservoirs? (Chapter 3).

3 Are the locally dominant indigenous grass species in northwest Ethiopia (Desho, Senbelet, Akirma and Sebez) effective in trapping sediment from agricultural fields? What are the key functional traits, which will play a great role for ST? How much of the inflow sediment trapped by the grass barriers, with what STE? (Chapter 4).

$4 \quad$ How much sediment can be trapped by sediment storage dams? With what STE? Are they economically feasible for the small-scale farmers' in Ethiopia? (Chapter 5).

5 How much sediment is trapped by the existing physical ST measures, with what STE? How much sediment is trapped by natural sediment sinks, with what STE? Are man-made and natural sediment sinks reducing the Koga reservoir sediment load? (Chapter 6).

6 Is it possible to use a landscape model (LAPSUS_D) in the northwest Ethiopian highlands to help with integrated sediment trapping at catchment scale by optimizing the use of ST measures? (Chapter 7).

\subsection{Research design}

\section{Study area}

The study was conducted in the Minizr catchment in the North-western highlands of Ethiopia (UTM 1255891 - 1249499 N; 303559 - 310272 E; Adindan_UTM_Zone_37N, Figure 1.3) which is a source of 
water for the Koga reservoir. It covers an area of $20 \mathrm{~km}^{2}$ with an elevation range of $2035 \mathrm{~m}$ at the outlet to 2283 m.a.s.l. at its highest point on the watershed divide. Slopes in the catchment range from $0-51 \%$ (average of $8 \%$ ), while $>80 \%$ of the catchment has slopes between $0-8 \%$.

Land use within the catchment area includes $71 \%$ farmland, $18 \%$ grazing land, while plantation, bush land and settlement areas account for the remaining 11\%. Average rainfall (2013-2015) was 1215 $\mathrm{mm} \mathrm{y}^{-1}$, which falls mainly between June to September, and is preceded and followed by one month of sporadic, low intensity rain. Average minimum and maximum temperatures are $11^{\circ} \mathrm{C}$ and $26^{\circ} \mathrm{C}$. Based on FAO classification system, dominant soil types are Nitosols (62\%), Eutric Vertisols (30\%), Lithic Leptosols (6\%) and Chromic Cambisols (2\%) (MNREP, 1995).

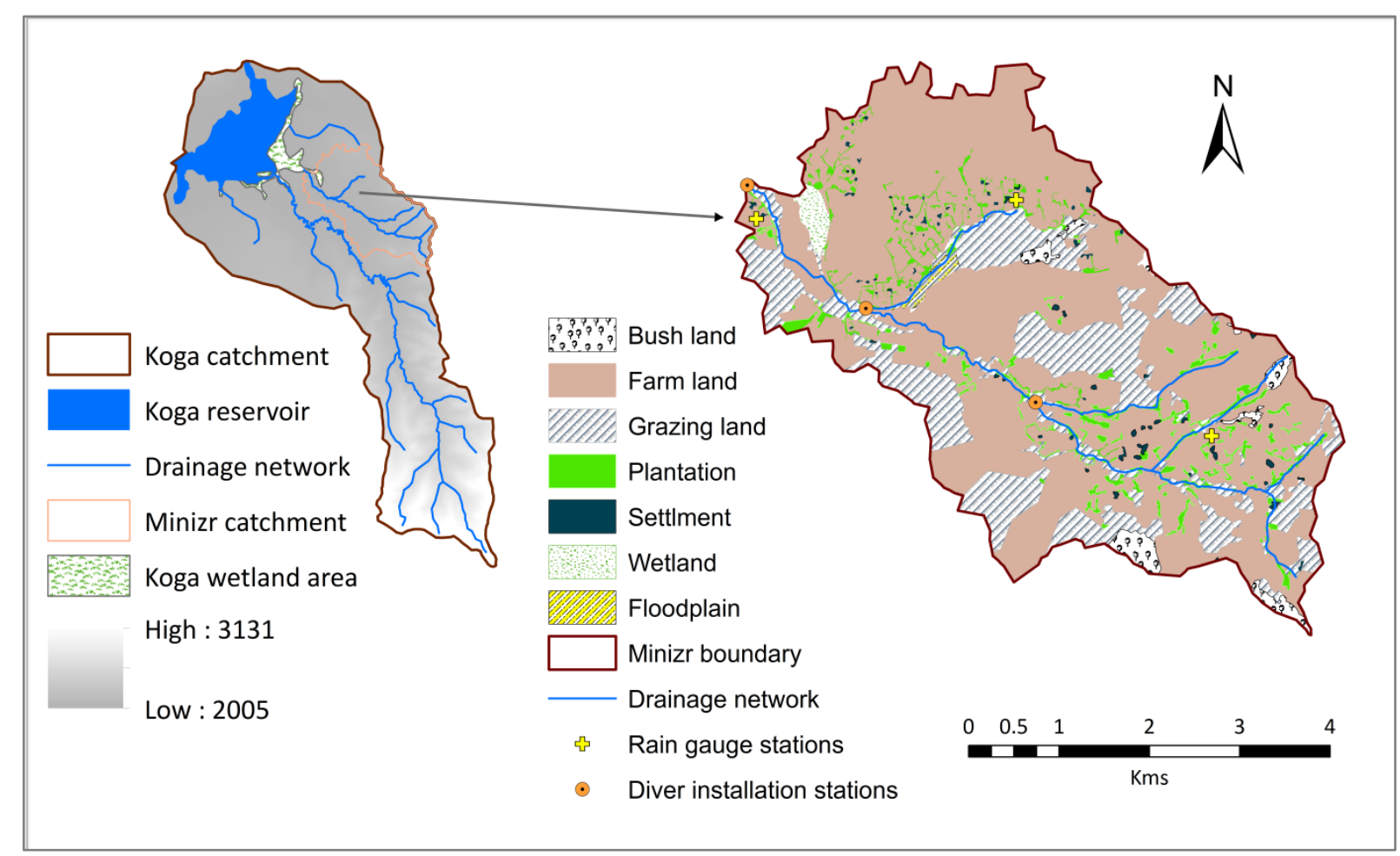

Figure 1.3 location map of the study area showing Koga reservoir, Koga and Minizr catchments, rainfall and runoff-sediment discharge monitoring stations

\section{Datasets and mapping}

Satellite images; SPOT $5 \mathrm{~m}$ and Google Earth $0.6 \mathrm{~m}$ resolutions, were used to prepare land use / land cover; to digitize and quantify the lengths of physical ST structures (soil bunds and Fanya Juu); to identify and map natural sediment sinks (wetland, floodplain and grassed waterways); to delineate areas affected by gully erosion and gully dimensions; and to digitize and determine the lengths of sediment transfer pathways. A topographic map 1:50,000 scale (EMA, 1987) was used to delineate the boundaries of sub-catchments and their drainage networks. A Digital Elevation Model (ASTER DEM $30 \mathrm{~m}$; 2009) was used to derive the elevation and slope characteristics. GPS (Garmin GPS 60, 2 $\mathrm{m}$ accuracy) was used to collect track line of sediment pathways, catchment pour points, diver and rain gauge installation stations. Detailed descriptions of the datasets and mapping procedures were given in each chapter. 


\section{Data collection methods and analysis}

The data collection methodologies used in this research were intensive field survey and observation, interviewing stakeholders, a comprehensive literature review of scientific journal articles, multilocation field experiments, runoff and sediment yield modelling, field level primary data measurements, Satellite Imagery and DEM analysis. Data analysis was done using excel; IBM SPSS statistics 22 software; a daily resolution runoff and sediment yield model, LAPSUS_D and ArcGIS 10.2.1 spatial analyst. A hydrometer method was used for texture analysis. Each of the data collection and analysis methods have been described in each chapter.

\subsection{Definition of terms and concepts}

According to ISSS (1996), a catchment/watershed is defined as the area which supplies water by surface and subsurface flow from rain to a given point in the drainage system.

A vegetative ST measure is a band of growing vegetation (trees or grasses) across the slope, to slow runoff, increase infiltration, and cause sediment to be deposited. A grass strip/barrier is a band of grass laid out on cultivated land along the contour to trap sediment in transport.

Structural ST measures are embankments across the slope, to slow runoff, increase infiltration, and cause sediment to be deposited (For example soil/stone bunds, micro-trenches).

Critical sediment source areas or erosion hotspots are parts of the catchment with high erosion rates and high sediment transport capacities (McDowell \& Srinivasan, 2009; Mekonnen \& Melesse, 2011) while sinks are areas of infiltration and sedimentation, which lower hydrological connectivity and decrease the area-specific runoff and sediment yield (Lesschen et al., 2009).

Sediment storage dams are physical structures or barriers built of stone, gabion or concrete and located within large sized and deep gullies or inside temporary river channels to trap sediment (MERET, 2008).

Soil/stone bund is an embankment along the contour, made of soil and/or stones, with a basin at its upper side to reduce or stop overland flow and its effect in causing erosion (Hurni, 1986).

According to Bracken et al. (2015) sediment connectivity can be used to explain the continuity of sediment transfer from a source to a sink in a catchment that occurs via transport vectors (e.g. water, wind, glaciers, gravity, animals).

Verstraeten and Poesen (2000) defined sediment trapping efficacy (STE) as the proportion of the incoming sediment that is deposited, or trapped, in a reservoir or behind sediment trapping measures (check dam /sediment storage dams or grass barriers or SWC structures).

Integrated sediment trapping can be defined as implementing all required sediment trapping measures at the most appropriate spatial locations within a catchment to decrease runoff velocity and sediment transport and thus increase sedimentation. Integrated sediment trapping focuses on 
technological integration as part of an integrated catchment management approach (MOARD, 2005), which is integrating sectors, systems, technologies, resources, etc within a catchment to solve natural resource degradation and other related problems (like health and education) focusing on community participation.

A wetland is a lowland area, such as a marsh or swamp, that is saturated with moisture (American Heritage Dictionary, 2011).

A floodplain a nearly flat plain area along the course of a stream or river that is naturally subject to flooding (Goudie, 2004).

\subsection{Conceptual framework and thesis outlines}

This thesis consists of eight chapters. The introductory chapter describes the problem statement, scientific objectives, state of the art, research hypothesis, specific research questions, research design and definition of key terms.

Chapters 2 to 7 build on each other and form together the conceptual framework of this thesis (Figure 1.4). Most chapters are based on scientific papers that have been published or have been submitted to peer reviewed journals, all of which are stand alone and independent.

Chapter 2 attempts to estimate the sediment load and take away the uncertainty of the amount of sediment entering Koga reservoir. Intensive field measurements took place for three years (20132015). This provides insight in the spatial and temporal variations of sediment load within the catchment. The role of sediment transfer pathways density on landscape connectivity and sediment yield is also evaluated.

Chapter 3 investigates what is already known about sediment trapping measures. It presents an overview on the sediment trapping efficacy (STE) of physical and vegetative sediment trapping (ST) measures at global scale, reviewing more than 90 scientific journal articles, case studies, government reports, conference proceedings and book chapters. In addition there are participatory field observations and stakeholders' interviews.

This review leads to three promising directions of research. Since we can expect effective sediment trapping using grass strips we evaluated a number of species in a field trial described in Chapter 4. Since we found that drainage channels, gullies and footpaths are main sediment transfer pathways, sediment dams are also considered an interesting option which we investigated in Chapter 5. Finally it is worthwhile to know the trapping efficacy of existing man-made soil and water conservation structures in the catchment such as soil bunds, fanya juu and micro-trenches (Chapter 6). The same holds for the existing natural sediment sinks like the floodplain, the wetland and different waterways.

Chapter 7 tries to identify the best approach for implementing a combination of sediment trapping measures within the Minizr catchment using the daily resolution LAPSUS_D model. 
The final chapter is a synthesis of previous chapters. It not only summarizes the main results but also discusses the scientific value of the thesis and its limitations. Furthermore attention is given to recommendations for policy, extension and further research.

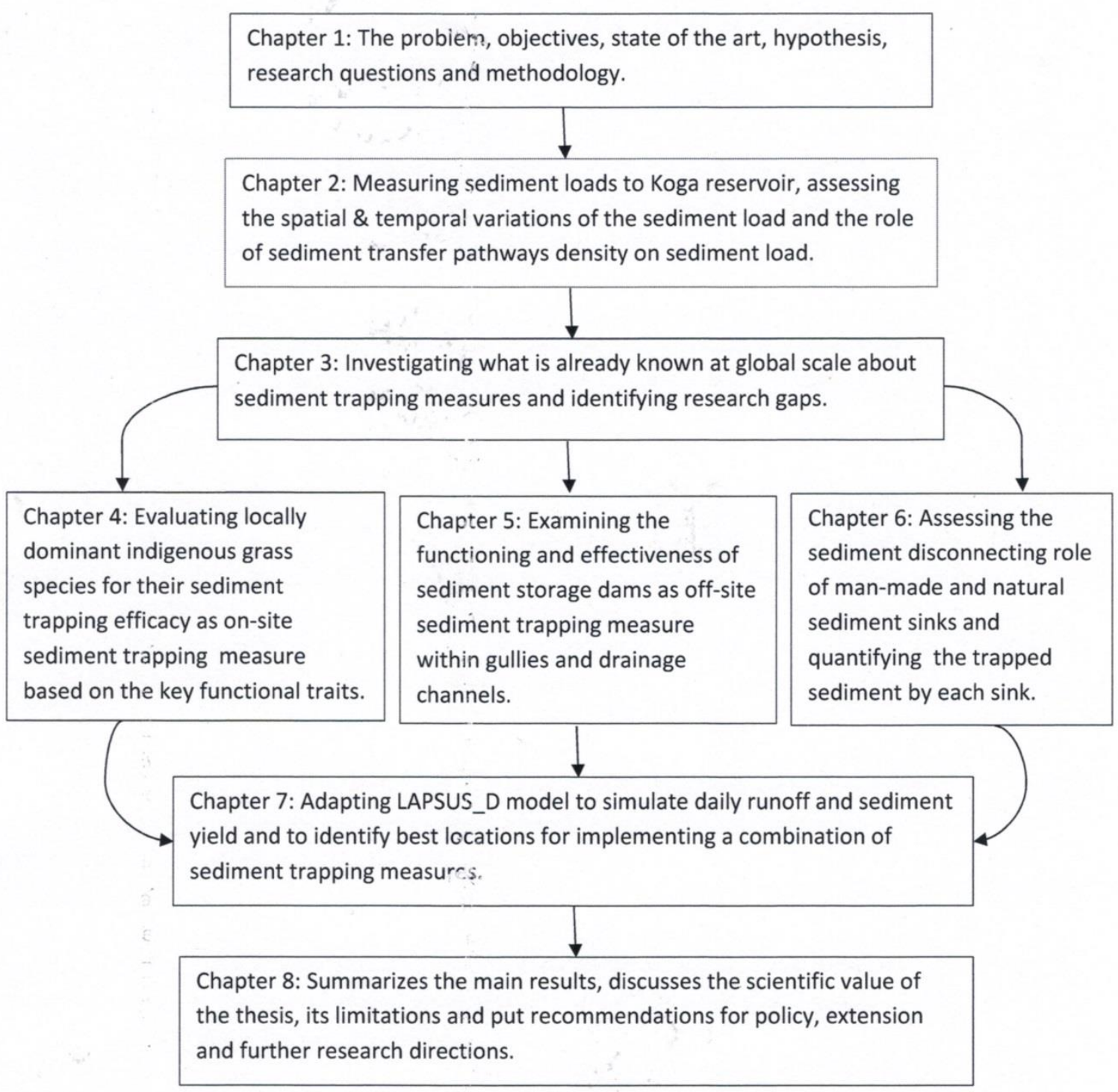

Figure 1.4 Conceptual framework of the thesis 


\section{Chapter 2}

\section{Spatial and temporal variations of sediment entering Koga reservoir, NW Ethiopia}

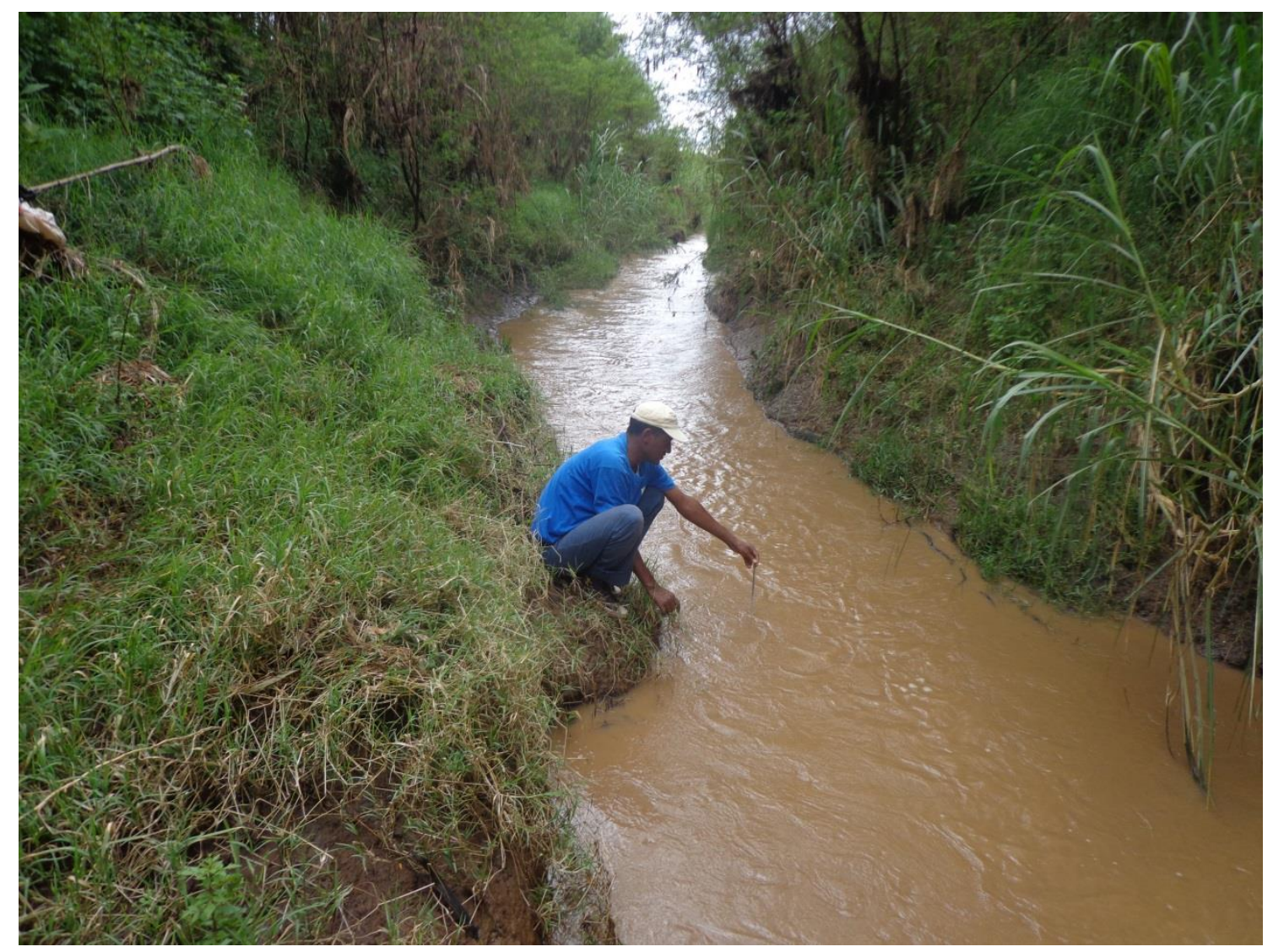

This paper is submitted as:

Mulatie Mekonnen, Saskia D. Keesstra, Jantiene EM Baartman, Leo Stroosnijder, Rens JH Masselink. Spatial and temporal variations of sediment entering Koga reservoir, NW Ethiopia.

Earth Surface Processes and Landforms 


\section{Spatial and temporal variations of sediment entering Koga reservoir, NW Ethiopia}

Abstract

Soil erosion within a catchment does not only remove the soil but also reduces the water storage capacity of downstream reservoirs because of sedimentation. In Ethiopia, this is a major problem in many reservoirs, including the Koga reservoir in NW Ethiopia. This study was conducted in Minizr catchment to quantify the amount of sediment entering Koga reservoir, to identify potential sediment source areas at sub-catchment scale, to assess temporal variation in sediment production on daily, monthly and yearly basis and to identify sediment transfer pathways (STPS), which could enhance sediment connectivity and facilitate sediment transport. Insight herein could help to intervene the siltation problem of the reservoir. To collect runoff and sediment discharge data, three hydrological monitoring stations, each consisting of a pressure transducer (diver) and staff gauge were installed both at the outlet of the main catchment above the reservoir and at the outlets of two sub-catchments. Data was collected at the outlet of the main catchment for three years (20132015) and at the outlet of the sub-catchments for two years (2014-2015). Results show that on average 43,000 $t\left(21.5 t_{h a^{-1}}\right)$ sediment entered Koga reservoir annually. Midre-Genet sub-catchment had the highest density of STPs $\left(4.7 \mathrm{~km} \mathrm{~km}^{-2}\right)$ and gullies, which contributed most to the total sediment measured $\left(19,400 \mathrm{t} \mathrm{y}^{-1}\right)$ followed by Adibera sub-catchment $\left(13,100 \mathrm{t}^{-1}\right)$. Tume-Shafrie sub-catchment with the lowest STPs density and without gullies, contributed the least to the total sediment measured $\left(6,700 t y^{-1}\right)$. Temporally, daily and monthly sediment discharges were highest in July and August. Drainage channels, gullies and footpaths were found to be the main STPs enhancing sediment connectivity and transport. As a result, large amounts of sediment are entering Koga reservoir, which considerably compromise its water holding capacity. Therefore, sediment trapping measures, which helps to trap the sediment, enhance sedimentation within the catchment and disconnect the sediment connectivity functions of the STPS will help to decrease the sediment entering the reservoir.

\subsection{Introduction}

Construction of dams to collect surface water for irrigation, human and animal consumption and electric power generation is carried out at an increasingly fast rate all over the world, resulting in more than 45,000 registered large dams (WCD, 2000; ICOLD, 2007), together storing $\sim 11,000 \mathrm{~km}^{3}$ of water (Chao et al., 2008). However, many dams are seriously threatened by sedimentation and are losing their water storage capacity, with an estimated yearly average of $0.5-1 \%$ (Walling, 2006; Basson, 2008).

Water erosion plays a large role in transporting sediments from upstream catchments to downstream reservoirs. Although any slope, and any place where water flows is potentially a sediment transfer pathway (STP), rivers, gullies and roads are important STPs (Poesen et al., 2003; Morgan, 2005; Bracken et al., 2015). An increase in the density of STPs will increase sediment transport while disconnecting STPs reduces sediment transport and increases sedimentability (Fryirs, 
2012; Mekonnen et al., 2016b; Thompson et al., 2016). To study the processes involved in sediment transport over particular pathways, the concept of connectivity was used (Bracken et al., 2015; Parsons et al., 2015; Masselink et al., 2016), which allows studying catchment scale processes in a holistic way. The concept of connectivity works with source areas, STPs and sinks, and tries to identify how processes within these different units in the system interact. Sediment connectivity can be used to explain the (dis)continuity of sediment transfer from a source to a sink in a catchment that occurs via transport vectors (e.g. water, wind, animals) (Bracken et al., 2015).

Disconnecting STPs through efficient sediment trapping (ST) measures could help to increase sediment deposition and reduce downstream sediment loads (Keesstra et al., 2009; Baartman et al., 2013; Mekonnen et al., 2016a; Mekonnen et al., 2016b). Identifying the STPs within a catchment helps to implement ST measures where they can disconnect the STPs to enhance ST (Lloyd et al., 2016). Implementing ST measures at the most appropriate locations where they can disconnect landscape units, is believed to be the most efficient way to reduce reservoir sedimentation (Mekonnen et al., 2014).

Sediment discharge from a catchment is highly variable both temporally and spatially (Hagmann, 1996; Yeshaneh et al., 2014; Buendia et al., 2016), which is because the processes driving catchment sediment dynamics have proved to be highly variable in space and time (Liu et al., 2012). Over recent decades, there has been an increased interest in quantifying sediment loads of intra-annual (within a year) variability in addition to inter-annual (between years) in order to improve understanding of suspended sediment loads at a higher temporal resolution (Smith et al., 2003; Seeger et al., 2004). This increased interest for intra-annual variability arose because it was shown that for many catchments only a small part of the catchment and only a few heavy rain storms on specific dates produced the bulk of annual sediment yield (Hagmann, 1996; Ziadat \& Taimeh, 2013).

Therefore, it is important to have better insights in the spatial and temporal variability of the intraannual sediment budget of a catchment. Where are the sources of the sediment? Are there hotspots of sediment production/sedimentation in the system? Which are the most vulnerable moments in the year that the sediment is transported to the outlet of the system? Insights into these dynamics can help to identify sediment sources, to design improved land management strategies, to reduce sediment production, to decrease sediment transport capacity within the system; and finally, to allow the STPs to pass through areas where the sediment can be trapped (Stroosnijder, 2009; Bracken et al., 2015; Lloyd et al., 2016; Mekonnen et al., 2016b). According to Herweg and Stillhardt (1999) and Mekonnen and Melesse (2011), identifying the critical sediment discharging periods and the respective erosion hotspots producing the sediment are vital to design and implement suitable ST measures.

In Ethiopia, the rates of on-site soil erosion and downstream sedimentation in water reservoirs are alarmingly high (Haregeweyn et al., 2006; Tamene et al., 2006a). Many reservoirs which have been established for hydroelectric power, drinking water supply and irrigation accumulate larger amounts of sediment than expected (Amare, 2005; Kebede, 2012). Koga reservoir is one of the largest reservoirs constructed in the northwest highlands of Ethiopia to collect surface runoff for irrigated 
agriculture. It is constructed at the outlets of Koga and Minizr catchments. It stores up to 83 million $\mathrm{m}^{3}$ of water and can irrigate $\sim 7000$ ha of land. The reservoir is expected to benefit $\sim 14,000$ farmers living below the dam in the irrigation command area to produce crops, vegetables and fruits (MoWR, 2008).

However, the reservoir lifetime is threatened by high sedimentation rates. Figure 2.1 shows the brown, high sediment laden water of the Koga and Minizr rivers, draining into the Koga reservoir. Yeshaneh et al. (2014) found that the upper part of Koga catchment $\left(\sim 98 \mathrm{~km}^{2}\right)$ alone contributed $\sim 252000 \mathrm{t} \mathrm{y}^{-1}\left(25.6 \mathrm{t} \mathrm{ha}^{-1} \mathrm{y}^{-1}\right)$ of sediment to the Koga reservoir. Sediment yield from the other contributing catchment, the Minizr catchment, has not been measured yet. The Minizr catchment has characteristics that differ from the upper Koga catchment in terms of topography, soil type and land management interventions. In addition, the Minizr catchment has natural sediment sinks like a wetland and a floodplain which can play an important role in disconnecting the STPs and trapping sediment (Mekonnen et al., 2016c).

Therefore, the main objectives of this study in the Minizr catchment, northwest Ethiopia were to: (i) estimate the sediment entering Koga reservoir from Minizr catchment and evaluate its temporal (daily, monthly and yearly) and spatial (sub-catchment scale) variation and (ii) identify potential STPs and evaluate their role on the spatial variations of sediment discharge for sediment control measures using the concept of connectivity.
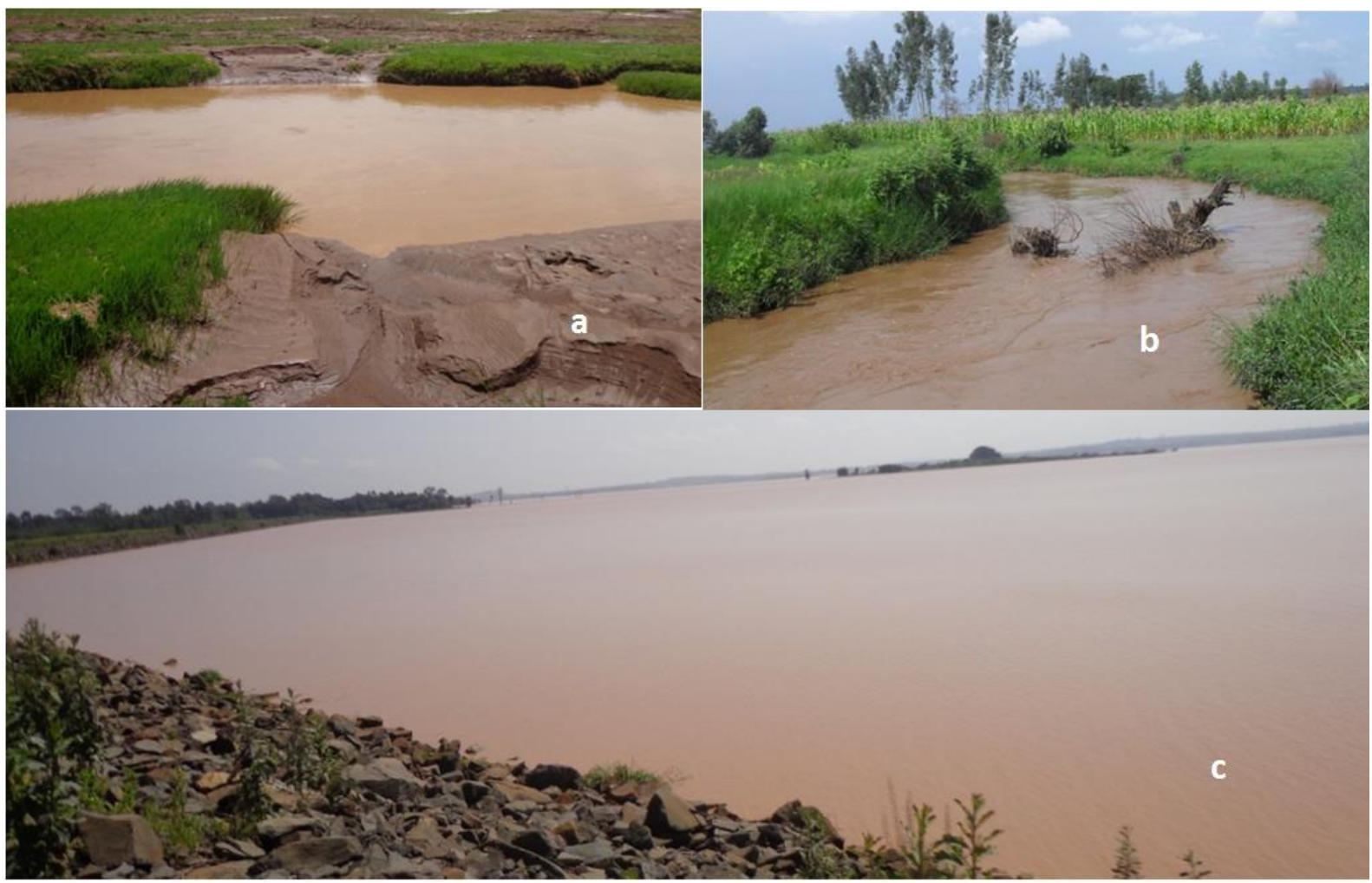

Figure 2.1 Examples of high suspended sediment loads in the Minizr (a) and Koga (b) rivers. These rivers both drain into the Koga reservoir (c) (photo by Mulatie Mekonnen, 2012) 


\subsection{Materials and methods}

\section{Study area}

The study was conducted in the Minizr catchment in the North-western highlands of Ethiopia (UTM 1255891 - 1249499 N; 310272 - 303559 E; Adindan_UTM_Zone_37N, Figure 2.2) which is an important source of water for the Koga reservoir. It covers an area of $20 \mathrm{~km}^{2}$ with elevation ranging between $2035 \mathrm{~m}$ at the outlet to $2283 \mathrm{~m}$.a.s.l. at its highest point on the watershed divide. Slopes in the catchment range from $0-51 \%$ with a mean slope of $8 \%$. More than $80 \%$ of the catchment has slopes between $0-8 \%$.

Land use within the catchment area includes $71 \%$ farmland, $18 \%$ grazing land, while plantation, bush land and settlement areas account for the remaining 11\%. Mean annual rainfall (2013-2015) is 1215 $\mathrm{mm}$, which falls mainly as high intensity rainfall from June to September, and is preceded and followed by one month of sporadic, low intensity rain. Average minimum and maximum daily temperatures are $11^{\circ} \mathrm{C}$ and $26^{\circ} \mathrm{C}$, respectively. Dominant soil types are Nitosols (62\%), Eutric Vertisols (30\%), Lithic Leptosols (6\%) and Chromic Cambisols (2\%) (MNREP, 1995). Table 2.1 shows the slope, elevation and dominant soil types of the sub-catchments of the Minizr catchment.

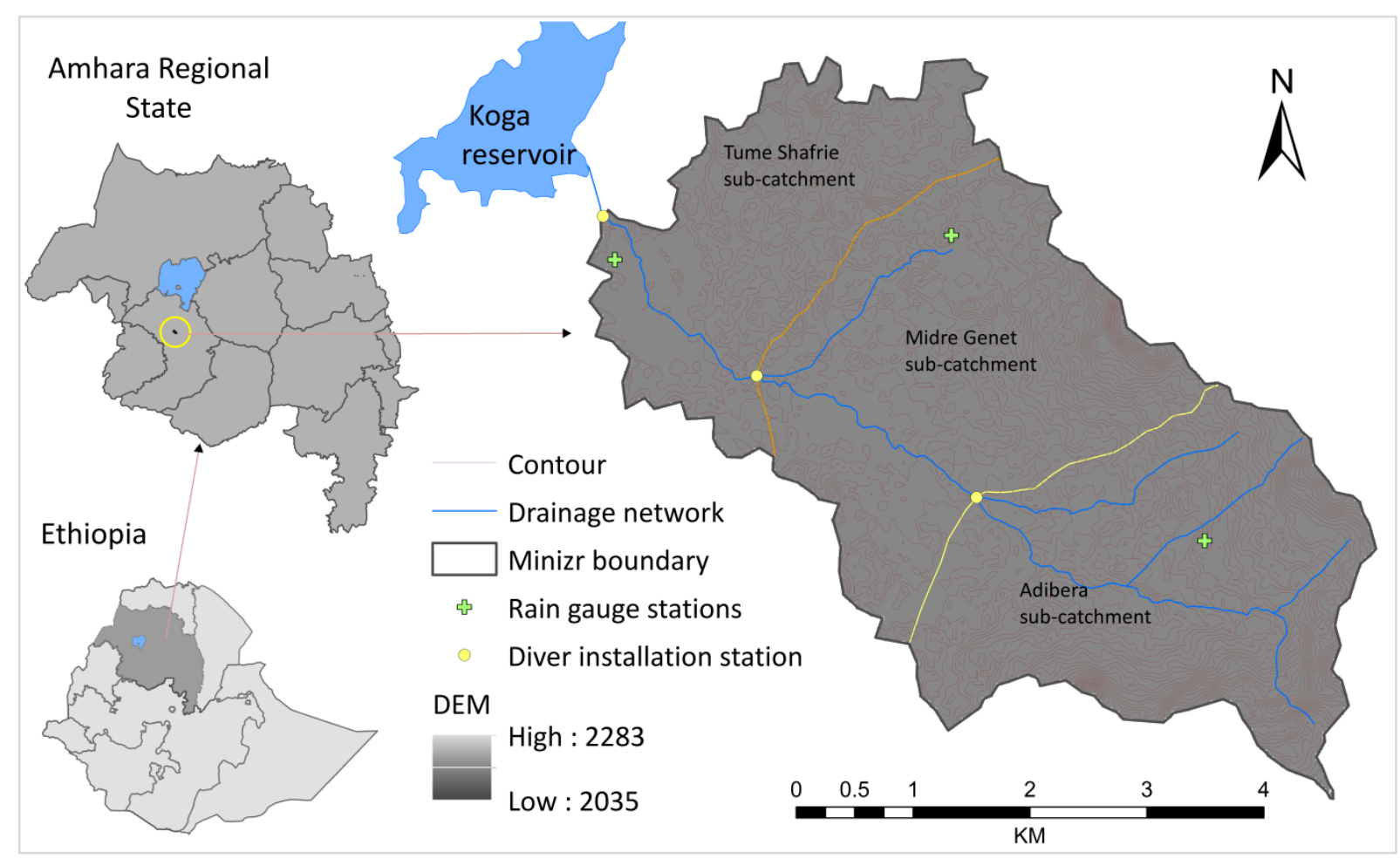

Figure 2.2 Location map of Minizr with sub-catchments, rain gauge and diver installation stations.

\section{Mapping}

A Digital Elevation Model (ASTER DEM $30 \mathrm{~m}$; 2009) was used to delineate Minizr catchment using an automatic delineation method and to generate slope and elevation characteristics. A topographic 
map 1:50,000 scale (EMA, 1987) was used to delineate the boundary of each sub-catchment (Adibera, Midre-Genet and Tume-Shafrie). ArcGIS 10.2.1 software was used for mapping and a GPS (Garmin 60, $\sim 2 \mathrm{~m}$ accuracy) was used to indicate locations of rain gauge and diver installation stations and to collect pour points of the catchment outlets. Moreover, GPS helped to track STPs and accurately digitize them on Google map.

\section{Estimating runoff}

To collect runoff and sediment discharge data, three hydrological monitoring stations consisting of pressure transducers (divers) and staff gauges were installed at the outlet of the main Minizr catchment and at the outlets of two sub-catchments, Adibera and Midre-Genet (Figure 2.2). The data collection station for the third sub-catchment, Tume-Shafrie, was at the same location as the main catchment because they have the same outlet. The monitoring stations were established on relatively stable and steep cross sections with uniform water flow and channel dimensions.

Table 2.1 area coverage, average slope, elevation and dominant soil types of the Minizr sub-catchments

\begin{tabular}{|c|c|c|c|c|c|}
\hline $\begin{array}{l}\text { Sub- } \\
\text { catchments }\end{array}$ & $\begin{array}{l}\text { Position within the } \\
\text { main catchment }\end{array}$ & Area (ha) & $\begin{array}{l}\text { Average slope } \\
\text { (\%) }\end{array}$ & Elevation $(\mathrm{m})$ & $\begin{array}{l}\text { Dominant } \\
\text { soil type }\end{array}$ \\
\hline Adibera & Upstream & 780 & 10 & $2059-2283$ & Nitosols \\
\hline Midre-Genet & Middle & 760 & 7.5 & $2049-2221$ & Vertisols \\
\hline Tume-Shafrie & Lower/outlet & 500 & 7 & $2035-2127$ & Nitosols \\
\hline
\end{tabular}

Stream water level was monitored continuously at the outlet of the main catchment for three years (2013-2015) and at the outlets of the two sub-catchments for two years (2014-2015) with a temporal resolution of 15 minutes during the rainy seasons. Stream channel width was measured directly in the field using tape meter. River flow velocity $\left(\mathrm{m} \mathrm{s}^{-1}\right)$ was measured using the Valeport 'Braystoke' Model 001 current meter at different water depths. During peak flow, we measured the flow velocity at $10 \mathrm{~cm}$ intervals, starting from the peak until the water height reached its minimum. This measurement was done three times and the mean value was considered for each height. Runoff discharge $\left(\mathrm{m}^{3} \mathrm{~s}^{-1}\right)$ was then calculated using Eq. 2.1 multiplying the channel width $(\mathrm{m})$, water depth $(\mathrm{m})$ and river flow velocity $\left(\mathrm{m} \mathrm{s}^{-1}\right)$ (FAO, 1993). The measured discharges in $\mathrm{m}^{3} \mathrm{~s}^{-1}$ were converted to daily discharge $\left(\mathrm{m}^{3}\right.$ day $\left.{ }^{-1}\right)$. Daily runoff discharges were summed up to find monthly and annual discharges.

$\mathrm{Qw}=\mathrm{A} * \mathrm{~V}$

Where, $Q w$ is discharge in $\mathrm{m}^{3} \mathrm{~s}^{-1} ; \mathrm{A}$ is channel cross sectional area $\left(\mathrm{m}^{2}\right)$ and $\mathrm{V}$ is flow velocity $\left(\mathrm{m} \mathrm{s}^{-1}\right)$

\section{Estimating sediment discharges}

Sediment entering Koga reservoir from Minizr catchment was calculated from suspended sediment concentration samples and Eq. 2.2 (McGregor \& Cook, 2006; Blanchard et al., 2011). Daily measured suspended sediment concentration was used without developing a rating curve since the daily 
collected data was considered more representative. A one-litre suspended sediment sample was collected every day during the rainy seasons of 2013-2015. The staff gauges were used to follow the change in the water level that helped to collect suspended sediment samples when changes in water level occurred. If water level changed significantly during a day due to heavy rainfall, two or more sediment samples were collected per day at different river water flow heights. These samples were then mixed and a one-litre sub-sample was taken for further analysis. A total of 411 one-litre samples (137 in year 2013; 141 in year 2014; and 133 in year 2015) were collected at the outlet of the main catchment. The collected samples were oven dried at $105^{\circ} \mathrm{C}$ for 24 hours and the dry sediment mass was used to calculate suspended sediment concentration $\left(\mathrm{g}^{-1}\right)$. Daily sediment discharge $\left(\mathrm{t} \mathrm{day}^{-1}\right)$ was calculated using Eq. 2.2 by multiplying the estimated daily water discharge $\left(\mathrm{m}^{3} \mathrm{~s}^{-1}\right.$, see above) and the suspended sediment concentration $\left(\mathrm{gl}^{-1}\right)$ measured for that same day. Daily discharges were summed up to find monthly and annual discharges.

$$
Q s=Q w * C s * K
$$

Where, Qs is sediment discharge $\left(t\right.$ day $\left.^{-1}\right)$; $Q w$ is water discharge $\left(\mathrm{m}^{3} \mathrm{~s}^{-1}\right)$; Cs is concentration of suspended sediment $\left(\mathrm{gl}^{-1}\right)$ and $\mathrm{K}$ is 86.4, which is a coefficient to express Qs in $\mathrm{t} \mathrm{day}^{-1}$.

\section{Identifying sediment source areas}

Within a large catchment, sediment source areas can be identified using e.g.: (i) erosion models (Van Rompaey et al., 2001; Mekonnen \& Melesse, 2011; Keesstra et al., 2014b), (ii) suspended sediment discharge measurements at the outlets of sub-catchments (Syvitski \& Milliman, 2007; Yeshaneh et al., 2014) and (iii) field survey methods during and after rainstorms (Bewket \& Sterk, 2003; Zegeye et al., 2010).

In Minizr catchment the spatial variation in sediment production was assessed dividing the larger catchment into sub-catchments and measuring suspended sediment discharge at the outlets of each sub-catchment (see above, estimating sediment discharge). We classified Minizr catchment into 3 sub-catchments (Figure 2.2).

\section{Identifying sediment transfer pathways}

With the advent of high resolution satellite imagery, sediment transfer pathways (STPs) can be identified and studied (Otto et al., 2009). We identified major STPs such as rivers, footpaths and gullies and observed their sediment transport function during an intensive field survey with GPS walks. Sample GPS tracks were collected following STPs which aids in identifying and digitising them from the satellite imagery. Lengths of STPs were digitized and quantified from Google Earth (Quick bird) Imagery using Arc GIS 10.2.1. To check location accuracy, overlaying (layering GPS shape files over digitized shape file) was applied. STPs density was calculated by dividing the total STPs length by the catchment area.

Gullies are not only STPs but also sources of sediment influencing catchment sediment yield. In southern New South Wales for the Warragamba catchment, for instance, sediment yields from gullied catchments of 29, 52, and 510 ha were at least one order of magnitude higher than for un- 
gullied catchments (Armstrong \& Mackenzie, 2002). In this study, gully affected land was quantified using Google Earth Satellite Imagery and GPS. GPS tracks made around gully affected lands were used for verification while digitizing gullies on the image. Moreover, four gullies were selected before the start of the rainy season and their change in dimension (length, width and depth) was measured at the end of the rainy season and the volume $\left(\mathrm{V}, \mathrm{m}^{3}\right)$ of sediment generated was calculated using Eq. 2.3.

$V=(L 2 * A 2)-(L 1 * A 1)$

Where $L 2$ is newly developed gully length $(m)$; $L 1$ is gully length $(m)$ before development; A2 newly developed gully area $\left(\mathrm{m}^{2}\right)$ and $A 1$ is gully area $\left(\mathrm{m}^{2}\right)$ before development.

\subsection{Results}

\section{Runoff and sediment discharges}

On average $\sim 43,000 \mathrm{t}$ of suspended sediment and $\sim 4,500,000 \mathrm{~m}^{3}$ runoff is entering Koga reservoir annually (Table 2.2). In area specific terms, mean sediment yield was $21.5 \mathrm{t} \mathrm{ha}^{-1} \mathrm{y}^{-1}$, varying from 17$27 \mathrm{t} \mathrm{ha}^{-1} \mathrm{y}^{-1}$. Highest annual sediment discharge was recorded in 2013 and lowest sediment discharge in 2015, which corresponds to rainfall amounts, which were also highest in 2013 and lowest in 2015. Annual rainfall amount and runoff, and runoff and sediment discharges showed a good relationship with the coefficient of correlation $\left(R^{2}\right)=0.94$ and $\left(R^{2}\right)=0.95$, respectively.

Table 2.2 Annual runoff and sediment entering Koga reservoir from Minizr catchment (2013-2015)

\begin{tabular}{lllll}
\hline year & Rainfall $(\mathrm{mm})$ & Runoff $\left(\mathrm{m}^{3}\right)$ & Sediment $(\mathrm{t})$ & Sediment yield $\left(\mathrm{t} \mathrm{ha}^{-1} \mathrm{y}^{-1}\right)$ \\
\hline 2013 & 1,431 & $5,820,000$ & 54,000 & 27.0 \\
2014 & 1,269 & $4,424,000$ & 39,700 & 20.0 \\
2015 & 944 & $3,267,000$ & 34,900 & 17.5 \\
\hline
\end{tabular}

The largest amount of sediment entering Koga reservoir within one month was recorded in July $(14,900 \mathrm{t})$, followed by August (12,300 t) (Table 2.3). From the total sediment entering Koga reservoir, 63\% was transported in July and August. Runoff discharge showed an increasing trend from May to September and reduced in October. July showed the highest mean suspended sediment concentration $\left(\sim 12 \mathrm{gl}^{-1}\right)$ followed by August $\left(8.9 \mathrm{gl}^{-1}\right)$.

Daily runoff and sediment discharges showed a good relationship for all rainy months with the coefficient of correlation $\left(R^{2}\right)$ ranging from 0.71 to 0.93 , with the overall coefficient of correlation at 0.70 (Figure 2.3). Base flow increases the daily runoff discharges towards the end of the rainy season as observed in the graph (Figure 2.4). 
Table 2.3 Mean (2013-2015) monthly rainfall, suspended sediment concentration, runoff and sediment discharges at Minizr catchment.

\begin{tabular}{cllll}
\hline Month & $\begin{array}{l}\text { Mean monthly } \\
\text { rainfall }(\mathrm{mm})\end{array}$ & $\begin{array}{l}\text { Mean monthly } \\
\text { runoff }\left(\mathrm{m}^{3}\right)\end{array}$ & $\begin{array}{l}\text { Mean monthly sediment } \\
\text { concentration }\left(\mathrm{g} \mathrm{l}^{-1}\right)\end{array}$ & $\begin{array}{l}\text { Mean monthly } \\
\text { sediment load }(\mathrm{t})\end{array}$ \\
\hline May & 82 & 251,000 & 6.2 & 1,890 \\
June & 191 & 568,000 & 7.6 & 5,400 \\
July & 383 & $1,078,000$ & 12.2 & 14,900 \\
Aug & 291 & $1,189,000$ & 8.9 & 12,300 \\
Sept & 240 & $1,306,000$ & 5.9 & 8,100 \\
Oct & 28 & $112,000(15$ days $)$ & 4.4 & 370 \\
STDEV & 131.8 & $509,628.7$ & 2.7 & 5730.3 \\
\hline
\end{tabular}
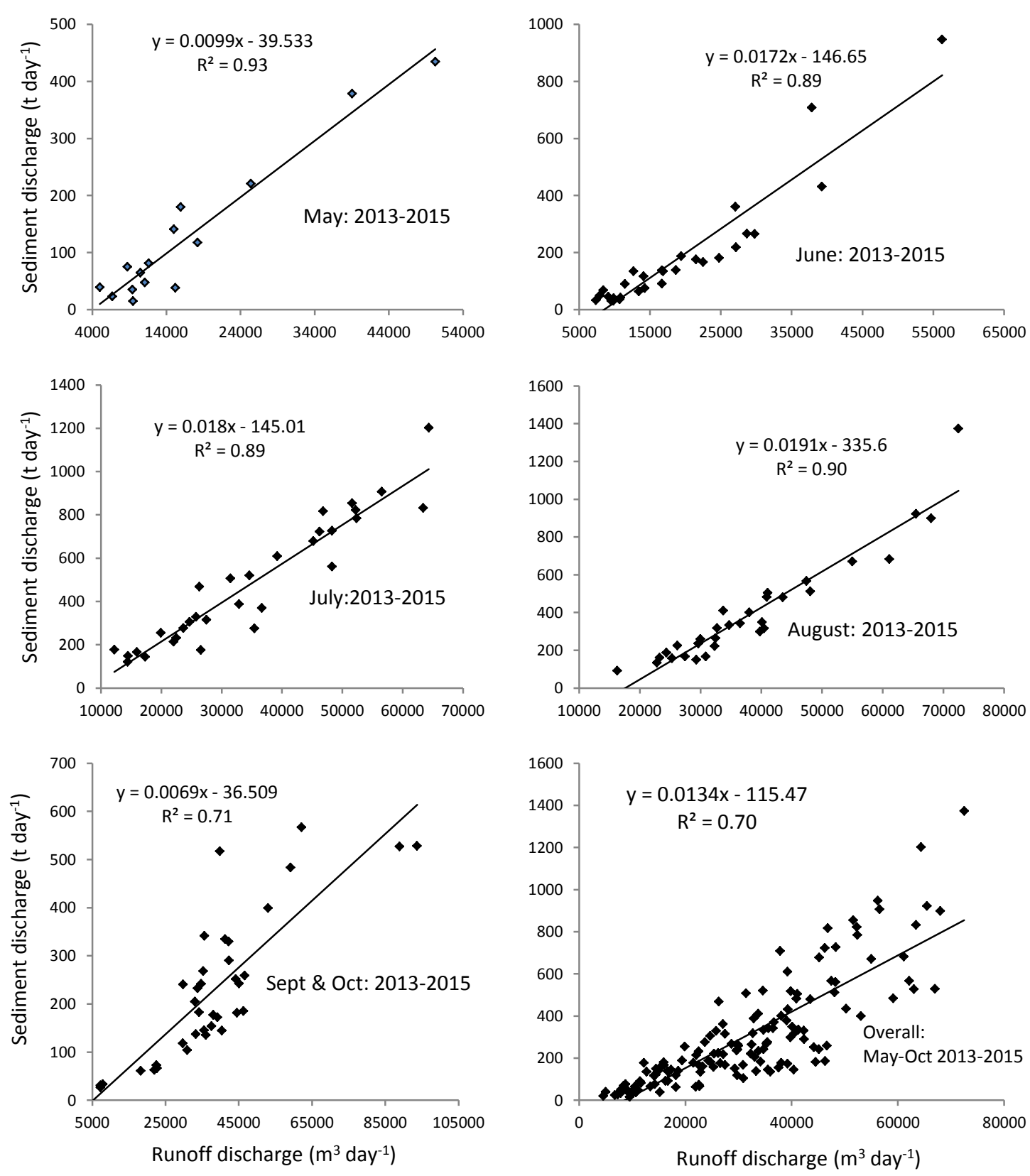

Figure 2.3 Relationship between daily runoff and sediment discharges from 2013-2015 at Minizr catchment 

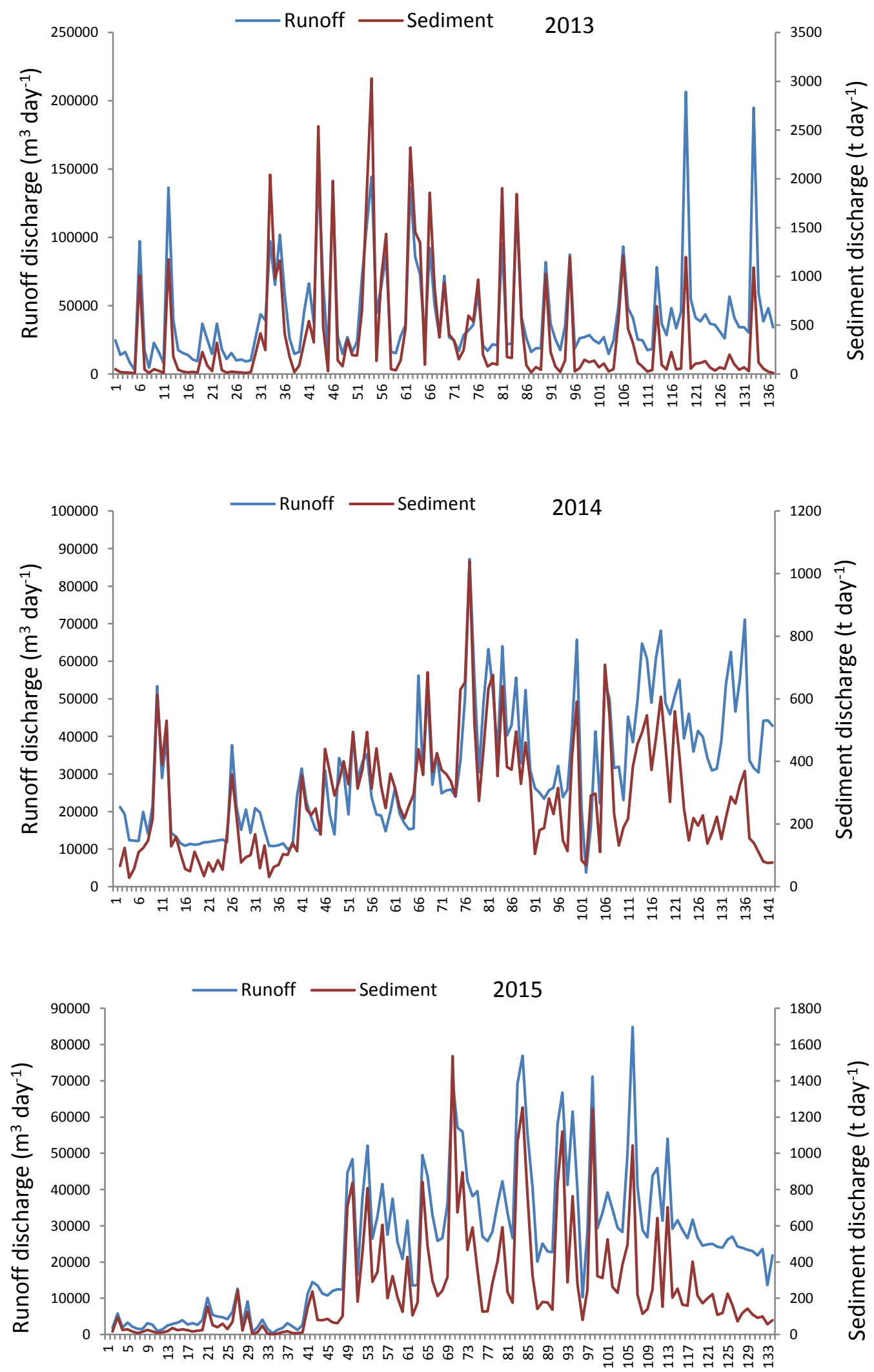

Sampling days from beginning to end of rainy season

Figure 2.4 daily runoff and sediment discharges at Minizr catchment from 2013-2015 


\section{Sediment source areas at sub-catchment scale}

The Midre-Genet sub-catchment produces approximately three times more sediment than TumeShafrie sub-catchment, indicating a large spatial variation for sediment production within the Minizr catchment. Mean annual sediment discharges from the three sub-catchments showed that MidreGenet (middle catchment) generated the most sediment ( 19,400 $t$ ) followed by Adibera (upper catchment; 13,100 t) and Tume-Shafrie (lowest catchment; 6,700 t). Area specific sediment yield (in $\mathrm{t} \mathrm{ha}^{-1} \mathrm{y}^{-1}$ ) was found to be 25.5, 16.8 and 13 at Midre-Genet, Adibera and Tume-Shafrie subcatchments, respectively.

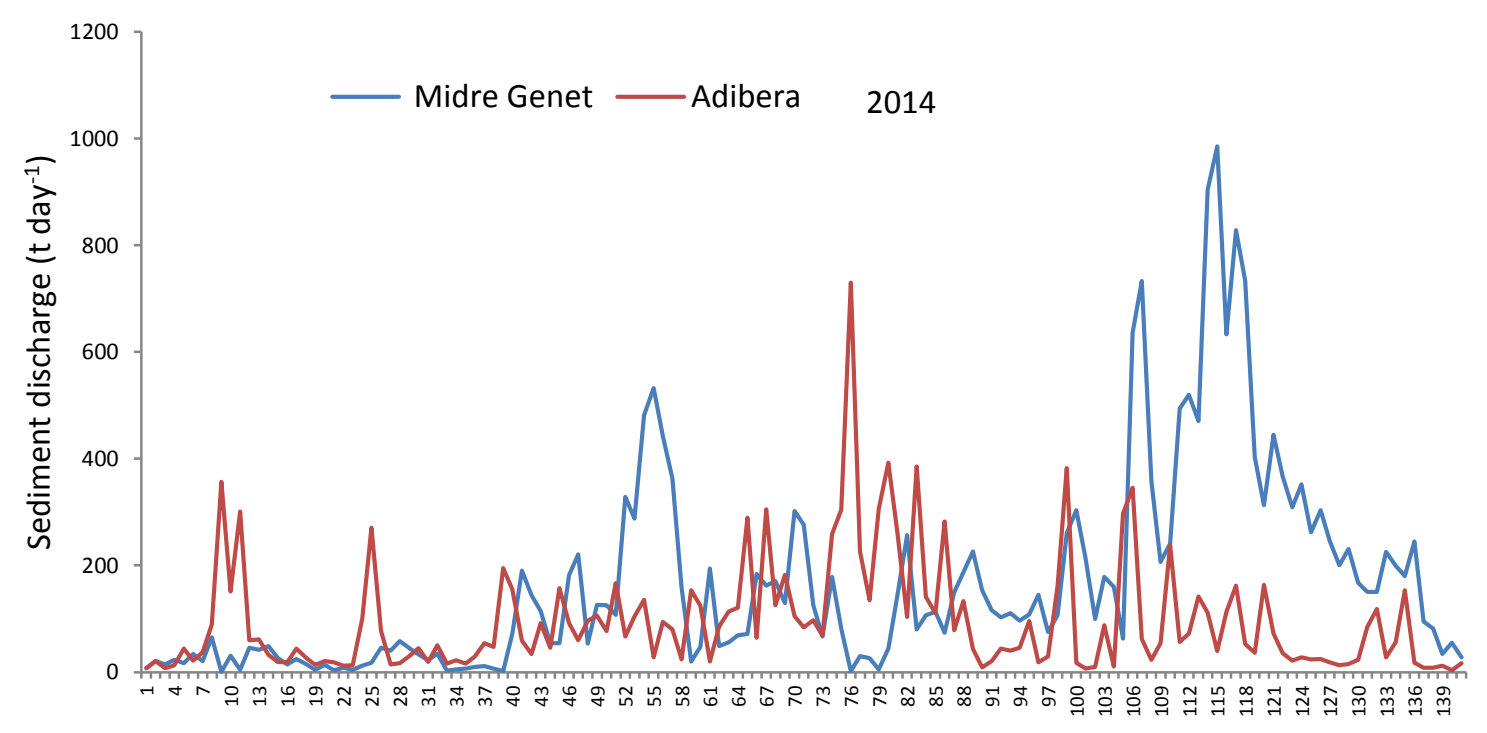

Figure 2.5 Daily sediment discharge from Midre Genet and Adibera sub-catchments

Sediment yields of the sub-catchments are not independent because the lower and middle subcatchments receive sediments from upstream, we deduct the sediment measured at the upper catchment from the lower one. Unlike the two sub-catchments (Adibera and Midre-Genet) sediment deposition occurs along Minizr river within Tume-Shafrie sub-catchment during rainfall events, which serves as sediment source for the next events. This increased the uncertainty for the daily sediment discharge for this catchment and hence we used the annual average data for sediment yield. Mean daily sediment discharge was higher from Midre-Genet sub-catchment than Adibera towards the end of the rainy season (Figure 2.5).

\section{Sediment transfer pathways}

Sediment is generated in different parts of the catchment, such as on agricultural fields, in gullies and from riverbanks, which is then transported to the catchment outlet through sediment transfer pathways (STPs). In Minizr catchment a total of $\sim 84 \mathrm{~km}$ of STPs were identified with an overall mean density of $4.0 \mathrm{~km} \mathrm{~km}^{-2}$, consisting of gullies $(\sim 6.6 \mathrm{~km})$, permanent rivers $(\sim 16.7 \mathrm{~km})$, intermittent rivers $(\sim 23 \mathrm{~km})$ and footpaths $(\sim 37.5 \mathrm{~km})$ (Table 2.4$)$. STP density was $\sim 4.7, \sim 3.8$ and $\sim 3.6 \mathrm{~km} \mathrm{~km}^{-2}$ for Midre-Genet, Adibera and Tume-Shafrie, respectively. Figure 2.6 shows a location map of existing STPs (rivers, footpaths and gullies), gullied areas and example pictures of STPs. The catchment 
comprises about 25 ha of gullied areas of which, about $60 \%$ was located in Midre-Genet and the remaining $40 \%$ in Adibera. There was no gullied area in Tume-Shafrie sub-catchment. The four measured gullies showed an annual development rate of $28 \mathrm{~m}$ long, $7 \mathrm{~m}$ wide and $2.5 \mathrm{~m}$ deep generating about $1950 \mathrm{~m}^{3}$ sediment to downstream rivers.

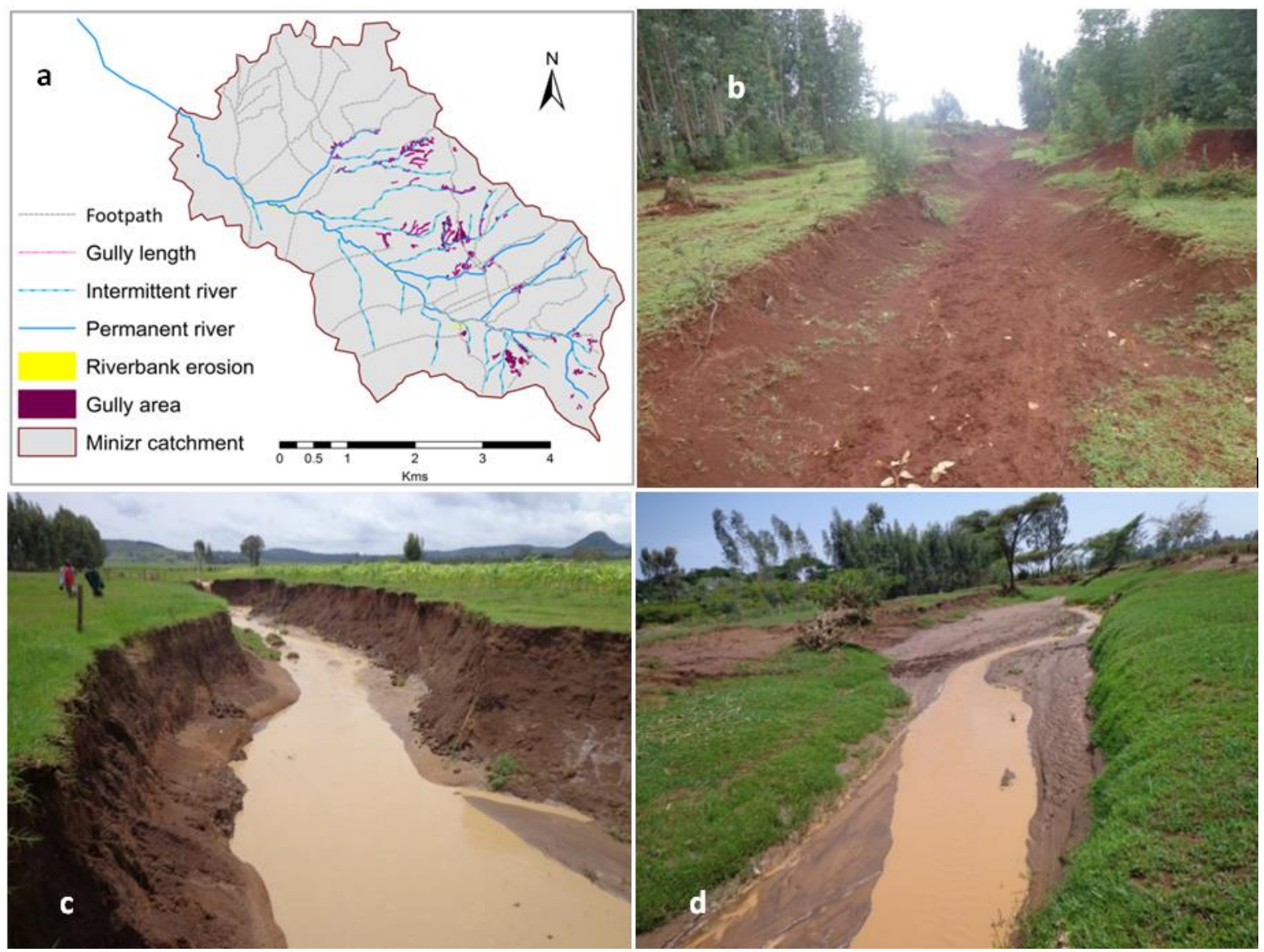

Figure 2.6 Location map of sediment transfer pathways (a), and example pictures of a footpath (b), a gully (c), and a river (d) in Minizr catchment.

Table 2.4 Lengths of sediment transfer pathways within the three sub-catchment

\begin{tabular}{|c|c|c|c|c|c|c|}
\hline \multirow{2}{*}{$\begin{array}{l}\text { Sub- } \\
\text { catchments }\end{array}$} & \multicolumn{5}{|c|}{ Sediment transport pathways } & \multirow[b]{2}{*}{$\begin{array}{l}\text { STPs density } \\
\left(\mathrm{km} \mathrm{km}^{-2}\right)\end{array}$} \\
\hline & $\begin{array}{l}\text { Intermittent } \\
\text { rivers }(\mathrm{km})\end{array}$ & $\begin{array}{l}\text { Permanent } \\
\text { rivers }(\mathrm{km})\end{array}$ & $\begin{array}{l}\text { Gullies } \\
(\mathrm{km})\end{array}$ & $\begin{array}{l}\text { Footpaths } \\
(\mathrm{km})\end{array}$ & Sum & \\
\hline Adibera & 7.2 & 5.5 & 2.7 & 14.5 & 29.9 & 3.8 \\
\hline Midre-genet & 12.8 & 3.2 & 3.9 & 16.0 & 35.9 & 4.7 \\
\hline Tume-Shafrie & 3.0 & 8.0 & 0 & 7.0 & 18.0 & 3.6 \\
\hline Sum & 23 & 16.7 & 6.6 & 37.5 & 83.8 & \\
\hline
\end{tabular}




\subsection{Discussion}

\section{Sediment load to Koga reservoir}

Daily, monthly and yearly suspended sediment discharges of Minizr catchment were calculated from the measured river discharge $\left(\mathrm{m}^{3} \mathrm{~s}^{-1}\right)$ and suspended sediment samples $\left(\mathrm{g} \mathrm{l}^{-1}\right)$. On average $\sim 43,000 \mathrm{t}$ of suspended sediment is entering Koga reservoir annually. Annual sediment yield ranged from $17 \mathrm{t}$ $\mathrm{ha}^{-1}$ in the year 2015 to $27 \mathrm{t} \mathrm{ha}^{-1}$ in the year 2013 with an average value of $21.5 \mathrm{t} \mathrm{ha}^{-1}$. This result agrees with the findings of previous studies in northwest Ethiopian highlands. For example, $\sim 25 \mathrm{t} \mathrm{ha}^{-1}$ $\mathrm{y}^{-1}$ (Setegn et al., 2010; Yeshaneh et al., 2014) and 8.6-55 $\mathrm{t} \mathrm{ha}^{-1} \mathrm{y}^{-1}$ (Mekonnen et al., 2015b). The result was also within the range of 3-49 $\mathrm{t} \mathrm{ha}^{-1} \mathrm{y}^{-1}$ found by Tamene et al. (2006a) in the northern part of Ethiopia.

Koga reservoir is receiving this amount of sediment from the $20 \mathrm{~km}^{2}$ Minizr catchment. Considering the entire runoff and sediment source area of the reservoir, Koga catchment $\left(163 \mathrm{~km}^{2}\right.$, excluding the reservoir), large amounts of sediment are expected to enter the reservoir. With a sediment yield of $21.5 \mathrm{t} \mathrm{ha}^{-1} \mathrm{y}^{-1}$ and average dry bulk density obtained from six reservoirs (1.26 $\mathrm{t} \mathrm{m}^{-3}$; Tamene et al. (2006a) in the northern part of Ethiopia, approximately $278,000 \mathrm{~m}^{3}$ of sediment is entering Koga reservoir from the whole Koga catchment annually, which agreed well with 269,000 $\mathrm{m}^{3}$ (Yeshaneh et al., 2014). Koga reservoir is losing $~ 0.33 \%$ of its storage volume annually and $0.04 \%(43,000 t ; 34,000$ $\mathrm{m}^{3}$ ) is the contribution of Minizr catchment. This will considerably compromise its water holding capacity and influence the $\sim 14,000$ subsistence farmers' households who are using the reservoir water for irrigated agriculture downstream of the reservoir. Therefore, immediate actions should be taken to trap the sediment and hence reduce its transport to the reservoir by implementing ST measures within the catchment disconnecting the sediment transfer pathways.

\section{Temporal variations of sediment discharge}

Sediment entering Koga reservoir showed inter-annual and intra-annual variations. Annual sediment discharge was higher in 2013 ( 54,000 t) than in 2014 ( 39,700 t) and 2015 ( 34,900 t). Two probable causes for these differences have been identified: a reduction in rainfall amount and construction of new ST measures. Rainfall in 2015 was 487 mm lower and in 2014 it was 325 mm lower than in 2013. In 2015, there was shortage of rainfall in the whole of Ethiopia, with droughts occurring in some parts of the country. New ST measures are constructed every year by the Bureau of Agriculture on untreated areas, which contributes to the reduction of sediment discharge.

Among the rainy months, most sediment was produced in July $(\sim 14,900 t)$, followed by August $(12,300 \mathrm{t})$. Out of the total sediment discharged from May to October, $63 \%$ was discharged in July and August. Daily sediment discharge was highest from the beginning of July to the end of August. This implies that Intra-annual (monthly and daily) sediment discharge and suspended sediment concentration were higher in the middle of the rainy season (July and August) than in the beginning and the end of the rainy season. This increase in sediment concentrations is most likely due to an increase in i) gully erosion because of increased sub-surface flow and ii) river bank erosion because of increased runoff flow inside river channels in July and August. Tebebu et al. (2010) found that subsurface flow played a bigger role in gully formation and development than surface runoff at Debre Mewi watershed. Rijkee et al. (2015) also found that sub-surface flow is an important cause of gully 
formation and development at Minizr catchment. In this study, during July and August extensive signs of subsurface flows were visible in and around gullies. With the implementation of SWC structures on all fields in the upland areas, infiltration increased substantially. The additional infiltration decreases overland runoff, and therefore, increases ground water flows toward the lowlands where gullies are located. This increase in ground water flows makes the area more susceptible to gully erosion through subsurface flow mechanisms in July and August. In addition to gully erosion, during our field surveys we observed river channel erosion and river bank slides in July and August due to high rainfall amounts and increased volume of runoff within the channels contributing sediment to the river system.

Once plant cover establishes towards the end of the rainy season, erosion from agricultural field is negligible (Easton et al., 2010; Mekonnen et al., 2015a). Results from this study showed, however, that although agricultural fields were covered with crops and there was an increased land cover in the catchment, sediment discharge amounts continued to be large up to the end of the rainy season, although with a decreasing rate. This is because part of the catchment underlain by Vertisols is ploughed by farmers during the high rainfall periods (from mid-August to mid-September) to plant legume crops like chick pea (Cicer arietinum) and grass pea (Lathyrus sativus). Another reason for maintained sediment discharge throughout the season is gully and river bank erosion, which showed active development in July and August as mentioned above.

\section{Spatial variation in sediment production}

From an applied (management) perspective, the small scale catchment is the scale at which catchment managers most often make decisions (Aksoy \& Kavvas, 2005; MOARD, 2005). Accordingly we classified our catchment into three sub-catchments Midre-Genet (760 ha), Adibera (780 ha) and Tume-Shafrie (500 ha) and quantified sediment production.

In the middle catchment, Midre-Genet, most sediment was produced ( $19,400 \mathrm{t})$, followed by the highest catchment, Adibera $(\sim 13,100 \mathrm{t})$ and the lowest catchment, Tume-Shafrie $(\sim 6,700 \mathrm{t})$. For this spatial variation in sediment production, three possible factors were identified. Firstly, sediment transfer pathways (STPs); the density of STPs was higher for the sub-catchment with high sediment discharge, Midre-Genet $\left(4.7 \mathrm{~km} \mathrm{~km}^{-2}\right)$, which implies an increase in landscape connectivity and sediment transport. STP density was lower in the sub-catchment with relatively low sediment discharge, Tume-Shafrie $\left(3.6 \mathrm{~km} \mathrm{~km}^{-2}\right)$, which implies lower sediment connectivity and less sediment transport. Catchment sediment production and STP density showed a direct relationship with $\mathrm{R}^{2}=$ 0.88 . Secondly, gully erosion is a contributing factor. After identifying that Midre-genet was the subcatchment contributing most sediment to the catchment outlet, we found that gullies develop fast and contribute large amounts of sediment in this sub-catchment. Annual average gully development rate was found to be $28 \mathrm{~m}$ long, $7 \mathrm{~m}$ wide and $2.5 \mathrm{~m}$ deep. The evaluated four gullies generated $1950 \mathrm{~m}^{3}$ of sediment to downstream rivers. Rijkee et al. (2015) investigated three gullies in the same catchment and found a soil losses of $74 \mathrm{t} \mathrm{ha}^{-1} \mathrm{y}^{-1}$. Sixty percent of the area affected by gully erosion was found in Midre-Genet, which is another reason for increased sediment production compared to the other sub-catchments. 
Adibera is the second sub-catchment in sediment production, in which $40 \%$ of the gully affected land was found. Tume-Shafrie sub-catchment did not experience any gully erosion and showed the least sediment production. Finally, availability of natural sediment sinks plays a role in spatial sediment variation. At the outlet of Tume-Shafrie sub-catchment a 24 ha wetland is found with a sediment trapping efficacy of $85 \%$ (Mekonnen et al., 2016c) in which a large part of the sediment could be deposited.

Differences in soil erosion triggering factors like land use/cover, slope, rainfall and soil type within a catchment will cause spatial variation in sediment production. In Minizr catchment, However, there was no large difference among the sub-catchments in land use/cover and rainfall. Land use/cover was dominated by agricultural fields followed by grazing lands in all sub-catchments. Rainfall ( $\mathrm{mm} \mathrm{y}^{-1}$ ) was almost similar, 1229 (Adibera), 1175 (Midre-Genet) and 1239 (Tume-Shafrie). Slope was different for the sub-catchments (Table 2.1).Concerning the soil type Adibera and Tume-Shafrie are dominated by Nitosols whereas Midre-Genet is dominated by Vertisols, which will create variation in soil erosion.

\section{Reducing sediment discharge}

To reduce the sediment entering Koga reservoir a holistic catchment scale treatment is preferred. Such an approach could for example consist of: (i) Implementing measures, which help to disconnect the sediment connectivity functions of STPS; (ii) Treating gully erosion using gully treatment measures (like check dams, sediment storage dams, plantations); (iii) Riverside plantations to treat riverbank erosion; (iv) Conserving natural sediment sinks like wetlands by designing management strategies because agricultural expansion has strongly affecting the existence of the wetland at Minizr catchment (Mekonnen et al., 2016c) and (v) Treating the most sediment source area first and moving to the least.

In this study, the amount of sediment entering Koga reservoir, spatial and temporal variation in sediment discharge and the role of STPs in connecting the landscape and enhancing sediment transport were assessed for the Minizr catchment. All of these will help to design and implement appropriate ST measures within the catchment. To develop complete information further studies are recommended, on sediment contributions from STPs like gullies, footpaths, river channels. Spatial variation in sediment production was assessed at sub-catchment scale but to know specific locations of sediment source areas cell-based studies are recommended at higher spatial resolution. Sediment load of the Koga reservoir from the total runoff contributing catchments was estimated based the measured data from Minizr catchment, which will serve as an awareness creation for decision makers and extension agents, however, further study for the total catchment or up-scaling studies from small catchments is recommended. 


\subsection{Conclusions}

Minizr catchment is an important source of runoff water for Koga reservoir and provides on average, $4,500,000 \mathrm{~m}^{3}$ runoff annually, mainly in the rainy season. With this runoff $43,000 \mathrm{t}$ of sediment is entering Koga reservoir annually $\left(21.5 \mathrm{t} \mathrm{ha}^{-1} \mathrm{y}^{-1}\right)$. Spatially, Midre-Genet sub-catchment is the main source of the sediment because of higher sediment transfer pathway (STP) density and a large area affected by gullies. Annual sediment discharge was higher in the year 2013 than in 2014 and 2015. Intra-annually sediment discharge was highest in July and August. Drainage channels, gullies and footpaths were found to be the main STPs enhancing sediment connectivity and transport. As a result large amount of sediment is entering Koga reservoir. Therefore, sediment trapping measures, which enhance sedimentation within the catchment and disconnecting the sediment connectivity functions of the STPs are needed. When implementing these measures priority areas should be addressed first. If sedimentation of the Koga reservoir continues its sustainable use will be in question and the large number of beneficiaries of the irrigation agriculture produces will be in problem. 


\section{Chapter 3}

\section{Soil conservation through sediment trapping: a review}

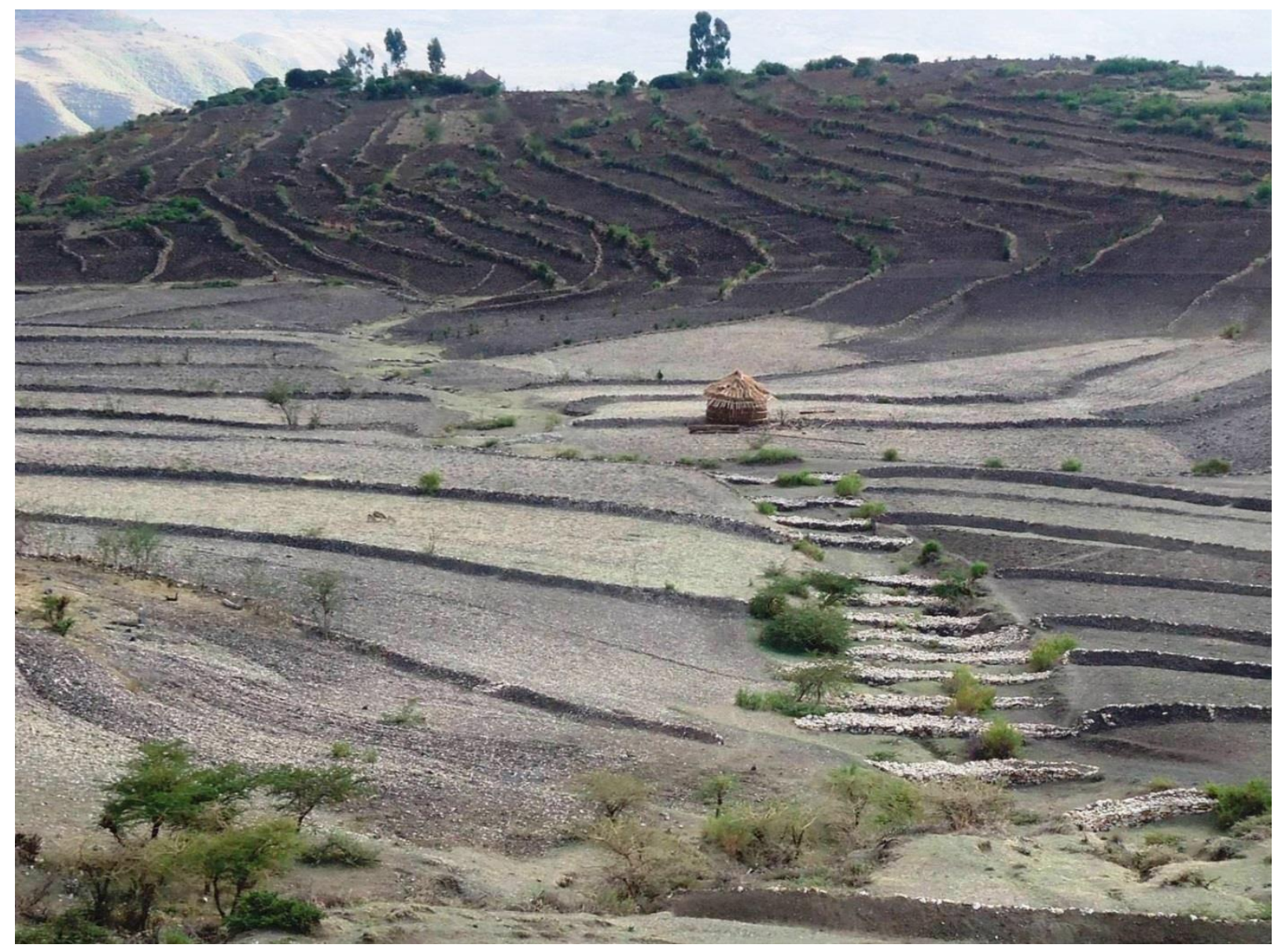

This chapter is published as:

M. Mekonnen, S.D. Keesstra, L. Stroosnijder, J.E.M. Baartman, J. Maroulis. 2015.

Soil conservation through sediment trapping: a review.

Land Degradation \& Development 26:544-556.

Published online in 2014 in Wiley Online Library (Wileyonlinelibrary.com) DOI:10.1002/Idr.2308 


\section{Soil conservation through sediment trapping: a review}

Abstract

Preventing the off-site effects of soil erosion is an essential part of good catchment management. Most efforts are in the form of on-site soil and water conservation measures. However, sediment trapping using off-site measures can be an alternative (additional) measure to prevent the negative off-site effects of soil erosion. Therefore, not all efforts should focus solely on on-site soil conservation, but also on the safe routing of sediment-laden flows and on creating sites and conditions where sediment can be trapped. Sediment trapping can be applied on-site and off-site and involves both vegetative and structural measures. This paper provides an extensive review of scientific journal articles, case studies, governmental reports, conference proceedings and book chapters that have assessed soil conservation efforts and the sediment trapping efficacy (STE) of vegetative and structural measures. The review is further illustrated through participatory field observation and stakeholders interview. Vegetation type and integration of two or more measures are important factors influencing STE. In this review, the STE of most measures was evaluated either individually or in such combinations. In real landscape situations, it is not only important to select the most efficient erosion control measures, but also to determine their optimum location in the catchment. Hence, there is a need for research that shows a more integrated determination of STE at catchment scale. If integrated measures are implemented at the most appropriate spatial locations within a catchment where they can disconnect landscape units from each other, they will decrease runoff velocity and sediment transport and, subsequently, reduce downstream flooding and sedimentation problems.

\subsection{Introduction}

Soil conservation will remain an important topic in the $21^{\text {st }}$ century. As increasing pressure mounts on agricultural lands to feed an ever growing global population, land exploitation and unabated soil erosion will occur, especially in developing parts of the world (Lal, 2001), and in other regions were the intensification of agriculture is taking place (Cerda et al., 2009; Zema et al., 2012) or where natural or human-driven disturbances take place: forest fires (Lasanta \& Cerdà, 2005), landslides (Douglas et al., 2013), heavy rainfall events (Ziadat \& Taimeh, 2013), land abandonment (Cerdà, 1997b). The exploitation of land resources results from a number of factors including extensive deforestation for fuel wood, expansion of cultivation into steep erosion-prone areas and over grazing pressures (Zeleke, 2000; Bewket, 2002; Ritsema, 2003; Amsalu \& de Graaff, 2007). The impacts of uncontrolled on-site (or in-field) soil erosion can result in sedimentation off-site causing a reduction in water storage capacity of reservoirs downstream, in addition to reduced water quality from increasing water turbidity and pesticide runoff that is introduced into lakes and rivers through agricultural runoff, thereby affecting riverine habitats and sensitive ecological processes (Morgan, 2005; Chiu et al., 2007; Hrissanthou et al., 2010; Rodrigues \& Silva, 2012).

Soil research and extension has mainly focused on measures that reduce or prevent on-site erosion. Although successes have been reported (Schwilch et al., 2013), overall adoption and up-scaling of these measures by farmers is disappointing (Stroosnijder, 2012). Therefore, alternative approaches 
are needed to decrease soil erosion and thus help to ensure the longevity and viability of agricultural practices (Leh et al., 2013).

This paper explores one such alternative for soil conservation, known as sediment trapping (ST). The rationale for ST is that in many practical situations, especially in developing nations, soil erosion is often too difficult to control. Thus, one premise is that it is better to no longer put all our collective efforts into on-site soil conservation but rather to focus on understanding the sediment and flow dynamics of the whole catchment and try to retard it along its sediment transfer pathways (Keesstra, 2007; Keesstra et al., 2009b; Abedini et al., 2012; Baartman et al., 2012). The challenge is to create more sinks in the catchment where sediment can be trapped, preferably in a cost effective or even profitable way. Many semiarid slopes have patchy vegetation distribution that acts as sinks for sediment coming from the bare (source) areas (Cerdà, 1997a). This strategy helps to reduce the flow connectivity, which can reduce the soil and water losses.

Although many studies have assessed the effects of ST on an experimental basis, this information has not previously been applied holistically at a catchment scale. In this study, we split the ST measures into two categories: (i) those that promote sedimentation within farmers' fields 'on-site' measures and (ii) those outside the sphere of influence of individual farmers' fields 'off-site' measures. On-site ST measures reduce overland flow velocity and thereby retard sediment transport, resulting in sediment deposition within fields before sediment can be discharged into streams (Fiener \& Auerswald, 2003; Lee et al., 2003; McKergow et al., 2004; Edem et al., 2012; Wanyama et al., 2012). Off-site ST measures reduce concentrated runoff velocity within the (ephemeral) gully and river channel system thereby enhancing infiltration of water and deposition of sediment into ponds and behind check dams (Fiener et al., 2005; Abedini et al., 2012) and into the riparian zone (Newson \& Large, 2006; Keesstra et al., 2012).

Besides distinguishing between on-and off-site, the ST measures are also grouped according to the methodology of sediment retardation: (i) vegetative, (ii) structural and (iii) combined vegetative and structural measures. Examples of on-site vegetative measures include grass strips, tree or shrub buffers, riparian vegetation and grassed waterways; terraces are on-site structural measures constructed on farmlands whereas sediment basins or ponds and check dams are off-site structural measures mostly located in (ephemeral) gullies and rivers.

The sediment trapping efficacy (STE) of various on- and off-site ST measures, defined as the percentage of sediment trapped compared to the amount of sediment that passed a control location, without the trapping measures, is explored for each type of ST measure used. STE is site and vegetation specific and can be affected by the combination of two or more ST measures (Fiener et al., 2005; Nyssen et al., 2009a; Zhang et al., 2010b).

\subsection{Materials and methods}

A critical review was carried out of 91 scientific journal articles, 6 case studies and 9 other publications (governmental reports, conference proceedings and book chapters). This review is 
further illustrated through participatory field observation (Figures 3.1-3.7) in the upper part of Blue Nile basin, Ethiopia, which included field work in 2013, consisting of interviewing stakeholders (government officials at Bureau of Agriculture), farmers, agricultural development agents and scientists (at Bahir Dar University), and measuring waterway, grass strip, terrace, check dam and pond characteristics including explanatory factors such as soil depth, land use/cover and average slope gradient.

\section{3 vegetative sediment trapping measures}

Vegetative ST measures can be grouped into grass strips, shrub and tree buffers, riparian vegetation and grassed waterways which can be established along contours, at the edge of fields or along streams or other water bodies to reduce runoff velocity and sediment transport and enhance sediment deposition (Dillaha et al., 1989; Lee et al., 2003; Yuan et al., 2009). Table 3.1 provides a summary of previous studies displaying the vegetative ST measures used, their location, STE and scale.

Table 3.1 Studies of vegetative sediment trapping (ST) measures

\begin{tabular}{|c|c|c|c|c|c|c|c|}
\hline Types & Scale & $\begin{array}{l}\text { Duration } \\
\text { (years) }\end{array}$ & $\begin{array}{l}\text { Rainfall } \\
(\mathrm{mm})\end{array}$ & $\begin{array}{l}\text { Soil } \\
\text { (texture) }\end{array}$ & Location & $\begin{array}{l}\text { Sediment Trapping } \\
\text { Efficacy (STE) \% }\end{array}$ & References \\
\hline \multicolumn{8}{|l|}{ Grass strips } \\
\hline Lemon grass & Plot & 2 & 1050 & clay loam & Uganda & $\begin{array}{l}72-92 \% \text { (natural), } \\
54-78 \% \text { (simulated) }\end{array}$ & Wanyama et al., 2012 \\
\hline Paspalum & Plot & 2 & 1050 & clay loam & Uganda & $\begin{array}{l}65-88 \% \text { (natural), } \\
60-80 \% \text { (simulated) }\end{array}$ & Wanyama et al., 2012 \\
\hline Elephant grass & Plot & 2 & 1050 & clay loam & Uganda & $\begin{array}{l}62-84 \% \text { (natural), } \\
48-70 \% \text { (simulated) }\end{array}$ & Wanyama et al., 2012 \\
\hline Sugarcane & Plot & 2 & 1050 & clay loam & Uganda & $\begin{array}{l}56-82 \% \text { (natural), } \\
34-67 \% \text { (simulated) }\end{array}$ & Wanyama et al., 2012 \\
\hline Vetiver grass & - & 4 & 3585 & clay & Australia & $65 \%$ & McKergow et al., 2004 \\
\hline Brome grass & Plot & 1 & - & silt loam & USA & $70-85 \%$ & Robinson et al., 1996 \\
\hline Centipede grass & Plot & 3 & 1753 & - & Japan & $24-73 \%$ & Shiono et al., 2007 \\
\hline $\begin{array}{l}\text { Switchgrass + woody } \\
\text { vegetation }\end{array}$ & Plot & - & - & loamy & USA & $\begin{array}{l}92 \% \text { and } 97 \% \\
\text { (simulated) }\end{array}$ & Lee et al., 2003; 2000 \\
\hline Switchgrass & plot & 2 & 805 & - & USA & $\begin{array}{l}70 \% \text { and } 95 \% \\
\text { (natural) }\end{array}$ & Lee et al., 2003; 2000 \\
\hline Switchgrass + vetiver & Plot & - & - & - & - & $90 \%$ & Meyer et al., 1995 \\
\hline \multicolumn{8}{|l|}{ Shrub \& tree buffers } \\
\hline Shrub & Plot & 1 & 530 & loess & China & $45-61 \%$ & Zhang et al., 2010a \\
\hline $\begin{array}{l}\text { Streamside } \\
\text { management zones }\end{array}$ & Watershed & - & 203 & sandy loams & $\begin{array}{l}\text { Georgia, } \\
\text { USA }\end{array}$ & $71-99 \%$ & $\begin{array}{l}\text { Ward \& Jackson, } \\
2004\end{array}$ \\
\hline $\begin{array}{l}\text { Streamside } \\
\text { management zones }\end{array}$ & Watershed & 3 & 1020 & $\begin{array}{l}\text { Loams, silt } \\
\text { loam }\end{array}$ & $\begin{array}{l}\text { Virginia, } \\
\text { USA }\end{array}$ & $97 \%$ & Lakel et al. 2010 \\
\hline $\begin{array}{l}\text { Mixed deciduous } \\
\text { forest buffer }\end{array}$ & Plot & 1 & - & Silt loam & USA & $76-86 \%$ & $\begin{array}{l}\text { Schoonover et al., } \\
2006\end{array}$ \\
\hline Giant cane & Plot & 1 & 35 & Silt loam & USA & $94-100 \%$ & Schoonover et al., 2006 \\
\hline Acacia tree belt & Plot & - & 35 & $\begin{array}{l}\text { Chromic } \\
\text { luvisol }\end{array}$ & Australia & $91-100 \%$ & Leguedois et al., 2008 \\
\hline $\begin{array}{l}\text { Remnant forests + } \\
\text { grass }\end{array}$ & Watershed & 3 & 1020 & - & USA & $100 \%$ & Knight et al., 2010 \\
\hline Remnant forests alone & Watershed & 3 & 1020 & - & USA & $80 \%$ & Knight et al., 2010 \\
\hline Tree + grass & $\begin{array}{l}\text { Cultivated } \\
\text { field }\end{array}$ & 4 & 716 & - & Italy & $92 \%$ & Borin et al., 2005 \\
\hline \multicolumn{8}{|l|}{ Grassed waterway } \\
\hline Grassed waterways & Watershed & 8.5 & 804 & $\begin{array}{l}\text { Loamy } \\
\text { Inceptisol }\end{array}$ & Germany & $\begin{array}{l}97 \% \text { (with), } 77 \% \\
\text { (without) waterway }\end{array}$ & $\begin{array}{l}\text { Fiener \& Auerswald, } \\
2003\end{array}$ \\
\hline Grassed waterways & Watershed & 2 & 890 & $\begin{array}{l}\text { Silty clay } \\
\text { loam }\end{array}$ & USA & $\begin{array}{l}18 \% \text { runoff, } \\
65 \% \text { sediment }\end{array}$ & Dermisis et al., 2010 \\
\hline Grassed waterways & Watershed & 9 & 834 & $\begin{array}{l}\text { Loamy } \\
\text { Inceptisol }\end{array}$ & Germany & $\begin{array}{l}87 \% \text { runoff, } \\
93 \% \text { sediment }\end{array}$ & $\begin{array}{l}\text { Fiener \& Auerswald, } \\
2006\end{array}$ \\
\hline
\end{tabular}




\section{Grass Strips}

Grass strips are bands of grass mostly planted in agricultural fields along contours at specified vertical intervals (Figure 3.1). Grass strips reduce the velocity and sediment transport capacity of flowing water by retarding and spreading the concentrated surface runoff, which enhances sediment deposition within and upslope of the grass strip (Hurni, 1986). Through time, grass strips may develop into terraces and reduce the gradient of the field. This process is known as slow forming or progressive terracing (Kagabo et al., 2013).

The STE of a grass strip depends on the grass species. Wanyama et al. (2012) evaluated the STE of four tropical grass species, lemon grass (Cymbopogon citratus), elephant grass (Pennisetum purpureum), paspalum (Paspalum notatum) and sugarcane (Saccharum officinarum L.) in croplands in Uganda, under natural and simulated rainfall conditions. Due to their spreading growth pattern and dense network of fine roots, lemon and paspalum grass showed significantly greater STE than elephant grass and sugarcane. The authors concluded that tropical grass strips provide a practical means for reducing sediment transport from croplands.

In the Johnstone River catchment in north Queensland, Australia, Vetiver grass strips planted on a steep and intensively cropped field under high annual natural rainfall condition (3585 mm), trapped $>85 \%$ of the bedload and $25-65 \%$ of the suspended sediment (McKergow et al., 2004). In Nigeria, such grass strips trapped $\sim 5$ times more sediment than the control (Edem et al., 2012) on a runoff plot experiment. The mean total sediment yield was $29 \mathrm{~kg} \mathrm{ha}^{-1}$ from the control plot versus $6 \mathrm{~kg} \mathrm{ha}^{-1}$ from the Vetiver plots. Brome grass trapped $70-85 \%$ of the sediment at different buffer widths from cropland runoff on silty loam soil in lowa, USA (Robinson et al., 1996). Centipede grass (Eremochloa ophiuroides (Munro) Hack) trapped $24-73 \%$ of sediment in field plots under natural rainfall conditions in Japan (Shiono et al., 2007).

In lowa, USA the STE of switch grass (Panicum virgatum L.) alone and switch grass-woody vegetation buffers were studied (Lee et al., 2000; Lee et al., 2003) under simulated and natural rainfall conditions on a $4.1 \mathrm{~m}$ by $22.1 \mathrm{~m}$ bare field with (a) no buffer, (b) a $7.1 \mathrm{~m}$ wide switch grass buffer and (c) a $16.3 \mathrm{~m}$ wide switch grass-woody vegetation buffer. The switch grass alone and switch grasswoody vegetation combination trapped $70 \%$ and $92 \%$ of the incoming sediment under natural rainfall, and $95 \%$ and $97 \%$ under simulated rainfall, respectively.

The physical characteristics of the different grass species are important in retarding runoff through upslope ponding. For example, hedges of switch grass and Vetiver (Vetiveria zizanioides (L.) Nash) caused backwater depths of up to $40 \mathrm{~cm}$ and trapped $>90 \%$ of sediment coarser than $125 \mu \mathrm{m}$ in areas of concentrated overland flow (Meyer et al., 1995). The effect of grass litter and leaves on ST was also studied on the Loess Plateau, China (Pan et al., 2010) where perennial local grazing grass, black rye (Loliumperenne L.) were tested on slopes of $3-15^{\circ}$ applying three treatments: C- control with intact grass, NL- no litter i.e. without grass covering the soil surface and NLL - no litter or leaves i.e. only grass stems and roots. STE ranged from $42-69 \% ; 41-72 \%$ and $37-59 \%$ for the C, NL and NLL treatments, respectively, and thus Pan et al. (2010) concluded that grass litter and leaves had no significant influence on STE of the local grass. 


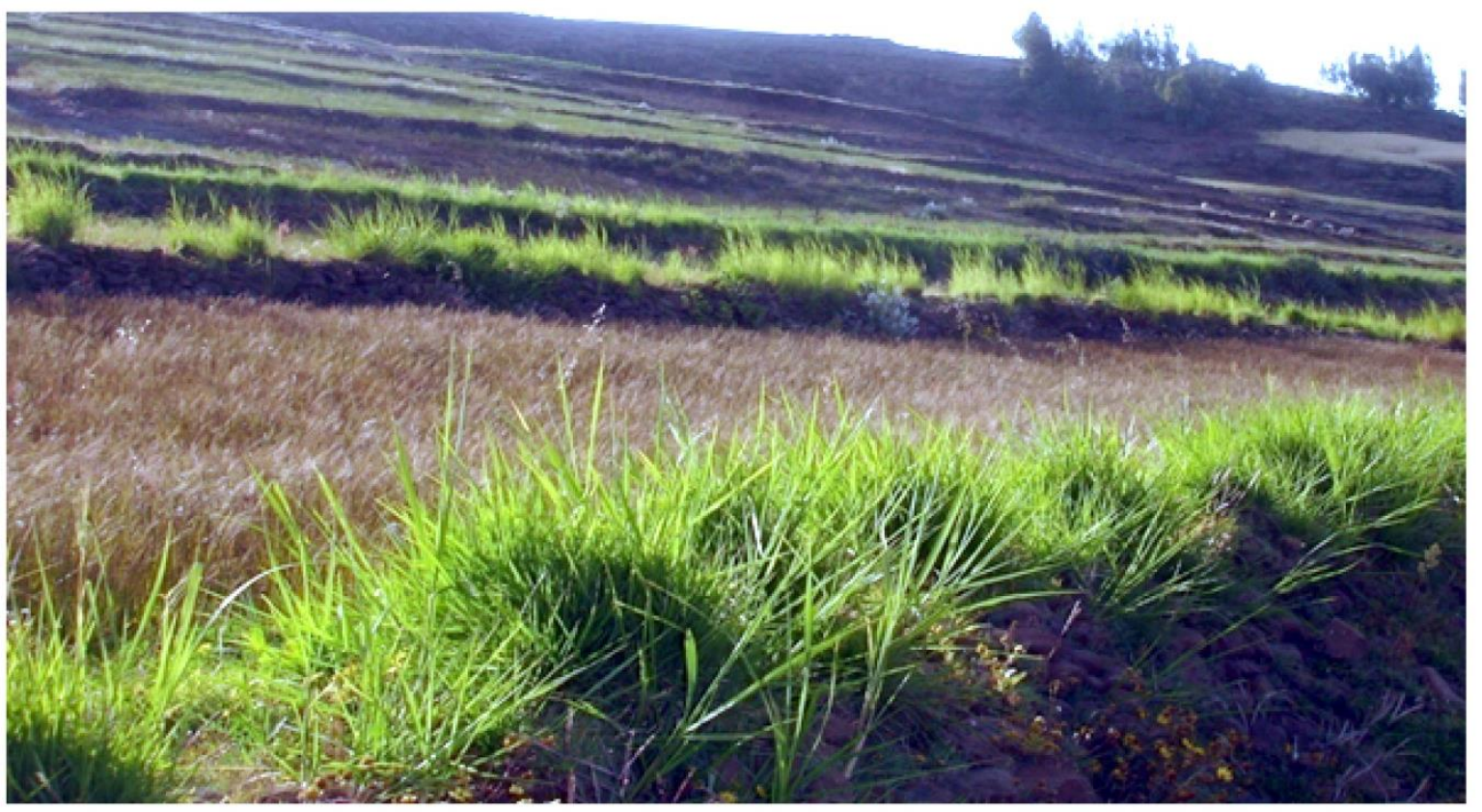

Figure 3.1 Example of a vegetative sediment trapping measure: grass strip upper Blue Nile Basin, northwest Ethiopia (Photo by Mulatie Mekonnen)

\section{Shrub and Tree Buffers}

Tree or shrub buffers are vegetative barriers established between farmlands and rivers, to trap transported sediment before reaching nearby streams and waterways (Figure 3.2). In Northern Shaanxi Province, China, on a $15^{\circ}$ slope and loess soil, native shrub species (Caragana Korshinskii Kom) reduced runoff rates by $22-32 \%$, sediment concentration by $45-61 \%$ and sediment yield rates by $64-79 \%$ compared to the control plot (Zhang et al., 2010a). Treatments were (i) bare soil as a control plot, without shrub cover, (ii) low shrub cover (30\%) and (iii) high shrub cover (80\%). Average sediment concentrations were $12.4 \mathrm{~g} \mathrm{l}^{-1}, 6.8 \mathrm{~g} \mathrm{l}^{-1}$ and $4.8 \mathrm{gl}^{-1}$, for the control, low shrub and high shrub covers respectively. Near Booreowa, New South Wales, Australia on a $6^{0}$ slope and chromic luvisol soil a tree belt of Acacia was able to trap $94 \%$ of eroded sediment, with STE ranging from 91100\% (Leguedois et al., 2008).

Ward and Jackson (2004) investigated the benefits of streamside management zones for two Georgia Piedmont clear cuts in the USA, in reducing sediment transport from concentrated overland flow, and recorded 15-49 $\mathrm{t} \mathrm{ha}^{-1}$ of accumulated sediment, with STE ranging between 71-99\%. In Virginia, Upper James River basin, streamside management zones trapped an average of $24.8 \mathrm{t} \mathrm{ha}^{-1} \mathrm{y}^{-1}$ of sediment (Lakel et al., 2010), which is 38 times higher than the control treatment $\left(0.65 \mathrm{t} \mathrm{ha}^{-1} \mathrm{y}^{-1}\right)$. With $97 \%$ of the sediment trapped, a streamside management zone represents an effective best management practice that should be included in most sediment harvest planning.

A buffer of giant cane (Arundinaria gigantea (Walt.) Muhl.) on a $1 \%$ slope with a silty loam soil, in southern Illinois, USA reduced incoming sediment by $94-100 \%$ while a mixed deciduous forest buffer reduced sediment by $76-86 \%$ (Schoonover et al., 2006). On an annual and seasonal basis, the giant cane buffer consistently outperformed the forest buffer in significantly reducing sediment loads. 
In the French Southern Alps, Burylo et al. (2012), investigated the buffering effects of morphologically contrasting woody species, i.e. (i) broadleaf species (Buxus sempervirens and Lavandula angustifolia) and (ii) coniferous species (Juniperus communis and Pinus nigra). They found that the broadleaf species Lavandula and Buxus trapped the highest amount of sediment per unit volume: 3.7 and 2.8 times more than Juniperus; and 1.9 and 1.5 times more than Pinus. Remnant forests with grass filters buffered $100 \%$ of the concentrated surface runoff, whereas remnant forests without adjacent grass filters buffered $80 \%$ of concentrated flow (Knight et al., 2010). This suggests that even though natural remnant forests provide substantial buffering capacity, the addition of an adjacent grass filter further reduces sediment loads entering streams. In northeast Italy, on a $1.8 \%$ slope with Cambisol soil, a $6 \mathrm{~m}$ buffer strip, rows of trees with grass planted in the middle reduced runoff over a three year period by $78 \%$ and sediment by $92 \%$ compared to the control (Borin et al., 2005).

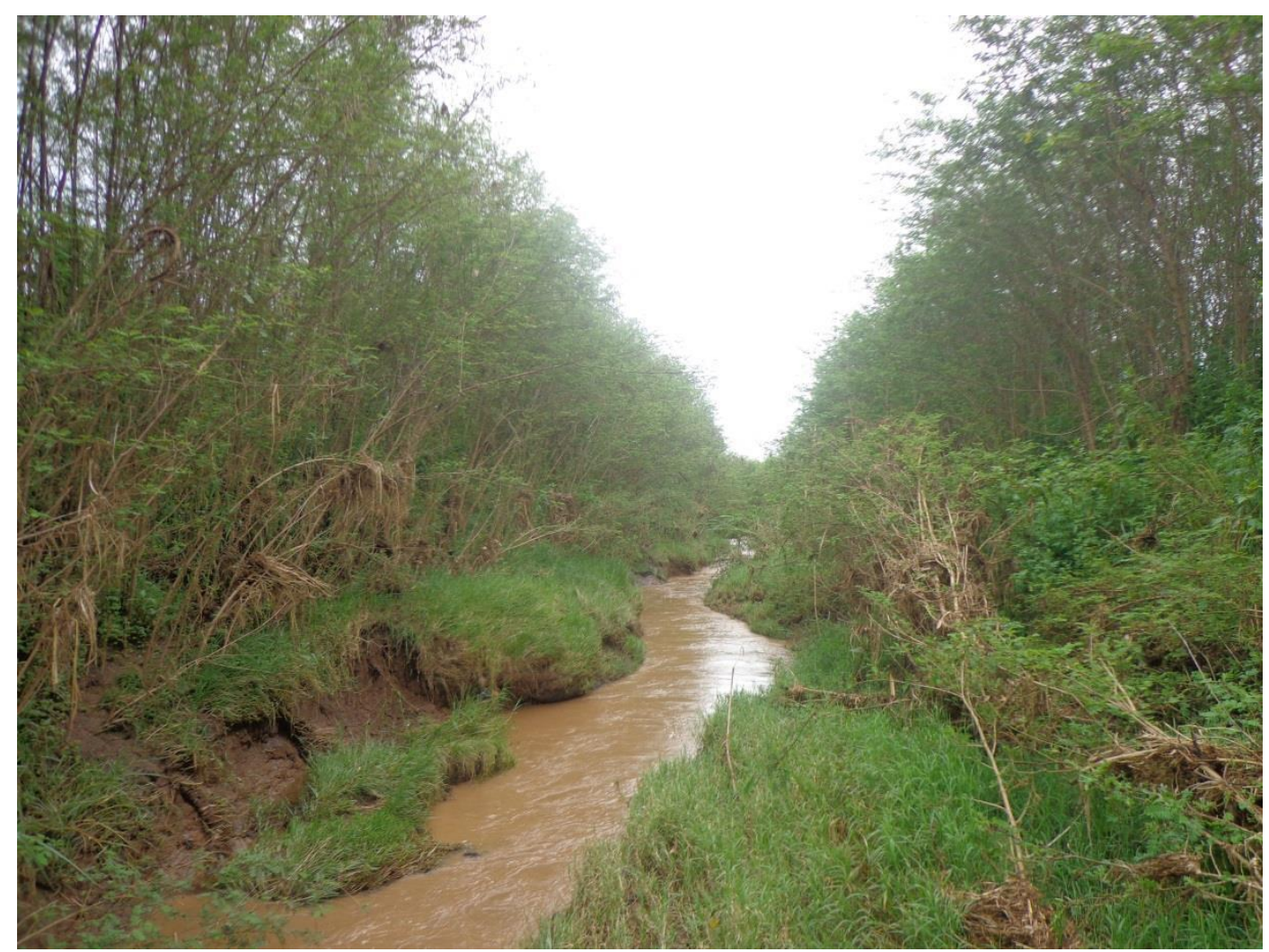

Figure 3.2 Example of a vegetative sediment trapping measure: riverside tree buffer upper Blue Nile Basin, Minizr catchment, northwest Ethiopia (Photo by Mulatie Mekonnen)

\section{Grassed Waterways}

Waterways are either man-made or natural drainage lines channelling runoff from adjacent agricultural fields to local streams. Waterways can be either lined with stone or covered with grass (Figure 3.3) to help prevent soil erosion and gully formation. Grassed waterways are areas where runoff concentrates and are often planted with grasses to reduce runoff, enhance infiltration and reduce sediment transport and gully formation by decreasing flow velocity (Bracmort et al., 2004; Fiener \& Auerswald, 2006; Dermisis et al., 2010). 


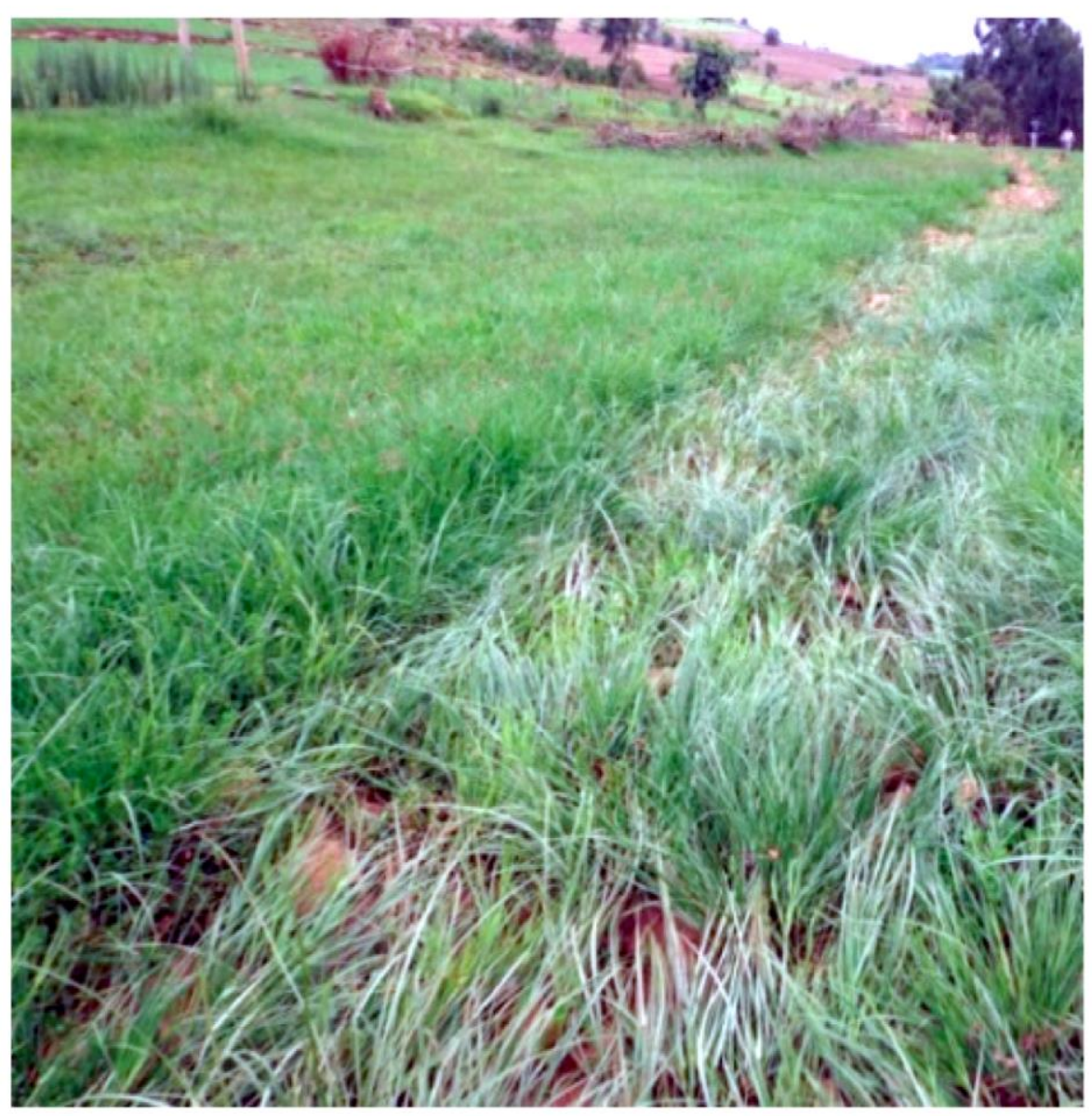

Figure 3.3 Example of a vegetative sediment trapping measure: grassed waterway upper Blue Nile Basin, northwest Ethiopia (Photo by Mulatie Mekonnen)

Fiener and Auerswald (2003) studied the STE of grassed waterways and concluded that they exhibited great potential in reducing runoff and sediment from agricultural areas within a catchment. This is based on a 9 year experiment in two adjacent watersheds in southern Germany of 13.7 and 9.4 ha, respectively, with loamy inceptisols and slopes ranging from 3.6 to $5.3 \%$. For the two watersheds with and without grassed waterways, runoff was reduced by $90 \%$ and $10 \%$, and sediment load was reduced by $97 \%$ and $77 \%$, respectively, due to reductions in runoff velocity, higher infiltration rates and increased surface storage capacity. Dermisis et al. (2010) obtained similar results for a watershed in Clear Creek (4\% average slope), USA, where a $600 \mathrm{~m}$ long and $11.5 \mathrm{~m}$ wide grassed waterway reduced runoff volume by $18 \%$ and sediment yield by $65 \%$.

(Fiener \& Auerswald, 2006) evaluated the STE of grassed waterways at the watershed scale in Germany. In one of the sub-watersheds, in addition to other soil and water conservation (SWC) measures already in place, a 22-48 m wide and $290 \mathrm{~m}$ long grassed waterway was established. Runoff and sediment loads were reduced by $87 \%$ and $93 \%$ for the without and with grassed waterway treatments, respectively. Thus the potential of grassed waterways for reducing sediment transport from agricultural watersheds is more effective, if combined with other ST measures. 


\section{Riparian Vegetation}

Riparian vegetation and channel form in headwater catchments play an important role in the resulting water and sediment dynamics of rivers further downstream (McKergow et al., 2003; Wainwright et al., 2003; Gao, 2008). Vegetation causes flow retardation within the channel and on the riverbanks due to increased roughness and flow obstruction.

Modelling results by Keesstra et al. (2012) in a Polish catchment showed an increase in the effect of riparian vegetation on catchment flow dynamics, with an increase in return period of the modelled peak discharge. On a $6 \mathrm{~km}^{2}$ agricultural catchment in Western Australia with gentle slope, sandy soils and $799 \mathrm{~mm}$ average annual rainfall, suspended sediment concentration and loads were $90 \%$ lower after the riparian buffer was created due to reduced bank erosion and increased channel stability (McKergow et al., 2003). At lowa's Loess Hills, riparian buffers trapped $4.8 \mathrm{t} \mathrm{ha}^{-1} \mathrm{y}^{-1}$ of sediment from a 27.6 ha runoff contributing area on a loess soil at 5-20\% slope (Tomer et al., 2007). In a 77 ha watershed in southeast Brazil, with mean slopes of $10 \%$, the riparian buffers were found to trap $54 \%$ of total sediment yield (12 $\mathrm{t} \mathrm{ha}^{-1} \mathrm{y}^{-1}$ ) (Sparovek et al., 2002). At the catchment scale, integrating riparian buffers with other conservation measures that are more appropriate for reducing on-site soil erosion can help to reduce river sediment loads (Verstraeten et al., 2006).

\subsection{Structural sediment trapping measures}

Structural ST measures are designed to intercept runoff, reduce sediment transport and trap sediments either from surface runoff or river flow. Examples of such measures include terraces, check dams, dams, basins and ponds. Structural ST measures can be grouped according to their location either as on-site or off-site. On-site measures mainly consist of terraces, which can be constructed from soil, stone or a combination. Off-site measures, such as check dams, are built from stone, sandbags, wood or gabions in the drainage channel, whereas ponds or basins are constructed using dikes or stone barriers. Dams can have a very dramatic effect on water and sediment transfer on the scale of a catchment. When runoff enters into the storage areas, its velocity reduces providing time for the suspended sediment and bed load to settle. Table 3.2 summarizes the studies that were used in this review of structural ST measures.

\section{Terraces}

Terraces are graded or level barriers built on sloping land along contours at specified vertical intervals either from soil, stone or other materials (Figure 3.4). They are structural measures designed to reduce runoff velocity, increase infiltration and to retard erosion and sediment transport. In the long term, terraces reduce slope gradient forming bench terraces due to the accumulated sediment (Bosshart, 1997; Gebremichael et al., 2005).

Garbrecht and Starks (2009) assessed sediment yield reduction due to terraces, conservation tillage and gully reshaping at Fort Cobb, in West-Central Oklahoma. Based on suspended-sediment and discharge measurements on major tributaries within the watershed, the average annual suspendedsediment yield reduced from $760 \mathrm{t} \mathrm{y}^{-1} \mathrm{~km}^{-2}$ (pre-conservation) to $108 \mathrm{t} \mathrm{y}^{-1} \mathrm{~km}^{-2}$ (post-conservation), with targeted conservation efforts leading to a measurable reduction in watershed sediment yield. 
Mekonen and Tesfahunegn (2011) investigated the STE of stone bunds in the Medego watershed, Ethiopia and found that sediment accumulated at a rate of $65.3 \mathrm{t} \mathrm{ha}^{-1} \mathrm{y}^{-1}$. Also in Ethiopia, Gebremichael et al. (2005) determined that the annual rate of sediment accumulated behind stone bunds was $59 \mathrm{t} \mathrm{ha}^{-1}$, while total soil loss was $77 \mathrm{t} \mathrm{ha}^{-1}$. In central Java, Sukristiyonubowo et al. (2010) estimated that annually during wet and dry seasons, incoming sediment into paddy fields was 6.44 and $1.19 \mathrm{t} \mathrm{ha}^{-1}$, while outgoing sediment was 1.89 and $0.14 \mathrm{t} \mathrm{ha}^{-1}$, respectively.

Where agricultural land abandonment does occur and the abandoned terrace is rapidly re-vegetated, soil erosion diminishes whilst commensurately, STE increases (Grove \& Rackham, 2001). Furthermore, soil properties such as organic matter content, soil structure and rate of infiltration all improve (Kosmas et al., 2000). However if vegetation regeneration is slow or absent, abandoned terraced fields are vulnerable to erosion and gully formation due to terrace failure and crust formation, which increases runoff and reduces infiltration (Lesschen et al., 2008). Possible mitigation measures include: (i) maintenance of terrace walls in combination with increasing vegetation cover on the terrace, and (ii) re-vegetation of runoff concentration areas with grass.

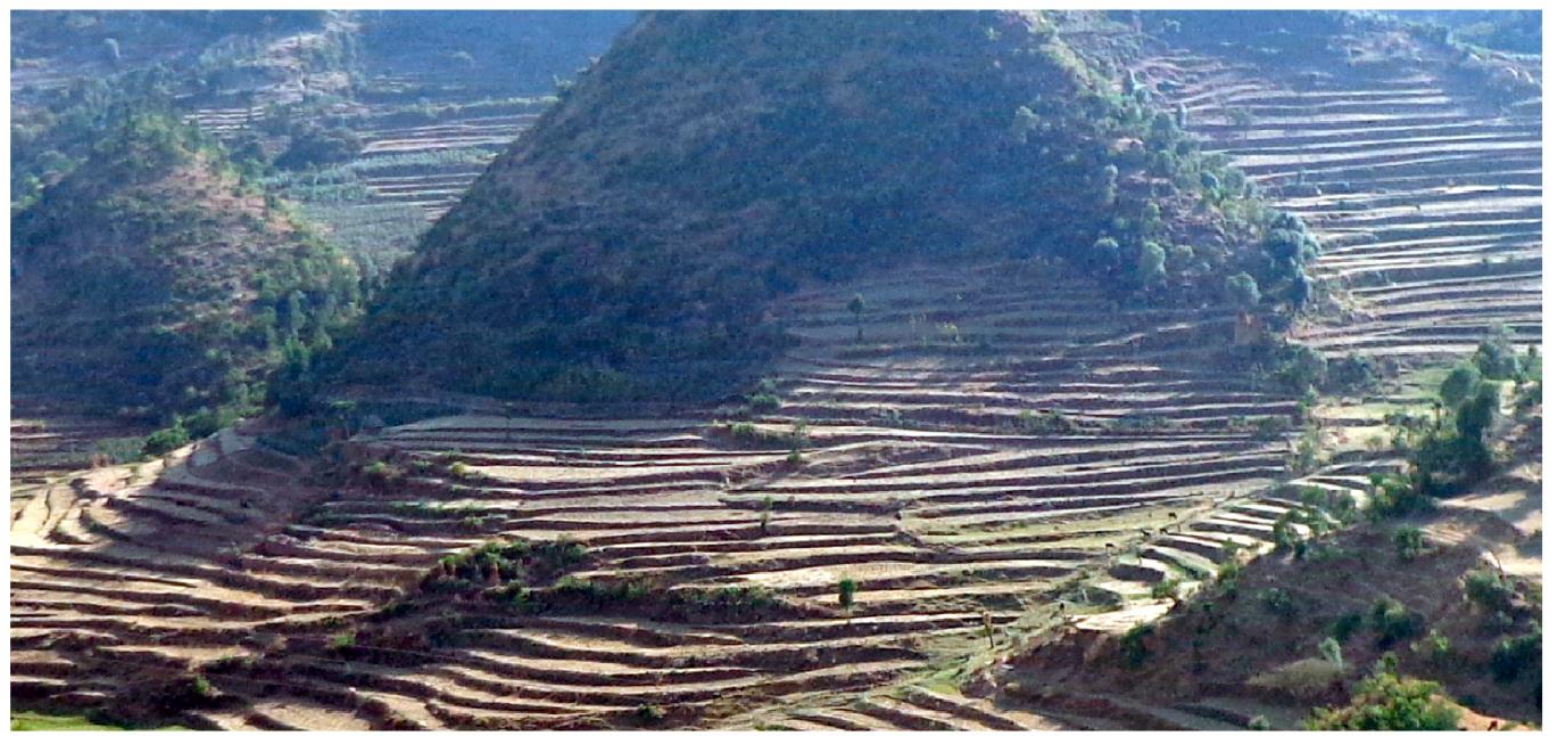

Figure 3.4 Examples of structural sediment trapping measures: terraces northeast Ethiopia (Photo by Mulatie Mekonnen)

\section{Basins and Ponds}

Sediment basins or ponds are defined as off-site surface water management structures, which capture runoff and sediment in an artificial impoundment and prevent sediment discharge into downstream lakes and reservoirs (Iqbal et al., 2003; Fiener et al., 2005). Sediment ponds are built within channels or at the edge of fields to trap sediment from concentrated runoff and thus prevent off-site sedimentation (Figure 3.5). Sediment ponds constructed within channels can also trap sediment resulting in stream bank erosion, which is a major source of sediment to downstream rivers and dams (Ramos-Scharrón \& MacDonald, 2007). 
Fiener et al. (2005) monitored four ponds with a volume of $30-260 \mathrm{~m}^{3}$ on a 22 ha field of arable land over 8 years in southern Germany, and found that the ponds trapped 54-85\% (1.0-15.3 t ha $\left.{ }^{-1} \mathrm{y}^{-1}\right)$ of incoming sediment and temporarily stored $200-500 \mathrm{~m}^{3}$ of runoff. These ponds efficiently reduced offsite sedimentation and their efficacy was further improved when combined with on-site erosion control measures, which further reduced sediment and runoff. During the first year all ponds were silted (up to $0.5 \mathrm{~m}$ ) but the sediment input into the detention ponds decreased to less than $1.0 \mathrm{t} \mathrm{ha}^{-1}$ $\mathrm{y}^{-1}$ due to soil conservation measures and the storage volume of the ponds was not highly influenced by siltation after the first year. Markle (2009) demonstrated the efficacy of a sediment pond in a Californian almond orchard, which trapped $80-84 \%$ of the sediment. According to Verstraeten and Poesen (2001b), a typical pond of $1000 \mathrm{~m}^{3}$ with a catchment area of 25 ha in Belgium, showed a short term STE of $58-100 \%$ and a long term (33 yrs.) STE of $68 \%$. In Belgium, Verstraeten and Poesen (2002) tested the STE of 13 different sized ponds $\left(50 \mathrm{~m}^{3}-5 \mathrm{mill}^{3} \mathrm{~m}^{3}\right)$ with a catchment area of 25-50 000 ha with alfisol soils, revealing a STE of $10-72 \%$.

Halide et al. (2003) evaluated the STE of constructed vegetated and non-vegetated ponds in Indonesia and Australia. The average deposition rate in the vegetated pond $\left(63 \mathrm{~g} \mathrm{~m}^{-2} \mathrm{~h}^{-1}\right)$ was higher than in the non-vegetated pond $\left(14 \mathrm{~g} \mathrm{~m}^{-2} \mathrm{~h}^{-1}\right)$. While Hupp et al. (2008) assessed sediment deposition over a three year period from 20 transects in the Atchafalaya Basin, Louisiana, USA. Transect mean sedimentation rates ranged from $2-42 \mathrm{~mm} \mathrm{y}^{-1}$ while the basin trapped $6.72 \times 10^{6} \mathrm{t}$ of sediment annually.

Construction sites (especially road construction) are areas where soil readily becomes unstable due to physical disturbance and thus are important sources of sediment (Anderson \& Macdonald, 1998; Ramos Scharrón, 2010). Graded unpaved roads produce 5.7-580 t ha ${ }^{-1} \mathrm{y}^{-1}$ of sediment, which was $40 \%$ higher than ungraded roads in St. John, U.S. Virgin Islands (Ramos-Scharrón \& MacDonald, 2007). Hence, construction sites required ST measures to intercept runoff and trap sediment before discharging runoff into downstream water bodies. In North Carolina, two sediment basins of different designs were evaluated within active construction sites (Markusic \& McLaughlin, 2008). The trap (sized for a 10-year storm event) with a rock outlet, was found to have $35 \%$ STE while the basin (designed for a 25-year storm event with established vegetation), had an overall efficacy of $99 \%$. McCaleb and McLaughlin (2008) monitored five ST basins on construction sites in North Carolina; STE at the three rock outlet basins was $40-73 \%$, while a basin with surface outlets trapped $>99 \%$ of the sediment.

\section{Check Dams}

Gully and river bank erosion has been observed to contribute significantly to overall catchment scale sedimentation (Poesen et al., 2003; Ramos-Scharrón \& MacDonald, 2007; Keesstra et al., 2009a). To counter this issue, check dams are mostly constructed within gullies and channels to help prevent gully erosion and trap sediment (Figure 3.6). A check dam can be classified as a structural measure established within ephemeral rivers and gullies. It is a fixed structure, constructed either from timber, sandbags, gabion, loose rock, masonry or concrete, to control concentrated water flow and 
trap sediment in an erodible channel (McGraw-Hill, 2003) and is an effective strategy for reducing sediment loss (Ran et al., 2008; Sougnez et al., 2011; Wang et al., 2011).

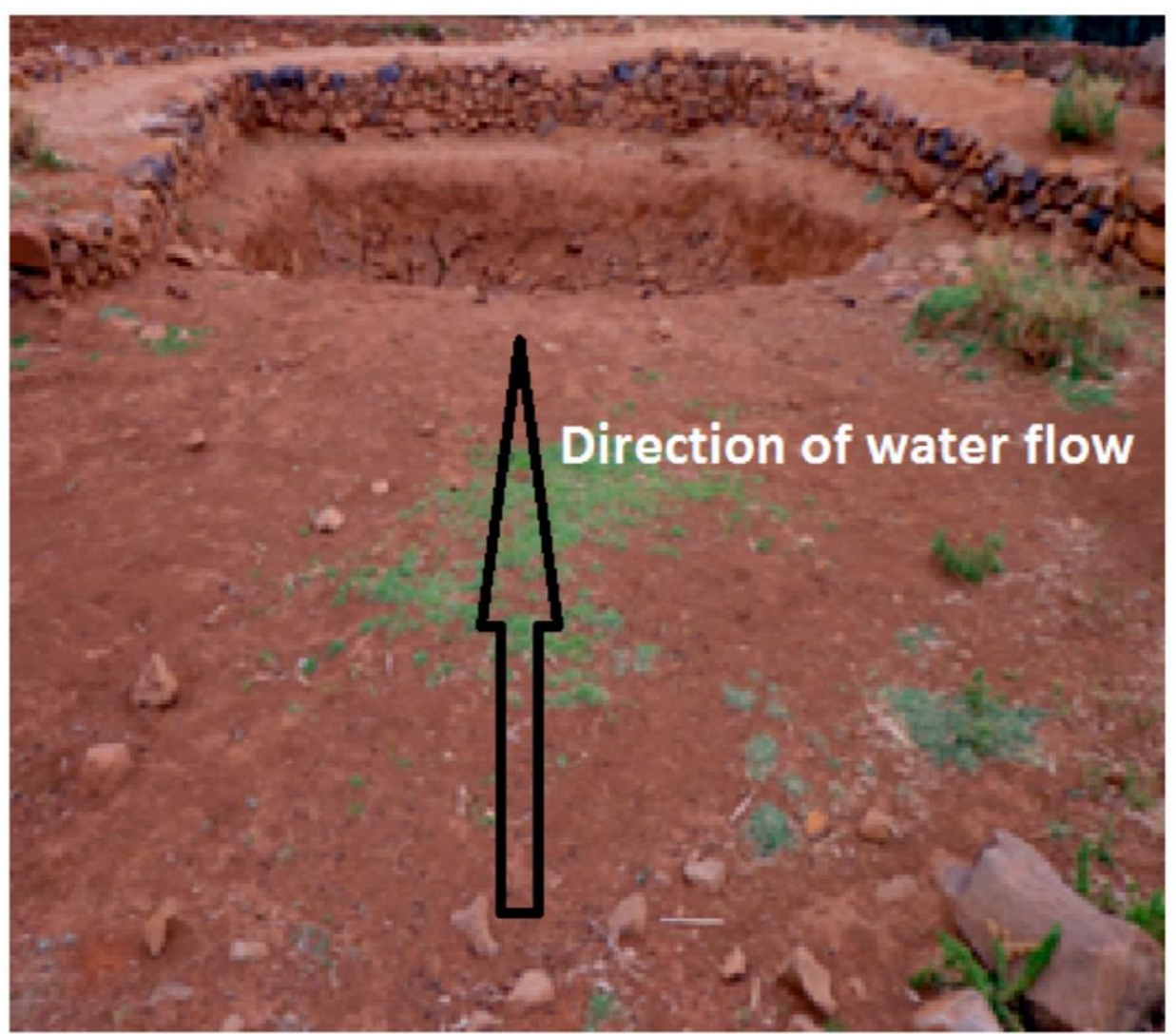

Figure 3.5 Examples of structural sediment trapping measures: a sediment pond northwest Ethiopia (Photo by Mulatie Mekonnen)

Wang et al. (2011) found that $>100000$ check dams store 21 billion $\mathrm{m}^{3}$ of sediment in the Loess Plateau of China in 50 years after construction. In Malaysia, Abedini et al. (2012) evaluated the STE of 3 check dams and their effectiveness in maintaining downstream reservoir storage capacity, which collectively trapped $6162 \mathrm{~m}^{3}$ of sediment. Ran et al. (2008) found that the amount of sediment retained by check dams at the outlets of five catchments in China, was 4205, 2640, 15000, 1590 and $1360\left(10^{3} \mathrm{t}\right)$ over 26 years, with reductions in sediment by check dams being $57.8 \%, 37.2 \%, 62.1 \%$, $72.2 \%$, and $64.7 \%$, respectively, compared with other SWC measures. Sougnez et al. (2011) estimated the sediment volume trapped by 20 check dams in southern Spain as ranging from $4-920 \mathrm{~m}^{3}$ for catchments with a drainage area varying from 1.5-317 ha. 


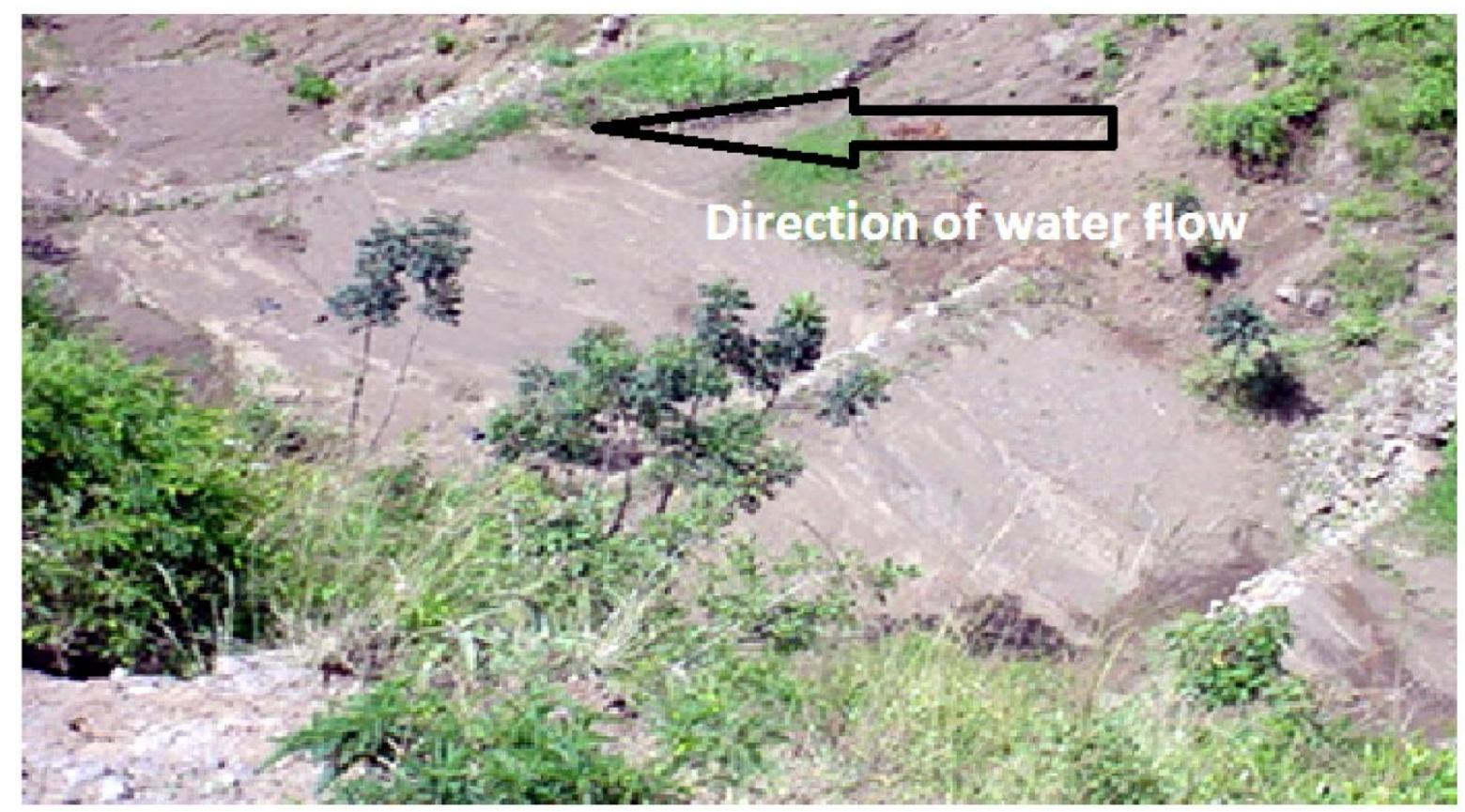

Figure 3.6 Examples of structural sediment trapping measures: check dams northeast Ethiopia (Photo by Mulatie Mekonnen)

Table 3.2 Studies on structural sediment trapping measures (terrace, basins or ponds and check dam)

\begin{tabular}{|c|c|c|c|c|c|c|}
\hline Types & Scale & Location & $\begin{array}{l}\begin{array}{l}\text { Duration } \\
\text { (years) }\end{array} \\
\end{array}$ & $\begin{array}{l}\text { Rainfall } \\
(\mathrm{mm})\end{array}$ & $\begin{array}{l}\text { STE (\%) or trapped } \\
\text { sediment }\left(m^{3}, t, M g\right)\end{array}$ & References \\
\hline \multicolumn{7}{|l|}{ Terraces } \\
\hline Terraces & Watershed & Oklahoma & 3 & - & $\begin{array}{l}760 \& 108 \mathrm{Mg} \mathrm{v}^{-1} \mathrm{~km}^{-2} \text { (pre \& } \\
\text { post conservation) }\end{array}$ & $\begin{array}{l}\text { Garbrecht \& Starks, } \\
2009\end{array}$ \\
\hline Stone bunds & Watershed & Ethiopia & 1 & 700 & $65.3 \mathrm{tha}^{-1} \mathrm{y}^{-1}$ & $\begin{array}{l}\text { Mekonen \& } \\
\text { Tesfahunegn, } 2011\end{array}$ \\
\hline Stone bunds & Plots & Ethiopia & - & 700 & 59 t ha $^{-1} y^{-1}$ & $\begin{array}{l}\text { Gebremichael et al., } \\
2005\end{array}$ \\
\hline Terraces & - & Java & 2 & - & $4.55 \& 1.05 \mathrm{t} \mathrm{ha}^{-1}$ & $\begin{array}{l}\text { Sukristiyonubowo et } \\
\text { al., } 2010\end{array}$ \\
\hline \multicolumn{7}{|c|}{ Basins \& ponds } \\
\hline Ponds & Watershed & Munich & 8 & 834 & $54-85 \%$ & Fiener et al., 2005 \\
\hline Pond & Watershed & California & - & - & $80-84 \%$ & Markle , 2009 \\
\hline Pond & Watershed & Belgium & - & - & $58-100 \%$ & $\begin{array}{l}\text { Verstraeten \& } \\
\text { Poesen, 2001b }\end{array}$ \\
\hline Pond & Watershed & Belgium & - & 750 & $10-72 \%$ & $\begin{array}{l}\text { Verstraeten \& } \\
\text { Poesen, } 2002\end{array}$ \\
\hline Basins & - & N. America & 3 & - & $6.72 \times 10^{\circ} \mathrm{Mg} \mathrm{y}^{-1}$ & Hupp et al., 2008 \\
\hline Basins & - & USA & - & - & $35-99 \%$ & $\begin{array}{l}\text { Markusic \& } \\
\text { McLaughlin, } 2008\end{array}$ \\
\hline \multicolumn{7}{|l|}{ Check dams } \\
\hline Check dams & Watershed & China & - & - & 21 billion $\mathrm{m}^{3}$ & Wang et al., 2011 \\
\hline Check dams & Watershed & Malaysia & - & 2500 & $6,162 \mathrm{~m}^{3}$ & Abedini et al., 2012 \\
\hline Check dams & Watershed & China & - & - & $10465 \mathrm{t} \mathrm{km}^{-2} \mathrm{y}^{-1}$ & Ran et al., 2008 \\
\hline Check dams & Watershed & Spain & - & 300 & $4-920 \mathrm{~m}^{5}$ & Sougnez et al., 2011 \\
\hline
\end{tabular}

$* \mathrm{~m}^{3}$-cubic meter, t-Metric tonnes, Mg-megagram 


\subsection{Combined measures}

Vegetative measures can be used to stabilize structural measures and improve their STE. Several researchers argue that to effectively trap sediment and ensure the sustainability of ST measures, it is important to combine both vegetative and structural measures (Nyssen et al., 2009b; Zhang et al., 2010b). In general, more sediment can be trapped using a combination rather than with single measures (Fiener et al., 2005; Zhang et al., 2010b). Figure 3.7 illustrates the combination of vegetative and structural measure; after the construction of terraces, grasses are planted on the bunds and on sandbag check dams.

In a 6.6 ha watershed in southwest lowa, on a 2-16\% slope with silt loam soils, the STE of switch grass (Panicum Virgatum L.) and bench terracing were evaluated (Rachman et al., 2008). Bench terracing reduced runoff and sediment yield by $9 \%$ and $58 \%$, respectively, but their combined effects gave the highest reduction in runoff (22\%) and sediment yield (79\%) compared to individual effects. According to Fisseha et al. (2011), a structural measure, fanya juu, trapped $64 \%$ of the sediment and its STE increased to $75 \%$ and $80 \%$ when combined with elephant grass and Vetiver grass, respectively, on a Eutric Cambisol soil, with $1167 \mathrm{~mm}$ average annual rainfall and 20-22\% catchment slope in northwest Ethiopia.
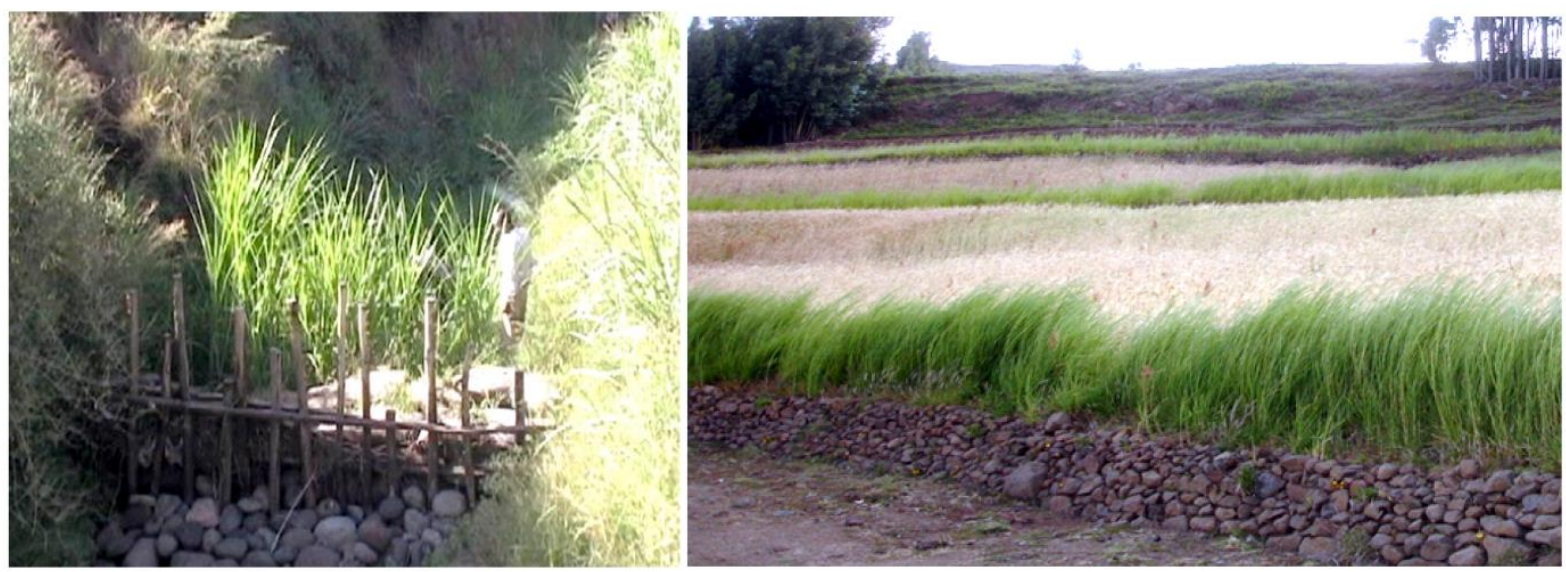

Figure 3.7 Examples of the combined application of vegetative and structural measures for sediment trapping northwest Ethiopia (photo by Mulatie Mekonnen): check dams combined with grass (left) and terrace combined with grass strip on top (right)

\subsection{Integrated measures}

Integrated ST representing the application of all required ST measures on their specific location within the catchment is the most effective approach to manage and control sediment movement compared to individual and combined measures (Nyssen et al., 2009a; Nyssen et al., 2009b; Zhang et al., 2010b). For example, grasses can be planted in waterways and on terraces, tree or shrub buffers can be established along streams or rivers, infiltration trenches, terraces or grass strips can be raised in fields, controlled grazing can be used on grazing lands while area closure can be practiced on degraded lands. Check dams and sediment ponds can also be implemented within gullies or drainage channels. According to Zhang et al. (2010b), the integrated application of trees, grass, terrace and 
sediment dams reduced mean annual runoff by $3.16-3.42 \times 10^{8} \mathrm{~m}^{3} \mathrm{y}^{-1}$ and mean annual sediment yield by $0.71-1.07 \times 10^{8} \mathrm{t}^{-1}$ in the Wuding River basin, China. In Germany, SWC measures without grassed waterways reduced sediment by $87 \%$ but their efficacy increased to $93 \%$ when integrated with grassed waterways (Fiener \& Auerswald, 2006).

The integrated impact of stone bunds, vegetation re-generation, controlled grazing and check dams was studied at a catchment scale in Ethiopia (Nyssen et al., 2009a). Results show that sediment yield decreased from 8.5 to $1.9 \mathrm{t} \mathrm{ha}^{-1} \mathrm{y}^{-1}$ and sediment delivery ratio decreased from 0.6 to 0.21 . The STE of SWC measures and reservoirs were evaluated by Peng et al. (2010) in the Yellow River Basin, China over 58 years and found that there was a $40 \%$ reduction in total sediment by SWC measures, $30 \%$ by reservoirs, $20 \%$ by precipitation reduction and $10 \%$ by other human activities.

Evrard et al. (2008) studied the effectiveness of a grassed waterway and three earthen dams in a 300 ha cultivated watershed in the Belgian loess belt. Runoff and sediment discharge was reduced by $69 \%$ and $93 \%$ between the grassed waterways inflow and outflow. Before the installation of the control measures, specific sediment yield of the catchment was $3.5 \mathrm{t} \mathrm{ha}^{-1} \mathrm{y}^{-1}$ with ephemeral gullies observed each year. Since control measures have been installed, no (ephemeral) gullies have developed and the specific sediment yield of the watershed dropped to a mean of $0.5 \mathrm{t} \mathrm{ha}^{-1} \mathrm{y}^{-1}$. Sediment budgets before and after the implementation of integrated sediment trapping measures were compared in a 187 ha catchment in Ethiopia (Nyssen et al., 2009b). The measures applied include the building of stone bunds, regrowth of vegetation on steep slopes and other marginal land, stubble grazing abandoned, and check dams built in gullies. Within six years, annual soil loss decreased from 14.3 to $9.0 \mathrm{t} \mathrm{ha}^{-1}$ and sediment deposition increased from 5.8 to $7.1 \mathrm{t} \mathrm{ha}{ }^{-1}$. Thus implementing ST measures in an integrated way is an effective strategy to curtail and manage soil loss and represents an important way to combat land degradation in tropical mountainous areas.

\subsection{Final considerations and future research agenda}

From upstream to the outlet of a catchment, runoff and sediment passes numerous landscape sections that may be more or less connected to each other. Sedimentological connectivity, which refers to the physical transfer of sediment from its source to its sinks through the drainage basin (Bracken \& Croke, 2007) or the transfer of sediment from one location to another (Hooke, 2003) is an important concept in understanding sediment dynamics. Moreover, identifying landscape connectivity, which refers to the physical coupling of landforms within a drainage basin, e.g. from agricultural plots to drainage channels (Bracken \& Croke, 2007), the upslope sediment source areas, the sediment routing and potential sedimentation spots are needed (Keesstra et al., 2009a; Baartman et al., 2012; Keesstra et al., 2012). This provides essential insights for planning the implementation of ST measures at the most appropriate spatial location, in an integrated way within a catchment (Zhang et al., 2010b). On-site ST measures, for example, afforestation (Keesstra et al., 2009b), vegetative strips (Pan et al., 2011), riparian vegetation (Keesstra et al., 2012; Poeppl et al., 2012) and terraces (Gebremichael et al., 2005; Garbrecht \& Starks, 2009) could be utilized in sediment source areas. While off-site ST measures for example, check dams (Abedini et al., 2012) and ponds (Fiener et al., 2005) could be implemented within drainage channels. Consequently, such on- 
and off-site ST measures could disconnect the sediment transfer linkage, which retards the transfer of sediment further downslope.

Although ST measures have significant advantages, as outlined in this review, they can also have unintended negative consequences downstream. One such impact, the 'clean water effect', occurs after the sediment has been trapped from the runoff, after which the increased erosive capacity and power of the now low sediment laden runoff can lead to scour and enhanced soil erosion, through rill and gully development (Nyssen et al., 2007a). Poor construction and lack of regular maintenance of ST measures are also issues. To maximize the effectiveness of any ST measures, regular maintenance is needed to ensure the specific ST measure used meets the design criteria for its sustainable use and to avoid structural failure (Zhang et al., 2010b). For instance, when the drainage ditch behind a ST measure is filled with sediment, the STE quickly decreases with additional pressure being placed on the structure leading to possible structural failure (Gebremichael et al., 2005; Nyssen et al., 2007b). It is important to ensure that ST measures are appropriately located as inadequately localized structure alignment can concentrate runoff at one location (Nyssen et al., 2007b) which creates large erosive potential and can generate major problems further down the landscape. Therefore, a thorough understanding of the hydrological and sediment dynamics of a catchment and its spatial alignments is needed during the design and siting of ST measures. Finally, it is also important to assess the sustainability of ST measures. Factors like subsidy and incentives were affecting ST measures sustainable use. For example, although subsidies and incentives like food-for-work or cash-for-work were used as means of short term food security and as instruments to stimulate farmers' to build ST measures, even in their own fields (Steiner \& Drechsel, 1998; Birhanu, 2003) they are affecting the measures sustainability. The ST measures dismantled in expectation of getting incentives (GTZ/IFSP, 2004). This indicates that temporary benefits are upsetting long-term and sustainable changes. Therefore, it could be important to consider such sustainability factors during measures implementation in addition to the design and siting of ST measures.

Most of the reviewed ST studies refer to research at the plot scale. However, much less is known about the integrated STE of measures at the catchment scale. Therefore, evaluating the integrated STE of ST measures at the catchment scale should be a priority for future research. Assessing the STE of all potential vegetative and structural measures, including their placement on a field-by-field basis and quantifying their integrated effect on the entire catchment is difficult both technically and financially. One method to achieve this could be by using appropriate modelling (Deletic, 2001; Verstraeten \& Poesen, 2001b; Rachman et al., 2008). The outcome of such models could be a ST plan for the catchment, as indicated schematically in Figure 3.8, where on-site measures such as terraces, grassed waterways, grass strips, etc. can be established in fields, while tree buffers or streamside (riparian) measures can be located in and along streams to trap sediments from surface runoff before being discharged into the rivers. Off-site measures, for example, sediment ponds and check dams can be built in ephemeral gullies and drainage channels to trap sediment from concentrated runoff before re-joining downstream reservoirs and lakes. On-site ST measures can trap on-site sediments in fields and off-site ST measures can trap off-site sediments in drainage channels and gullies. Sediments transported from fields without being trapped by on-site ST measures can be trapped by off-site ST measures. The integrated effect of all on-and off-site ST measures can reduce 
sediment load at the outlet of the catchment to a minimum and can be evaluated by measuring the sediment budget 'before and after' at the catchment outlet. A further advantage of using a modelling approach is the ability to assess, a-priori (i.e. before actual implementation), the effect of different spatial configurations of the various ST measures in the landscape and chose the optimal design.

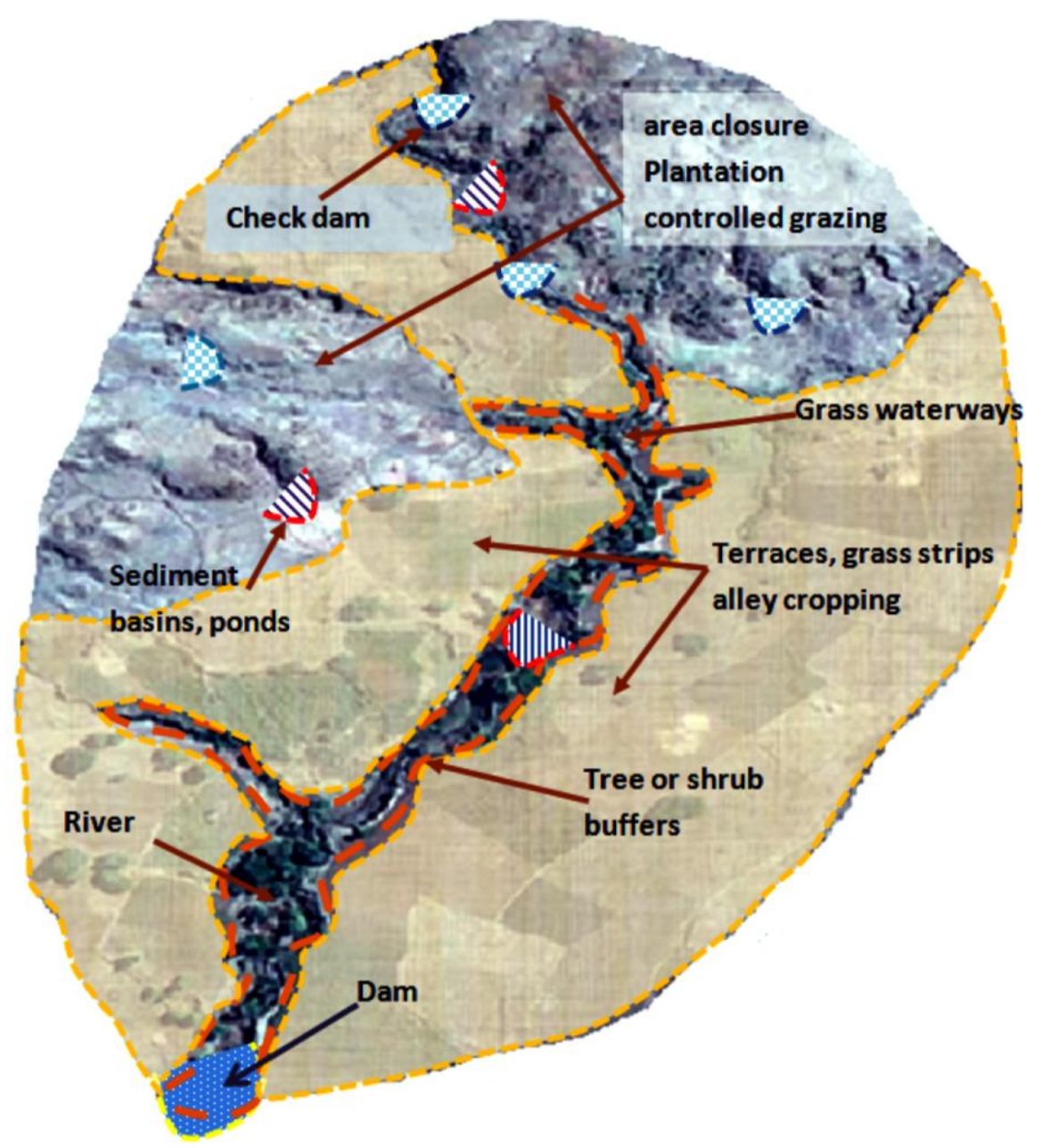

Figure 3.8 Schematic representation of integrated sediment trapping measures at a catchment scale

\subsection{Conclusions}

In this paper a large number of scientific journal articles were reviewed, field observations and stakeholder interviews were conducted in relation to on-site and off-site vegetative and structural sediment trapping (ST) measures with the results revealing that grassed waterways, terraces, grass strips, tree buffers and in-channel and riparian vegetation play an important role in reducing surface runoff velocity and in trapping sediment from agricultural fields. Check dams were found to be the preferred structural measures to reduce concentrated runoff and to trap sediment in gullies and drainage channels. Sediment ponds are also important runoff and ST measures in construction sites, drainage channels and at the edge of farmlands. 
The reviewed studies also showed that vegetation type and combinations of two or more measures (vegetative and structural) are important factors influencing sediment trapping efficacy (STE). To evaluate the STE of ST measures three approaches were identified: (i) individual approach; evaluating the STE of individual measures; (ii) Combined approach; evaluating the STE of two or more types of ST measures implemented at the same location; and (iii) integrated approach; the application of all required ST measures on their specific location within the catchment and evaluating their integrated efficacy. Almost all studies evaluated ST measures using the individual approach, which revealed a lower efficacy than the combined approach. A few studies attempted to evaluate the STE of two or more measures using an integrated approach at the catchment scale, but they were not exclusively integrated. Therefore, there is a need for further research into the use of STE of measures in an integrated approach. The integrated approach, at the catchment scale is believed to be the most effective in helping to increase the STE of ST measures and thereby reducing sediment loads at the outlet of the catchment. 


\section{Chapter 4}

\section{Sediment trapping with indigenous grass species showing differences in plant traits in NW Ethiopia}

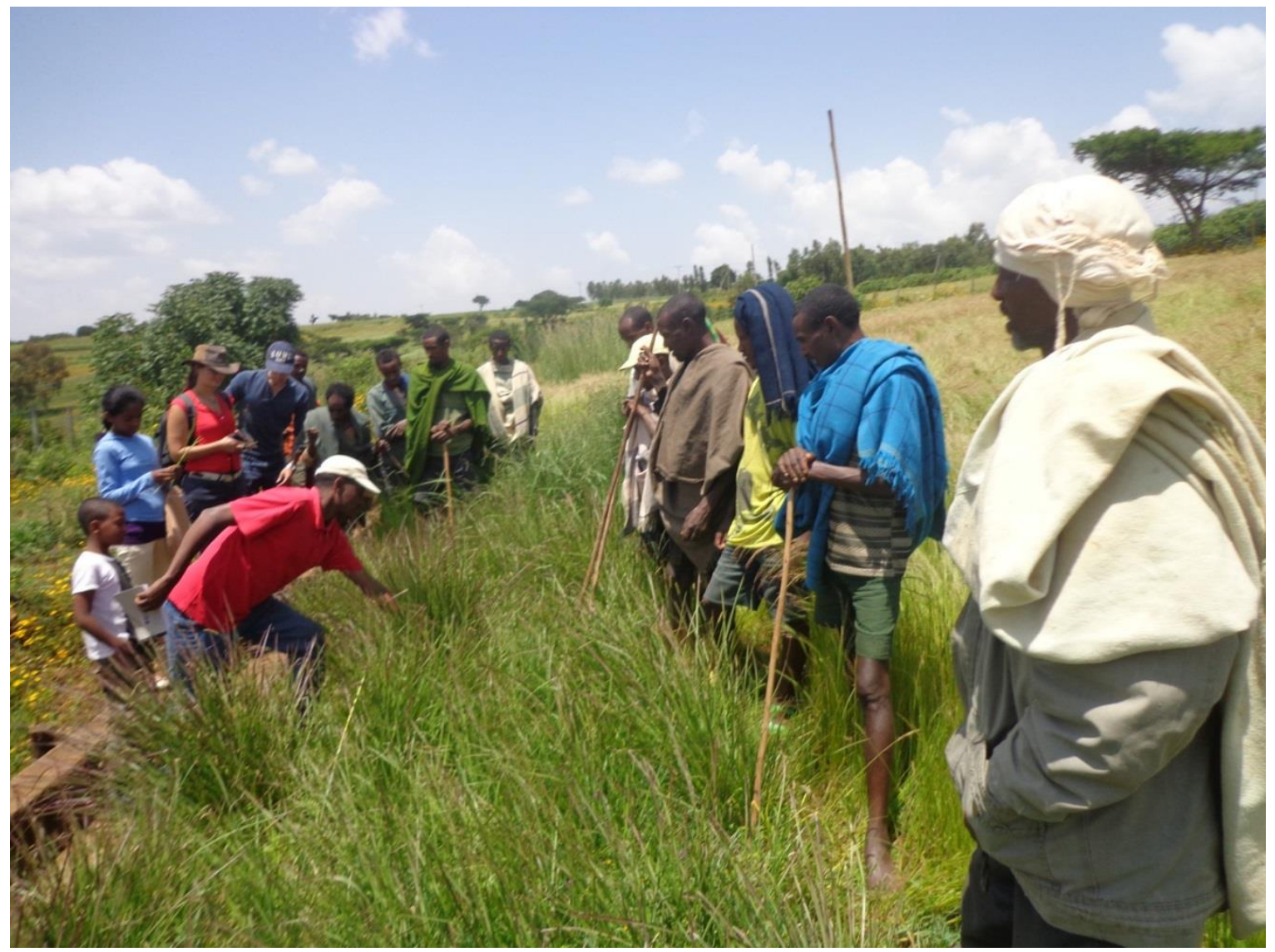

This chapter published as:

M. Mekonnen, S.D. Keesstra, C.J. Ritsema, L. Stroosnijder, J.E.M. Baartman. 2016.

Sediment trapping with indigenous grass species showing differences in plant traits in northwest Ethiopia.

Catena 147: 755-763 


\section{Sediment trapping with indigenous grass species showing differences in plant traits in NW Ethiopia}

Abstract

Soil loss from an 8\% sloping Teff field in north-western Ethiopia is significant ( 70 $\left.t \mathrm{ha}^{-1} \mathrm{y}^{-1}\right)$, and thus found to be an important source of sediment. Grass barriers showing sediment trapping efficacy (STE) are important measures in trapping sediment inside Teff fields and protecting downstream reservoirs and lakes from sedimentation. There are many indigenous grass species available that have the potential to act as sediment trapping measure when used in strips downstream of sloping crop fields. However, their STE and their key functional traits that determine their STE are not yet known. This negatively influence agricultural extension agents in disseminating conservation technology to farmers at larger scales. The indigenous grass species Desho (Pennisetum pedicellatum), Senbelet (Hyparrhenia rufa), Sebez (Pennisetum schimpri) and Akirma (Eleusine floccifolia) and one exotic species, Vetiver (Vetiveria zizanioides) were tested for two years (2013 and 2014) in $1.5 \mathrm{~m}$ wide strips below Teff fields at 8\% slope in the Debre Mewi watershed, northwest Ethiopia. The average runoff during the study was 79, 64, 69, 71, 74 and $75 / \mathrm{m}^{-2}$, with 7.0, 1.7, 2.9, 3.6, 4.5 and $5.6 \mathrm{~kg} \mathrm{~m}^{-2} \mathrm{y}^{-1}$ of sediment from the Control, Desho, Vetiver, Senbelet, Akirma and Sebez treatments, respectively. Differences in key functional traits affected the STE of the different grass barriers. Desho with the highest tiller number and density, and the second highest root length (depth) showed better STE (76\%) than the other grass species, Vetiver (59\%), Senbelet (49\%), Akirma (36\%) and Sebez (20\%). This indicates that grass barriers can be used as a soil conservation measure replacing the costly and more maintenance demanding physical structures like trenches and ridges. As a co-benefit, grass barriers provided important fresh biomass for livestock, thereby helping to reduce the feed shortage. Thus we conclude that indigenous grass species provided a practical means to reduce soil loss from Teff fields (up to 8\% slope) in the northwest Ethiopia and can be easily adopted by farmers due to their combined soil conservation and feed value.

\subsection{Introduction}

Soil erosion by water is a global problem (Morgan, 2005), however, it is more severe in developing countries (Lal, 2001; Thomaz \& Luiz, 2012), such as Ethiopia, where soil erosion of agricultural fields is leading to the loss of fertile top soil (Hurni, 1993; Zeleke, 2000) and significantly reducing crop yields (Hurni, 1993; Haileslassie et al., 2005). The problem is most critical in the Ethiopian highlands (> 1500 m a.s.I.) (FAO, 1986; Zeleke, 2000; Nyssen et al., 2004; Frankl et al., 2013) as 4\% of the highlands is seriously eroded (Kruger et al., 1996). Plot scale measurements of soil loss in the cultivated fields of the Ethiopian highlands has been estimated to be $42 \mathrm{t} \mathrm{ha}^{-1} \mathrm{y}^{-1}$ (Hurni, 1987).

Recent and more location specific studies at watershed scale estimated sheet and rill erosion losses between 19 and $79 \mathrm{t} \mathrm{ha}^{-1} \mathrm{y}^{-1}$ at Chemoga watershed (Bewket \& Sterk, 2003), and from 12.5 to $50 \mathrm{t}$ ha ${ }^{-1} y^{-1}$ at Debre Mewi Watershed (Mekonnen \& Melesse, 2011). Amare et al. (2014) also found from 26 to $71 \mathrm{t} \mathrm{ha}^{-1} \mathrm{y}^{-1}$ at plot scale in Debre Mewi watershed. Erosive tropical rains, steep slopes, extensive deforestation for fuel wood collection, expansion of cultivation into steep land areas, overgrazing, long periods of inadapted agricultural practices and high population pressure are 
important causes of such high rates of soil erosion in the north-western Ethiopian highlands (Bewket, 2002; Nyssen et al., 2004; Amsalu et al., 2007; Mekonnen et al., 2015b).

To maintain sustainable crop cultivation about $75 \%$ of the highlands need soil conservation measures (FAO, 1986). The use of on-site sediment trapping measures can reduce soil loss by promoting sedimentation within farmers' fields (Verstraeten et al., 2006; Wanyama et al., 2012; Mekonnen et al., 2014b). Vegetative measures, for example grass barriers, are among the on-site measures that play a significant role in trapping sediments from overland flow (Ritsema, 2003; Blanco-Canqui et al., 2004; McKergow et al., 2004; Stroosnijder, 2009; Wanyama et al., 2012). This is because of sediment filtration and deposition (Dillaha et al., 1989), upslope ponding (Meyer et al., 1995; Spaan et al., 2005), and decreased flow velocity and increased surface roughness, which decreases sediment transport capacity of surface runoff (Borin et al., 2005). Grass barriers also increase the efficacy of physical soil conservation structures in trapping sediment and reducing on-site soil loss when combined together (Rachman et al., 2008; Zhang et al., 2010b; Mekonnen et al., 2014b) and are less expensive and less labour intensive to implement than physical structures such as trenches and ridges. As a co-benefit, grass barriers provide livestock with feed and this can play an important role in controlling free grazing, encouraging a cut and carry system for soil conservation and in the adoption of the measures (MoA, 2001; MOARD, 2010).

The sediment trapping efficacy (STE) of many grass species is well known. For example; Lemon grass (72-92\%), Elephant grass (62-84\%), Paspalum (65-88\%) and Sugarcane (56-82\%) in Uganda (Wanyama et al., 2012); Vetiver grass (65\%) in Australia (McKergow et al., 2004); Brome grass (7085\%) (Robinson et al., 1996) and Switch grass (92\%) (Lee et al., 2000) in the USA; Centipede grass (24-73\%) in Japan (Shiono et al., 2007); Black rye (42-69\%) in China (Pan et al., 2010) and Vetiver (62\%) and Desho (43\%) in the lowland part of Ethiopia (Welle et al., 2006). The STE of Desho grass was tested by Welle et al. (2006) in the lowland part of Ethiopia but not in the highlands where it performs best (MOARD, 2010). There are in fact many grass species that could potentially serve as vegetative barriers in the northwest Ethiopian highlands but have not been studied for their STE including locally used grass species Desho (Pennisetum pedicellatum), Senbelet (Hyparrhenia rufa), Sebez (Pennisetum schimpri) and Akirma (Eleusine floccifolia). Traditionally, these four grass species are being used by a majority of Ethiopian farmers by planting them on their lower field edges in 1-1.5 $\mathrm{m}$ wide strips.

Investigating the STE of these indigenous grass species in northwest Ethiopia will provide valuable information for local farmers, agricultural extension agents and researchers. To facilitate the extrapolation of results to other contexts and species, attention should be paid to key functional traits. Grass morphological characteristics such as number of tiller, density and root depth affect STE (Pearce et al., 1997; Abu-Zreig et al., 2004; Spaan et al., 2005; Montakhab \& Yusuf, 2011; Burylo et al., 2012; Wanyama et al., 2012) found that dense vegetation barriers promote sedimentation reducing flow velocity and building up backwater upslope. STE is influenced by the type and density (Abu-Zreig et al., 2004), and density and distribution (Montakhab \& Yusuf, 2011) of the grass barrier. Plant roots increase the resistance of soils to erosion (Reubens et al., 2007) and help improve soil permeability, increasing soil infiltration and thus decreasing runoff volume, thereby promoting 
sedimentation. Furthermore, a plant with deep roots can access water deep below the surface, which increases infiltration and reduce runoff, thus increasing sedimentation (Ohare et al., 2016).

This study evaluated the STE of four indigenous grass species (Desho, Senbelet, Akirma and Sebez) and one exotic grass species (vetiver), to determine the differences in plant traits, in northwest Ethiopia. The objectives were to (i) evaluate the STE of these grass species at the field level, and (ii) determine the differences in STE through the key functional traits of these grasses (root depth, tiller number and density). Finally, an assessment of the chance of adoption of these plants by farmers in northwest Ethiopia, based on social and economic considerations, is presented.

\subsection{Materials and methods}

\section{Experimental site}

The study was conducted over a two year period using experimental plots located at an elevation of $2300 \mathrm{~m}$ a.s.l., with an average slope of $8 \%$ (ranging from 7-9\%), in the Debre Mewi watershed, in the upper Blue Nile Basin, northwest Ethiopia (327865 m N and 1256370 m E; Adindan_UTM_Zone_37N; Figure 4.1). The average annual rainfall over these two years was $1080 \mathrm{~mm}(1105 \mathrm{~mm}$ in 2013 and $1055 \mathrm{~mm}$ in 2014). About $80-90 \%$ of the rainfall falls in the main rainy season (Kiremt), which starts in June and extends to September, but is preceded and followed by one month of low and dispersed rains. Mean annual minimum and maximum temperatures of the site are $8.7{ }^{\circ} \mathrm{C}$ and $25.4{ }^{\circ} \mathrm{C}$, respectively.

The Nitosol soil type present has a predominantly clay texture (Mekonnen \& Melesse, 2011; Mekonnen et al., 2015c) containing 12\% stoniness. According to Bationo et al. (2006), Nitosols are deep, well drained and red tropical soils with a clay-rich subsoil, characterized by good soil structure. They are general considered to be fertile soils and are found in 200 million ha worldwide, with more than half of all Nitosols present in tropical Africa, especially in the highlands ( $>1000 \mathrm{~m}$ ) of Ethiopia, Kenya, Zaire and Cameron.

\section{Field experiment}

The experiment was conducted during the 2013 and 2014 seasons on a natural slope, which was treated similarly as the surrounding farmland (Figure 4.2). Six runoff plots (6 m wide x $29.5 \mathrm{~m}: 177$ $\mathrm{m}^{2}$ ) were constructed according to the Soil Conservation Research Programme (SCRP) plots used in Ethiopia (Herweg \& Ludi, 1999). Teff (Eragrostis teff, E. abysainica) is the dominant indigenous crop and used as the test crop. Teff is a staple crop in Ethiopia comprising $>43 \%$ of the total crop production area in Amhara Regional State (CSA, 1999). Teff was planted in the first week of July and harvested in December. Broadcasting was applied to sow the crop (Teff), which is a common planting method in the area. To reduce sediment loss variability due to crop type, the same crop was used in both experimental years without rotation. 


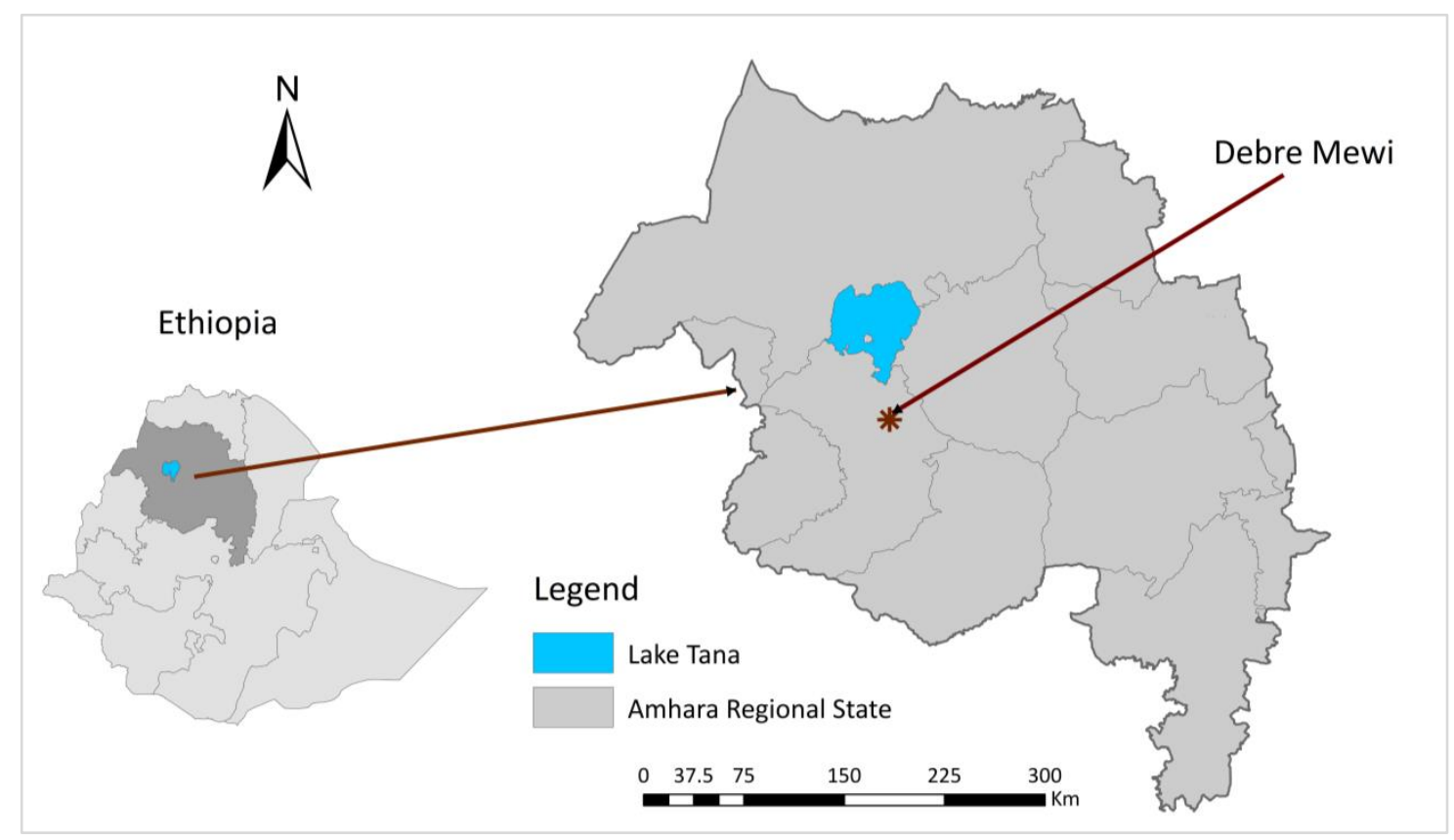

Figure 4.1 The Debre Mewi watershed in Amhara Regional State of Ethiopia

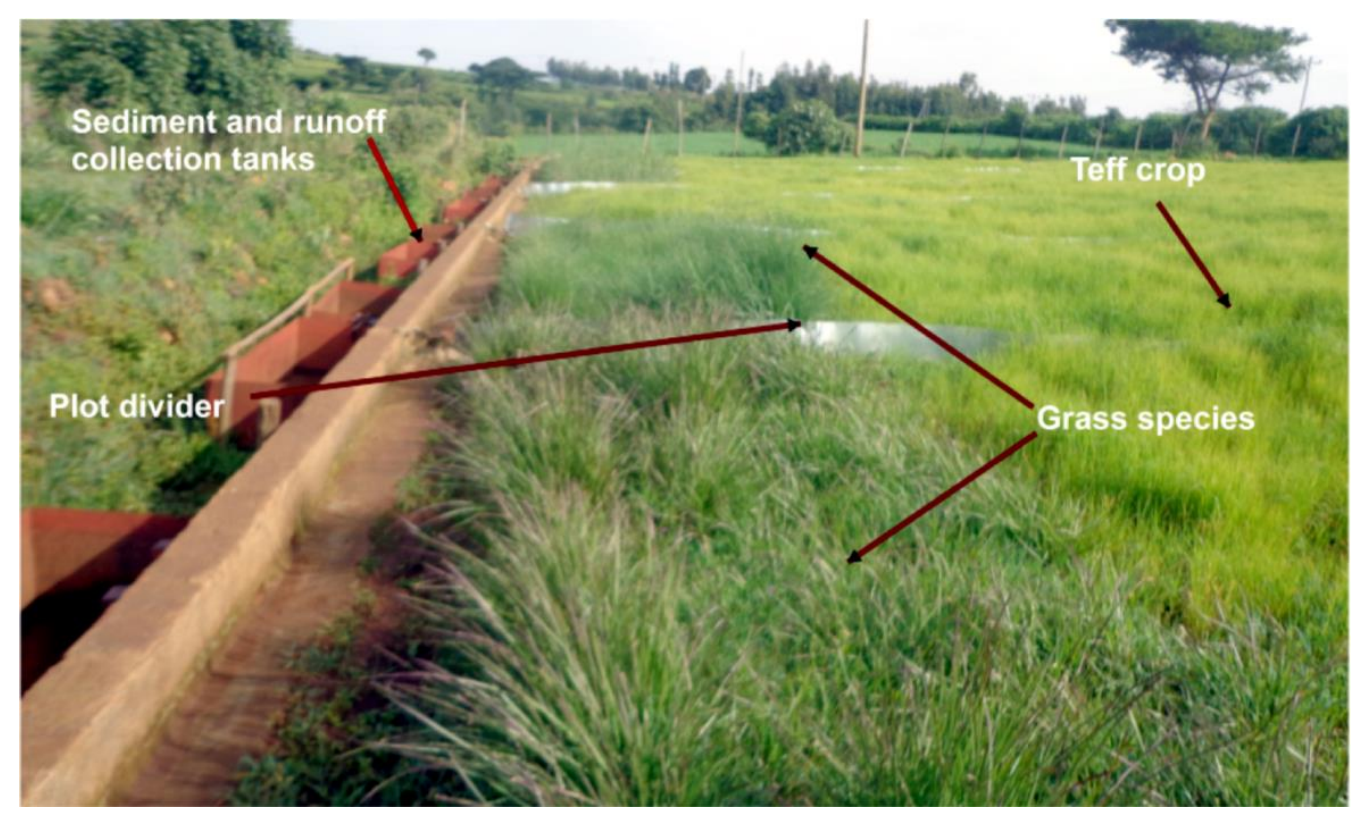

Figure 4.2 Field experimental setup with Teff as food crop and $1.5 \mathrm{~m}$ wide grass barriers and runoff and sediment collection tanks, Debre Mewi watershed, Ethiopia

Grass strips ( $1.5 \mathrm{~m}$ wide) were planted at the end of each plot except for the control. Most farmers in the area plant grass species with widths of 1.0-1.5 m on the edge of their fields. The maximum width $(1.5 \mathrm{~m})$ was used in our experiment assuming that wider strips can trap sediment more efficiently (Abu-Zreig et al., 2004; Wanyama et al., 2012).

Tanks ( $0.5 \mathrm{~m}$ height $\times 1 \mathrm{~m}$ width $\times 1.5 \mathrm{~m}$ length) were positioned at the lower end of each experimental plot to collect sediment-laden runoff. Additional tanks were established connected to 
the first tank to collect the overflow runoff and sediment. To isolate the experimental treatments from each other and from the surrounding fields, $40 \mathrm{~cm}$ height corrugated iron fencing was installed around each plot.

Due to time and resource constraints this experiment was not replicated spatially. Therefore, great care was taken to select a site with uniform slope, soil type, texture, rainfall and land cover in order to have 6 similar plots to be arranged in sequence. Ellis et al. (2006), Shiono et al. (2007) and Leguedois et al. (2008) demonstrated that any likely error in the surface water budget due to spatial variation between treatment sequences was likely to be smaller than the measurement errors.

\section{Grass morphological traits}

Five grass species were selected for this study; four locally dominant indigenous grass species Desho (Pennisetum pedicellatum), Senbelet (Hyparrhenia rufa), Sebez (Pennisetum schimpri) and Akirma (Eleusine floccifolia) of the northwest Ethiopia and one exotic but well adapted grass species, Vetiver (Vetiveria zizanioides). All species are perennials, are suitable for the rainfall and altitude of the Debre Mewi watershed and are already known and used by farmers. The morphological characteristics and elevation and rainfall ranges to which these grass species are adapted, are presented in Table 4.1.

Table 4.1 Available information of the selected barrier grass species used in the 2013-2014 trials at Debre Mewi, Ethiopia.

\begin{tabular}{|c|c|c|c|c|c|}
\hline \multirow{2}{*}{$\begin{array}{l}\text { Grass } \\
\text { species }\end{array}$} & Elevation & Rainfall & Height & Fodder & \multirow[t]{2}{*}{ References } \\
\hline & $\mathrm{masl}$ & $\mathrm{mm}$ & $\mathrm{cm}$ & & \\
\hline Desho & $\begin{array}{l}1500-2800, \\
\text { (perform best 1700- } \\
2500 \text { ) }\end{array}$ & $1000-1500$ & $90-120$ & +++ & $\begin{array}{l}\text { Welle et al. (2006); MOARD (2010); } \\
\text { NBDC (2013) }\end{array}$ \\
\hline Senbelet & $0-2000$ & $600-1400$ & $60-240$ & ++ & Skerman and Riveros. (1990) \\
\hline Sebez & $1600-3100$ & No data & Up to 120 & + & Skerman and Riveros. (1990) \\
\hline Akirma & $1800-3100$ & 900 & $120-150$ & ++ & Dagnachew et al. (2014) \\
\hline Vetiver & $1000-3000$ & $750-2000$ & Up to 200 & ++ & $\begin{array}{l}\text { MOARD (2010); Truong and Loch } \\
\text { (2004) }\end{array}$ \\
\hline
\end{tabular}

Palatability of the grass species from farmers experience; high palatability (+++); palatable (++); low palatability $(+)$

The grasses, splits containing 3-5 tillers, were planted in rows with $30 \mathrm{~cm}$ between the rows and at $15 \mathrm{~cm}$ spacing within rows (MoA, 2001; Welle et al., 2006; Oshunsanya, 2013). There were five rows within the $1.5 \mathrm{~m}$ strip. Some of the grass species were collected in farmers' fields and some obtained from a local nursery. During the first year (2013), the grass species were planted at the end of April. Data collection started two months after planting at the beginning of July when the grasses were well established and ended at the end of September. The first years' data collection was finalized when the rainy season ended; grasses were harvested and they re-vegetated during the next rainy season (July, August and September) for the second year (2014) of data collection. 
To evaluate the key plant functional traits root length, tiller number and density were determined in the field. To assess the average root length per split, 20 grass splits were taken, carefully dugout and measured from each species. To find the average number of tillers per split, 16 splits were sampled randomly from each species. To calculate tiller density $\left(\right.$ in $\mathrm{m}^{2}$ ), the total number of tillers was divided by the total area covered by the grass barriers.

\section{Sediment data collection and sediment trapping efficacy (STE) calculation}

Daily rainfall data was collected using a rain gauge, while daily runoff was measured after each rainfall event. Daily runoff was summed up into annual runoff. To estimate sediment loads, one-litre runoff samples were collected from the sediment collection tanks after each runoff producing rainfall. Before taking samples, the trapped runoff and sediment in the tanks was stirred thoroughly to make the samples representative. Over the two years, 54 one-litre samples from each treatment, amounting to 324 samples being collected, dried and weighed. The dry sediment mass from the runoff sample $\left(\mathrm{g} \mathrm{I}^{-1}\right)$ was used to quantify daily sediment loss using the daily total runoff volume. The sum of daily sediment losses provided the annual soil loss.

To estimate the sediment trapping efficacy (STE,) sediment measured at the outlet of the control treatment was considered as inflow into the grass strip, while sediment measured at the outlet of a grass barrier was considered as outflow sediment. STE was then calculated using Eq. 4.1 (Coyne et al., 1995; Verstraeten \& Poesen, 2000).

$$
S T E=\frac{\left(S_{\text {inflow }}-S_{\text {outflow }}\right)}{S_{\text {inflow }}} * 100
$$

Where: $S T E$ is sediment trapping efficacy (\%); $S_{\text {inflow }}$ is total seasonal sediment mass measured at the outlet of the control plot $(\mathrm{kg})$ and $S_{\text {outflow }}$ is total seasonal sediment mass measured at the outlets of each treated plot $(\mathrm{kg})$.

\subsection{Results}

\section{Effect of grass barriers on runoff reduction and sediment trapping}

The average inflow and outflow runoff over the two years from the experimental plots for each species is given in Figure 4.3. While the control resulted in the overall highest runoff $\left(14.0 \mathrm{~m}^{3}\right)$, the least runoff from the grassed plots was recorded from Desho $\left(11.3 \mathrm{~m}^{3}\right)$ and the most runoff from Sebez $\left(13.2 \mathrm{~m}^{3}\right)$. Overall, Desho, Vetiver, Senbelet, Akirma and Sebez reduced runoff by $2.7 \mathrm{~m}^{3}(19 \%)$; $1.9 \mathrm{~m}^{2}(14 \%) ; 1.4 \mathrm{~m}^{2}(10 \%) ; 1.0 \mathrm{~m}^{3}(7 \%)$ and $0.8 \mathrm{~m}^{3}(6 \%)$, respectively. 


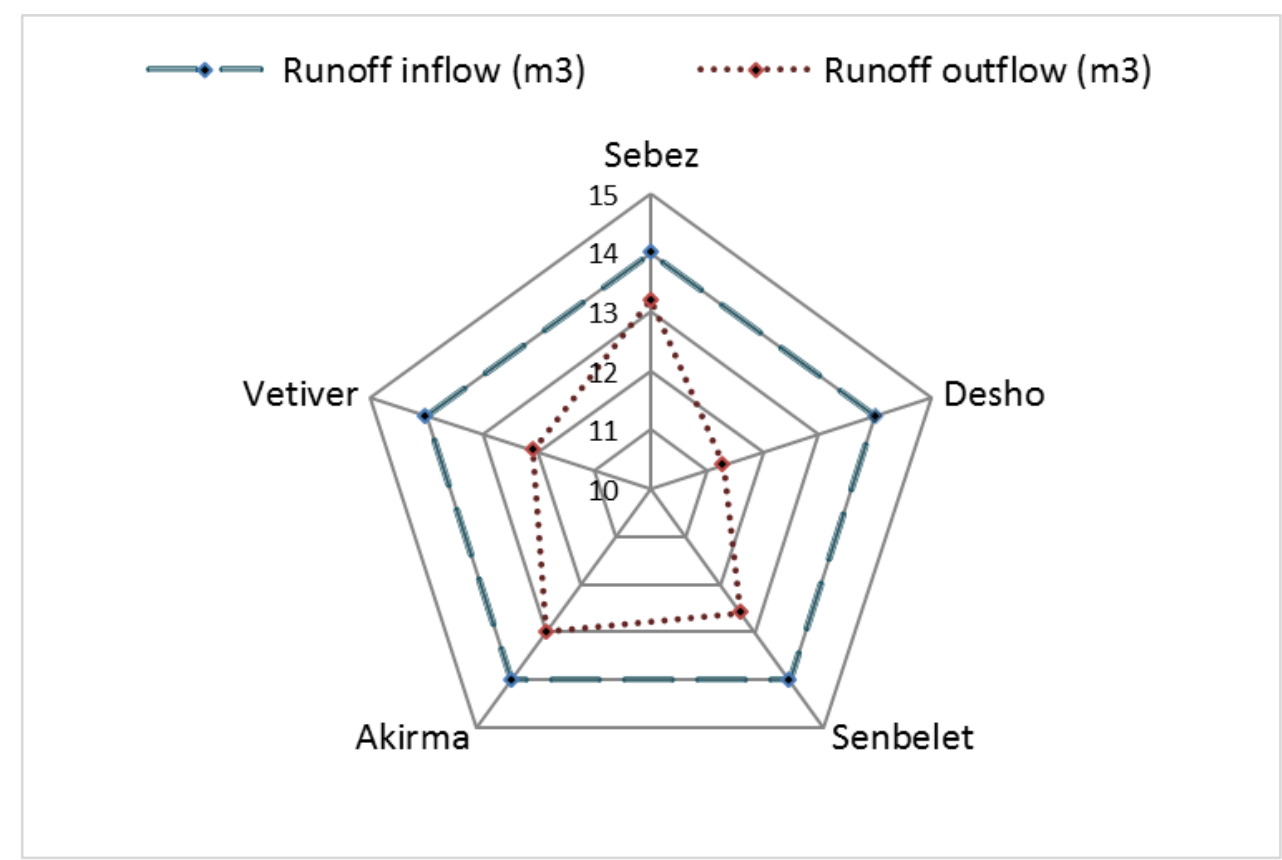

Figure 4.3 Radar diagram showing inflow and outflow runoff records from each experimental plot

Sediment concentration and the corresponding STE recorded over the two years is given in Figure 4.4. The lowest sediment concentrations were from the Desho $\left(27 \mathrm{gl}^{-1}\right)$ plot, which were three times lower than the control $\left(93 \mathrm{~g}^{-1}\right)$, while the highest was from the Sebez $\left(71 \mathrm{~g}^{-1}\right)$ plot. Sediment concentration from the Vetiver $\left(42 \mathrm{gl}^{-1}\right)$ was 2 times lower from the control readings. Given the rapid growth of the Teff crop, there is a large difference in sediment concentration at the beginning of the season and at the end. Comparing 10 sediment samples at the beginning with 10 at end of the rainy seasons for the Control plot, revealed high sediment concentrations $\left(189 \mathrm{~g} \mathrm{l}^{-1}\right)$ at the beginning of the season versus very low concentration $\left(14 \mathrm{gl}^{-1}\right)$ at the end.

The lowest sediment loss was recorded from Desho $(306 \mathrm{~kg}$ ) with most sediment loss recorded from Sebez $(996 \mathrm{~kg}$ ), while the Control $(1251 \mathrm{~kg}$ ) had the highest overall sediment loss (Figure 4.4). Sediment loss was 4 times lower in Desho plot and 2 times lower in Vetiver plot relative to the control. This implies that Desho grass trapped four and two times more sediment than Sebez and Akirma, respectively. Vetiver and Senbelet also trapped three and two times more sediment than Sebez and Akirma, respectively. The resulting average STE (in \%) was 76, 59, 49, 36 and 20 for Desho, Vetiver, Senbelet, Akirma and Sebez, respectively (Figure 4.4).

\section{Functional traits of grass barrier species}

Figure 4.5 shows the four indigenous and one exotic barrier grass species used. The grass barriers revealed some distinct variations in the morphological characteristics in root length, tiller number and density (Table 4.2). Desho had the highest number of tillers and highest tiller density whereas Sebez displayed the lowest. Vetiver had the highest root length whereas Sebez had the lowest. Desho had a fast lateral spreading growth pattern compared to the other grass species and covered the free space between rows and within rows in a short period of time. 
The functional traits of the grasses appear to influence the STE of the grass barriers (Figure 4.6). STE revealed strong correlation with tiller density $\left(R^{2}=0.89\right)$, number of tillers $\left(R^{2}=0.85\right)$ and root length $\left(R^{2}=0.73\right)$.

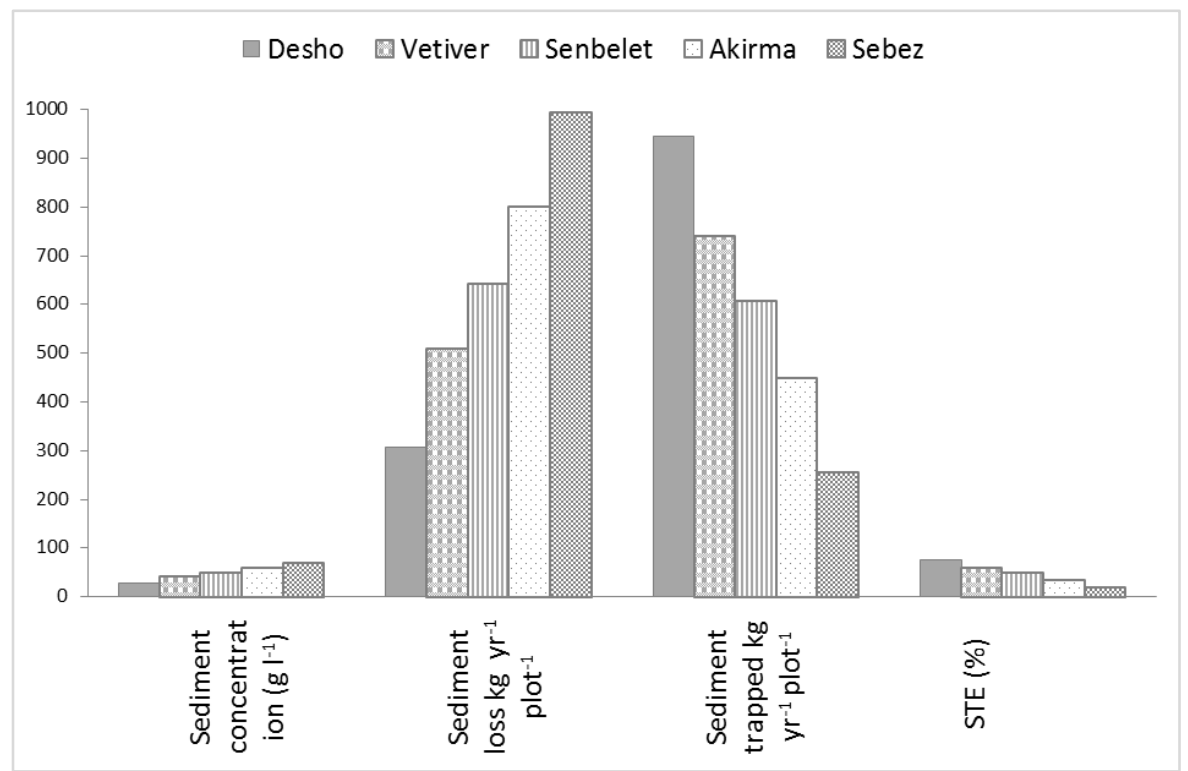

Figure 4.4 Mean (2013-2014) annual sediment concentration; -loss; -trapped and STE of the grass barriers in Debre Mewi watershed, north-western Ethiopian highlands

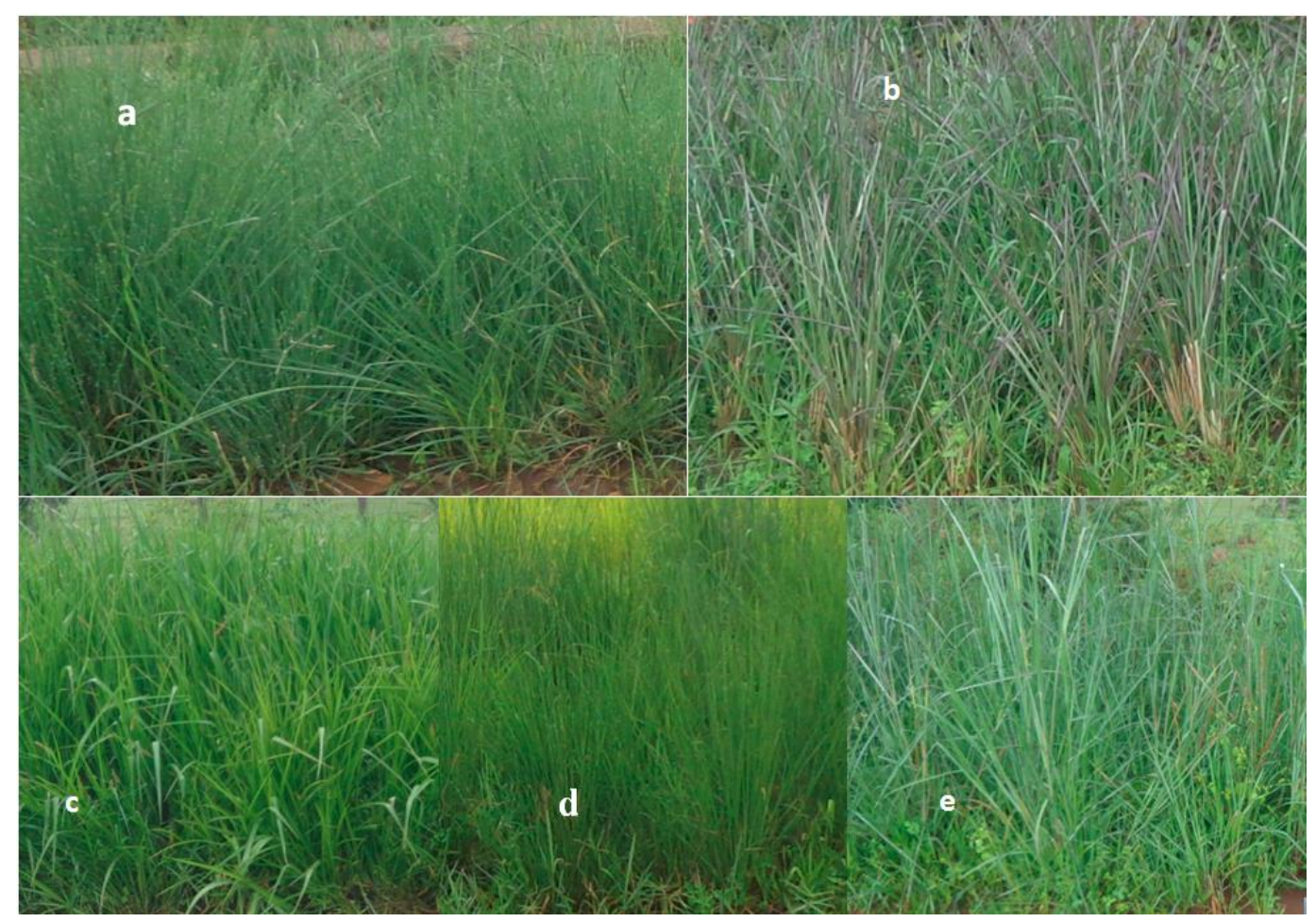

Figure 4.5 Barrier grass species evaluated for their key plant functional traits for STE: Akirma (a), Vetiver (b), Desho (c), Sebez (d) and Senbelet (e) (Photos by Mulatie Mekonnen) 
Table 4.2 Functional traits (average of 2013 and 2014 growing seasons) of tested barrier grass species, Debre Mewi watershed, Ethiopia

\begin{tabular}{llll}
\hline Grass barrier & Root length $(\mathrm{cm})$ & Av. number of tillers $\left(\mathrm{split}{ }^{-1}\right)$ & Tiller density $\left(\mathrm{m}^{-2}\right)$ \\
\hline Desho & 61 & 41 & 92 \\
Vetiver & 64 & 35 & 78 \\
Senbelet & 51 & 36 & 81 \\
Akirma & 46 & 32 & 72 \\
Sebez & 39 & 30 & 67 \\
\hline
\end{tabular}
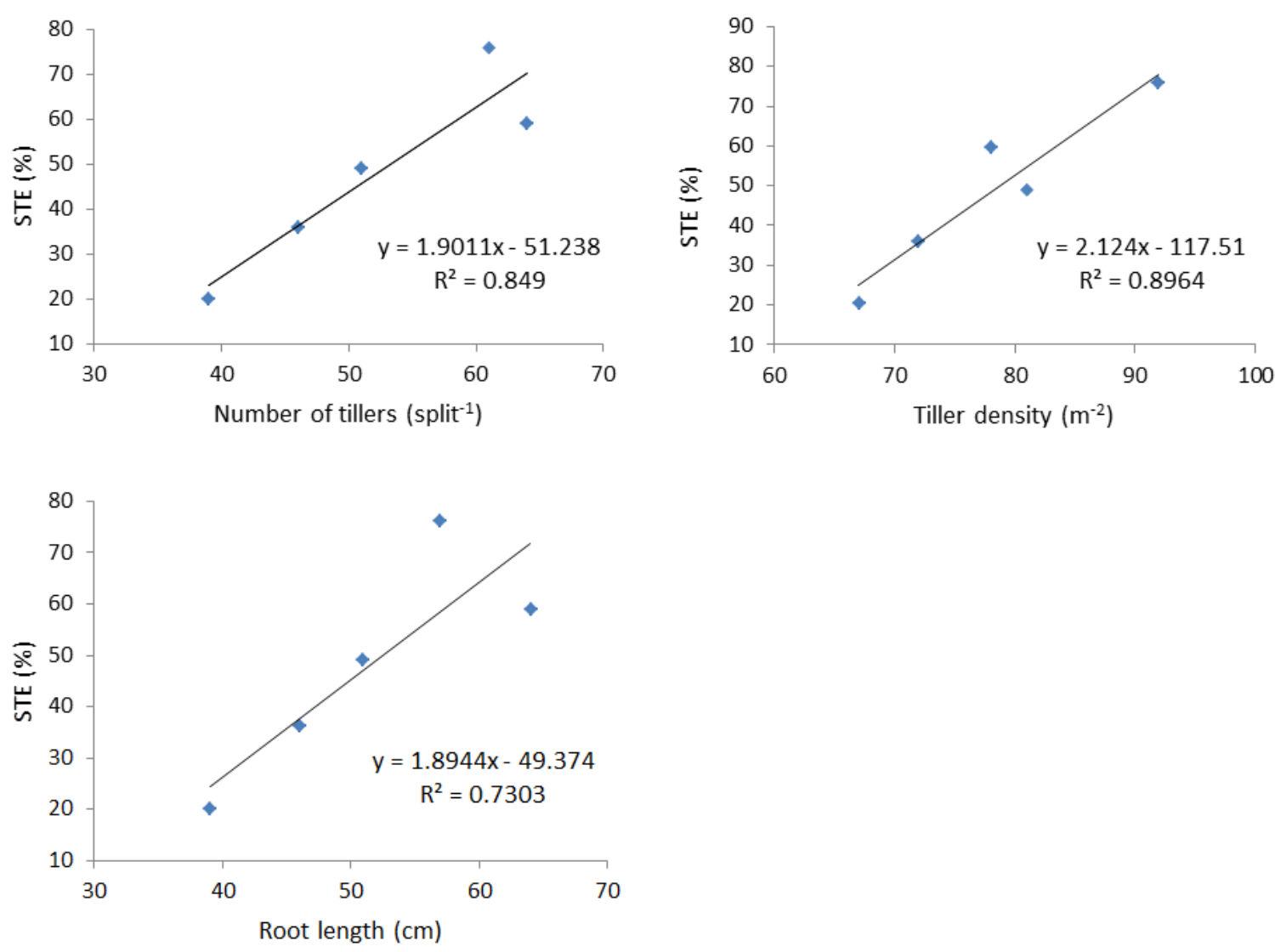

Figure 4.6 Relations of STE with number of tiller (a), tiller density (b) and root length (c)

\subsection{Discussion}

\section{Sediment trapping efficacy (STE)}

In this study, the STE of Desho (76\%) was the highest followed by Vetiver (59\%), Senbelet (49\%), Akirma (36\%) and Sebez (20\%). Due to its fast lateral spreading growth pattern, large number of tillers and high tiller density, Desho covered the free space between rows and within rows rapidly, which contributed to its high STE compared with the other grass species. In line with this result, Wanyama et al. (2012), found lemon and paspalum grass revealed greater STE than elephant grass and sugar cane because of their spreading growth pattern. Because of their slow lateral spreading and more vertical growth pattern, which causes low coverage of the free space between rows and 
within rows that allows the sediment to pass, Vetiver and Senbelet revealed lower STEs than Desho. The slow growth nature of Akirma and Sebez influences their STE considerably.

Our finding for the STE of Desho (76\%) was much higher than the $43 \%$ reported by Welle et al. (2006) for a low land area of Ethiopia at a lower altitude (1650 $\mathrm{m}$ a.s.l.) and lower annual rainfall $(661 \mathrm{~mm})$ than in this study. These difference in altitude and rainfall influence the growth and tillering capacity of the grass barrier. In our study, Desho grass performs best at the higher altitude and higher rainfall, which is in line with (MOARD, 2010). The STE of Vetiver grass was $59 \%$, which is comparable with the $62 \%$ reported by Welle et al. (2006) in Ethiopia and the 65\% reported by Mckergow et al. (2004) in Australia.

\section{Key functional traits of barrier grass and STE}

In this study, tiller density and STE showed a good relationship $\left(R^{2}=0.89\right)$ with increasing tiller density STE increases; which agrees with Abu-Zreig et al. (2004) and Montakhab and Yusuf (2011). STE also showed a good correlation with the number of tiller $\left(R^{2}=0.85\right)$, which is in line with Lambrechts et al. (2014) who found that STE increases with an increase in the tillering capacity of vegetative barriers.

In this study no backwater effects was observed upslope of the grass barriers and hence sedimentation was largely due to sediment filtration by, and deposition in, the grass barriers. This result agrees with Dillaha et al. (1989) who also found that grass barriers played a significant role in trapping sediment from surface runoff because of sediment filtration and deposition. In this study deep rooted grass species revealed a good positive correlation with STE $\left(R^{2}=0.7\right)$, which is in line with Ohare et al. (2016) that deep rooted plants increase sedimentation.

\section{Importance of soil loss reduction by grass barriers}

On-site sediment trapping measures can trap sediment and thus limit sediment export from agricultural fields (Verstraeten et al., 2006; Lambrechts et al., 2014; Mekonnen et al., 2014b). Grass barriers are among the many on-site measures that play a significant role in trapping sediments from overland flow (Ritsema, 2003; Blanco-Canqui et al., 2004; McKergow et al., 2004; Stroosnijder, 2009; Wanyama et al., 2012). In this study, grass barriers reduced sediment concentration on a Teff field considerably. Compared with the control plot $\left(93 \mathrm{~g} \mathrm{I}^{-1}\right)$, Desho, Vetiver, Senbelet, Akirma and Sebez reduced sediment concentration (in $\mathrm{g}^{-1}$ ) to $66 ; 51 ; 43 ; 33$ and 22 , respectively.

The average soil loss during the study due to sheet erosion from the un-grassed $8 \%$ sloping Teff field was found to be $70 \mathrm{t} \mathrm{ha}^{-1} \mathrm{y}^{-1}$ (control treatment). Grass barriers trapped a lot of sediment and reduced soil loss substantially. Desho showed the highest reduction with $53 \mathrm{t} \mathrm{ha}^{-1} \mathrm{y}^{-1}$ while Sebez had the lowest at $15 \mathrm{t} \mathrm{ha}^{-1} \mathrm{y}^{-1}$. Vetiver, Senbelet and Akirma reduced 42; 34 and $26 \mathrm{t} \mathrm{ha}^{-1} \mathrm{y}^{-1}$, respectively. This indicates that grass barriers can be used as an effective soil conservation measure in replacing the costly and more maintenance demanding physical structures like trenches and ridges, as also noted by (MOARD, 2005), for fields up to $8 \%$ slope. An important advantage of vegetative measures over physical structures is the use of grass as feed. Moreover, Desho and Vetiver grasses are not affected by nor harbour rats unlike the case in physical structures such as stone bunds. 
Sediment trapping was found to be effective when structural and vegetative measures combined together (Mekonnen et al., 2014b). Erktan et al. (2013) investigated the role of morphological diversity of plant barriers in sediment trapping and found that grass barriers performed best in trapping sediment however, the morphological diversity was significantly impaired by STE. On the contrary, Lee et al. (2000) found that the combined STE of Switch grass-woody vegetation (92\%) was higher than the switch grass alone (70\%) and according to Knight et al. (2010), even though natural remnant forests showed substantial STE (80\%), the addition of an adjacent grass barrier further reduced sediment load entering streams with a STE of $100 \%$. In this study, grass barriers showed substantial STEs when evaluated in a monospecific (individual) test and further study has been recommended to evaluate the STE of the grass barriers in a plurispecific (combined) approach.

\section{Chances for adoption by farmers}

The biggest challenge for soil conservation experts is the adoption of conservation measures by farmers. Lack of feed for animals is an important problem in the north-western Ethiopian highlands. As a co-benefit, grass barriers can provide livestock feed and this can play an important role in adoption of the measure. Improved feed supply can help to control free grazing and encourage a cut and carry system for soil conservation (MoA, 2001; MOARD, 2010). According to Engdayehu et al. (2015), at Debre Mewi watershed the major source of fodder is crop residue and hay collected during harvesting. During the rainy season edible weed species from the crop fields and during the dry season crop residues (mainly teff and maize straws) and grass collected during October and December are the main sources of livestock feed. In our study, the evaluated grass species were found to be important sources of livestock feed in addition to trapping sediment and reducing soil loss. Desho, Senbelet, Akirma, Vetiver and Sebez provided 132, 106, 76, 69 and $51 \mathrm{t} \mathrm{ha}^{-1} \mathrm{y}^{-1}$ fresh biomass, respectively. A field day was organized for farmers living around the study area and they visited the experiment and indicated Desho as their first priority for livestock feed. Leaf softness and biomass production were their most important criteria.

To reduce the bias that often results when using artificial rainfall, this study was conducted at field level with a considerable investment in collecting runoff and sediment data after each natural rainfall event during two growing seasons (2013 and 2014). Due to resource constraints, this experiment was not replicated spatially. Great care was therefore taken to select a site with similar conditions (soil type, slope, rainfall and land cover) and set the treatment in sequences. We therefore regard our measurements to be representative of the runoff and sediment processes observed during the experiment. Ellis et al. (2006) and Leguedois et al. (2008) demonstrated that any likely error in the surface water budget due to spatial variation between treatment sequences was likely to be smaller than the measurement errors. 


\subsection{Conclusions}

Soil loss from an $8 \%$ slope Teff field was measured at $70 \mathrm{t} \mathrm{ha}^{-1} \mathrm{y}^{-1}$. Erosion was high at the beginning of the rainy season as a result of repeated ploughing (fine seed bed preparation) and lack of a crop cover. The use of $1.5 \mathrm{~m}$ wide strips of local grasses showed promising results in trapping sediment. Desho grass performed best and reduced soil loss with $53 \mathrm{t} \mathrm{ha}^{-1} \mathrm{y}^{-1}$ with a Sediment Trapping Efficacy (STE) of 76\%. Differences in key functional traits affected the STE of the different grass barriers. Desho with the highest tiller number and density, and the second highest in root length revealed better STE than the other grass species, Vetiver (59\%), Senbelet (49\%), Akirma (36\%) and Sebez (20\%). The fast lateral spreading growth nature, leading to covering the free space between rows and within rows within a short period of time helps Desho grass to perform best. As a co-benefit, grass barriers provided fresh biomass for livestock helping to reduce the forage problem. Thus we conclude that Indigenous grass species provided a practical means to reduce soil loss from Teff fields (up to $8 \%$ slope) in the north-western highlands of Ethiopia and seemed to be easily adopted by farmers due to its feed value.

Determining the STE of grass barriers and evaluating key functional traits that influence STE is important, both for soil conservation experts to disseminate the technology with evidence, for researchers as a source of scientific information and for farmers to use the grass barriers as a sediment trapping measure. This study is the first to test the effectiveness of Desho, Senbelet, Akirma and Sebez under sheet erosion conditions and to give attention to their key functional traits in the north-western Ethiopian highlands. However, further study is recommended on higher slopes (> 8\%) and under concentrated flow conditions with different strip widths. 


\section{Chapter 5}

\section{Evaluating sediment storage dams: structural off-site sediment trapping measures in NW Ethiopia}

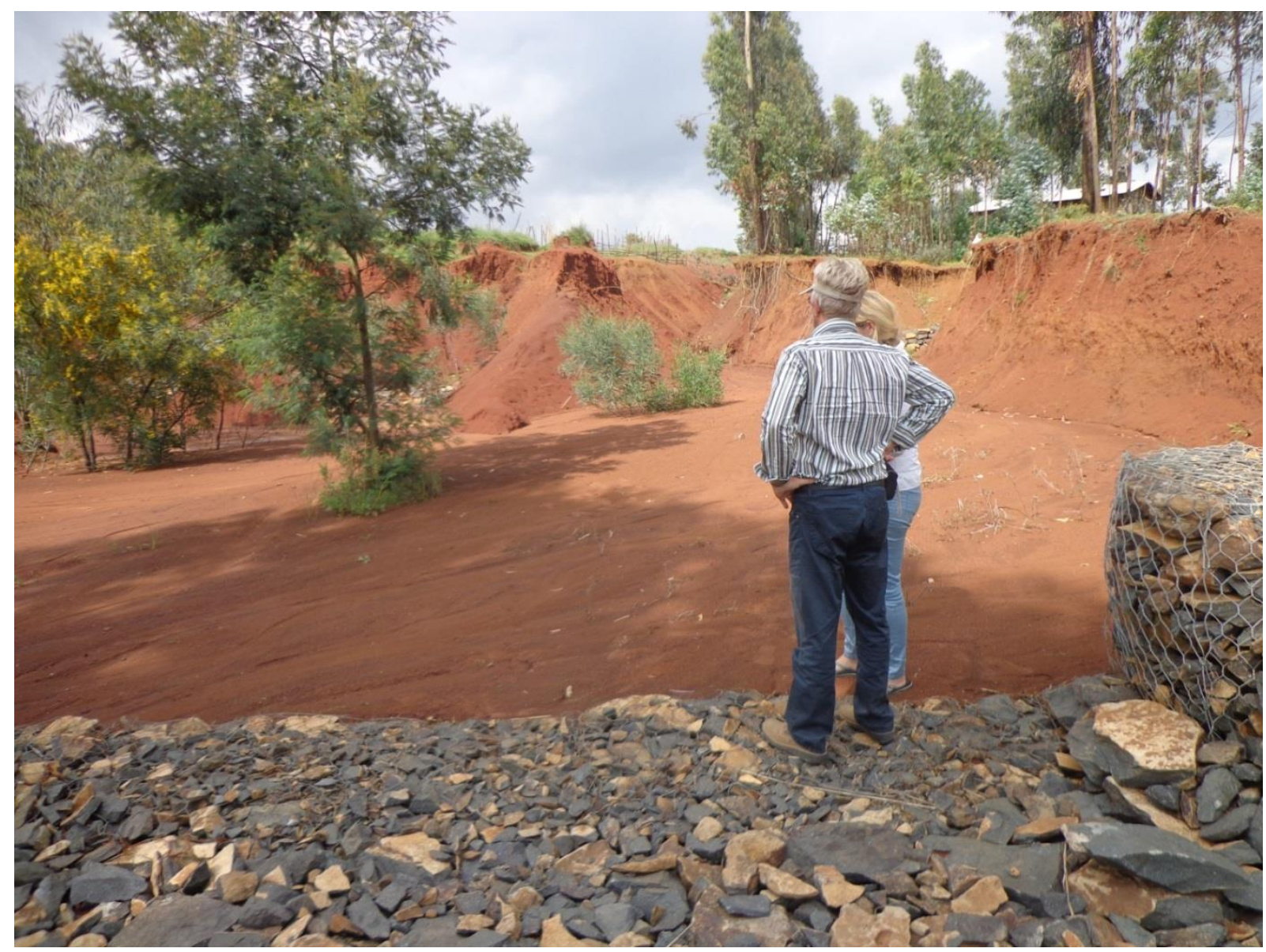

This chapter is published as:

M. Mekonnen, S.D. Keesstra, J.E.M. Baartman, C.J. Ritsema, A.M. Melesse. 2015.

Evaluating sediment storage dams: structural off-site sediment trapping measures in NW Ethiopia. Cuadernos de Investigacion Geografica 41: 7-22.

DOI: 10.18172/cig.2643. 


\section{Evaluating sediment storage dams: structural off-site sediment trapping measures in NW Ethiopia}

\section{Abstract}

Reservoir and lake sedimentation is a vital problem in Ethiopia. Constructing small and medium size dams at the outlets of sub-catchments within the larger catchment helps to reduce the transport of sediment to downstream man-made reservoirs constructed at the outlet of the catchment or natural lakes. This study assessed the sediment trapping efficacy (STE) of sediment storage dams (SSDs) built at the outlets of eight small sub-catchments in northwest Ethiopia, as an off-site sediment trapping measure. Satellite imagery and topographic maps were used to assess land use/land cover and delineate the boundaries of sub-catchments. In the field, trapped sediment by SSDs was measured directly, as well as in-and outflow of suspended sediment with which the STE of each SSD was estimated. Sediment yield of each sub-catchment was calculated from the measured trapped sediment and estimated suspended sediment loss. Results show that SSDs trapped an average of $1584 t y^{-1}$ of the inflow sediment and catchment specific sediment yield ranged from 8.6-55 $t$ ha $a^{-1} y^{-1}$. Two representative SSDs constructed from gabion and stone were evaluated with regard to their STE. Results showed that their efficacy was $74 \%$ and $67 \%$ for the gabion and stone SSD, respectively. In general, although SSDs might be costly for small scale farmers and have a relatively short life span depending on their size, they are promising off-site structural measures to trap significant amounts of sediment at the outlets of subcatchments and subsequently reducing sediment movement to downstream reservoir or lakes.

\subsection{Introduction}

On-site soil erosion and off-site sedimentation are natural phenomena in landscape formation. However, human activities have accelerated natural erosion rates causing on- and off-site problems with soil degradation and sediment accumulation on undesirable locations (reservoirs, rivers, etc.) (Zeleke, 2000; Morgan, 2005; Amsalu et al., 2007; Mekonnen \& Melesse, 2011). Reservoir sedimentation is the product of on-site soil erosion resulting either from point sources like mining and construction sites or non-point sources such as from agricultural areas and grazing lands. Gully and river bank erosion are also important sources of sediment (Wasson et al., 2002; Ritsema, 2003; Keesstra et al., 2009b; Hughes \& Prosser, 2012).

In Ethiopia, the rates of soil erosion are alarmingly high and sedimentation in reservoirs, lakes, and rivers is a serious problem (Haregeweyn et al., 2006; Tamene et al., 2006a). Many reservoirs which have been established for hydroelectric power, urban water supply and irrigation accumulate large amounts of sediment, resulting in shortage of water supply for these functions, decline in reservoirs water storage capacity and high costs to remove sediment from reservoirs. Some of the dams in the Amhara region of Ethiopia, like the dams of Adrako, Borkena and Dana (Amare, 2005; Kebede, 2012) 
have completely silted up before their design expectation period. Other dams in this region that have been constructed over the last decades are threatened by accelerated sedimentation.

Until recently, most studies and development activities that aim at reducing the sediment load in the reservoirs were focused on on-site physical soil and water conservation (SWC) measures on agricultural areas in the catchment. Off-site physical sediment trapping measures inside gullies and drainage channels are largely disregarded. Moreover, SWC measures are not designed to eliminate sediment loss and transport to a safe level. For instance, in the northern part of Ethiopia, SWC measures such as stone bunds and ex-closures trapped about $74 \%$ of the total soil eroded (Nyssen et al., 2008). A structural measure, Fanya juu, trapped about $64 \%$ of the eroded soil at Debre Mewi watershed, northwest Ethiopia (Fisseha et al., 2011). Although on-site soil conservation measures result in reduced catchment sediment yields, sediment trapped by dams at the outlets of subcatchments as an off-site measure represent the dominant cause of reduced catchment sediment yields (Walling, 2006).

The STE of many off-site sediment trapping measures is well known. For instance; Markle (2009) demonstrated the efficacy of a sediment pond in a Californian almond orchard, which trapped 80$84 \%$ of the sediment. According to Verstraeten and Poesen (2001b), a typical pond of $1000 \mathrm{~m}^{3}$ in Belgium, showed a short term STE of $58-100 \%$ and a long term (33 yrs.) STE of $68 \%$. In Belgium, Verstraeten and Poesen (2002) tested the STE of 13 different sized ponds $\left(50 \mathrm{~m}^{3}-5 \mathrm{mill}^{\mathrm{m}} \mathrm{m}^{3}\right.$ ), which reveals a STE of $10-72 \%$. Wang et al. (2011) found that $>100000$ check dams store 21 billion $\mathrm{m}^{3}$ of sediment in the Loess Plateau of China in 50 years after construction. In Malaysia, Abedini et al. (2012) evaluated the STE of 3 check dams and their effectiveness in maintaining downstream reservoir storage capacity, which collectively trapped $6162 \mathrm{~m}^{3}$ of sediment. Sougnez et al. (2011) estimated the sediment volume trapped by 20 check dams in southern Spain as ranging from 4-920 $\mathrm{m}^{3}$. There are structures like sediment storage dams that could potentially serve as off-site sediment trapping in Ethiopia but have not been studied for their STE.

One possible way to trap sediment in the sediment cascade is using sediment storage dams (SSDs) (MERET, 2008). SSDs are physical structures or barriers built of stone or gabion at the outlets of catchments with the objective to trap sediment. SSDs have similar functions as check dams, i.e. to trap sediment except that they are mostly constructed at the outlets of larger catchments than check dam. These dams have been implemented by the Ethiopian government in the Amhara region over the last decade (MERET, 2008).

Hence, to assess the functioning and effectiveness of this type of measure this study aims to (II) quantify the amount of sediment trapped by SSDs constructed at the outlets of small sub-catchments in northwest Ethiopia and determine the sub-catchments sediment yield from the trapped sediment mass, (II) estimate the sediment trapping efficacy (STE) of SSDs, and (III) assess the costs required to construct the SSDs and its applicability for small scale farmers, in northwest Ethiopia. 


\subsection{Materials and methods}

\section{Study area description}

The study was conducted in Amhara Regional State, northwest Ethiopia. Eight SSDs constructed at the outlets of the small sub-catchments Shehena Borkena, Enchet Kab, Worka Wotu, Woybila, Segno Gebeya, Tigrie Mender, Dodota and Wuha Chale were studied (Figure 5.1). The size of the subcatchments ranged from 34.6-104.5 ha. Table 5.1 summarizes the location, average annual rainfall, soil type (WBISPP, 2002), average slope and elevation characteristics of each study site. Farmland is the dominant land use type in each sub-catchment amounting to about $80 \%$ while the remaining $20 \%$ is used as grazing land, eucalyptus plantation and/or bush land. The slopes in the subcatchments ranged from $0.4-31 \%$ with dominant average slopes of $11.6-24 \%$.

Table 5.1 Location, soil type, rainfall, slope and elevation characteristics of the studied sub-catchments

\begin{tabular}{|c|c|c|c|c|c|c|}
\hline Study sites & $\begin{array}{c}X \\
\text { coordinate } \\
(\mathrm{m})\end{array}$ & $\begin{array}{c}Y \\
\text { coordinate } \\
\text { (m) }\end{array}$ & Soil type & $\begin{array}{l}\text { Average } \\
\text { slope (\%) }\end{array}$ & $\begin{array}{l}\text { Av. Annual } \\
\text { rainfall (mm) }\end{array}$ & $\begin{array}{l}\text { Elevation range } \\
\text { (masl) }\end{array}$ \\
\hline Segno Gebeya & 410030 & 1204435 & Nitosols & 12.7 & 1200 & $2653-2754$ \\
\hline Woybila & 410018 & 1206409 & Nitosols & 16.4 & 1200 & $2675-2846$ \\
\hline Shehena Borkena & 584808 & 1209121 & Cambisol & 24.0 & 850 & $1508-1872$ \\
\hline Tigrie Mender & 533579 & 1330784 & Cambisol & 23.9 & 870 & $2960-3094$ \\
\hline Worka Wotu & 531127 & 1329944 & Cambisol & 11.7 & 870 & $2822-2895$ \\
\hline Dodota & 607310 & 1238353 & Cambisol & 11.6 & 800 & $1621-1762$ \\
\hline Enchet Kab & 402452 & 1449577 & Leptosol & 11.9 & 1200 & $3088-3171$ \\
\hline Wuha Chale & 591772 & 1259992 & Regosol & 23.7 & 900 & $1989-2174$ \\
\hline
\end{tabular}

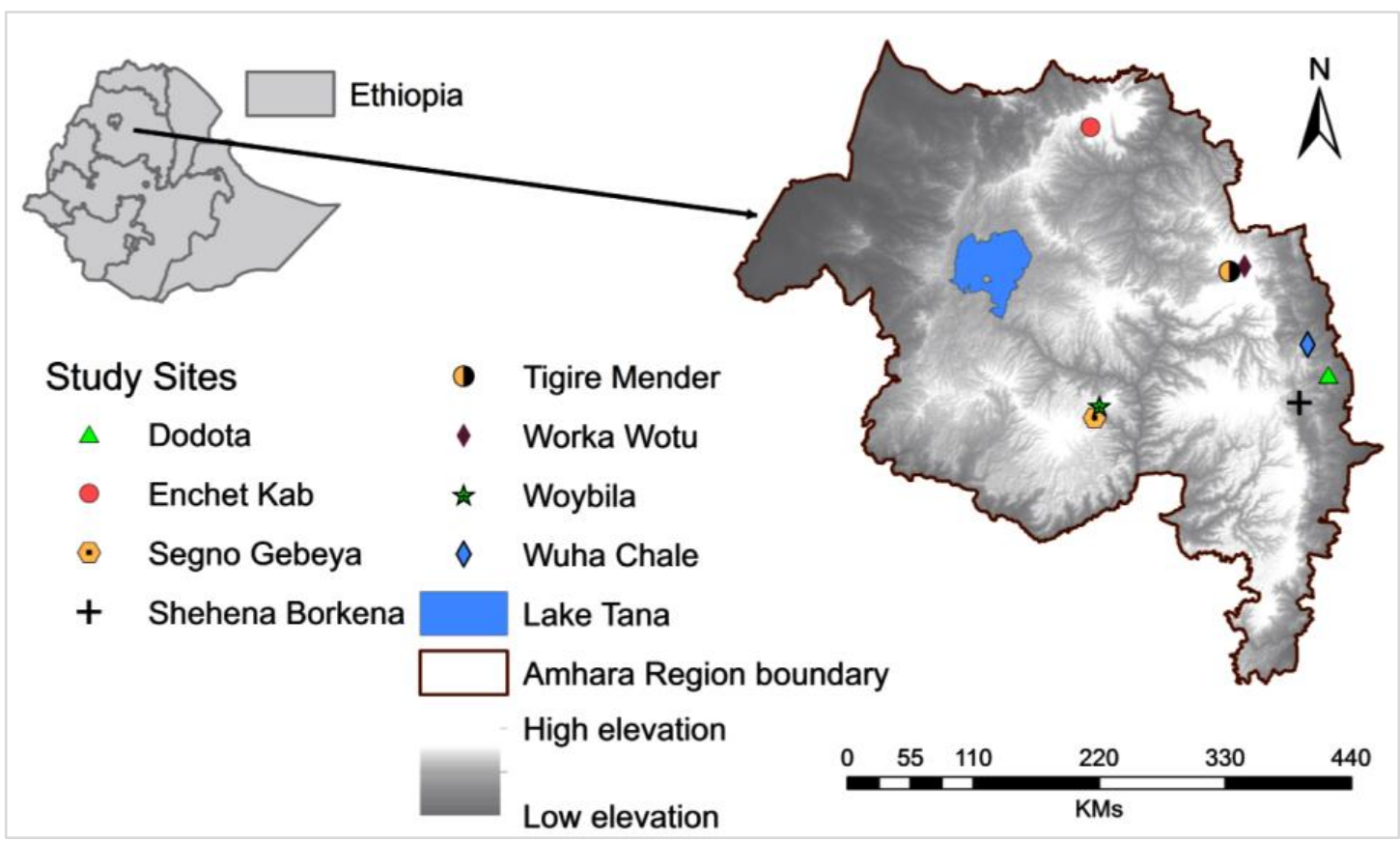

Figure 5.1 Location of the study sites 


\section{Materials and datasets}

Land use / land cover was determined using satellite imagery (SPOT; $5 \mathrm{~m}$ resolution). A topographic map 1:50,000 scale (EMA, 1987) was used to delineate the boundary of each sub-catchment. A Digital Elevation Model (ASTER DEM $30 \mathrm{~m}$; 2009) was used to derive the elevation and slope characteristics of each sub-catchment. Sub-catchments coordinates were taken in the field using a GPS device (Garmin GPS 60) and measurement tape was used to measure channel dimensions in each of the sub-catchments.

\section{Methods}

In order to quantify the amount of sediment trapped by sediment storage dams (SSDs), to determine the sediment trapping efficacy of the SSDs and to calculate sub-catchment sediment yield from the deposited sediment behind the dams the following methods were applied.

\section{Measuring trapped sediment in sediment storage dams}

To find multi-year data, SSDs with different ages (2-8 years old) in sub-catchments with different soil types, rainfall amounts and elevations were selected for this study. The amount of sediment trapped and stored behind each SSD was measured based on the geometric nature of the drainage channels, SSD dimensions and the surface area of the sediment using GPS and measuring tape. Some of the structures have trapezoidal shapes and others have rectangular shapes (see examples in Figure 5.2).

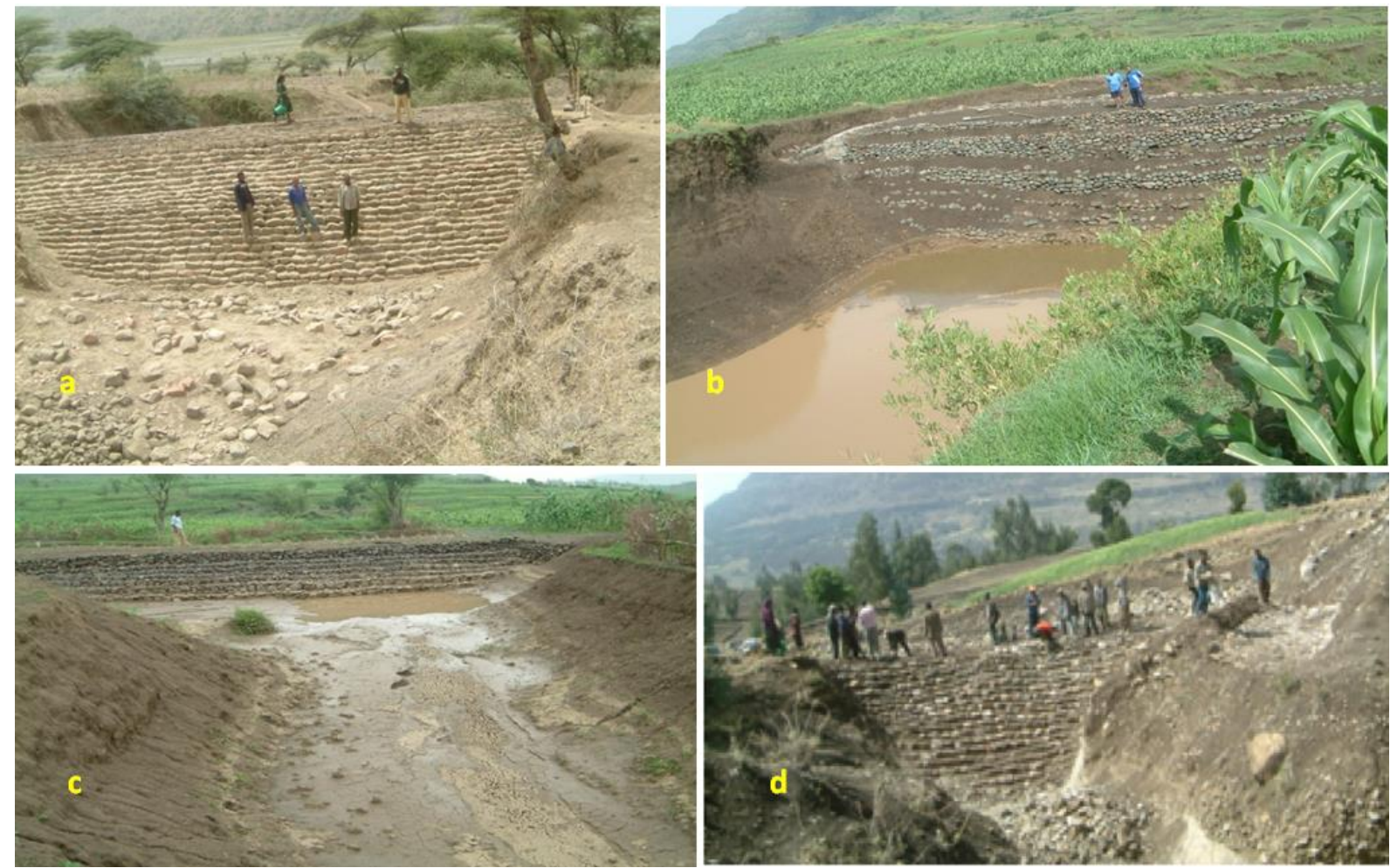

Figure 5.2 Examples of SSDs constructed in the Amhara region, Ethiopia (a) Delanta, (b) Kobo, (c) Bati and (d) Kutaber (Photos by Mulatie Mekonnen)

To calculate the volume $\left(\mathrm{V} ; \mathrm{m}^{3}\right)$ of the sediment accumulated behind the trapezoidal shaped dams, the cross-sectional area $\left(A ; m^{2}\right)$ of the sedimentation times the length $(L ; m)$ from the SSD to the end 
of sedimentation upstream was calculated (Eq. 5.1). The cross-sectional area (A) of the trapped sediment is the average of the top and bottom widths ( $b 2$ and $b 1 ; m)$ of the sediment times its height ( $h ; m$ ) measured from the base of the dam to the sediment surface (Eq. 5.2). For rectangular shape dams length times width times depth of the trapped sediment was used.

$V=A * L$

$A=\frac{1}{2}(b 1+b 2) * h$

\section{Estimating the sediment trapping efficacy}

A proportion of the sediment entering into the SSDs, particularly the finest sediment fraction, is not trapped but passes the dam as suspended sediment. Therefore, the SSDs sediment trapping efficacy (STE) should be estimated to be able to include the un-trapped sediment into the overall sediment budget. STE is also an important indicator of the functioning of the dams in retaining and conserving sediments (Morgan, 2005; Sougnez et al., 2011). Two representative SSDs, one built from gabion to represent gabion SSDs and one built from stone to represent stone SSDs, which are not full of sediment yet, were evaluated for their STE. For that purpose, a total of 82 suspended sediment samples were collected from 21 rainfall events during the rainy season in 2013, 40 samples (20 inflows and 20 outflows) for the gabion SSD and 42 samples (21 inflows and 21 outflows) for the stone SSD. STE was calculated based on the inflow and outflow suspended sediment samples (Coyne et al., 1995; Verstraeten \& Poesen, 2000) (Eq. 5.3).

$$
\text { STE }=\frac{\left(S_{\text {inflow }}-S_{\text {outflow }}\right)}{S_{\text {inflow }}}=1-\frac{S_{\text {outflow }}}{S_{\text {inflow }}} * 100
$$

Where:STE is sediment trapping efficacy (\%), $S_{\text {inflow }}$ is suspended sediment flowing into the SSD (g $\mathrm{I}^{-1}$ ) and $S_{\text {out flow }}$ is suspended sediment flowing out of the SSD $\left(\mathrm{g} \mathrm{I}^{-1}\right)$

\section{Sediment yield measurement}

Sediment yield (SY) is the total sediment outflow from a catchment, to be measured at a point of reference and in a specified period of time either in absolute terms (e.g., $\mathrm{t}^{-1}$ ) or in area specific terms (e.g., $\mathrm{t} \mathrm{ha}^{-1} \mathrm{y}^{-1}$ ) (Vanoni, 1975; Verstraeten \& Poesen, 2001a). Catchment sediment yield can be estimated by measuring the retained sediment in dams, reservoirs, check dams and ponds constructed at the outlet of a catchment (White et al., 1997; Verstraeten \& Poesen, 2002; Tamene et al., 2006b; Haregeweyn et al., 2008; Bellin et al., 2011; Sougnez et al., 2011; Baade et al., 2012). In this study, SY generated from the sub-catchments was estimated by measuring the deposited or trapped sediment behind the SSDs built at the outlets of the sub-catchments and estimating the untrapped sediment using the STE. The average annual SY transported from the catchments into the SSDs was calculated adding the trapped and un-trapped sediment and dividing it by the number of years involved to trap the sediment. Area specific sediment yield (SSY) was also calculated by dividing catchment sediment yield by catchment area. 


\section{Deposited sediment density calculation}

To convert sediment volume, which was directly measured in the field to dry sediment mass and to calculate the catchments sediment yield in terms of mass, the density of the trapped sediment was estimated using the cylindrical core method (McKenzie et al., 2002). In the middle of the deposited sediment a $1.5 \mathrm{~m}$ deep pit was dugout vertically downward and sampling was done at three depths (upper, middle and lower) pushing the cylindrical core sampler $(5 \mathrm{~cm}$ diameter $* 7 \mathrm{~cm}$ long) into the side wall at the desired depth. The collected samples were oven dried at $105{ }^{\circ} \mathrm{C}$ in the laboratory and sediment density was calculated weighing the dried sediment and subtracting it from the wet sediment mass.

\subsection{Results}

\section{STE, trapped sediment and sediment yield}

The average sediment inflow, outflow and sediment trapped was $197.4 \mathrm{gl}^{-1}, 51.2 \mathrm{gl}^{-1}$ and $146.2 \mathrm{gl}^{-1}$ at Segno Gebeya (gabion SSD) and $164.6 \mathrm{~g} \mathrm{l}^{-1}, 53.7 \mathrm{~g} \mathrm{l}^{-1}$ and $110.9 \mathrm{~g} \mathrm{l}^{-1}$ at Shehena Borkena (stone SSD), respectively. Based on these inflow and outflow suspended sediment data, STEs were calculated to be $74 \%$ and $67 \%$ for the gabion and stone SSDs, respectively. These efficacy values were used as a proxy for the SSDs of the other sub-catchments to be able to calculate the un-trapped sediment. Table 5.2 shows the measured trapped and estimated un-trapped sediment of each SSD. The average volume of sediment trapped and accumulated behind the eight SSDs within 2-8 years was found to be $5500 \mathrm{~m}^{3}$, but with high variation between sites (st. dev. of $4665 \mathrm{~m}^{3}$ ) reflecting differences in catchment size and soil erosion factors.

Sediment bulk density values ranged from $1.33 \mathrm{~g} \mathrm{~cm}^{-3}$ in heavy clay sediment deposits to $1.53 \mathrm{~g} \mathrm{~cm}^{-3}$ in sandy loam dominated sediments. On average SSDs trapped about $1584 \mathrm{t}$ of sediment annually. Figure 5.3 illustrates part of the sediment trapped and deposited behind the SSDs. Table 5.3 shows calculated annual sediment yield (SY) and area specific sediment yield (SSY) for all sub-catchments. SY and SSY show large variation between sub-catchments, ranging from 297-5759 $t$ and $8.6-55 t$ ha $^{-1}$ $\mathrm{y}^{-1}$, respectively.

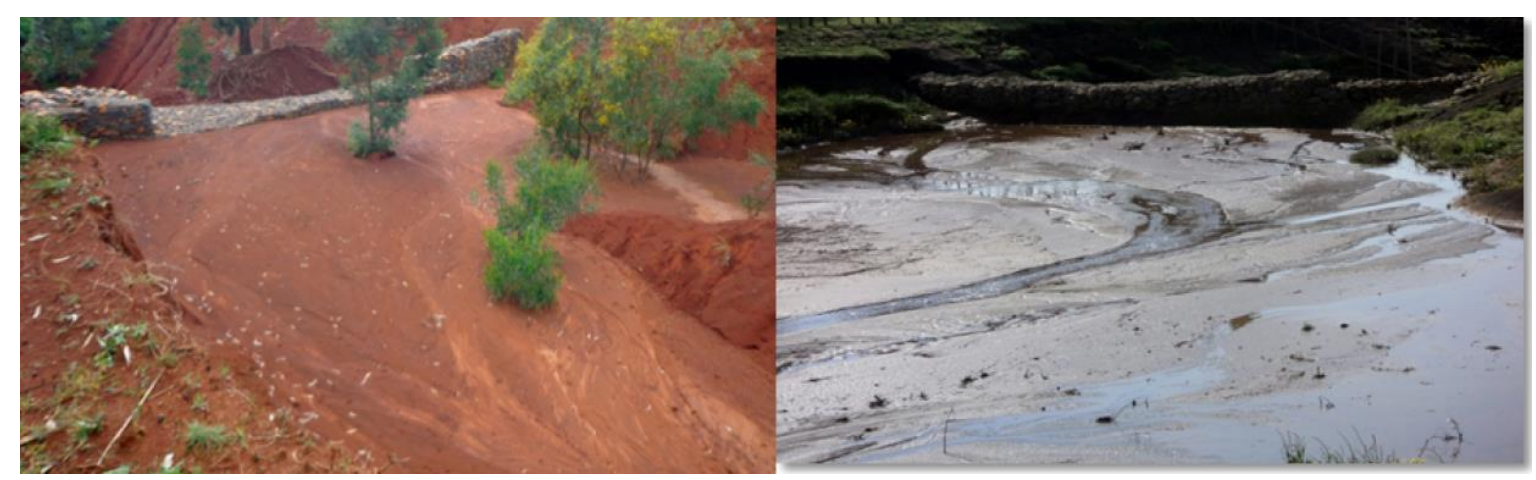

Figure 5.3 Example SSDs and trapped sediment at Segno Gebeya (left) and Enchet Kab (right) (Photo by Mulatie Mekonnen) 


\section{Cost of sediment storage dams}

The cost of building an SSD is an important factor affecting its implementation by small scale farmers and it's up-scaling to other users. The most important inputs such as stone, gabion and human labour were evaluated and their costs were estimated (Table 5.4). On average $€ 8.74$ and $€ 5.85$ are required to construct $1 \mathrm{~m}^{3}$ gabion and stone SSDs, respectively. This means that to trap $1 \mathrm{~m}^{3}$ sediment about $€ 2.0$ for a gabion and from $€ 0.4$ to $€ 1.7$ for a stone SSD was spent, which was calculated by dividing the dam costs by the volume of sediment trapped. The cost to trap $1 \mathrm{~m}^{3}$ sediment varies ( $€$ 0.4 to $€ 1.7$ ) although similar construction cost ( $€ 5.85$ ) was financed for $1 \mathrm{~m}^{3}$ of all stone SSDs. This is because of difference in the amount of trapped sediment behind the constructed dams due to difference in shape of the reservoir in which sediment is deposited. The larger the reservoir behind the dam, the higher the amount of sediment trapped and the lower the cost per $\mathrm{m}^{3}$ of sediment and vice-versa. In all studied SSDs labour costs were found to be higher than material costs.

Table 5.2 Soil bulk density, volume and mass of sediment trapped and un-trapped by SSDs.

\begin{tabular}{llrrrrr}
\hline Catchments & type & $\begin{array}{r}\text { trapped } \\
\text { sediment }\left(\mathrm{m}^{3}\right)\end{array}$ & $\begin{array}{r}\text { bulk density } \\
\left(\mathrm{g} \mathrm{cm}^{-3}\right)\end{array}$ & $\begin{array}{r}\text { trapped } \\
\text { sediment }(\mathrm{t})\end{array}$ & $\begin{array}{r}\text { trapped } \\
\text { sediment }\left(\mathrm{t} \mathrm{y}^{-1}\right)\end{array}$ & $\begin{array}{r}\text { Un-trapped } \\
\text { sediment }(\mathrm{t})\end{array}$ \\
\hline Segno Gebeya & Gabion & 3240 & 1.33 & 4309.2 & 2154.6 & 1120.4 \\
Woybila & Stone & 15920 & 1.36 & 21651.2 & 4330.2 & 7144.9 \\
Shehena Borkena & Stone & 6156 & 1.53 & 6418.7 & 1069.8 & 2118.2 \\
Tigrie Mender & Stone & 1321 & 1.42 & 1875.8 & 468.9 & 619.0 \\
Worka Wotu & Stone & 1516 & 1.18 & 1788.9 & 223.6 & 590.3 \\
Dodota & Stone & 1085 & 1.31 & 1431.4 & 357.9 & 472.4 \\
Enchet Kab & Stone & 7593 & 1.40 & 10630.2 & 2657.6 & 3508.0 \\
Wuha Chale & Stone & 7167 & 1.38 & 9890.5 & 1412.9 & 3263.9 \\
\multicolumn{1}{c}{ Average } & & 5500 & 1.36 & 7249 & 1584.4 & 2355 \\
\multicolumn{1}{c}{ St. dev } & & 4665 & 0.09 & 6400 & 1502.2 & 2132 \\
\hline
\end{tabular}

Table 5.3 Catchment area, SSDs age, sediment yield and area specific sediment yield of each catchment

\begin{tabular}{lccrr}
\hline Catchments & Area (ha) & SSDs age $(\mathrm{y})$ & SY $\left(\mathrm{t} \mathrm{y}^{-1}\right)$ & $\mathrm{SSY}^{-1} \mathrm{t} \mathrm{ha}^{-1} \mathrm{y}^{-}$ \\
\hline Segno Gebeya & 56.0 & & 2714.8 & 48.5 \\
Woybila & 104.5 & 2 & 5759.2 & 55.1 \\
Shehena Borkena & 66.9 & 5 & 1422.8 & 21.3 \\
Tigrie Mender & 41.8 & 4 & 623.7 & 14.9 \\
Worka Wotu & 34.6 & 8 & 297.4 & 8.6 \\
Dodota & 39.0 & 4 & 475.9 & 12.2 \\
Enchet Kab & 84.3 & 4 & 3534.5 & 41.9 \\
Wuha Chale & 71.8 & 7 & 1879.2 & 26.2 \\
\hline
\end{tabular}


Table 5.4 Type, size and costs of sediment storage dams

\begin{tabular}{lccccccc}
\hline $\begin{array}{l}\text { SSD } \\
\text { sites }\end{array}$ & $\begin{array}{c}\text { SSD } \\
\text { type }\end{array}$ & $\begin{array}{c}\text { SSD size } \\
\left(\mathrm{m}^{3}\right)\end{array}$ & $\begin{array}{c}\text { Stone } \\
\text { Cost }\end{array}$ & $\begin{array}{c}\text { Gabion } \\
\text { cost }\end{array}$ & $\begin{array}{c}\text { Labour } \\
\text { cost }\end{array}$ & $\begin{array}{c}\text { Total } \\
\text { cost }\end{array}$ & $\begin{array}{c}\text { Cost per } \mathrm{m}^{3} \\
\text { of sediment }\end{array}$ \\
\hline Segno Gebeya & Gabion & 756 & 2063.9 & 2180 & 2358.7 & 6602.7 & 2.03 \\
Woybila & Stone & 972 & 2653.6 & - & 3032.6 & 5686.2 & 0.36 \\
Shehena & Stone & 483 & 1318.6 & - & 1507.0 & 2825.6 & 0.46 \\
Borkena & & & & & & & 1.44 \\
Tigrie Mender & Stone & 325 & 887.3 & - & 1014.0 & 1901.3 & 1.68 \\
Worka Wotu & Stone & 437 & 1193.0 & - & 1363.4 & 2556.4 & 1.64 \\
Dodota & Stone & 306 & 835.4 & - & 954.7 & 1790.1 & 0.39 \\
Enchet Kab & Stone & 529 & 1444.2 & - & 1650.5 & 3094.7 & 0.51 \\
Wuha Chale & Stone & 617 & 1684.4 & - & 1925.0 & 3609.4 & 0.4 \\
\hline
\end{tabular}

Stone cost $-2.73 € \mathrm{~m}^{-3}$, Gabion cost $-16.77 €$ gabion $^{-1}$, Labour cost $-1.56 € 0.5 \mathrm{~m}^{-3}$ person ${ }^{-1}$, Average costs are considered and all costs are in $€(1$ Ethiopian birr $=0.039 €)$

\subsection{Discussion}

Sediment trapped by sediment storage dams and catchment sediment yield

Rising rates of on-site soil erosion and off-site sedimentation in reservoirs and lakes emphasises the need to trap sediment along the sediment transfer pathways. Dam construction of both large and small sizes to trap sediment can reduce downstream sedimentation, flooding and other environmental problems. The world's registered 45,000 large dams can trap 4-5 billion $\mathrm{t}^{-1}$ of sediment (Vorosmarty et al., 2003). In China $>100000$ smaller check dams trapped 21 billion $\mathrm{m}^{3}$ of sediment (Wang et al., 2011). Sougnez et al. (2011) estimated the sediment volume trapped by 20 check dams in southern Spain as ranging from 4-920 $\mathrm{m}^{3}$. In this study, sediment storage dams (SSDs) built at the outlets of eight small sub-catchments in the Amhara region in Ethiopia trapped a total of about $58 * 10^{3} \mathrm{t}\left(44 * 10^{3} \mathrm{~m}^{3}\right)$ sediment. On average these SSDs trapped about $1584 \mathrm{t}$ of sediment annually.

In addition to reducing downstream reservoirs sedimentation, SSDs contributed in conserving soil within the larger catchment and re-filling and stabilizing gullies. An SSD constructed at Woybila catchment within a gully, which is serving as a temporary drainage channel during the rainy seasons, trapped $\sim 22 * 10^{3} \mathrm{t}$ of sediment and refilled an $8 \mathrm{~m}$ deep and $20 \mathrm{~m}$ wide gully in 5 years reducing the channel slope gradient by $12 \%$ on average, which can slow down the speed of runoff and give time for infiltration and sediment deposition.

Sediment trapped and stored behind sediment trapping measures can be used to estimate sediment yield produced by upper catchments (White et al., 1997; Verstraeten \& Poesen, 2002; Bellin et al., 2011; Sougnez et al., 2011; Baade et al., 2012). In this study, the annual sediment yield of the investigated sub-catchments ranged from 8.6-55 $\mathrm{t} \mathrm{ha}^{-1}$, which is in line with other findings in Ethiopia. For example, in northwest Ethiopia, average annual sediment yield of $24.6 \mathrm{t} \mathrm{ha}^{-1}$ at Anjeni catchment (Setegn et al., 2010) and $13.6 \mathrm{t} \mathrm{ha}^{-1}$ at Angereb catchment (Amare, 2005) were reported. In the northern part of Ethiopia, the annual sediment yield of 10 catchments was estimated at $4-18 \mathrm{t} \mathrm{ha} \mathrm{a}^{-1}$ 
(Haregeweyn et al., 2008) and 3.4-49 $\mathrm{t} \mathrm{ha}^{-1}$ (Tamene et al., 2006a) for another 11 catchments in the same region.

Catchment size is an important controlling factor for catchment sediment yield (Morgan, 2005). For example, a direct relationship between area specific sediment yield and catchment area has been reported in different studies (de Vente et al., 2006; Haregeweyn et al., 2008) for small size catchments and a similar result was obtained in this study with $R^{2}=0.66$ (Figure 5.4). This is due to limited deposition of the transported sediment within such small sub-catchments.

According to Wasson et al. (2002), about $80 \%$ of the sediment in the Argyle reservoir, Australia has come from gully and channel erosions, and sediment yield in three small size gullied catchments (29, 52 and $510 \mathrm{ha}$ ) is at least one order of magnitude higher than that of un-gullied catchments (Armstrong \& Mackenzie, 2002). In this study in the Segno Gebeya, Wuha Chale and Woybila subcatchments foot paths, gullies and traditional ditches, and in the Enchet Kab and Shenena Borkena sub-catchments channel bank and gully erosions have some contribution for the estimated sediment yield.

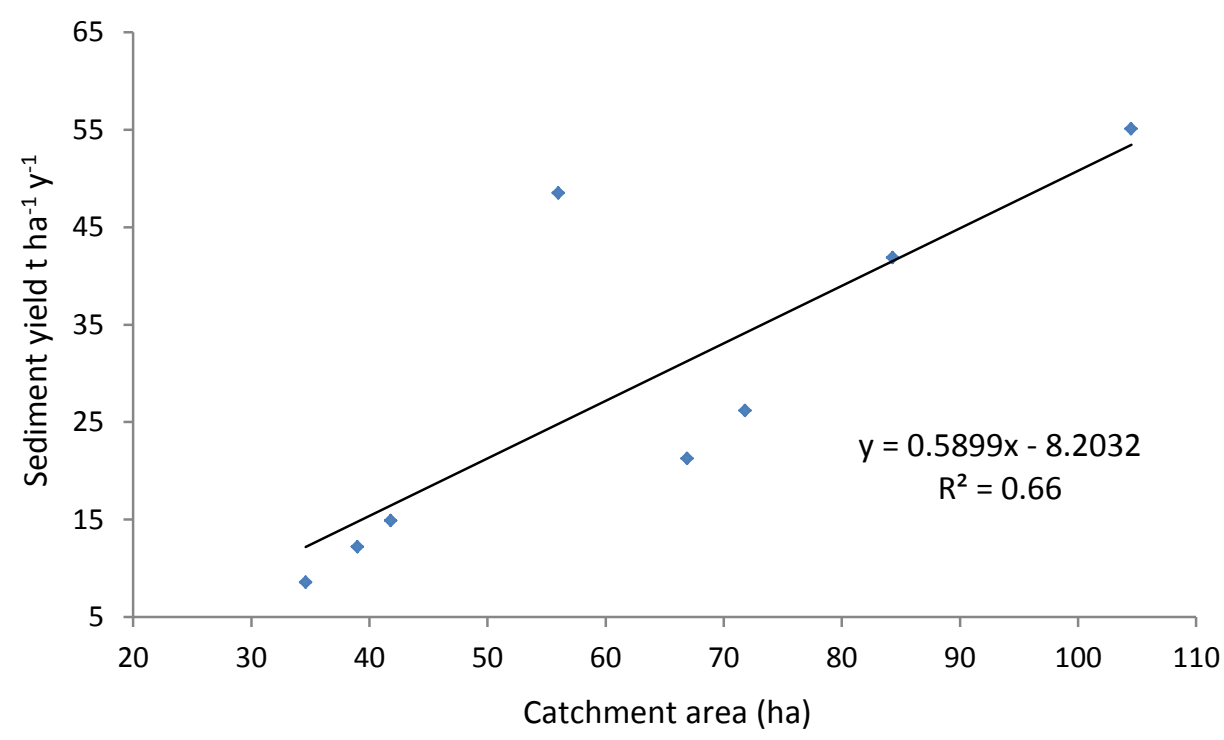

Figure 5.4 The relationship between annual sediment yield $\left(t h a^{-1}\right)$ and small size catchments

\section{Sediment trapping efficacy}

Sediment trapping efficacy is an important factor to evaluate the effectiveness of sediment trapping measures. Markle (2009) demonstrated the efficacy of a sediment pond in a Californian almond orchard, which trapped $80-84 \%$ of the sediment. According to (Verstraeten \& Poesen, 2001b), a typical pond of $1,000 \mathrm{~m}^{3}$ with a catchment area of 25 ha in Belgium showed a short-term STE of 58$100 \%$ and a long-term ( $33 \mathrm{yr}$ ) STE of $68 \%$. In northern Mississippi, the STE of small reservoirs was found to be 77\% (Dendy \& Cooper, 1984). In the northern part of Ethiopia Haregeweyn et al. (2006) estimated the STE of 10 reservoirs which ranged from $85-100 \%$ and Tamene et al. (2006a) found STEs ranging from $86-97 \%$ in 11 catchments. In this study the STE of gabion and stone SSDs were found to be $74 \%$ and $67 \%$, respectively. This indicates that SSDs can trap and conserve up to $3 / 4$ of the inflow 
sediment coming from the upstream catchments in the form of surface erosion or concentrated through gullies, channel banks or foot path erosion and can be used as potential off-site sediment trapping measures.

The deposited sediment behind sediment trapping dams is an important indicator of soil loss in its upstream catchment provided the efficacy of the dams as a sediment trap is known (Morgan, 2005). For instance, the deposited sediment behind check dams was used to estimate soil loss from its upstream catchments (Bellin et al., 2011; Sougnez et al., 2011; Romero-Diaz et al., 2012). In this study soil loss in the upstream catchments was estimated at 8.6-55 tha $\mathrm{h}^{-1} \mathrm{y}^{-1}$. The soil loss value found in this study is within the same range of the study results conducted in northwest Ethiopia (Zegeye et al., 2010; Mekonnen \& Melesse, 2011; Haile \& Fetene, 2012). The total soil eroded within the catchments and transported into the SSDs was estimated by adding the trapped and un-trapped sediment. This method of estimating soil loss provides better results than for instance plot-scale measurement and catchment-scale river discharge sampling methods. This is because it represents the combined effects of soil erosion factors (soil type, land use/cover, slope, rainfall variability, etc.) at larger natural conditions, against plot-scale. Compared with data from suspended sediment concentrations, the data from sediment trapping dam survey incorporates materials transported as bed loads as well as suspended sediments which make the method more accurate.

Gullies and drainage channels are effective links to transfer runoff and sediment from upper parts of a catchment to their outlets (Poesen et al., 2003) and serve as important sediment source and transfer pathways. The main objective of constructing SSDs within drainage channels is therefore to disconnect such paths and trap the sediment (MERET, 2008). Disconnecting sediment transfer pathways through efficient sediment trapping measures could help to increase sediment deposition and reduce downstream sediment loads (Keesstra et al., 2009a; Baartman et al., 2013). In this study, SSDs were found as important structural measures in disconnecting the sediment transfer pathways and reducing the transport of sediment from upstream catchments to downstream water bodies (rivers, reservoirs or lakes).

Although SSDs played an important role in trapping sediments and reducing downstream sedimentation problems, they provide short term benefits (For example five out of the eight SSDs investigated have completely silted up in 4-8 years). After the dams are fully filled with sediment, the sediment transportation continues further downstream. To solve this problem sustainably, options are to (i) construct a series of dams within the drainage channel, which can increase the lifespan of each dam, and at the same time (ii) implementing on-site soil and water conservation measures (e.g. terraces and grass strips on farmlands, area closure on degraded lands, check dams inside gullies, etc.) to reduce erosion and trap the sediment within the sub-catchment before it reaches the SSDs. According to Mekonnen et al. (2014b) the integration of on-site and off-site sediment trapping measures at the catchment scale, is believed to be the most effective in helping to increase the STE of the measures and thereby reducing sediment loads at the outlet of the catchment.

According to Nyssen et al. (2007a) the increased erosive capacity and power of the low sedimentladen runoff can lead to scour and enhanced soil erosion. In this study, below the SSDs there were 
bottom and side scouring in some of the drainage channels, which might be due to the downstream effect of the clear water as a result of sediment accumulation behind the dams. Implementing vegetative measures, for example, planting grass and tree species and covering the bare land inside the temporary drainage channels where the SSDs have been built will be an option to minimize the problem.

\section{Cost required of construction of sediment storage dams}

In addition to sediment trapping efficacy (STE), the costs required to construct the sediment storage dam is an important factor affecting implementation of the sediment trapping measure at wider spatial scale and its adoption by farmers. Three most important inputs for SSD construction (human labour, gabion and stone) were assessed. Both stone and gabion SSDs are not affordable by the small scale farmers in northwest Ethiopia unless other alternatives are designed. For example: (i) a mass mobilization approach, which the Ethiopian government currently uses for soil and water conservation works. This forms a means to implement SSDs with free community participation to minimize at least the labour costs, which were found to be the largest part of the total construction costs; (ii) project support to cover at least the gabion (material) costs; and (iii) implementing SSDs where there is excess stone to reduce stone costs. These approaches could help to minimize the costs and up-scale the measures to wider spatial scales.

\subsection{Conclusions}

Sediment storage dams (SSDs), both gabion and stone, were found to be important off-site structural sediment trapping measures trapping sediment at the outlets of small sized catchments. The eight SSDs investigated, built from gabion and stone trapped a total of $\sim 44 * 10^{3} \mathrm{~m}^{3}$ or $\sim 58 * 10^{3} \mathrm{t}$ of sediment within 2-8 years with sediment trapping efficacies of $74 \%$ and $67 \%$, respectively. In addition to evaluating the effectiveness of the dams, STE was used to estimate suspended sediment losses, and subsequently total (sub) catchment sediment yield. SSDs also reduce channel slope gradients and disconnect sediment transfer pathways inside drainage channels in addition to re-filling gullies. The lifespan of the investigated SSDs was relatively short, i.e. to be more effective and use the SSDs sustainably they should be integrated with on-site soil conservation measures. Also, due to high costs, SSDs are not affordable for small scale farmers, alternatives to minimize the cost like mass mobilization, project support and implementing the dams in areas of excess construction materials should be considered to be able to upscale these measures. 


\section{Chapter 6}

\section{Reducing sediment connectivity through man-made and natural sediment sinks in the Minizr catchment, NW Ethiopia}

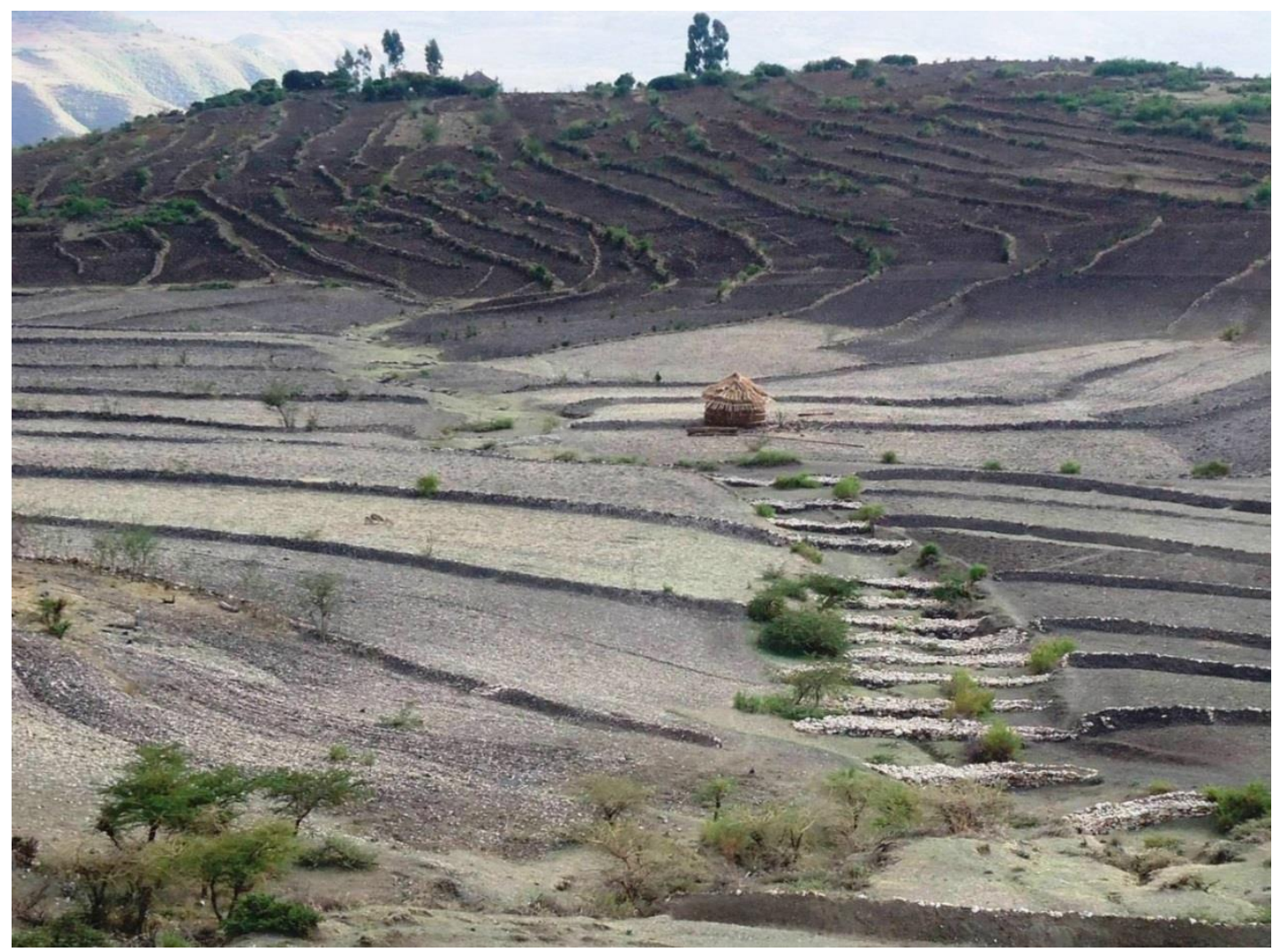

This paper is accepted as:

M. Mekonnen, S.D. Keesstra, J.E.M Baartman, L. Stroosnijder, J. Maroulis. 2016. Reducing sediment connectivity through man-made and natural sediment sinks in the Minizr catchment, northwest Ethiopia.

Land Degradation and Development.

Published online in 2016 in Wiley Online Library (Wileyonlinelibrary.com) DOI:10.1002/Idr.2629 


\section{Reducing sediment connectivity through man-made and natural sediment sinks in the Minizr catchment, NW Ethiopia}

Abstract

Man-made and natural sediment sinks provide a practical means for reducing downstream reservoir sedimentation by decreasing soil erosion and enhancing the rate of sedimentation within a catchment. The Minizr catchment $\left(20 \mathrm{~km}^{2}\right)$ in the northwest Ethiopian highlands contains numerous man-made soil and water conservation (SWC) structures (such as soil bunds (Erken), fanya juu ridge (Cab) and micro-trenches) and natural sediment sinks (wetlands, floodplains and grassed waterways). These sediment sinks reduce downstream sedimentation into the Koga reservoir, located at the catchment outlet, however, a large quantity of sediment is still reaching the reservoir. This study evaluates the function and effectiveness of both man-made SWC structures and natural sediment sinks in reducing sediment export from the Minizr catchment. SWC structures and natural sediment sinks were digitized using Google Earth Imagery. Sediment pins and vertical sampling through the deposit were used to quantify the amount of deposited sediment. In addition, inflow and outflow of suspended sediment data were used to calculate the sediment-trapping efficacies (STE) of man-made SWC structures (soil bunds and fanya juu ridges) and natural sediment sinks. Results reveal that $144 \mathrm{~km}$ soil bunds and fanya juu ridges trapped 7,920 Mg y $\mathrm{y}^{-1}\left(55 \mathrm{~kg} \mathrm{~m}^{-1} \mathrm{y}^{-1}\right)$ and micro-trenches trapped $13.26 \mathrm{Mg} \mathrm{y}^{-1}$ (each micro-trench on average trapped $\left.23 \mathrm{~kg} \mathrm{y}^{-1}\right)$. The 17 ha floodplain located in the centre of the catchment trapped $9,970 \mathrm{Mg} \mathrm{y}^{-1}\left(59 \mathrm{~kg} \mathrm{~m}^{-2} \mathrm{y}^{-1}\right)$, while a wetland with a surface area of $24 \mathrm{ha}$, located near the outlet of the catchment, trapped 8,715 Mg $y^{-1}\left(36 \mathrm{~kg} \mathrm{~m}^{-2} \mathrm{y}^{-1}\right)$. The STEs of soil bunds and fanya juu ridges, wetlands and floodplains were 54\%, 85\% and 77\%, respectively. Substantial differences were observed between the STE of grassed and un-grassed waterways at $75 \%$ and $21 \%$, respectively. Existing man-made and natural sediment sinks played an important role in trapping sediment, with $38 \%\left(26,600 \mathrm{Mg}^{-1}\right)$ of transported sediment being trapped, while 62\% $\left(43,000 \mathrm{Mg} \mathrm{y}^{-1}\right)$ is exported from the catchment and thus enters the Koga reservoir. Therefore, additional catchment treatment measures are required as an integrated catchment scale sediment trapping (ST) approach to help reduce sediment loads entering Koga reservoir. Moreover, to maximize the effectiveness of ST measures, avoid structural failure and ensure their sustainability, regular maintenance is needed.

\subsection{Introduction}

Soil erosion by runoff water is a global land degradation problem (Dai et al., 2015; Seutloali \& Beckedahl, 2015; Stanchi et al., 2015; Novara et al., 2016; Ochoa et al., 2016). However, it is more severe in developing countries like Ethiopia (Hurni, 2000; Nyssen et al., 2004) and results in significant economic losses (Erkossa et al., 2015). Currently, water erosion is the most serious land degradation threat to the upper part of the Blue Nile basin within the north-western highlands of Ethiopia (Adimassu et al., 2014; Mekonnen et al., 2015a; Ayele et al., 2016). The main causes include erosive high intensity tropical rains, rugged steep topography, extensive deforestation for fuel wood, expansion of cultivation into unsuitable steeply sloping and erosion prone areas, high population pressure and the lack of integrated catchment management (Zeleke, 2000; Bewket, 2002; Nyssen et al., 2004; Amsalu et al., 2007; Mekonnen \& Melesse, 2011; Mekonnen et al., 2014b). 
Therefore, a holistic approach is needed to tackle soil erosion in the region (Mekonnen et al., 2014b; Lanckriet et al., 2015; Nyssen et al., 2015; Tesfaye et al., 2015). Soil and water conservation (SWC) structures provide a practical means for reducing soil erosion, enhancing the rate of sedimentation and decreasing local slope gradient (Gebremichael et al., 2005; Mekonnen et al., 2015b). Various soil and water conservation measures have been implemented at large spatial scales by the Ethiopian government and international and national non-governmental organizations. For instance, 2.1 million ha of hillsides and farmlands were covered by SWC structures in the Amhara National Regional State from 2011 to 2013 (Engdayehu et al., 2015), and a further 1.2 million ha in 2014-2015 (BOA, 2015).

Effective sediment trapping (ST) measures can disconnect landscape units from each other, resulting in a decrease in runoff velocity and sediment transport and, subsequently, reduced downstream flooding with fewer sedimentation impacts (Mekonnen et al., 2014b). This is enhanced by placing barriers and buffers in the catchment, which ultimately reduces sediment connectivity (Fryirs, 2012). According to (Baartman et al., 2013), man-made structures such as terraces reduce sediment delivery to the catchment outlet. Research has shown that leaving mulch on the soil surface within the catchment can also reduce the amount of sediment being detached (Cerda et al., 2015; Keesstra et al., 2016; Prosdocimi et al., 2016).

The Minizr catchment is an important source of water for the Koga reservoir in the northwest highlands of Ethiopia (Figure 6.1). To trap sediment within the catchment and reduce sediment loads reaching the reservoir, considerable effort was made to implement soil bund (Erken) and fanya juu ridge ( $\mathrm{Cab}$ ) and also micro-trench structures across large sections of the catchment. Over $144 \mathrm{~km}$ of soil/stone bunds and fanya juu ridges, and $>576$ micro-trenches were constructed within the catchment. In addition, existing natural sediment sinks such as wetlands and floodplains occur over large areas of the catchment, and are supplementing man-made structures in trapping sediment within the catchment (Figure 6.1).

Nevertheless, considerable soil is being eroded from the Minizr catchment and transported into the Koga reservoir: annually 43,000 Mg of suspended sediment enters the Koga reservoir (Mekonnen et al., 2016c). In order to reduce the sediment load through improving the sediment trapping efficacy (STE) of the SWC structures, it is important to assess the functioning and effectiveness of existing SWC structures. According to (Yeshaneh et al., 2014), there is a lack of in-depth studies quantifying the volume of sediment being deposited within SWC structures. Previous research demonstrates that terraces play a key role in trapping sediment and disconnecting sediment transfer pathways in a catchment, but very few have been measured (Marchamalo et al., 2016).

Consequently, the objectives of this study in the Minizr catchment, northwest Ethiopia were to: (i) evaluate the functioning and effectiveness of both man-made structures (soil bund, fanya juu and micro-trenches) and natural sediment sinks (floodplain, wetland and waterways) and, (ii) quantify the amount of sediment trapped and stored in these man-made and natural sediment sinks. 


\subsection{Materials and methods}

\section{Study area}

The study was conducted in the Minizr catchment in the North-western highlands of Ethiopia (UTM 1255891 - 1249499 N; 303559 - 310272 E; Adindan_UTM_Zone_37N, Figure 6.1) which is a source of water for the Koga reservoir. It covers an area of $20 \mathrm{~km}^{2}$ with an elevation range of $2035 \mathrm{~m}$ at the outlet to 2283 m.a.s.I at its highest point on the watershed divide. Slopes in the catchment range from $0-51 \%$ (average of $8 \%$ ), while $>80 \%$ of the catchment has slopes between $0-8 \%$.

Average rainfall (2013-2015) was $1215 \mathrm{~mm} \mathrm{y}^{-1}$, which falls mainly between June to September, and is preceded and followed by one month of sporadic, low intensity rain. Average minimum and maximum temperatures are $11^{\circ} \mathrm{C}$ and $26^{\circ} \mathrm{C}$, respectively. The dominant soil types are Nitosols (62\%), Eutric Vertisols (30\%), Lithic Leptosols (6\%) and Chromic Cambisols (2\%) (MNREP, 1995). Land use within the catchment area includes $71 \%$ cropping land, $18 \%$ grazing land, while plantation, bush land and settlement areas account for the remaining $11 \%$.

Figure 6.1 shows the $144 \mathrm{~km}$ soil bund and fanya juu ridges implemented in Minizr catchment, a 24 ha wetland located near the outlet of the catchment and a small floodplain area of 17 ha located at the center of the catchment, which help to trap sediment and reduce sedimentation of Koga reservoir. In the wetland area, Chromic Cambisols dominate. They are developed from alluvial deposits. The soil is very deep, poorly drained with a dark gray to grayish brown, silty clay loam texture, while the floodplain soil is a Eutric Vertisol which is a very deep, poor to very poorly drained, cracking heavy clay textured soil. The floodplain is $696 \mathrm{~m}$ long and $243 \mathrm{~m}$ wide and is covered with grass, which serves as a grazing area during the dry season.

\section{Mapping}

All SWC structures, land use/cover, wetland and floodplain areas were digitized and mapped from Google Earth Imagery using ArcGIS 10.2.1. A Digital Elevation Model (ASTER DEM 30 m; 2009) was used to delineate the boundary of the Minizr catchment and for evaluating its elevation and slope characteristics. A GPS (Garmin 60; 2 m accuracy) helped to collect coordinate points and accurately geo-reference the location of rain gauges, sediment sampling sites and the catchment outlet.

\section{Measuring trapped sediment in SWC structures}

Three types of SWC structures soil bund (Erken), fanya juu ridge (Cab) and micro-trenches have been widely implemented throughout the Minizr catchment (Figure 6.2). Soil bund and fanya juu ridges were built on farmers' fields, whereas micro-trenches were constructed on degraded grazing lands and integrated with area closures. Figure 6.3 shows the detailed dimensions of the soil bund and fanya juu ridge (MOARD, 2005). 


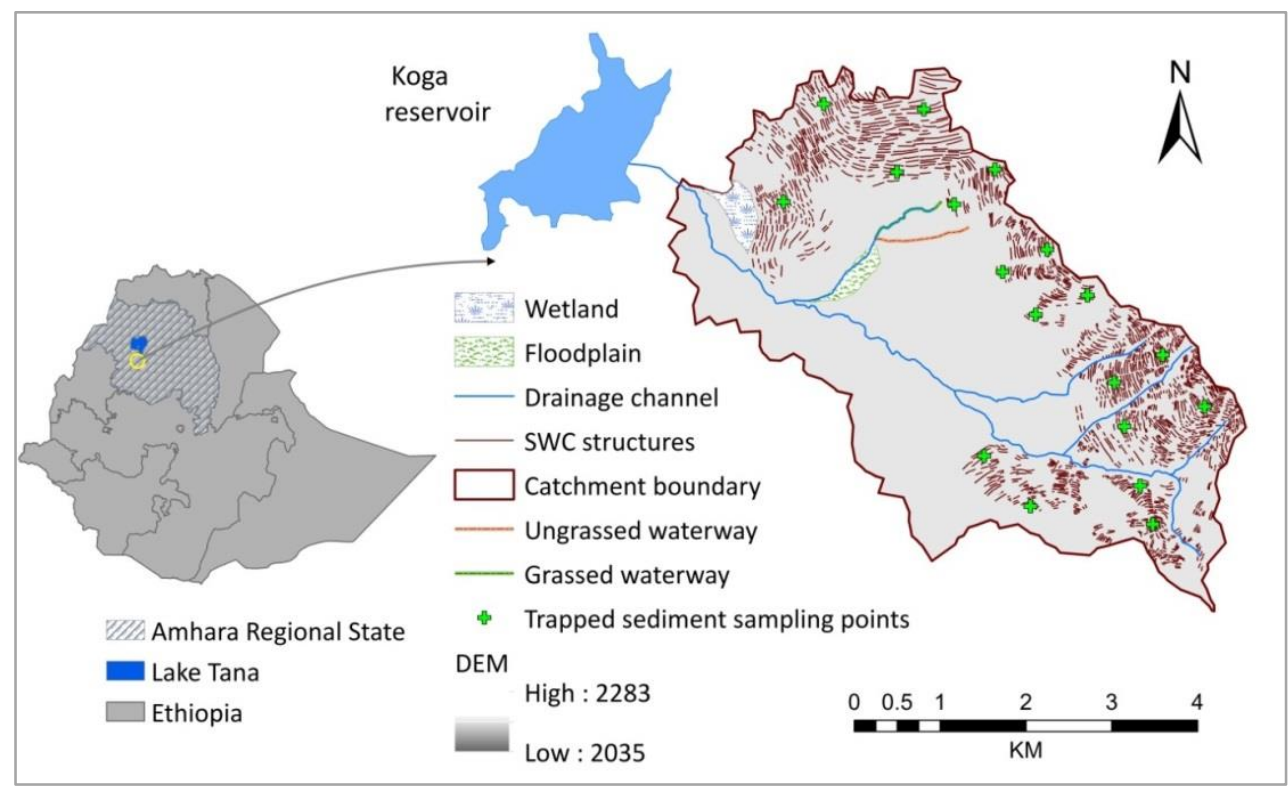

Figure 6.1 Location map of the Minizr catchment, in the NW Ethiopian highlands of the Upper Blue Nile basin showing the SWC structures implemented to trap sediment (soil bunds and fanya juu ridges), natural sediment sinks (floodplain, wetland and grassed waterway); and trapped sediment sampling sites.

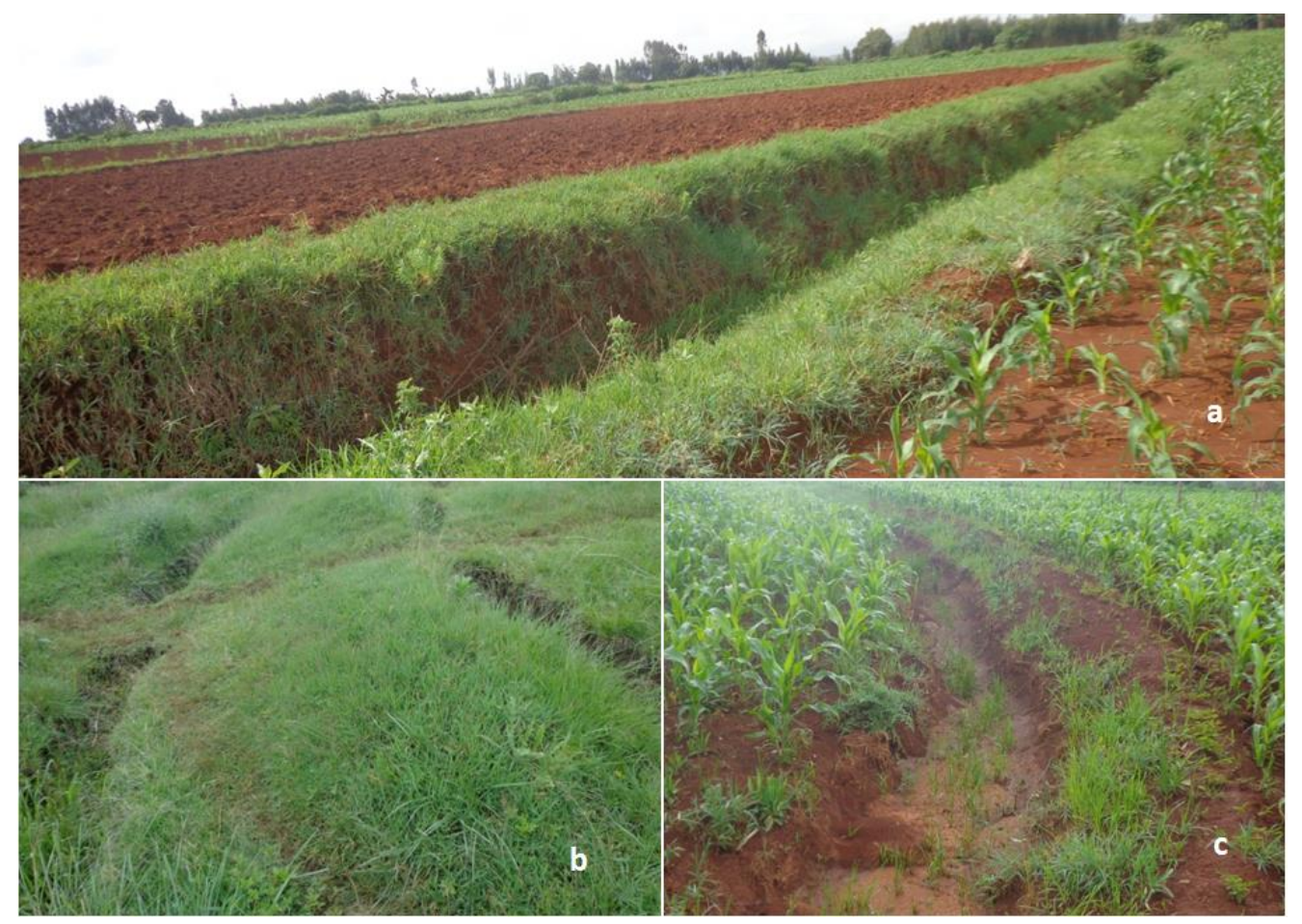

Figure 6.2 Sample pictures of a fanya juu (a), micro-trenches (b) and a soil bund (c) structures implemented for sediment trapping at Minizr catchment 


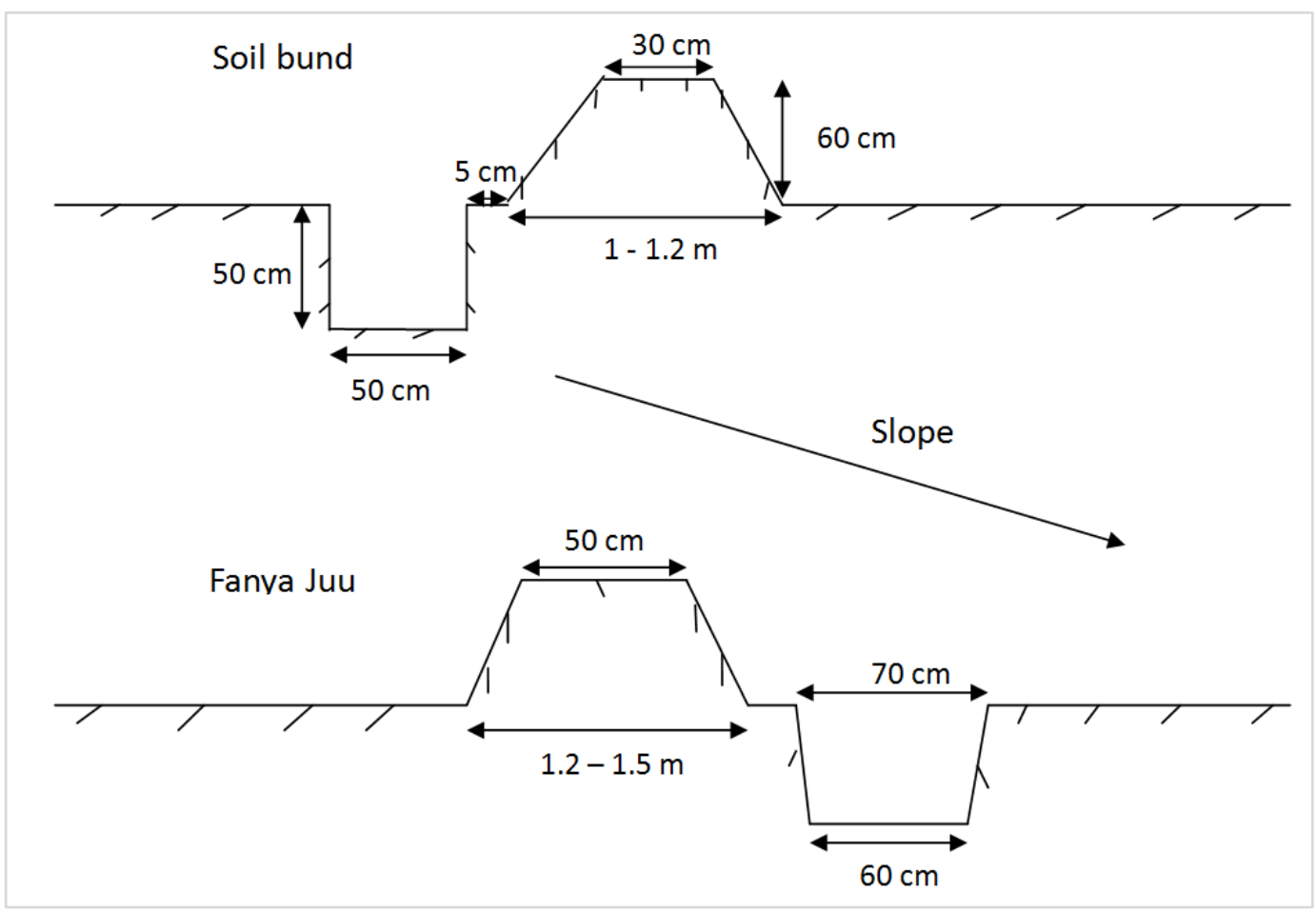

Figure 6.3 Schematic diagram showing a soil bund (erken; upper) and fanya juu (cab; lower) operate to trap sediment from upslope. Both of them are positioned perpendicular to the slope and runoff direction, thereby maximizing sedimentation and infiltration of surface runoff

According to Lakel et al. (2010) and Slattery et al. (2002), sediment pins and direct measurements of the sedimentary deposit can be used to quantify the amount of sediment in the sediment sinks. In this study, sediment pins and vertical cut measurements of the deposited sediment were used to measure the depth of sediment trapped by the SWC structures. Over a two-year period (2014 and 2015), a total of 214 depth measurements were recorded ( 72 from soil bunds; 72 from fanya juu and 70 from micro-trenches).

When selecting which soil bund and fanya juu ridge to sample, three slope classes were considered: $<5 \%$ (lower), $5-7 \%$ (middle) and $>7 \%$ (upper). Sampling sites were replicated three times for each of the three slope classes while three soil bunds and three fanya juu ridges were also evaluated.

The deposited sediment was measured for the nine 30 meter soil bunds. Sediment depth was recorded at four representative locations (every $10 \mathrm{~m}$ distance along each bund) resulting in 36 measurements in 2014 and 72 in 2015. Similarly, nine representative fanya juu ridges (30 m each) were selected. Before the rainy season, 36 sediment pins ( $10 \mathrm{~m}$ spacing, 4 sediment pins per ridge) were installed, with the depth of sediment measured at the end of the rainy season in 2014 and 2015. In total 72 depths were collected over the two years. Sedimentation width of fanya juu ridges ranged from 0.3-0.9 $\mathrm{m}$ with an average of $0.6 \mathrm{~m}$. In addition to sediment pins, vertical cut measurements through the deposited sediment were taken upslope of the fanya juu ridge to increase the accuracy of the data. To calculate the total volume of the trapped sediment, the average 
depth and width of sedimentation of the two SWC structures (fanya juu and soil bunds) were multiplied by their total length within the catchment.

A sub-catchment containing SWC structures (soil bunds and fanya juu) was selected to evaluate the STE of the structures. Sediment outflow at the outlet of the sub-catchment was measured including sediment trapped by SWC structures within the sub-catchment, which was categorized as inflow sediment. STE was calculated (Eq. 6.1) based on sediment inflow and outflow (Verstraeten \& Poesen, 2000; Mekonnen et al., 2015b) using,

$S T E=\frac{\left(S_{\text {inflow }-} S_{\text {outflow }}\right)}{S_{\text {inflow }}} * 100$

where: $S T E$ is sediment trapping efficacy (\%); $S_{\text {inflow }}$ is the sum of the outflow sediment measured at the outlet of the sub-catchment and sediment trapped by SWC structures $(\mathrm{kg})$ and $S_{\text {outflow }}$ is sediment measured at the outlet of the sub-catchment $(\mathrm{kg})$

Micro-trenches on average are $1.5 \mathrm{~m}$ long and $0.4 \mathrm{~m}$ wide. Thirty micro-trenches were selected with trapped sediment depth determined by measuring the depth of micro-trenches before and after the rainy seasons in 2014 and 2015. In addition, five sediment pins were used in five micro-trenches to measure trapped sediment depth more accurately resulting in 70 sediment depth measurements. To quantify the volume of trapped sediment in a micro-trench, the average measured sedimentation depth was multiplied by the width and length of the structure, which was multiplied by the total number of micro-trenches implemented in the study area.

\section{Measuring sediment trapped on the floodplain}

Sediment trapped on the floodplain was quantified using sediment pins and direct measurements of sediment depth (Riihimaki, 2011). Thirty sediment pins were installed inside the 17 ha floodplain area (Figure 6.1) before the rainy seasons and measured after the rainy seasons in 2014 and 2015. In addition eight vertical cut measurements of the deposited sediment were done every year. A total of 76 depth samples (16 direct samples and 60 buried pin depths) were taken over two years. To calculate the annual volume of trapped sediment, the average sedimentation depth was multiplied by the floodplain area.

To evaluate the STE of the floodplain, a total of 48 suspended sediment samples ( 24 composite inflows and 24 outflows in 2014 and 2015) were collected from 24 rainfall events (12 rainfall events each year). Two runoff inflow temporary streams through which the majority of the runoff enters onto the floodplain and one outflow/outlet were used to collect suspended sediment samples. The STE of the floodplain was calculated based on the measured inflow and outflow of sediment (Eq. 6.1). 


\section{Measuring sediment trapped in the wetland}

Over three years (2013-2015), a total of 48 composite suspended sediment samples were collected at four inflow locations, while 48 samples were collected at the main outflow (16 samples each year). The reason being that runoff enters the wetland through four temporary drainage channels and exits the wetland through a single channel (Figure 6.4). Sediment trapping efficacy (STE) of the wetland was calculated based on the measured inflow and outflow of suspended sediment (Line et al., 2008) (Eq. 6.1).

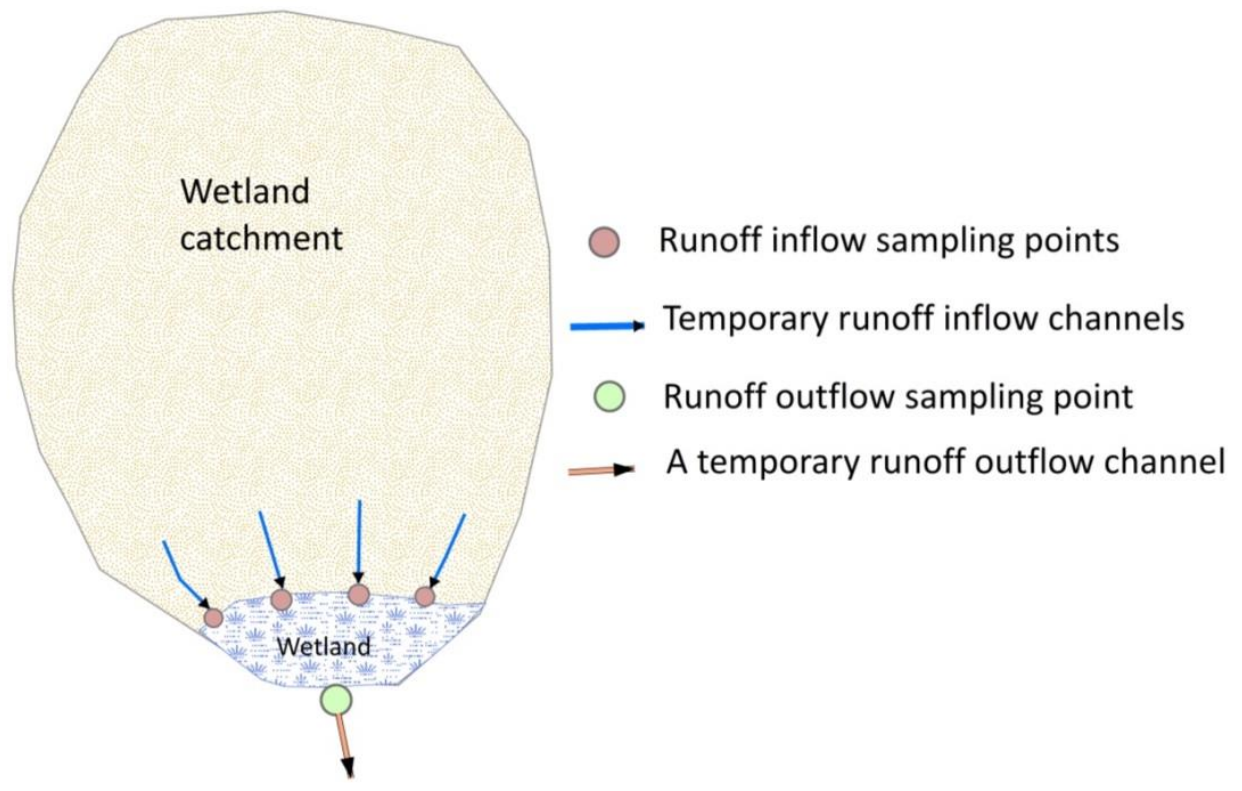

Figure 6.4 Schematic diagram of the wetland area showing the inflow and outflow of runoff and the locations of the suspended sediment collection sites within the Minizr catchment.

Although suspended sediment samples were collected at the inflow and outflow points of the wetland, it was not possible to estimate the total amount of sediment that enters into the wetland since it was difficult to accurately measure and quantify the inflow runoff entering the wetland through the four temporary inflow channels. Hence, the sediment trapping inefficacy (STI) and the un-trapped sediment that passed through the wetland were used to calculate the trapped sediment contribution using Eqs. 6.2 and 6.3,

$\operatorname{STI}(\%)=100-\operatorname{STE}(\%)$

$T S=\frac{S T E(\%) * U T S}{S T I(\%)}$

where: TS is the amount of wetland sediment trapped ( $t$ ) and UTS is the amount of un-trapped sediment that passed through the wetland $(\mathrm{t})$.

To quantify the un-trapped sediment that passed through the wetland, both runoff and suspended sediment data were collected at the outlet of the wetland. Runoff depth was measured using a pressure transducer (diver) while channel width was measured using a tape measure. Runoff velocity 
$\left(\mathrm{m} \mathrm{s}^{-1}\right)$ was measured using the Valeport 'Braystoke' Model 001 current meter. The velocity/area method (FAO, 1993) was used to estimate total runoff discharge (Eq. 6.4), while sediment discharge was calculated from suspended sediment concentration samples (Blanchard et al., 2011) (Eq. 6.5),

$Q=A \times V$

$\mathrm{Q}_{\mathrm{s}}=\mathrm{Q} * \mathrm{C}_{\mathrm{s}} * \mathrm{~K}$

where: $Q$ is runoff discharge in $\mathrm{m}^{3} \mathrm{~s}^{-1} ; A$ is channel cross sectional area $\left(\mathrm{m}^{2}\right)$ and $V$ is flow velocity ( $\mathrm{m}$ $\left.\mathrm{s}^{-1}\right) ; \mathrm{Q}_{\mathrm{s}}$ is sediment discharge $\left(\mathrm{t} \mathrm{day}^{-1}\right) ; \mathrm{C}_{\mathrm{s}}$ is concentration of suspended sediment $\left(\mathrm{g}^{-1}\right)$ and $\mathrm{K}$ is 86.4, which is the conversion coefficient.

\section{Measuring suspended sediment in a grassed waterway}

Grassed waterways are areas where runoff concentrates over grassed areas rather than on bare erodible soil. Grasses enhance infiltration of the runoff and their roots bind the soil and help protect it from erosion. They also help to reduce sediment transport through decreasing flow velocity (Fiener \& Auerswald, 2006; Dermisis et al., 2010; Mekonnen et al., 2015a), and are very efficient at filtering runoff and contributing to nutrient and sediment deposition. Both grassed and un-grassed waterways discharge runoff within the Minizr catchment. Therefore, two natural waterways, one covered with grass (grassed waterway) and one devoid of grass cover (un-grassed waterway) were investigated for this study.

To evaluate the suspended sediment load reduction and STE of both waterways, 60 suspended sediment samples ( 30 inflow and 30 outflow) were collected in 2014 and 2015 in both the grassed and un-grassed waterways with their STEs calculated using Eq. 6.1. The grassed and un-grassed waterways were located at the outlet of two small adjacent catchments covering an area of 2.12 and $2.18 \mathrm{~km}^{2}$, respectively. The catchments have similar rainfall, soil type, land use/cover and slope characteristics. The grassed waterway is $1023 \mathrm{~m}$ long while the un-grassed waterway has a length of $1016 \mathrm{~m}$, both with an average width ranging from 2.6-3.0 $\mathrm{m}$ (Figure 6.1).

\section{Dry mass and sediment density calculation}

To convert the trapped (deposited) sediment volume to dry sediment mass, the density of the trapped sediment was estimated using the cylindrical core method (McKenzie et al., 2002; Mekonnen et al., 2015b). Six samples from the floodplain, six from micro-trenches and 12 from SWC structures, each of $100 \mathrm{~cm}^{3}$, were collected. The samples were oven dried at $105{ }^{\circ} \mathrm{C}$ in the laboratory for 24 hours, with dry sediment calculated by weighing the dry sediment and subtracting it from the wet sediment mass. Dry mass of the collected suspended sediment samples at the inflow and outflow locations of the wetland, floodplain and waterways was determined in a similar manner. Density was calculated by dividing the dry sediment mass by volume. 


\section{Statistical analysis}

Data analysis was done using Microsoft Excel and IBM SPSS statistics 22 software. ANOVA was run to evaluate differences in sedimentation rates for the different slope classes (upper, middle and lower) in the catchment and to compare the means of trapped sediment by soil bund and fanya juu ridges.

\subsection{Results}

\section{Sediment trapped by SWC structures}

In the Minizr catchment, there are $144 \mathrm{~km}$ of soil bunds and fanya juu ridges. Overall, the mean measured rate of sedimentation from the sampled soil bunds and fanya juu ridges was $0.053 \mathrm{~m}^{3} \mathrm{~m}^{-1}$ $\mathrm{y}^{-1}$ or $55 \mathrm{~kg} \mathrm{~m}^{-1} \mathrm{y}^{-1}$, with an average depth of $0.09 \mathrm{~m}$. Furthermore, the rate of sedimentation was not significantly different at $\mathrm{P}<0.05$ in the upper, middle and lower parts of the catchment and between the soil bunds and fanya juu ridges (Table 6.1). The total annual sediment trapped was $7,620 \mathrm{~m}^{3}$ or $7,922 \mathrm{Mg}$ (using an average bulk density of $1.04 \mathrm{~g} \mathrm{~cm}^{-3}$ ), resulting in a STE of $54 \%$. All micro-trenches (576 in total) constructed on grazing lands trapped $13 \mathrm{~m}^{3} \mathrm{y}^{-1}$ or $13.26 \mathrm{Mg} \mathrm{y}^{-1}$ (using an average bulk density of $1.02 \mathrm{~g} \mathrm{~cm}^{-3}$ ), with each individual micro-trench trapping $23 \mathrm{~kg}$ of sediment annually.

Table 6.1 Catchment sedimentation within a sample of fanya juu and soil bund structures

\begin{tabular}{|c|c|c|c|c|c|}
\hline \multirow{2}{*}{ Structure $^{A}$} & \multirow{2}{*}{$\begin{array}{l}\text { Position in the } \\
\text { catchment }^{B}\end{array}$} & \multirow{2}{*}{$\begin{array}{l}\text { Sediment } \\
\text { depth }^{c} \\
\text { (m) }\end{array}$} & \multirow{2}{*}{$\begin{array}{c}\text { Total } \\
\text { sedimentation }^{D} \\
\left(\mathrm{~m}^{3} 30 \mathrm{~m}^{-1}\right)\end{array}$} & \multicolumn{2}{|c|}{ Rate of sedimentation ${ }^{\mathrm{E}}$} \\
\hline & & & & $\left(m^{3} m^{-1} y^{-1}\right)$ & $\left(\mathrm{kg} \mathrm{m}^{-1} \mathrm{y}^{-1}\right)$ \\
\hline Fanya juu & Upper & 0.11 & 1.92 & $0.064^{a}$ & $65.28^{a}$ \\
\hline Fanya juu & Middle & 0.09 & 1.68 & $0.056^{a}$ & $57.12^{\mathrm{a}}$ \\
\hline Fanya juu & Lower & 0.10 & 1.74 & $0.058^{a}$ & $59.16^{a}$ \\
\hline Soil bunds & Upper & 0.08 & 1.20 & $0.040^{a}$ & $40.80^{a}$ \\
\hline Soil bunds & Middle & 0.10 & 1.50 & $0.050^{a}$ & $51.00^{a}$ \\
\hline Soil bunds & Lower & 0.11 & 1.65 & $0.055^{a}$ & $56.10^{a}$ \\
\hline Average & - & 0.09 & 1.60 & 0.053 & 55.00 \\
\hline \multicolumn{6}{|c|}{ A Average sedimentation width is $0.6 \mathrm{~m}$ (fanya juu); $0.5 \mathrm{~m}$ (soil bund) and ditch length is $30 \mathrm{~m}$. } \\
\hline \multicolumn{6}{|c|}{${ }^{B}$ Position and slopes in the catchment; Upper (>7\%), Middle $(5-7 \%)$ and Lower $(<5 \%)$ slopes. } \\
\hline \multicolumn{6}{|c|}{${ }^{\mathrm{C}}$ Two years average deposited sediment depth. } \\
\hline \multicolumn{6}{|c|}{${ }^{\mathrm{D}}$ Two years average sediment deposited behind $30 \mathrm{~m}$ structures. } \\
\hline \multicolumn{6}{|c|}{${ }^{\mathrm{E}}$ Two years average rate of sedimentation. } \\
\hline
\end{tabular}

\section{Sediment trapped on the floodplain}

Over 2014 and 2015, the average inflow, outflow and sediment trapped by the floodplain were 15.9 $\mathrm{gl}^{-1}, 3.7 \mathrm{gl}^{-1}$ and $12.2 \mathrm{gl}^{-1}$, respectively, with STE calculated at $77 \%$. Thus a total of $12,950 \mathrm{Mg} \mathrm{y}^{-1}$ of soil was eroded from the upper catchment and transported onto the floodplain. On the 17 ha floodplain, $8,670 \mathrm{~m}^{3}$ or $9,970 \mathrm{Mg}$ of sediment (using a bulk density of $1.15 \mathrm{~g} \mathrm{~cm}^{-3}$ ) was trapped at a sediment depth of $5.1 \mathrm{~cm}$, and an average sedimentation rate of $59 \mathrm{~kg} \mathrm{~m}^{-2} \mathrm{y}^{-1}$. Although $77 \%$ of the 
inflow sediment was trapped, $23 \%$ was transported downstream through the floodplain, which amounts to $2,590 \mathrm{~m}^{3} \mathrm{y}^{-1}$ or $2,980 \mathrm{Mg} \mathrm{y}^{-1}$.

\section{Sediment trapped in the wetland}

In the wetland, over the three years (2013 - 2015), the average inflow, outflow and trapped sediment was $6.7 \mathrm{~g} \mathrm{I}^{-1}, 1.0 \mathrm{~g} \mathrm{I}^{-1}$ and $5.7 \mathrm{~g} \mathrm{l}^{-1}$, respectively, with the STE of the wetland being $85 \%$. The average annual volume of sediment trapped and accumulated in the wetland was $8,715 \mathrm{Mg}$ with a sedimentation rate of $36 \mathrm{~kg} \mathrm{~m}^{-2} \mathrm{y}^{-1}$. The remaining $15 \%$ of the sediment or $1,540 \mathrm{Mg} \mathrm{y}^{-1}$, was annually transported downstream through the wetland. Therefore, $10,250 \mathrm{Mg}^{-1}$ of soil was eroded from the upper catchment and transported into the wetland.

\section{Sediment trapped in waterways}

The average inflow, outflow and trapped sediment over 2014 and 2015, respectively, was $5.6 \mathrm{~g} \mathrm{I}^{-1}$, $1.4 \mathrm{gl}^{-1}$ and $4.2 \mathrm{~g} \mathrm{l}^{-1}$ (grassed waterway) and $5.6 \mathrm{gl}^{-1}, 4.4 \mathrm{gl}^{-1}$ and $1.2 \mathrm{gl}^{-1}$ (un-grassed waterway); with STEs of $75 \%$ and $21 \%$ for the grassed and un-grassed waterways, respectively. The grassed waterway reduced suspended sediment content of the runoff three times more than the un-grassed waterway. This is clearly evident in Figure 6.5 which shows the junction between low sediment-laden runoff at the end of the grassed waterway on the left (a), and the high sediment-laden runoff at the end of the un-grassed waterway (b) on the right.

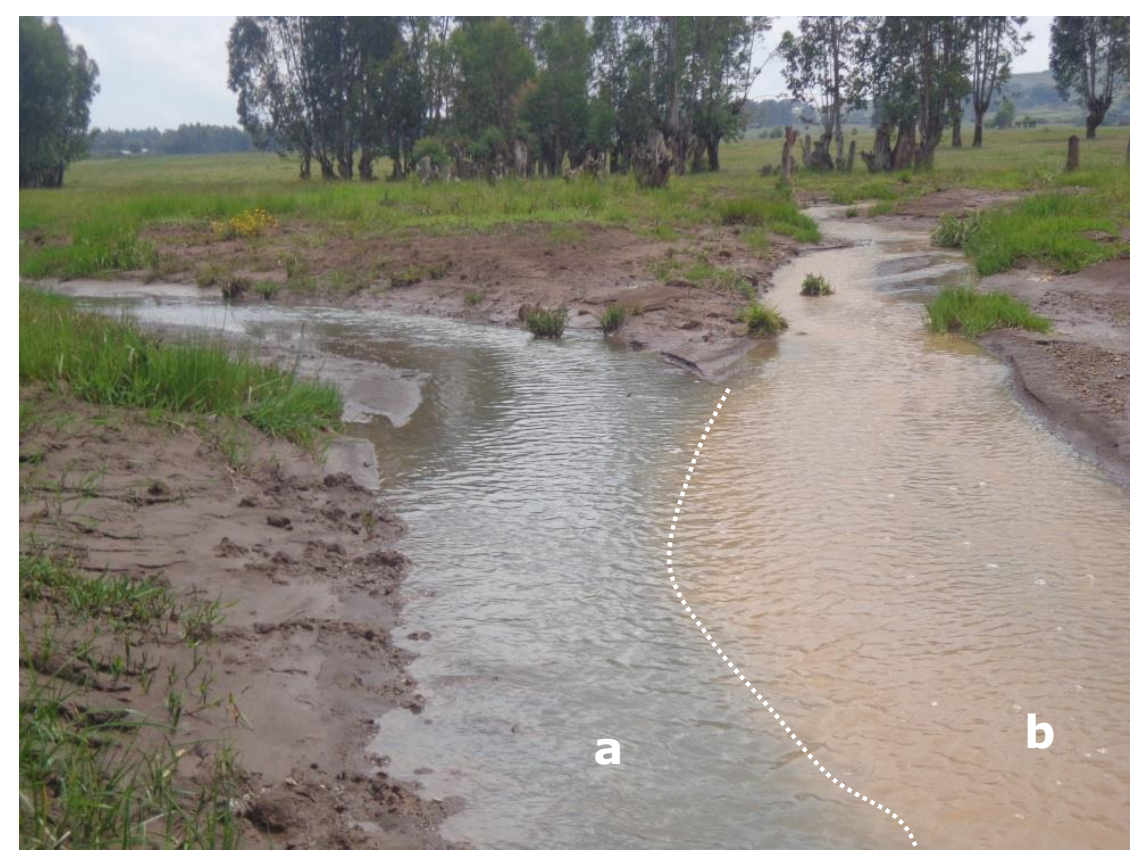

Figure 6.5 Difference in sediment content in the runoff is reflected in differences in sediment loads at the junction between the grassed $(A)$ and un-grassed $(B)$ waterways. 


\subsection{Discussion}

\section{Sediment trapping by man-made SWC structures}

In the Minizr catchment, the rate of sedimentation caused by soil bunds and fanya juu ridges, was on average $55 \mathrm{~kg} \mathrm{~m}^{-1} \mathrm{y}^{-1}$ with STE 54\%. This finding agrees with (Lecce et al., 2006), who found drainage ditch sedimentation rates ranging from 12.5 to $88.8 \mathrm{~kg} \mathrm{~m}^{-1} \mathrm{y}^{-1}$ in North Carolina.

However, according to (Gebremichael et al., 2005), in the northern part of Ethiopia (Dogua Tembien district), the rate of sedimentation behind stone bunds was $119 \mathrm{~kg} \mathrm{~m}^{-1} \mathrm{y}^{-1}$, which is much higher than the results obtained in this study. Differences in the rate of on-site soil erosion can significantly affect the inflow of sediment into the structures. Soil erosion in the Dogua Tembien district was much higher $\left(57 \mathrm{Mg} \mathrm{ha}^{-1} \mathrm{y}^{-1}\right)$ than in the Minizr catchment $\left(21.5 \mathrm{Mg} \mathrm{ha}^{-1} \mathrm{y}^{-1}\right)$. In general, SWC structures constructed within fields were found to trap large amounts of sediment and made a major contribution to the reduction of sediment entering the Koga reservoir at the catchment outlet.

SWC structures reduce the slope gradient of farmland by forming bench terraces as a result of sediment accumulation (Gebremichael et al., 2005; Mekonnen et al., 2015b). In the study area, even though no statistically significant difference was found in the rate of sedimentation between soil bunds and fanya juu ridges at different slopes, 20 year old fanya juu form high sediment ridge lines because the trapped sediment have gradually converted them into bench terraces (Figure 6.2a). This decreased average slope gradients by $2.7 \%$. However, soil bunds do not alter the slope gradient largely because the trapped sediment is buried inside the ditch instead of forming a sediment ridge in front of the structure.

\section{Sediment trapping - natural sediment sinks}

In the study area, natural sediment sinks played an important role in trapping sediment and reducing downstream reservoir sedimentation. The 24 ha wetland located near the outlet of the Minizr catchment (Figure 6.1) trapped $8,715 \mathrm{Mg}$ of sediment annually at an average sedimentation rate of $36 \mathrm{~kg} \mathrm{~m}^{-2} \mathrm{y}^{-1}$ with a STE of $85 \%$. This result agrees well with the literature. Braskerud (2001) found for constructed wetlands in southeast Norway, sedimentation rates of $14-121 \mathrm{~kg} \mathrm{~m}^{-2} \mathrm{y}^{-1}$. Elder and Goddard (1996) obtained a STE of $80 \%$ at the Jackson Creek wetland in Wisconsin, while the Imperial Valley wetland in California had a STE of 97\% (Kadlec et al., 2010). Other constructed wetlands revealed STEs of 71-90\% in southern Brazil (Sezerino et al., 2012), and 72-88\% in North Carolina (Line et al., 2008). Variations in these ranges are largely due to the natural morphology and size of the wetlands and vegetation species composition and diversity, which all have an important influence on the STE of the wetland in reducing erosion and enhancing deposition (Braskerud, 2001; Berendse et al., 2015; Mekonnen et al., 2015a).

According to Keesstra (2007) and Keesstra et al. (2009a), sediment deposition on a floodplain depends on the location of the floodplain within the catchment and also on the width and land cover of the floodplain. In addition, sediment influx from hillslopes and the intensity of rainfall, all play a role in governing the potential of a floodplain or wetland to trap incoming sediment. In this study, a $696 \mathrm{~m}$ long and $243 \mathrm{~m}$ wide floodplain, which was covered with grass, trapped 9,970 Mg of sediment 
annually with a STE of $77 \%$ and an average sedimentation rate of $59 \mathrm{~kg} \mathrm{~m}^{-2} \mathrm{y}^{-1}$. This result is in line with Brunet and Astin (2008), who found sedimentation rates on floodplains in southwest France ranging from $0.02-75 \mathrm{~kg} \mathrm{~m}^{-2} \mathrm{y}^{-1}$.

Sediment load reduction in grassed waterways ranged from 65\% (Dermisis et al., 2010) to $97 \%$ (Fiener \& Auerswald, 2003). In this study, sediment discharge decreased by $75 \%$ between the grassed waterway inflow and outflow. Sediment reduction was considerably higher in grassed waterways than in un-grassed waterways (21\%). In addition to trapping sediment, grass cover decreased the propensity for scour, deepening and widening of the waterway by erosion, further reducing the sediment yield from the catchment area.

Although the wetland plays an important role in trapping sediment, floodwaters will inundate the wetland, which over time, will be converted into farmland due to the persistent sediment accumulation. According to Wang et al. (2014), watershed management designed to reduce sediment input into the wetland may aid in the conservation of natural wetlands. Therefore, emphasis should be given to man-made ST measures on fields in the upper catchment to help trap and reduce sediment input into the wetland.

Agricultural expansion has also strongly affected the existence of the wetland which has been given to landless youths to cultivate and grow crops. They are slowly converting the wetland into farmland by draining the wetland water and ploughing it. This will destroy the wetland and its ecosystem in a very short period of time. As an alternative, instead of cultivating the wetland area for crop production, the youths could use the grass growing on the wetland for livestock fattening, as a means of generating income without affecting the wetland. Therefore, awareness raising of policy makers, the surrounding farmers and youth associations is needed to sustainably conserve and manage the wetland.

\section{Disconnecting sediment transfer pathways}

Connectivity is an emerging issue of a catchment system (Bracken et al., 2015; Parsons et al., 2015), which indicates how well a system transfers substances, such as water and sediment, through it. The combined effect of ST measures both on- and off-site will reduce the connectivity of the landscape and sediment transfer pathways within the catchment (Mekonnen et al., 2014b).

The possibility for sediment to be trapped within the catchment is enhanced by the appropriate placement of barriers and buffers, which can reduce sediment connectivity (Fryirs, 2012). According to Baartman et al. (2013), man-made structures like terraces are reducing sediment delivery to the outlet. Cerda et al. (2015) and Keesstra et al. (2016) have shown that leaving mulch within the catchment can reduce the amount of sediment transported to the catchment outlet. Furthermore, reducing the input of sediment from roads as a significant sediment contributor (Pereira et al., 2015) to the total sediment budget, is needed as part of an integrated approach to the whole catchment system. In addition, studies on the impact of plant species (Novara et al., 2013; Mekonnen et al., 2015a) and plant species diversity (Berendse et al., 2015), reveal that by effectively managing plant cover, sediment can be trapped more effectively and that soil erosion can be further reduced. 
By utilizing scientific agricultural practices, appropriate SWC measures, and the effective management of the land with suitable plant species, sediment yield at the catchment scale can be reduced. In this study, SWC measures and natural sediment sinks (floodplain and wetland) trapped considerable quantities of sediment by disconnecting the sediment transfer paths within the catchment. SWC structures such as Fanya juu, played an important role in disconnecting the landscape by forming ridges due to the accumulated sediment, which further reduced the slope gradient.

\section{Integrated sediment trapping}

According to Mekonnen et al. (2014b), an integrated ST approach at the catchment scale is believed to be the most effective way in helping to increase the STE of ST measures and thereby reducing sediment loads at the outlet of a catchment. On-site ST measures can help maintain sediments on agricultural field sites, while off-site ST measures trap sediments in drainage channels and gullies. Sediments transported from farmlands without being trapped by on-site ST measures can be trapped by off-site ST measures.

In the Minizr catchment, despite the presence of numerous man-made ST structures and natural sediment sinks trapping large quantities of sediment $(26,600 \mathrm{Mg})$, this only amounts to $38 \%$ of the total sediment load, with the vast majority (62\%) being deposited in the Koga reservoir $(43,000 \mathrm{Mg})$. There are three reasons for this:

(i) more emphasis is given to managing on-site sediment sources when implementing SWC structures within fields, without addressing gully erosion or riverbank erosion, which are both important sediment sources in the catchment. According to Mekonnen et al. (2014a) and Rijkee et al. (2015), river bank and gully erosion are severe and represent an important source of sediment.

(ii) Structural SWC measures are not fully supported with vegetative measures such as grass species, which can help improve STE. To effectively trap sediment and ensure the sustainability of ST structures, it is important to combine both vegetative and structural measures (Nyssen et al., 2009b; Mekonnen et al., 2014b).

(iii) Lack of regular maintenance and free grazing are causing SWC structural failures, which affect STE and reduce the sustainability of SWC structures.

To effectively trap sediment within the catchment and further reduce sediment entering the Koga reservoir, an integrated ST approach is needed. This includes:

(i) implementing off-site ST measures such as check dams and sediment storage dams (SSD) inside gullies and within drainage lines as SSDs constructed inside drainage lines and gullies can trap 67-74\% of incoming sediment (Mekonnen et al., 2015b);

(ii) implementing riparian zone measures such as establishing buffer zones and planting trees along the river to reduce riverbank erosion, because vegetation causes flow retardation within the channel and on the riverbanks and thus enhances sedimentation (Keesstra et al., 2012);

(iii) managing sediment access paths; and,

(iv) conducting regular maintenance of structures and avoiding free grazing. 


\section{Using vegetative measures instead of physical structures}

In the Minizr catchment, $144 \mathrm{~km}$ of SWC structures (fanya juu and soil bund) have been constructed in farmlands to trap sediment and thus help reduce soil loss. To construct this length of structure 69, $000 \mathrm{~m}^{3}$ soil was moved from its original location either upslope (fanya juu) or downslope (soil bunds), which involved 25, 000 human labour days (work norm: 175 person day per km; (MOARD, 2005)). This process increased soil instability and facilitated soil loss, in addition to consuming large amounts of labour. To avoid this problem, vegetative ST measures were seen as better alternatives. According to Mekonnen et al. (2015a), grass barriers can trap from $20-76 \%$ of the inflow sediment on an $8 \%$ slope. Moreover, grass barriers can solve livestock feed problems, which is a crucial issue in both the study area and in Ethiopia in general.

\subsection{Conclusions}

The STE of existing man-made structures and natural sediment sinks were evaluated in the Minizr catchment, northwest Ethiopia. They play a significant role in trapping sediment and disconnecting sediment transfer pathways. Rates of sedimentation were $55 \mathrm{~kg} \mathrm{~m}^{-1} \mathrm{y}^{-1}$ for SWC structures (soil bunds and fanya juu), $59 \mathrm{~kg} \mathrm{~m}^{-2} \mathrm{y}^{-1}$ on the floodplain and $36 \mathrm{~kg} \mathrm{~m}^{-2} \mathrm{y}^{-1}$ in the wetland, while $>576$ individual micro-trenches can trap $23 \mathrm{~kg}$ of sediment annually. Over 20 years old, fanya juu ridges have reduced the average slope gradient by $2.7 \%$ forming lines of high sediment ridges. In soil bunds, trapped sediment is buried inside a ditch instead of forming lines of sediment ridges, which reduces its role in changing the gradient of the slope. Wetlands, floodplains, grassed waterways and SWC structures (soil bunds and fanya juu) were found to be effective sediment sinks with STEs of $85 \%, 77 \%, 75 \%$ and $54 \%$, respectively. Despite $26,600 \mathrm{Mg}(38 \%)$ of sediment being trapped by both the existing manmade structures (soil bunds, fanya juu and micro-trenches) and natural sediment sinks (wetland and floodplain), there is still $43,000 \mathrm{Mg}(62 \%)$ leaving the catchment and entering Koga reservoir as suspended sediment. Soil eroded within a catchment is very rarely transported in its entirety to the outlet, as a portion of it will be trapped and re-deposited within the catchment either due to manmade SWC structures or by natural sediment sinks.

This study shows that large amounts of money and labour are being invested to implement ST measures aimed at reducing soil loss by enhancing sedimentation within a catchment. Still large amounts of sediment are leaving the catchment and entering Koga reservoir. This is also a great challenge to reservoirs, which are under construction for hydropower generation involving large investments such as the Ethiopian Grand Renaissance Dam, and natural reservoirs like Lake Tana. Therefore, additional catchment treatment measures are required with an integrated catchment scale ST approach to help reduce sediment loads into Koga reservoir. 


\section{Chapter 7}

\section{Adapting LAPSUS_D model to simulate runoff and sediment yield in Minizr catchment, NW Ethiopia}

Mulatie Mekonnen Getahun 


\title{
Adapting LAPSUS_D model to simulate runoff and sediment yield in Minizr catchment, NW Ethiopia
}

\begin{abstract}
Direct field measurements and model simulations can be used to determine catchment sediment yield. Estimating catchment runoff and sediment yields using model simulation helps to save resources compared with field data measurements. A further advantage of using a modelling approach is the ability to assess, apriori (i.e. before actual implementation), the effect of different spatial configurations of the various sediment trapping measures in the catchment and chose the optimal design. Moreover, models help to simulate the effectiveness of sediment trapping measures at larger catchment scales, which cannot be feasibly achieved by field experiments. In this study, we tried to adapt the daily based model, which require low input data sets, LAPSUS_D, for the northwest highlands of Ethiopia. We used the three years runoff and sediment yield data (Chapter 2) collected at the outlet of the Minizr catchment, northwest Ethiopia, to calibrate and validate the model. However, the result was not promising. The most probably reasons of the poor representation of the data is the quality of the DEM. The resolution of $30 \mathrm{~m}$ does not able to represent the small scale variations in the catchment such as the large number of gullies. Furthermore, a large part of the catchment is very flat in terms of topography and therefore small errors in the DEM have a large influence on the representation of the hydrology in the catchment. As a result of this the water was not routed through the catchment as it is in reality. Further study is recommended with a DEM of better resolution.
\end{abstract}

\subsection{Introduction}

Reservoir sedimentation resulting from upstream soil erosion is a critical problem affecting the water storage capacity of water reservoirs in Ethiopia. Many reservoirs are losing their water storage capacity (Haregeweyn et al., 2006; Tamene et al., 2006a). This risk is poorly addressed because of lack of sufficient data and appropriate methodologies to predict sediment yield (Haregeweyn et al., 2006) and lack of an integrated catchment scale sediment trapping approach (Mekonnen et al., 2014b).

To overcome these problems to predict catchment sediment yield, attempts have been made to adapt and use process-based models in Ethiopia. Some examples of models that have been used to predict catchment sediment yield are: Water Erosion Prediction Project (Zeleke, 2000) and Soil and Water analysis Tool (Setegn et al., 2010) at Anjeni catchment, northwest Ethiopia, and the Agricultural Non-Point Source Pollution model (Haregeweyn \& Yohannes, 2003) at Augucho catchment, eastern Ethiopia. However, such models require large input datasets and if such models are applied in conditions where the necessary data are not available and, therefore, a proper calibration cannot be performed, the results may become unreliable (Nyssen et al., 2006; Haregeweyn et al., 2013). Consequently, such models may be accurate but their complexity and data demand may reduce their usability. Therefore, models requiring minimal and easily accessible input datasets are best alternatives in data scarce countries like Ethiopia. 
Research on catchment sediment dynamics has generally focused on large or small scales both spatially and temporally, largely ignoring the intermediate scale (Gao \& Josefson, 2012; Keesstra et al., 2014a; Yeshaneh et al., 2014). But from an applied (management) perspective, the intermediate scale (meso-scale) is the scale at which catchment managers most often take decisions (Aksoy \& Kavvas, 2005) and the temporal (daily) scale is the one for which most hydrological data are recorded (Higgitt \& Lu, 2001; Newham et al., 2004; Keesstra et al., 2014a).

In a meso-scale catchment $\left(20-200 \mathrm{~km}^{2}\right)$ overland flow was assumed to reach the outlet of the catchment in one day, which makes possible to estimate daily discharge. According to Keesstra et al. (2014a), daily discharge is better than annual discharge because of two reasons; (i) it is a good indication of the amount of overland flow in the catchment, and with that a good indication of sediment transport capacity, and (ii) daily discharge data are usually available for most catchments and can therefore be used in calibration and validation.

Compared to the average annual sediment yield values, monthly and daily based values could provide valuable detailed information about the temporal and spatial variations of catchment sediment yield (chapter 2). Annual sediment yield data $\left(\mathrm{t} \mathrm{ha}^{-1} \mathrm{y}^{-1}\right)$ is not informative to where the sediment sources are located and at which moments in time the sediment is discharged from the catchment. Only a small part of the catchment (Mekonnen \& Melesse, 2011) and only a few heavy rain storms on specific dates usually produce the bulk of annual sediment yield (Hagmann, 1996; Ziadat \& Taimeh, 2013).

In addition to sediment yield data, information is required on the actual sediment source areas, areas where most soil erosion occurs and sediment sink areas, areas where most sediment deposition takes place. Identifying major sediment source areas will help to intervene the problem of soil erosion allocating the available resources to high risk areas instead of spreading it equally all over the catchment (Mekonnen \& Melesse, 2011; Haregeweyn et al., 2013).

Spatially distributed models help to indicate where erosion and deposition occurs within a catchment. The LAPSUS (LAndscape ProcesS modelling at mUlti dimensions and scaleS) model has been previously tested in several field studies on erosion and sedimentation in varying climates (Schoorl et al., 2002; Haileslassie et al., 2005; Baartman et al., 2013; Barreto et al., 2013). These studies used the original LAPSUS model, based on yearly timesteps. To fill this scientific and management gap, the landscape evolution model LAPSUS was adapted as LAPSUS_D for a meso-scale catchment to model runoff and sediment yield on a daily resolution (Keesstra et al., 2014a). In this study, the LAPSUS_D model is used to assess hydrology and sediment dynamics for the Minizr catchment in northwest Ethiopia.

The specific objectives of this study were to, (I) adapt the LAPSUS_D model and predict daily runoff and sediment yield in the $20 \mathrm{~km}^{2}$ Minizr catchment, in northwest Ethiopia, (II) to identify erosion hotspot (sediment source) areas for intervention measures, (III) assess, the effect of different spatial configurations of the various sediment trapping measures in the catchment and chose the optimal 
design by running scenarios using the model. The scenarios consist of a different combination of measures on various locations within the catchment, (IV) evaluate potential sediment yield reduction of an integrated sediment trapping approach.

\subsection{Materials and methods}

\section{Study area}

The study was conducted in the Minizr catchment, northwest highlands of Ethiopia (1255891 $1249499 \mathrm{~N}$ and 310272 - 303559 E; Adindan_UTM_Zone_37N; Figure 7.1). It covers an area of about $20 \mathrm{~km}^{2}$ with an elevation range of $2035 \mathrm{~m}$ at the outlet to $2283 \mathrm{~m}$. a.s.l. at its highest point on the catchment divide. Slope in the catchment ranges from $0-51 \%$ with an average value of $8 \%$. More than $80 \%$ of the catchment has a slope between $0-8 \%$.

Within the catchment about $71 \%$ is farmland and $18 \%$ is grazing land, while plantation, bush land and settlement areas account for the remaining 11\%. Average rainfall (2013-2015) is $1215 \mathrm{~mm} \mathrm{y}^{-1}$, which falls mainly from June to September, preceded and followed by one month with low and dispersed rains. Average yearly minimum and maximum temperature is $11^{\circ} \mathrm{C}$ and $26^{\circ} \mathrm{C}$, respectively. Dominant soil types are Nitosols (62\%), Eutric Vertisols (30\%), Lithic Leptosols (6\%) and Chromic Cambisols (2\%) (MNREP, 1995).

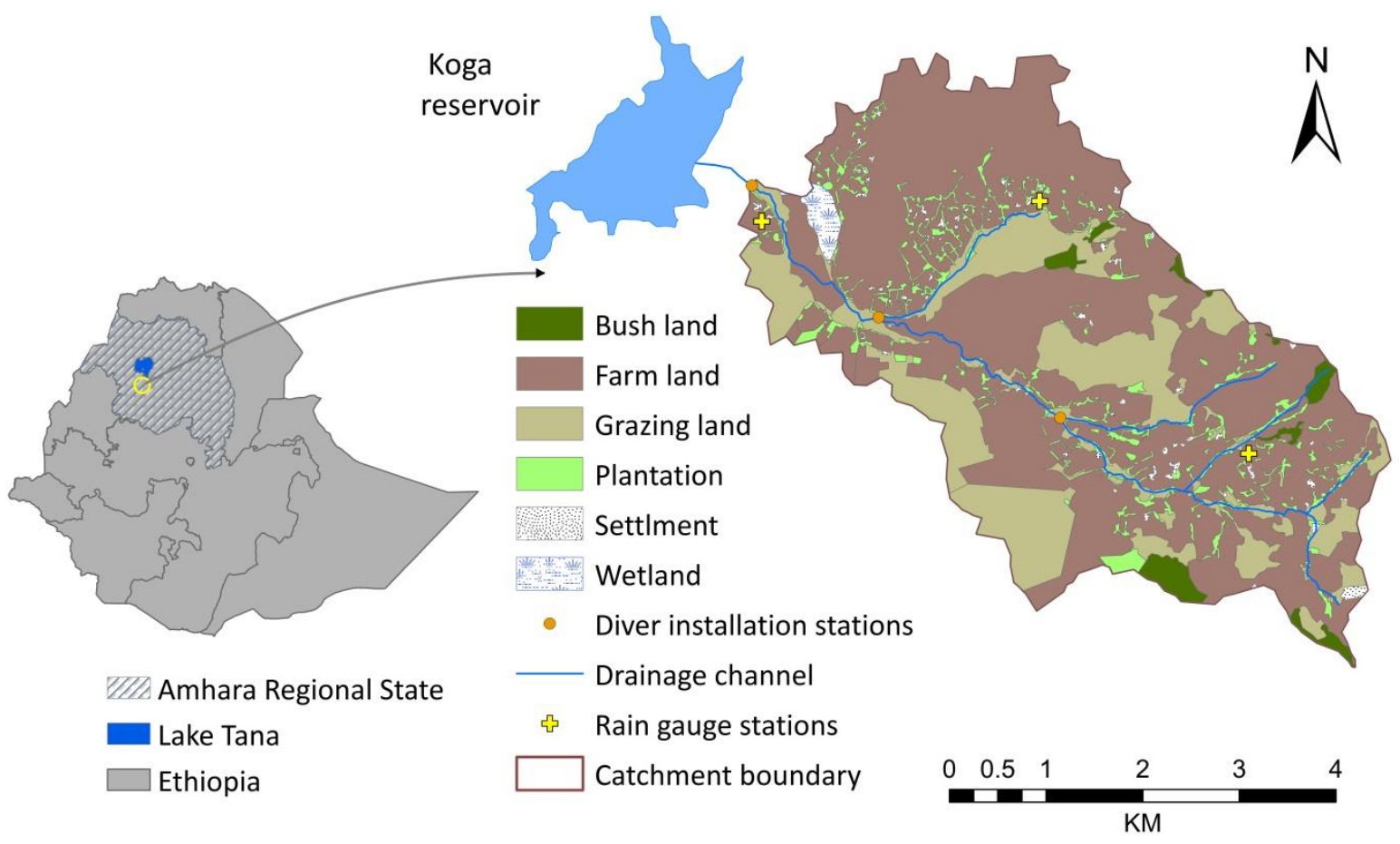

Figure 7.1 Location map of Minizr with land use/cover, rain gauge and diver installation stations

The LAPSUS_D model

In LAPSUS_D, LAPSUS is LAndscape ProcesS modelling at mUlti dimensions and scaleS, and D represents a daily resolution, Figures 7.2 and 7.3). LAPSUS_D is a daily based model that can simulate 
runoff, erosion and sediment yield based on a limited number of input datasets (Keesstra et al., 2014a). It is based on the LAPSUS model (Schoorl et al., 2002; Lesschen et al., 2009; Baartman et al., 2012; Barreto et al., 2013), which was originally created to use yearly timesteps and simulate longterm (decades - millennia) sediment dynamics. LAPSUS-D model can be used at a spatial resolution of a meso-scale catchment $\left(20-200 \mathrm{~km}^{2}\right)$. The spatial data the model requires are: DEM, land use, soil depth, porosity and permeability, while the temporal data the model requires are daily precipitation and evaporation. The model output consists of daily discharge (both water and sediment) values and spatial maps of hydrology, erosion and deposition.

\section{Required input data}

The format in which the model requires the input data varies (Table 7.1). Some data are spatially distributed (e.g., permeability), others vary over time (precipitation, evaporation). The spatially variable data need to be in rasterised maps and temporal data in the form of tabularized series. Moreover, some parameters are variable in both time and space (land use). These data are delivered to the model as spatial maps. Lastly, the elevation changes as a result of the outputs of the model itself.

The DEM of the catchment has a resolution of $30 \mathrm{~m}$ (SRM DEM, 2009). All other maps (soil map and land-use/cover map) were polygon based and were transformed to the same raster size. The soil and texture maps (MNREP, 1995) were used and from it, soil porosity, soil permeability, the maximum infiltration rate and the capacity to hold moisture were estimated. For further confirmation, soil samples at a depth of $0-20 \mathrm{~cm}$ were collected from 20 locations and texture analysis was done in Bahir Dar soil laboratory using the hydrometer method (Sertu \& Bekele, 2000). Soil depth was obtained from MNREP (1995). The land-use map was made from Google Earth images combined with ground truthing in 2014. Daily precipitation was measured at three locations at representative sites (Figure 7.1). The evapotranspiration was presented as a series of evapotranspiration values for each Julian day. Reference evapotranspiration (ETo) was calculated following the equation of Hargreaves (Allen et al., 1998) using the latitude of the location and a general temperature record for a location near the research site.

At the outlet of the Minizr catchment, water height in the river was recorded with a pressure transducer. Daily runoff and sediment discharges were measured from end of May 2013 until September 2015 during the rainy seasons for three years (see chapter 2). For calibration we used runoff collected in 2013. For the validation we used the remainder of the data available (2014-2015). The Nash-Sutcliffe model efficiency factor (MEF) (Nash \& Sutcliffe, 1970) was used to assess the runoff and sediment yield predictive power of the model (Eq. 7.1).

$\mathrm{MEF}=1-\left(\sqrt{\sum(Q m-Q p)^{2}} / \sqrt{\sum(Q m-Q m / n)^{2}}\right)$

Where; $Q m$ is measured discharge, $Q p$ is modelled discharge and $n$ is number of observations

A Digital Elevation Model (SRTM DEM $30 \mathrm{~m}$; 2009) was used to delineate Minizr catchment and to derive its elevation, drainage network and slope characteristics. ArcGIS 10.2.1 software was used for 
mapping and GPS (Garmin 60, $2 \mathrm{~m}$ accuracy) was used to collect ground control points for ground truthing during digitizing land cover/use from Google Map, to indicate locations of rain gauges, diver installation stations and catchment outlets.

Table 7.1 Inputs and outputs of the LAPSUS_D model

\begin{tabular}{lll}
\hline $\begin{array}{l}\text { Input and output data sets } \\
\text { Inputs }\end{array}$ & Spatial resolution & Temporal resolution \\
$\begin{array}{l}\text { Daily precipitation ( measured) } \\
\text { Daily discharge at outlet (measured) }\end{array}$ & 3 sites & Daily \\
DEM & none & $\begin{array}{l}\text { Daily measurement } \\
\text { Not applicable }\end{array}$ \\
Soil information & $30 \mathrm{~m} \times 30 \mathrm{~m}$ & \\
- Porosity (soil map/soil characteristics a derivative) & $30 \mathrm{~m} \times 30 \mathrm{~m}$ & Varies with land use \\
- Permeability (soil map/soil characteristics a & $30 \mathrm{~m} \times 30 \mathrm{~m}$ & Changes with land use \\
$\quad$ derivative) & & \\
$\quad$ Maximum infiltration capacity (soil & $30 \mathrm{~m} \times 30 \mathrm{~m}$ & Changes with land use \\
$\quad$ - Soil depth & & \\
$\begin{array}{l}\text { ETo per Julian day (calculated with Hargreaves) } \\
\text { Land-use map (digitized from Google earth imagery) }\end{array}$ & $30 \mathrm{~m} \times 30 \mathrm{~m}$ & No temporal resolution \\
Outputs & none & daily \\
Maps of soil moisture per day & $30 \mathrm{~m} \times 30 \mathrm{~m}$ & Changes with Julian day \\
$\begin{array}{l}\text { Maps of flow paths } \\
\text { Water discharge at outlet }\end{array}$ & $30 \mathrm{~m} \times 30 \mathrm{~m}$ & Daily \\
Sediment yield at outlet & $30 \mathrm{~m} \times 30 \mathrm{~m}$ & Daily \\
Maps of erosion and deposition in the catchment & None & Daily \\
\end{tabular}

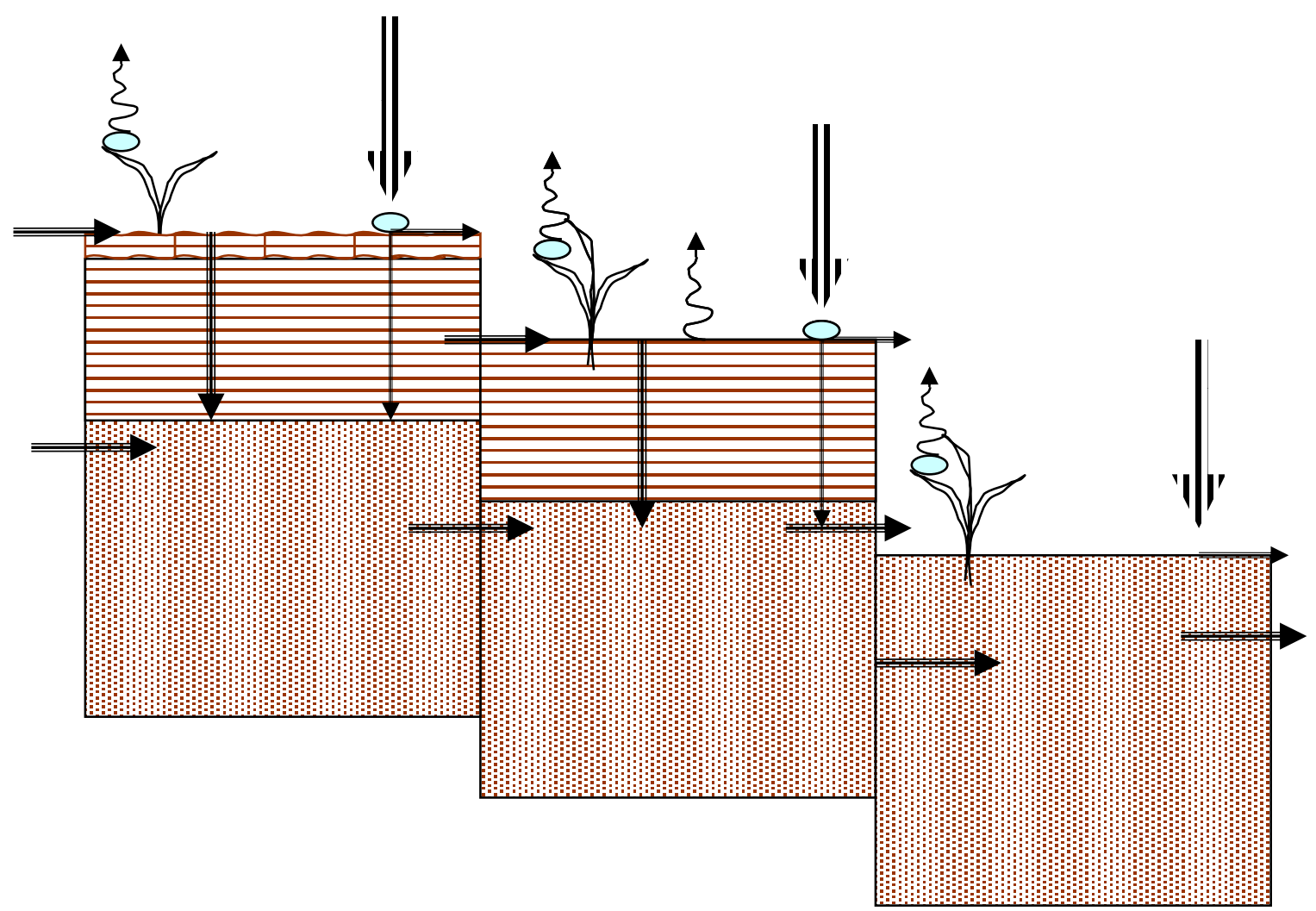

Figure 7.2 Graphical representation of the LAPSUS_D model (Keesstra et al., 2014ab) 


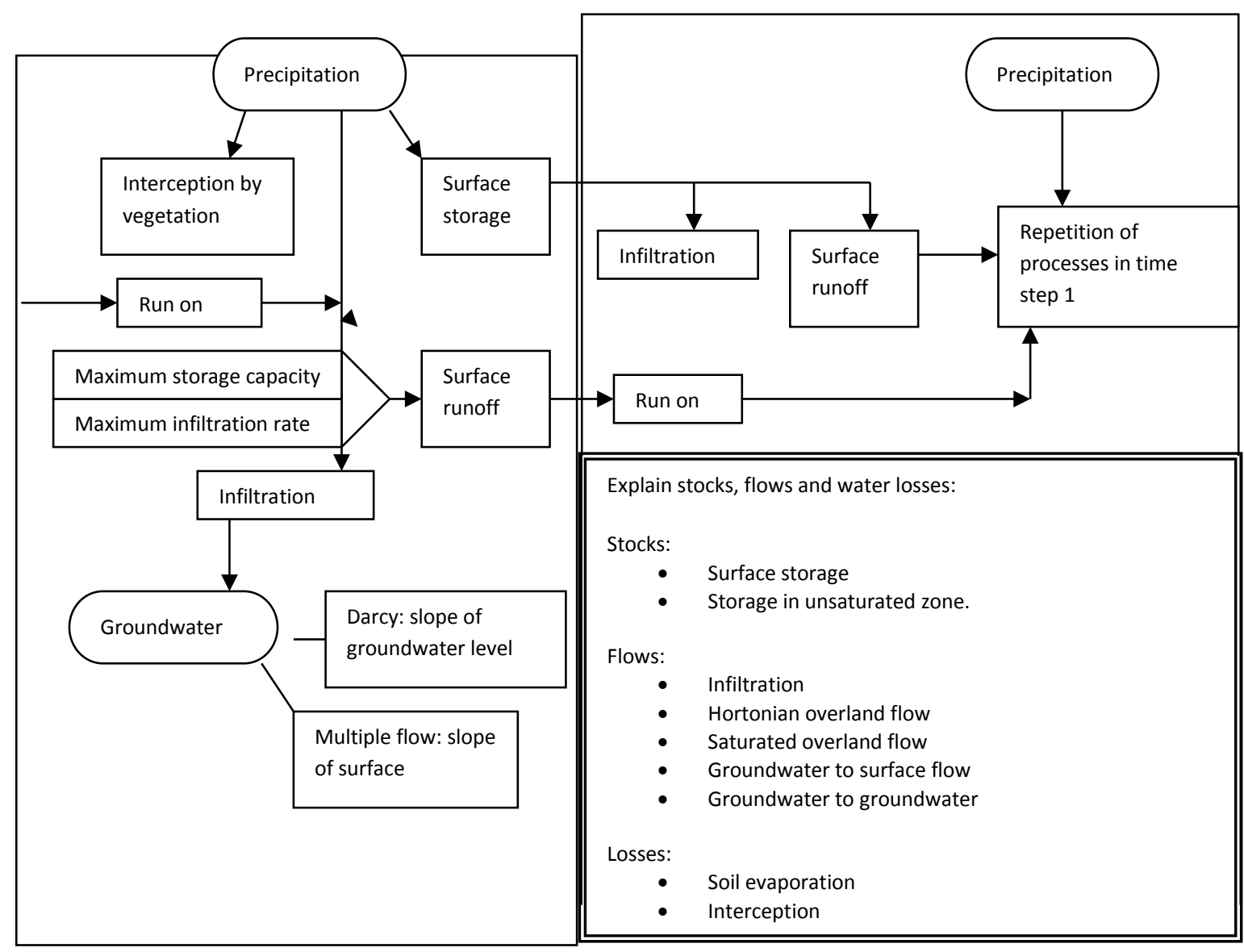

Figure 7.3 Flow chart of the LAPSUS_D model (Keesstra et al., 2014ab)

\subsection{Results}

\section{Calibration and validation}

After preparing the input data sets the LAPSUS_D model was run for calibration and validation. The calibration for daily runoff was promising except a few days after the start of the rainfall (Figure 7.4). The calibration values used were $1.9 ; 1.5 ; 15 ; 0.5$ and 4.3 for porosity, permeability in (vertical permeability; infiltration), permeability through (horizontal permeability), initial storage and evaporation factors, respectively, which resulted in a model efficiency factor (MEF) of 0.322 . Subsequently, the same values were applied to years 2014 and 2015 for validation. Unfortunately, results were not satisfactory for these years (MEF of -0.119 and 0.138 , respectively). According to Nash and Sutcliffe (1970), MEF can range from $-\infty$ to 1 . An efficiency of 1 corresponds to a perfect match of modelled discharge to the observed data and the closer the model efficiency is to 1 , the more accurate the model is. In this case, however, the MEF was 0.322 for the calibration (year 2013) and -0.119 (year 2014) and 0.138 (year 2015) for the validations. 
The most probably reasons of the poor representation of the data is the quality of the DEM. The resolution of $30 \mathrm{~m}$ does not able to represent the small scale variations in the landscape such as the large number of gullies. Furthermore, a large part of the catchment is very flat in terms of topography and therefore small errors in the DEM have a large influence on the representation of the hydrology in the catchment. As a result of this the water was not routed through the catchment as it is in reality. Obviously, since the calibration and validation results of the runoff were not good, the sediment simulation was not feasible to do. we did not go for sediment simulation. Because the model evaluates the rate of sediment transport by calculating the transport capacity of water flowing downslope from one grid cell to another as a function of discharge and slope gradient.

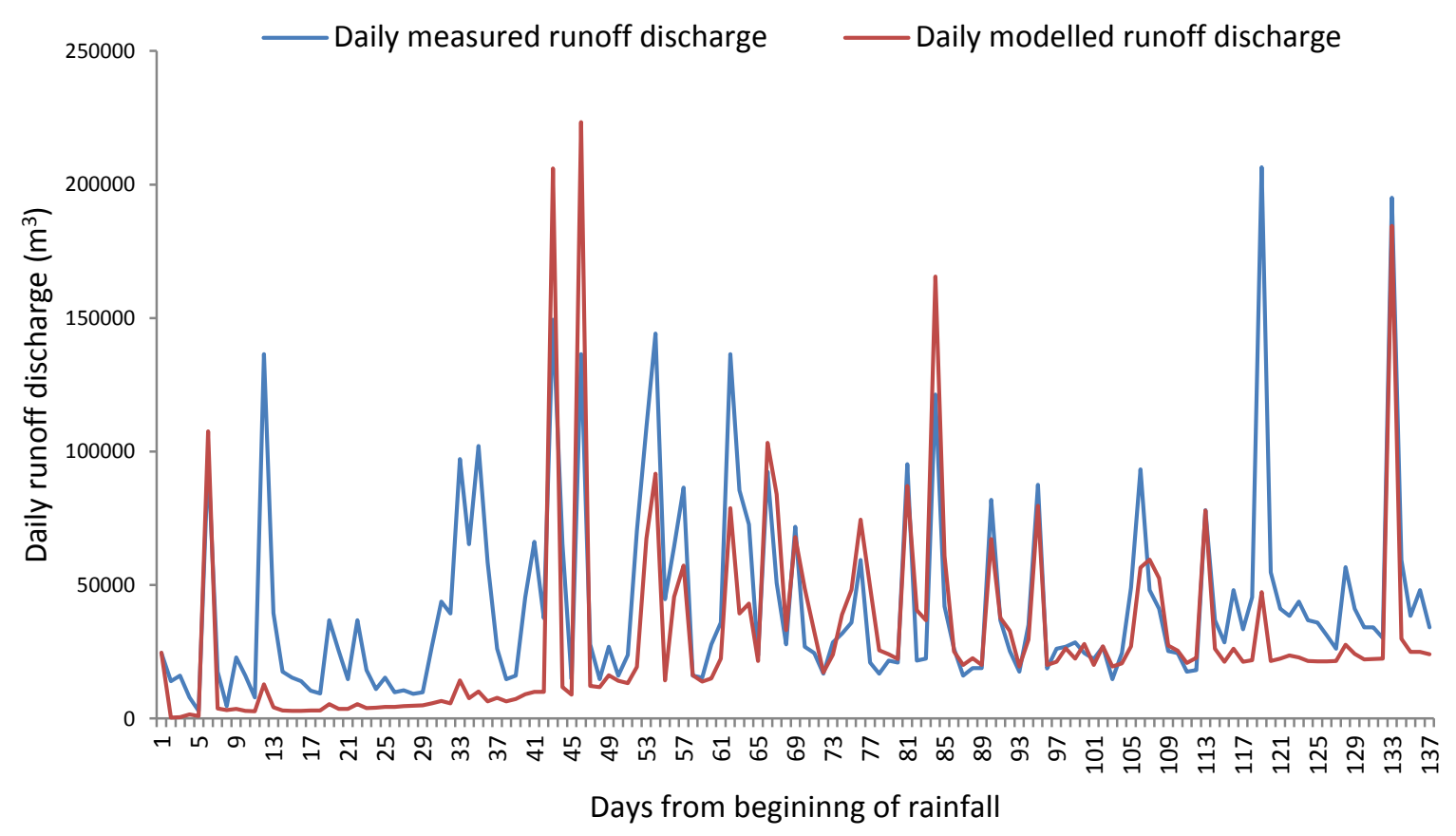

Figure 7.4 Daily measured and modelled runoff discharges during calibration

Because of the fact that the model did not give the desired calibration and validation outputs, the scenario runs could not be executed as planned. The planned scenarios were aimed at identifying best sites for the different ST measures and evaluate their integrated role in trapping sediment at catchment scale. But this objective could not be met. Due to time limitation we did not go further to solve the problem and thus further research is recommended. 


\subsection{Conclusions}

Estimating catchment runoff and sediment yields using model simulation helps to save resources compared with field data measurements. Moreover, models have been increasingly used as valuable alternatives since model simulations can be run to test various implementation scenarios and help to simulate the effectiveness of sediment trapping measures at larger catchment scales, which cannot be feasibly achieved by field experiments. In this study, we tried to adapt the daily based LAPSUS_D model for the northwest highlands of Ethiopia using the three years (2013-2015) runoff yield data collected at the outlet of the Minizr catchment. However, the result was not promising. The most probably reasons of the poor representation of the data is the quality of the DEM. The resolution of $30 \mathrm{~m}$ does not able to represent the small scale variations in the catchment such as the large number of gullies. Furthermore, a large part of the catchment is very flat in terms of topography and therefore small errors in the DEM have a large influence on the representation of the hydrology in the catchment. As a result of this the water was not routed through the catchment as it is in reality. Further study is recommended with a DEM of better resolution. 


\section{Chapter 8}

\section{Synthesis}

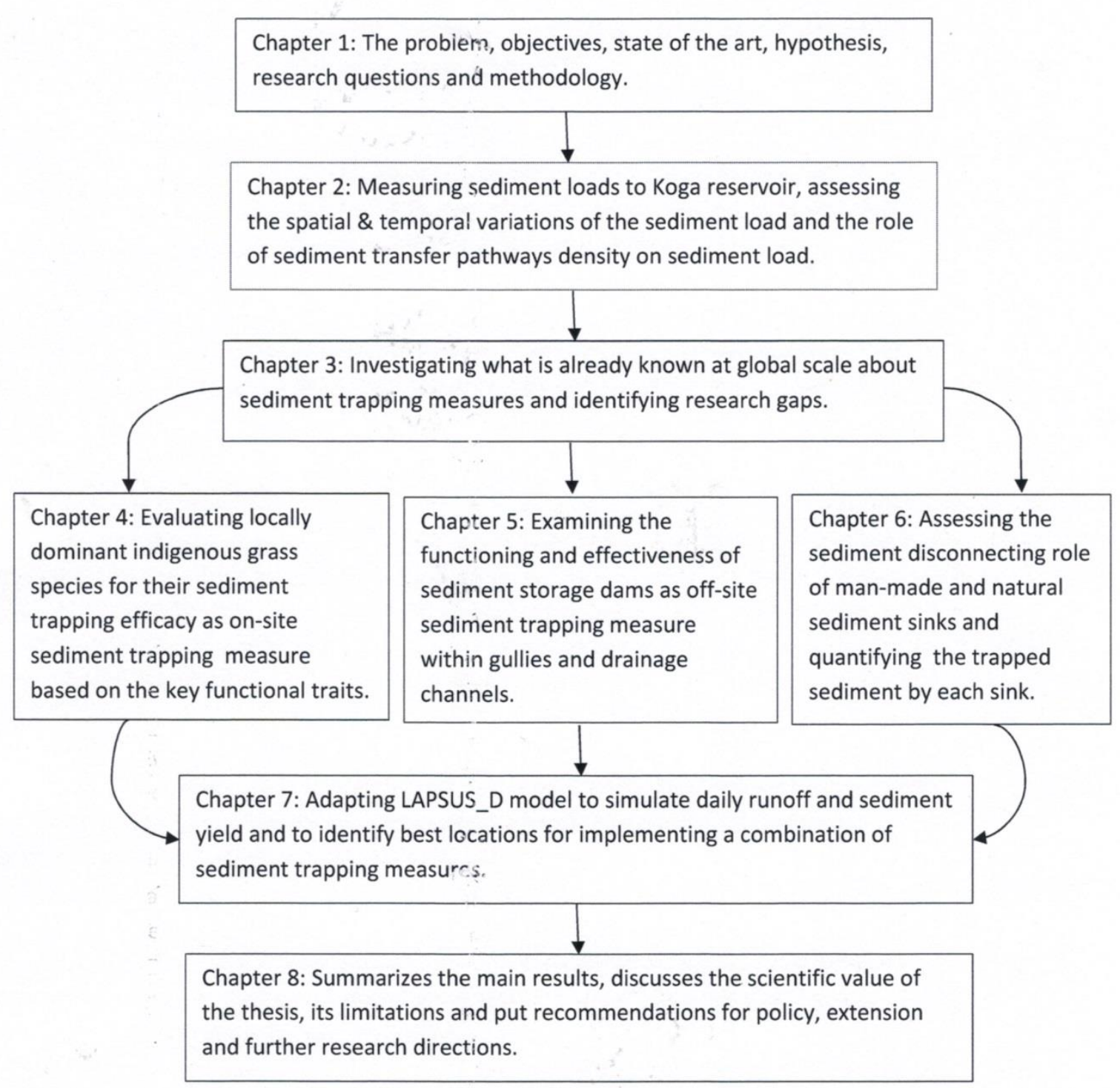




\section{Synthesis}

\subsection{Problem and research themes}

The title of this scientific research is "Sustaining reservoir use through sediment trapping in NW Ethiopia", which focused on Koga reservoir as a case study. In spite of massive investments in sediment trapping measures in the runoff contributing catchment, the life time of Koga reservoir is threatened by sedimentation. Rapid water storage loss due to sedimentation is becoming an important factor undermining the sustainable use of the reservoir.

This thesis covers four main themes of research: (I) Soil erosion within the runoff contributing catchment; (II) Sediment transfer pathways (STPs) serving as a route of runoff and sediment (III) Sedimentation in Koga reservoir; and (IV) Sediment trapping (ST) measures, which help to disconnect the STPs and thus trap sediment within the catchment.

The first theme is soil erosion within the runoff contributing catchment. Soil erosion by water is a priority problem in the upstream runoff contributing catchment of Koga reservoir resulting considerable sediment yield at the outlet of the catchment. Different studies estimated the sediment yield. For example; $3.7 \mathrm{t} \mathrm{ha}^{-1} \mathrm{y}^{-1}$ (MoWR, 2008); $6.2 \mathrm{t} \mathrm{ha}^{-1} \mathrm{y}^{-1}$ (Assefa et al., 2015); $25.6 \mathrm{t} \mathrm{ha}^{-1} \mathrm{y}^{-1}$ (Yeshaneh et al., 2014) and $55 \mathrm{t} \mathrm{ha}^{-1} \mathrm{y}^{-1}$ (Reynolds, 2013).

The second theme is sediment transfer pathways (STPS). STPs serve as a route of runoff and sediment from uplands to lowlands. Although any slope, and any place where water flows is potentially a STP, rivers, gullies and roads are the most important STPs (Poesen et al., 2003; Morgan, 2005; Bracken et al., 2015). An increase in the density of STPs is an indication of increased sediment transport while disconnecting STPs reduces the sediment in transport and increases sedimentability (Fryirs, 2012; Thompson et al., 2016). To study these processes the concept of connectivity was used (Bracken et al., 2015; Parsons et al., 2015; Masselink et al., 2016), which allows studying catchment scale processes in a holistic way. Identifying the STPs within a catchment helps to implement ST measures where they can disconnect the STPs to enhance sedimentation within the catchment (Lloyd et al., 2016).

The third theme is reservoir sedimentation at the outlet of the runoff contributing catchment. Large amounts of sediment are entering Koga reservoir. The estimated amount, however, is different in different studies. For exemple : 48,000 $\mathrm{m}^{3} \mathrm{y}^{-1}$ (MoWR, 2008), 269,000 $\mathrm{m}^{3} \mathrm{y}^{-1}$ (Yeshaneh et al., 2014), $84,800 \mathrm{~m}^{3} \mathrm{y}^{-1}$ (Assefa et al., 2015) and 714,000 $\mathrm{m}^{3} \mathrm{y}^{-1}$ (Reynolds, 2013).

The fourth theme is catchment treatment with ST measures. Treating an upstream catchment is treating a downstream reservoir. To this end, part of the Koga catchment has received a lot of assistance in on-site physical soil conservation measures like fanya juu, soil bund and micro-trenches. For example the Minizr catchment was treated with $144 \mathrm{~km}$ of soil bunds and fanya juu ridges, and with more than 576 micro-trenches. In addition, Minizr catchment contains a wetland and a 
floodplain but we know very little on their function in relation to ST. Therefore, this study was conducted to estimate the sediment loads to Koga reservoir to reduce its uncertainty, to evaluate the functioning and effectiveness of the existing man-made ST measures and natural sediment sinks, and to assess and identify limitations of the existing ST approach for improvement, which help to reduce the sediment load to Koga reservoir.

Our study was conducted in the Minizr catchment which is one of the sources of water for the Koga reservoir. It covers an area of $20 \mathrm{~km}^{2}$ with a slope range of $0-51 \%$ (average of $8 \%$ ), while $>80 \%$ of the catchment has slopes between $0-8 \%$.

\subsection{Research questions and answers}

Our hypothesis was that erosion both on-and off-site can never be stopped sufficiently in NW Ethiopia and will continue becoming an important factor affecting the water storage capacity of reservoirs. Therefore on- and off-site ST measures are needed to reduce the sediment load into valuable reservoirs till a safe level. In other words, not all efforts should focus on on-site soil conservation, but also on the safe routing of sediment-laden flows and on creating sites and conditions where sediment can be trapped, preferably in a cost effective or even profitable way. Hence research questions with respective answers were as follows.

\section{Is the Minizr catchment an important source of sediment for the Koga reservoir? If so, how much is the sediment load? Is there spatial and temporal variation in sediment yield?}

Chapter 2 attempts to quantify the amount of sediment entering Koga reservoir from the Minizr catchment, to identify potential sediment source areas at sub-catchment scale, to assess temporal variation in sediment production on daily, monthly and yearly basis. In addition the role of sediment transfer pathways (STPs) on catchment sediment yield has been assessed.

Results show that on average 43,000 t $\left(21.5 \mathrm{t} \mathrm{ha}^{-1}\right)$ sediment entered Koga reservoir annually from Minizr catchment. The result agrees well with $25.6 \mathrm{t} \mathrm{ha}^{-1} \mathrm{y}^{-1}$ in the upper part of Koga catchment (Yeshaneh et al., 2014) and $24.6 \mathrm{t} \mathrm{ha}^{-1} \mathrm{y}^{-1}$ in the nearby catchment, Anjeni, NW highlands of Ethiopia (Setegn et al., 2010). Spatially, Midre-Genet sub-catchment had the highest density of STPs $(4.7 \mathrm{~km}$ $\left.\mathrm{km}^{-2}\right)$ and gullies, contributed most to the total sediment measured $\left(19,400 \mathrm{t}^{-1}\right)$ followed by Adibera sub-catchment $\left(13,100 \mathrm{t}^{-1}\right)$. Tume-Shafrie sub-catchment with the lowest STPs density and without gullies, contributed the least to the total sediment measured $\left(6,700 \mathrm{t}^{-1}\right)$. Temporally; daily and monthly sediment discharges were highest in July and August. From the total sediment entering Koga reservoir, 63\% was transported in July and August. Drainage channels, gullies and footpaths were found to be the main STPs enhancing sediment connectivity and transport.

The annual sediment entering Koga reservoir from the total runoff contributing catchment was found to be $278,000 \mathrm{~m}^{3}$, which agreed well with $269,000 \mathrm{~m}^{3}$ (Yeshaneh et al., 2014). This indicates that large amounts of sediment are entering Koga reservoir, which considerably compromise its water holding capacity. 
What is the best method or approach to be used while implementing ST measures within a catchment, which helps to reduce sediment in transport to downstream reservoirs?

Chapter 3 investigates what is already known about sediment trapping (ST) measures. It presents an overview of the sediment trapping efficacy (STE) of physical and vegetative ST measures at global scale, reviewing more than 90 scientific journal articles, case studies, government reports, conference proceedings and book chapters. In addition, there are participatory field observations and stakeholders' interviews in the upper part of the Blue Nile basin, Ethiopia.

The STE of physical and vegetative ST measures were evaluated using three implementation approaches: (I) individual approach; (II) combined approach; and (III) integrated approach. Almost all studies evaluated ST measures using the individual approach, which revealed a lower efficacy than the combined approach. Few studies attempted to evaluate the STE of two or more measures using an integrated approach at the catchment scale. This review leads to three promising directions of research put into the next three research questions. An integrated sediment trapping approach was found to be a best approach and is subject to the final research question.

Are the locally dominant indigenous grass species in northwest Ethiopia (Desho, Senbelet, Akirma and Sebez) effective in trapping sediment from agricultural fields? What are the key functional traits, which will play a great role for ST? How much of the inflow sediment trapped by the grass barriers, with what STE?

The sediment trapping efficacy (STE) of many grass species is well known. For example; Lemon grass (72-92\%), Elephant grass (62-84\%), Paspalum (65-88\%) and Sugarcane (56-82\%) in Uganda (Wanyama et al., 2012); Vetiver grass (65\%) in Australia (McKergow et al., 2004); Switch grass (92\%) (Lee et al., 2000) in the USA; Centipede grass (24-73\%) in Japan (Shiono et al., 2007); Black rye (42$69 \%$ ) in China (Pan et al., 2010) and Vetiver (62\%) and Desho (43\%) in the lowland part of Ethiopia (Welle et al., 2006). However, still many grass species that could potentially serve as vegetative barriers have not been studied for their STE, including the locally used grass species in the northwestern Ethiopian highlands, Desho (Pennisetum pedicellatum), Senbelet (Hyparrhenia rufa), Sebez (Pennisetum schimpri) and Akirma (Eleusine floccifolia).

Chapter 4 evaluated the STE of such indigenous grass species and one exotic grass species, Vetiver (Vetiveria zizanioides) at $8 \%$ slope Teff field based on the key functional traits that influence the STE of the grass species. Desho with the highest tiller number and density, and the second highest in root length showed better STE (76\%) than the other grass species, Vetiver (59\%), Senbelet (49\%), Akirma $(36 \%)$ and Sebez $(20 \%)$. The fast lateral spreading growth nature, leading to covering the free space between rows and within rows within a short period of time helps Desho grass to perform best.

The grass barriers trapped large amount of sediment and reduced on-site soil loss between 15 and 53 t ha ${ }^{-1} \mathrm{y}^{-1}$. Desho, Vetiver, Senbelet, Akirma and Sebez reduced 53; 42; 34; 26 and $15 \mathrm{t} \mathrm{ha}^{-1} \mathrm{y}^{-1}$, respectively, compared with the control plot without a grass barrier. This indicates that grass barriers can be used as an effective soil conservation measure in replacing the costly and more maintenance 
demanding physical structures like trenches and ridges, as also noted by (MOARD, 2005), for fields up to $8 \%$ slope. An important advantage of vegetative measures over physical structures is the use of grass as feed. Moreover, Desho and Vetiver grasses are not affected by nor harbour rats unlike the case in physical structures such as stone bunds.

\section{How much sediment can be trapped by sediment storage dams, with what STE? Are they economically feasible for the small-scale farmers' in Ethiopia?}

Since we found that drainage channels and gullies are main sediment transfer pathways (STPs) sediment storage dams (SSDs) are considered an interesting sediment trapping option which we investigated in Chapter 5. Results show that SSD constructed from stone and gabion trapped considerable amount of sediment and they are found to be important off-site ST measures. On average SSDs trapped about 1,584 $t$ of sediment annually with STE ranging from $67-74 \%$. SSDs also played an important role in disconnecting the STPs, refilling deep gully areas with sediment and reducing the channel gradient. Although SSDs trapped such a large amount of sediment inside temporary drainage channels and gullies, they are not affordable for small scale farmers in Ethiopia due to high construction costs. As an alternative mass mobilization to reduce labour cost, project support to buy gabion and implementing the dams in areas with ample construction materials (for example stones) should be considered to minimize the cost.

How much sediment is trapped by the existing physical ST measures, with what STE? How much sediment is trapped by natural sediment sinks, with what STE? Are man-made and natural sediment sinks reducing the sediment load to Koga reservoir?

After three years of intensive data collection and field survey, the sediment trapped behind manmade ST measures such as soil bunds (Erken), fanya Juu (Kab) and micro-trenches, and natural sediment sinks such as a wetland and floodplain were quantified at the Minizr catchment (Chapter 6). Existing man-made and natural sediment sinks played an important role in trapping sediment, with $38 \%\left(26,600 \mathrm{t} \mathrm{y}^{-1}\right)$ of transported sediment being trapped, while $62 \%\left(43,000 \mathrm{t} \mathrm{y}^{-1}\right)$ is exported from the catchment and thus enters the Koga reservoir. About $144 \mathrm{~km}$ soil bunds and fanya juu ridges trapped 7,920 $\mathrm{t}$ annually with an average sedimentation rate of $55 \mathrm{~kg} \mathrm{~m}^{-1} \mathrm{y}^{-1}$ and a STE of $54 \%$, which was within the range of 12.5 to $88.8 \mathrm{~kg} \mathrm{~m}^{-1} \mathrm{y}^{-1}$ (Lecce et al., 2006)). However, our result was much lower compared with Gebremichael et al. (2005), which was $119 \mathrm{~kg} \mathrm{~m}^{-1} \mathrm{y}^{-1}$, in an area with high soil erosion in their catchment.

The 24 ha wetland located near the outlet of the Minizr catchment trapped 8,715 t of sediment annually at an average sedimentation rate of $36 \mathrm{~kg} \mathrm{~m}^{-2} \mathrm{y}^{-1}$ and with a STE of $85 \%$. This result agrees well with the literature. For example, $14-121 \mathrm{~kg} \mathrm{~m}^{-2} \mathrm{y}^{-1}$ (Braskerud, 2001) and STEs of 80\% (Elder \& Goddard, 1996), 71-90\% (Sezerino et al., 2012) and 72-88\% (Line et al., 2008). The 17 ha floodplain trapped 9,970 $\mathrm{t}$ of sediment annually with a STE of $77 \%$ and an average sedimentation rate of $59 \mathrm{~kg}$ $\mathrm{m}^{-2} \mathrm{y}^{-1}$. This result is in line with Brunet and Astin (2008), who found sedimentation rates ranging from 0.02-75 $\mathrm{kg} \mathrm{m}^{-2} \mathrm{y}^{-1}$. Substantial differences were observed between the STE of grassed and ungrassed waterways at $75 \%$ and $21 \%$, respectively. 


\section{Is it possible to use a landscape model (LAPSUS_D) in the northwest Ethiopian highlands to help with integrated sediment trapping at catchment scale by optimizing the use of ST measures?}

Chapter 7 tried to calibrate and validate the daily based LAPSUS_D model for runoff and sediment yield simulation. We used the three years data collected from 2013-2015 (Chapter 2). Data collected in 2013 was used for calibration and data collected in 2014 and 2015 were used for validation. The daily runoff calibration result was promising, however, the two years validation results were not sufficient. Because of the fact that the model did not give the desired calibration and validation outputs, scenario runs for a more integrated ST approach could not be executed as planned. The planned scenarios were aimed at identifying best sites for the different ST measures and evaluate their integrated role in trapping sediment at catchment scale. But this objective could not be met. Due to time limitation we did not go further to solve the problem and thus further research is recommended.

The most probably reasons of the poor reproduction of the observed data is the quality of the DEM. The resolution of $30 \mathrm{~m}$ does not able to represent the small scale variations in the landscape such as the large number of gullies. Furthermore, a large part of the catchment is very flat in terms of topography and therefore small errors in the DEM have a large influence on the representation of the hydrology in the catchment. As a result, water was not routed through the catchment as it is in reality. The model evaluates the rate of sediment transport by calculating the transport capacity of water flowing downslope from one grid cell to another as a function of discharge and slope gradient. Obviously, since the calibration and validation results of the runoff were not good, sediment simulation was not feasible. Thus, further study to further develop this daily based model is recommended.

\subsection{Scientific and societal contributions}

The findings of this study make an important contribution to the scientific community, the society and the final users of the research findings, farmers.

Different studies estimated the sediment loads of Koga reservoir. However, the result showed considerable difference ranging from $48,000 \mathrm{~m}^{3}$ to $714,000 \mathrm{~m}^{3} \mathrm{y}^{-1}$ (3.7 to $55 \mathrm{t} \mathrm{ha}^{-1} \mathrm{y}^{-1}$ ) which creates uncertainty for SWC practitioners, decision makers and researchers. This study tried to solve this uncertainty collecting field data for three years, conducting intensive field survey focusing on the sub-catchment, Minizr, and finding comparable result, which agreed well with literature.

This thesis assessed the sediment trapping efficacy (STE) of physical and vegetative ST measures at global scale, reviewing more than 90 scientific journal articles, case studies, government reports, conference proceedings and book chapters and making participatory field observations and stakeholders' interviews in the upper part of the Blue Nile basin, Ethiopia. This is an important input to experts, researchers, decision and policy makers to have an understanding on the existing situation at global scale. 
Almost all previous studies evaluated the sediment trapping effectiveness of physical ST measures through measuring sediment yield at the outlet of the study catchment and comparing annual differences. This method was unable to provide information of the effectiveness of each individual measure implemented within the catchment rather is shows the collective effectiveness. This thesis evaluated the sediment trapping effectiveness of physical ST measures such as soil bunds and fanya juu ridges involving linear measurement in one direction pertaining to length $\left(\mathrm{kg} \mathrm{m}^{-1} \mathrm{y}^{-1}\right)$; microtrenches measuring the amount of sediment trapped by a single micro-trench $\left(\mathrm{kg} \mathrm{y}^{-1}\right)$. This will help to know the effectiveness as well as the weakness of individual measures for further improvements.

This research is the first to test and scientifically proof the STE of the dominant indigenous grass species (Desho, Senbelet, Akirma and Sebez) in the NW Ethiopian highlands as on-site ST measure giving attention to their key functional traits. As a result best vegetative ST measures have been identified to be used by farmers, which helps them trap sediment within their farmlands and reduce soil loss. This added generic scientific knowledge to researchers working on the influence of grass barriers on ST processes, as well as practitioners dealing with erosion and runoff control on croplands

This study also assessed the STE of sediment storage dams and natural sediment sinks such as a floodplain and wetland (in $\mathrm{kg} \mathrm{m}^{-2} \mathrm{y}^{-1}$ ) to evaluate their effectiveness in trapping sediment in addition to quantifying the amount of sediment trapped by each measure. This helps to know the STEs of the measures, which were not well known before in the Ethiopia conditions.

Integrated catchment management approach (in the sense of integrating sectors, systems, technologies and resources) was started before decades in Ethiopia. Integrated sediment trapping is part of this approach, which focuses on technological integration. However, it does not reduce catchment sediment yield to a safe level. Therefore, this thesis tried to show the limitations of this approach. The existing approach focuses too much on on-site treatments largely disregarding off-site treatments. To trap sediment within the catchment and reduce sediment yield at the outlet of the catchment, both on- and off-site ST measures should be integrated at catchment scale.

In this study, the amount of sediment entering Koga reservoir, spatial (sub-catchment scale) and temporal (daily and monthly) variation in sediment discharge and the role of sediment transfer pathways density in connecting the landscape and enhancing sediment transport were assessed for the Minizr catchment. All of these will help to plan, design and implement appropriate ST measures within the catchment. This will contribute a vital role for SWC practitioners and decision makers.

\subsection{Extension and policy issues}

Reservoir construction requires a large investment. For example, the Ethiopian government invested more than 405 million Ethiopian Birr $(25 \mathrm{ET}=1 €)$ to construct the Koga dam, which is designed to irrigate about 7,000 ha of land and is expected to benefit about 14,000 farmers living downstream of the reservoir. However, sedimentation is undermining its sustainable use. 
Therefore, it is highly advisable to treat the upstream catchment and reduce the sediment load to a safe level. To this end, the government can issue a special policy that supports "Upstream catchment management using an integrated sediment trapping approach before reservoir construction for sustainable reservoir use". This means "catchment treatment before reservoir construction". This will help to use sustainably the large number of reservoirs, which are under construction and planned for construction by the Ethiopian government, including the Grand Ethiopia Renaissance Dam, designed to generate 6,000 MW hydro-electric power investing more than 90 Billion Ethiopia Birr.

The Amhara national Regional State, especially the Bureau of Agriculture (BOA), is working hard on SWC throughout the region including the Minizr catchment, following an integrated catchment management approach. Although successes have been reported, overall catchment scale sediment yield reduction is still low. For example, only $38 \%$ of the transported sediment was trapped and reduced at Minizr catchment and $62 \%$ was leaving the catchment and entering Koga reservoir. This is because the ST approach within the catchment is not enough integrated. Attention was given to onsite treatments largely ignoring the off-site treatments. Therefore, off-site measures should be implemented at the most appropriate spatial locations to further reduce the sediment entering Koga reservoirs (Mekonnen et al., 2014b), which includes: (I) Implementing check dams and sediment storage dams (SSD) inside gullies and temporary drainage channels, because SSDs can trap 3/4 of the incoming sediment with the STE of 67-74 \% (Mekonnen et al., 2015b); (II) Identifying a buffer zone around the reservoir and planting grass (or other vegetative measures) to trap the sediment coming from the surrounding farmlands. According to Mekonnen et al. (2016b) indigenous grass species can trap up to $76 \%$ of the inflowing sediment; (III) Protecting and expanding the already established wetlands around the reservoir because wetlands can trap up to $85 \%$ of the inflowing sediment Mekonnen et al. (2016a); (IV) Establishing a buffer zone and planting trees along the river to reduce riverbank erosion since vegetation causes flow retardation within the channel and on the riverbanks and enhance sedimentation (Keesstra et al., 2012); and (V) Disconnecting major sediment transfer pathways since they enhance sediment connectivity and transport.

Wetlands help to maintain good water quality in rivers, recharge groundwater, stabilise climatic conditions and control sedimentation in lakes and reservoirs. However, they are at risk. For example, at Minizr catchment, agricultural expansion strongly affected the sparsely existing wetland around the Koga reservoir and along river sides. Part of the wetland area is given to the landless youths to cultivate and produce crops. They are trying to convert the wetland into farmland by draining the wetland and ploughing it. This will totally destroy the wetland and its ecosystem in a short period of time. As an alternative, instead of cultivating the wetland area for crop production, the youths could use the grass growing on the wetland for livestock fattening, as a means of income without affecting the wetland. This is a win-win benefit between nature and human beings. Therefore, awareness creation to policy makers, the surrounding farmers and youth associations should be done to conserve, manage and use the wetland sustainably.

There is a promising start on riverside plantation near the Minizr catchment outlet. This should be strengthened and continued to the upstream ends of both temporary and permanent streams/rivers. Similarly, in the outlet part of the catchment farmers are using cut and carry system and reduced free 
grazing, which will serve as a lesson for the farmers living in the upper part of the catchment, especially in the Adibera sub-catchment where serious overgrazing was observed. It would be also important to up-scale these practices to other areas in the region.

\subsection{Challenges and future research recommendations}

This study estimated the amount of sediment entering Koga reservoir; provided the spatial (subcatchment scale) and temporal (daily and monthly) variation of sediment load, assessed the role of sediment transfer pathways density on landscape connectivity and sediment yield and evaluated the sediment trapping efficacy (STE) of existing man-made SWC structures and natural sediment sinks. All of these help to trap sediment within the catchment and reduce sediment loads to Koga reservoir. However, a number of issues remain to be assessed in greater detail, which help to strengthen the findings.

- In this thesis, the STE of the locally dominant grass species was evaluated under $8 \%$ slope farmland, at $1.5 \mathrm{~m}$ strip width and under sheet erosion conditions, hence further study is recommended to evaluate their efficacy at higher slopes (> 8\%), under concentrated flow conditions as well as at different strip widths.

- In this study, only suspended sediment was measured to estimate the sediment load of Koga reservoir. Hence, further study is recommended to estimate the bed load and know its contribution to the sediment load of Koga reservoir.

- In this thesis, the total suspended sediment load was measured at the outlet of the Minizr catchment and its sub-catchments. However, the sediment load share of agricultural lands, gullies, river banks and roads is not evaluated separately, which help to know their specific influence for targeted treatments, thus further study is recommended.

- Spatial variation in sediment production was assessed at sub-catchment scale, however to know specific locations of sediment source areas, cell-based studies are recommended at higher spatial resolution.

- The sediment load of Koga reservoir from its total runoff contributing catchment was estimated from the sediment yield of Minizr catchment. Therefore, either large scale studies of the total catchment or up-scaling from small catchments is recommended as it was believed to provide better estimates.

- A daily resolution LAPSUS_D model was run to simulate runoff and sediment yield and to identify best sites for the different ST measures and evaluate their integrated role in trapping sediment at catchment scale at Minizr catchment. However it does not provide promising results yet. Therefore, further study is highly recommended to further develop this model, run scenarios for optimizing the spatial integration of ST measures. 


\section{References}

Abedini, M., Md Said, M.A., Ahmad, F. 2012. Effectiveness of check dam to control soil erosion in a tropical catchment. Catena 97, 63-70.

Abu-Zreig, M., Rudra, R.P., Lalonde, M.N., Whiteley, H.R., Kaushik, N.K. 2004. Experimental investigation of runoff reduction and sediment removal by vegetated filter strips. Hydrological Processes 18, 20292037.

Adimassu, Z., Mekonnen, K., Yirga, C., Kessler, A. 2014. Effect of soil bunds on runoff, soil and nutrient losses, and crop yield in the central highlands of Ethiopia. Land Degradation and Development 25, 554-564.

Aksoy, H., Kavvas, M.L. 2005. A review of hillslope and watershed scale erosion and sediment transport models. Catena 64, 247-271.

Allen, R.G., Pereira, L.A., Raes, D., Smith, M. 1998. Crop evapotranspiration. FAO Irrigation and Drainage Paper 56. FAO, Rome, 293 pp.

Amare, A. 2005. Study of sediment yield from the Watershed of Angereb reservoir. Master's Thesis, Department of Agricultural Engineering, Alemaya University, Ethiopia.

Amare, T., Zegeye , A., Yitaferu, B., Steenhuis, T., Hurni, H., Zeleke, G. 2014. Combined effect of soil bund with biological soil and water conservation measures in the northwestern Ethiopian highlands. Ecohydrology \& Hydrobiology 14, 192-199.

American Heritage Dictionary, 2011. Houghton Mifflin Harcourt Publishing Company. Fifth Edition. http://www.thefreedictionary.com/wetland.

Amsalu, A., de Graaff, J. 2007. Determinants of adoption and continued use of stone terraces for soil and water conservation in an Ethiopian highland watershed. Ecological Economics 61, 294-302.

Amsalu, A., Stroosnijder, L., de Graaf, J. 2007. Long-term dynamics in land resource use and the driving forces in the Beressa watershed, highlands of Ethiopia. Journal of Environmental Management 83, 448-459.

Anderson, D. M., Macdonald, L. H. 1998. Modelling Road Surface Sediment Production using a Vector Geographic Information System. Earth Surface Processes and Landforms 23, 95-107.

Armstrong, J.L., Mackenzie, D.H. 2002. Sediment yields and turbidity records from small upland subcatchments in the Warragamba Dam catchment, southern New South Wales. Australian Journal of Soil Research 40, 557-579.

Assefa, T.T., Tilahun, S.A., Mihret, D.A., Ayana, E.K., Mahri, M., Schmitter, P., Jha, M.K., Langan, S. 2015. Reservoir sedimentation and hotspot areas in Koga Watershed of the Upper Blue Nile Basin, Ethiopia. TropiLakes 2015. Tropical lakes in a changing environment: water, land, biology, climate and humans. Bahir Dar, Ethiopia.

Ayele, G., Gessess, A., Addisie, M., Tilahun, S., Tebebu, T., Tenessa, D., Langendoen, E., Nicholson, C., Steenhuis, T. 2016. A Biophysical and Economic Assessment of a Community-based Rehabilitated Gully in the Ethiopian Highlands. Land Degradation and Development 27, 270-280.

Baade, J., Franz, S., Reichel, A. 2012. Reservoir siltation and sediment yield in the Kruger National Park, South Africa: A first assessment. Land Degradation \& Development 23, 586-600. 
Baartman, J.E.M., Masselink, R., Keesstra, S.D., Temme, A.J.A.M. 2013. Linking landscape morphological complexity and sediment connectivity. Earth Surface Processes and Landforms 38, 1457-1471.

Baartman, J.E.M., Van Gorp, W., Temme, A.J.A.M., Schoorl, J.M. 2012. Modelling sediment dynamics due to hillslope-river interactions: Incorporating fluvial behaviour in landscape evolution model LAPSUS. Earth Surface Processes and Landforms 37, 923-935.

Barreto, L., Schoorl, J.M., Kok, K., Veldkamp, T., Hass, A. 2013. Modelling potential landscape sediment delivery due to projected soybean expansion: A scenario study of the sub-basin, Cerrado, Maranhão state, Brazil. Journal of Environmental Management 115, 270-277.

Basson, G. 2008. Reservoir Sedimentation - an overview of Global Sedimentation rates, Sediment Yield and Sediment Deposition prediction.

Bationo, A., Hartemink, A., Lungu, O., Naimi, M., Okoth, P., Smaling, E., Thiombiano, L. 2006. African Soils: Their Productivity and Profitability of Fertilizer use. African Fertilizer summit, June 9-13, 2006 Abuja, Nigeria.

Bellin, N., Vanacker, V., van Wesemael, B., Sole-Benet, A., Bakker, M.M. 2011. Natural and anthropogenic controls on soil erosion in the Internal Betic Cordillera (southeast Spain). Catena 87, 190-200.

Berendse, F., van Ruijven, J., Jongejans, E., Keesstra, S.D. 2015. Loss of plant species diversity reduces soil erosion resistance of embankments that are crucial for the safety of human societies in low-lying areas. Ecosystems 18, 881-888.

Bewket, W. 2002. Land cover dynamic since the 1950s in Chemoga watershed, Blue Nile basin, Ethiopia. Mountain Research and Development 22, 263-269.

Bewket, W., Sterk, G. 2003. Assessment of soil erosion in cultivated fields using a survey methodology for rills in the Chemoga watershed, Ethiopia. Agriculture, Ecosystems and Environment 97, 81-93.

Birhanu, A. 2003. Factors influencing the adoption of soil conservation practices in northwestern Ethiopia. Institute of Rural Development. University of Gottingen, Germany.

Blanchard, R.A., Ellison, C.A., Galloway, J.M., Evans, D.A. 2011. Sediment concentrations, loads, and particlesize distributions in the Red River of the North and selected tributaries near Fargo, North Dakota, during the 2010 spring high-flow event. U.S. Geological Survey Scientific Investigations Report 2011-5064 $27 \mathrm{p}$.

Blanco-Canqui, H., Gantzer, C., Anderson, S., Alberts, E., Thompson, A. 2004. Grass barrier and vegetative filter strip effectiveness in reducing runoff, sediment, nitrogen, and phosphorus loss. Soil Science Society of America Journal 68, 1670-1678.

Blanco-Canqui, H., Gantzer, C.J., Anderson, S.H. 2006. Performance of Grass Barriers and Filter Strips under Interrill and Concentrated Flow. Journal of Environmental Quality 35, 1969-1974.

BOA (Bureau of Agriculture). 2015. Agriculture for renaissance. Green development for productivity increment and society benefit. ANRS, BOA, Bahir Dar, Ethiopia, 55 pp.

Borin, M., Vianello, M., Morari, F., Zanin, G. 2005. Effectiveness of buffer strips in removing pollutants in runoff from a cultivated field in North-East Italy. Agriculture Ecosystems \& Environment 105, 101114.

Bosshart, U. 1997. Catchment Discharge and Suspended Sediment Transport as Indicators of Physical Soil and Water Conservation in the Mayketin Catchment, Afdeyu Research Unit. A Case Study in the Northern Highlands of Eritrea SCRP. Research Report, Bern, 39, 137pp.

Bracken, L., Turnbull, L., Wainwright, J., Bogaart, P. 2015. Sediment connectivity: a framework for understanding sediment transfer at multiple scales. Earth Surface Processes Landforms 8, 177-188. 
Bracken, L.J., Croke, J. 2007. The concept of hydrological connectivity and its contribution to understanding runoff-dominated geomorphic systems. Hydrological Processes 21, 1749-1763.

Bracmort, K.S., Engel, B.A., Frankenberger, J.R. 2004. Evaluation of structural best management practices 20 years after installation: Black Creek Watershed, Indiana. Journal of Soil and Water Conservation 59, 191-196.

Braskerud, B.C. 2001. The influence of vegetation on sedimentation and resuspension of soil particles in small constructed wetlands. Journal of Environmental Quality 30, 1447-1457.

Brunet, R.C., Astin, K.B. 2008. A comparison of sediment deposition in two adjacent floodplains of the River Adour in southwest France. Journal of Environmental Management 88, 651-657.

Buendia, C., Vericat, D., Batalla, R.J., Gibbins, C.N. 2016. Temporal dynamics of sediment transport and transient in-channel storage in a highly erodible catchment. Land Degradation and Development 27, 1045-1063.

Burylo, M., Rey, F., Bochet, E., Dutoit, T. 2012. Plant functional traits and species ability for sediment retention during concentrated flow erosion. Plant and Soil 353, 135-144.

Cerdà, A. 1997a. The effect of patchy distribution of Stipa tenacissima L. on runoff and erosion. Journal of Arid Environments 36, 37-51.

Cerdà, A. 1997b. Soil erosion after land abandonment in a semiarid environment of Southeastern Spain. Arid Soil Research and Rehabilitation 11, 163-176.

Cerda, A., Gimenez-Morera, A., Jordan, A., Pereira, P., Novara, A., Keesstra, S., Mataix-Solera, J., RuizSinoga, J. 2015. The Shrubland as soil and water conservation agent in Mediterranean-Type ecosystems. The Sierra Enguera study contribution. In: Dykes, A.P., Mulligan, M., Wainwright, J. (eds) Monitoring and modelling dynamic environments. John Wiley \& Sons, 45-59.

Cerda, A., Morera, A.G., Bodi, M.B. 2009. Soil and water losses from new citrus orchards growing on sloped soils in the western Mediterranean basin. Earth Surface Processes and Landforms 34, 1822-1830.

Chao, B.F., Wu, Y.H., Li, Y.S. 2008. Impact of artificial reservoir water impoundment on global sea level. Science 320, 212-214.

Chiu, Y.J., Borghuis A.M., Lee H.Y., Change K.T., H., C.J. 2007. Estimation of soil erosion in a reservoir watershed using 137cs fallout radionuclide. International Journal of Sediment Research, 304-317.

Coyne, M. S., Gilfillen, R. A., Rhodes, R. W. \& Blevins, R. L. 1995. Soil and fecal coliform trapping by grass filter strips during simulated rain. Journal of Soil and Water Conservation, 50, 405-408.

CSA (Central Statistical Authority). 1999. Agricultural sample survey 1998/99 volume I: Report on area and production for major crops (private peasant holdings, meher season). Statistical Bulletin 200, Addis Ababa, Ethiopia.

Dagnachew, L., Villiers, S.D., Sewalem, T., Dida, M., Masresha, F., Kimani, W., Kassahun, T. 2014. Genetic diversity and echo-geographical distribution of Eleusine species collected from Ethiopia. African crop Science Society Journal 22, 45-58.

Dai, Q., Liu, Z., Shao, H., Yang, Z. 2015. Karst bare slope soil erosion and soil quality: A simulation case study. Solid Earth 6, 985-995.

de Vente, J., Poesen, J., Bazzoffi, P., Van Rompaey, A., Verstraeten, G. 2006. Predicting catchment sediment yield in Mediterranean environments: the importance of sediment sources and connectivity in Italian drainage basins. Earth Surface Processes Landforms 31, 1017-1034.

Deletic, A. 2001. Modelling of water and sediment transport over grassed areas. Journal of Hydrology 248, 168-182. 
Dendy, F., Cooper, C. 1984. Sediment trap efficiency of a small reservoir. Journal of Soil and Water Conservation 39, 278-280.

Dermisis, D., Abaci, O., Papanicolaou, A. N., Wilson, C.G. 2010. Evaluating grassed waterway efficiency in southeastern lowa using WEPP. Soil Use and Management 26, 183-192.

Dillaha, T.A., Reneau, R.B., Mostaghimi, S., Lee, D. 1989. Vegetative filter strips for agricultural nonpoint source pollution control. Transactions of the Asae 32, 513-519.

Douglas, G., Mcivor, I., Manderson, A., Koolaard, J., Todd, M., Braaksma, S., RAJ., G. 2013. Reducing shallow landslide occurrence in pastoral hill country using wide-spaced trees. Land Degradation and Development 24, 103-114.

Easton, Z., Fuka, D., White, E., Collick, A., Ashagre, B.B., McCartney, M., Awulachew, S., Ahmed, A., Steenhuis, T. 2010. A multi basin SWAT model analysis of runoff and sedimentation in the Blue Nile, Ethiopia. Hydrology and Earth System Sciences 14, 1827-1841.

Edem, I.D., Udoinyang, U.C., Ijah, C.J. 2012. Erosion studies under vetiver hedge management in Ibadan, South-Westhern Nigeria. Advances in Applied Science Research 3, 2586-2590.

Elder, J.F., Goddard, G. 1996. Sediment and Nutrient Trapping Efficiency of a Constructed Wetland near Delavan Lake, Wisconsin, 1993-1995, US Geological Survey.

Ellis, T.W., Leguedois, S., Hairsine, P.B., Tongway, D.J. 2006. Capture of overland flow by a tree belt on a pastured hillslope in south-eastern Australia. Australian Journal of Soil Research 44, 117-125.

EMA (Ethiopian Mapping Agency). 1987. Field survey by Ethiopian Mapping Agency. Air photography 1:50 000 scale by SWEDSURVEY. Addia Ababa, Ethiopia.

Engdayehu, G., Fisseha, G., Mekonnen, M., Melesse, M. 2015. Evaluating Technical Standards of Physical Soil and water Conservation practices and their Role in Soil Loss Reduction: The case of Debre Mewi Watershed, Northwest Ethiopia, in: Melesse A.M. and Abtew W. (Eds.), Landscape Dynamics, Soil and Hydrological Processes in Varied Climates. Springer International Publishing, Switzerland, 789-818.

Erkossa, T., Wudneh, A., Desalegn, B., Taye, G. 2015. Linking soil erosion to on-site financial cost: Lessons from watersheds in the Blue Nile basin. Solid Earth 6, 765-774.

Erktan, A., Cecillon, L., Roose, E., Frascaria-Lacoste, N., Rey, F. 2013. Morphological diversity of plant barriers does not increase sediment retention in eroded marly gullies under ecological restoration. Plant and Soil 370, 653-669.

Evrard, O., Vandaele, K., van Wesemael, B., Bielders, C.L. 2008. A grassed waterway and earthen dams to control muddy floods from a cultivated catchment of the Belgian loess belt. Geomorphology 100, 419-428.

FAO (Food and Agricultural Organization). 1986. Ethiopian Highlands Reclamation Study. Final Report, Volume 1 prepared for the Government of Ethiopia by the Food and Agriculture Organization of the United Nations, FAO, Rome.

FAO (Food and Agricultural Organization). 1993. Field measurement of soil erosion and runoff. Natural resource management and environment department. FAO Corporate Document Repository. Rome.

Fiener, P., Auerswald, K. 2003. Effectiveness of grassed waterways in reducing runoff and sediment delivery from agricultural watersheds. Journal of Environmental Quality 32, 927-936.

Fiener, P., Auerswald, K. 2006. Seasonal variation of grassed waterway effectiveness in reducing runoff and sediment delivery from agricultural watersheds in temperate Europe. Soil \& Tillage Research 87,48 58. 
Fiener, P., Auerswald, K., Weigand, S. 2005. Managing erosion and water quality in agricultural watersheds by small detention ponds. Agriculture Ecosystems \& Environment 110, 132-142.

Fisseha, G., Gebrekidan, H., Kibret, K., Bedadi, B., Yitaferu, B. 2011. Participatory Development of Soil Conservation Measures at the Debre-Mewi Watershed in the Upper Catchment of the Blue Nile Basin, Northwest Ethiopia. Journal of Biodiversity and Environmental Sciences 1, 199-213.

Frankl, A., Poesen, J., Haile, M., Deckers, J., Nyssen, J. 2013. Quantifying long-term changes in gully networks and volumes in dryland environments: The case of Northern Ethiopia. Geomorphology 201, 254-263.

Fryirs, K. 2012. (Dis)Connectivity in catchment sediment cascades: a fresh look at the sediment delivery problem. Earth Surface Processes and Landforms 38, 30-46.

Gao, P. 2008. Understanding watershed suspended sediment transport. Progress in Physical Geography 32, 243-263.

Gao, P., Josefson, M. 2012. Event-based suspended sediment dynamics in a central New York watershed. Geomorphology 139-140, 425-437.

Garbrecht, J.D., Starks, P.J. 2009. Watershed sediment yield reduction through soil conservation in a WestCentral Oklahoma watershed. Ecohydrology 2, 313-320.

Gebremichael, D., Nyssen, J., Poesen, J., Deckers, J., Haile, M., Govers, G., Moeyersons, J. 2005. Effectiveness of stone bunds in controlling soil erosion on cropland in the Tigray Highlands, northern Ethiopia. Soil Use and Management 21, 287-297.

Goudie, A.S. 2004. Encyclopedia of Geomorphology 1. Routledge, New York. ISBN 0-415-32737-7.

Grove, A.O., Rackham, O. 2001. The Nature of Mediterranean Europe, An Ecological History. Yale University Press.

GTZ/IFSP (Integrated Food Security Programme). 2004. Integrated food security programme. Bureau of Agriculture: Bahir Dar, Ethiopia.

Hagmann, J. 1996. Mechanical soil conservation with contour ridges: Cure for, or cause of, rill erosion? Land Degradation and Development 7, 145-160.

Haile, G.W., Fetene, M. 2012. Assessment of soil erosion hazard in kilie catchment, East Shoa, Ethiopia. Land Degradation and Development 23, 293-306.

Haileslassie, A., Priess, J., Veldkamp, E., Teketay, D., Lesschen, J.P. 2005. Assessment of soil nutrient depletion and its spatial variability on smallholders' mixed farming systems in Ethiopia using partial versus full nutrient balances. Agriculture, Ecosystems and Environment 108, 1-16.

Halide, H., Ridd, P.V., Peterson, E.L., Foster, D. 2003. Assessing sediment removal capacity of vegetated and non-vegetated settling ponds in prawn farms. Aquacultural Engineering 27, 295-314.

Haregeweyn, N., Poesen, J., Nyssen, J., De Wit, J., Haile, M., Govers, G., Deckers, S. 2006. Reservoirs in Tigray (Northern Ethiopia): Characteristics and sediment deposition problems. Land Degradation and Development 17, 211-230.

Haregeweyn, N., Poesen, J., Nyssen, J., Govers, G., Verstraeten, G., de Vente, J., Deckers, J., Moeyersons, J., Haile, M. 2008. Sediment yield variability in Northern Ethiopia: A quantitative analysis of its controlling factors. Catena 75, 65-76.

Haregeweyn, N., Poesen, J., Verstraeten, G., Govers, G., de Vente, J., Nyssen, J., Deckers, J., Moeyersons, J. 2013. Assessing the performance of a spatially distributed soil erosion and sediment delivery model (WATEM/SEDEM) in northern Ethiopia. Land Degradation and Development 24, 188-204. 
Haregeweyn, N., Yohannes, F. 2003. Testing and Evaluation of Agricultural Nonpoint Source Pollution Model (AGNPS) on Agucho Catchment, Western Harerghie. Agriculture, ecosystems \& environment 99, 201-212

Herweg, K., Ludi, E. 1999. The performance of selected soil and water conservation measures - case studies from Ethiopia and Eritrea. Catena 36, 99-114.

Herweg, K., Stillhardt, B. 1999. The variability of soil erosion in the highlands of Ethiopia and Eritrea. SCRP Research Report, CDE, University of Bern, Switzerland, $81 \mathrm{pp}$.

Higgitt, D. L., Lu, X.X. 2001. Sediment delivery to the three gorges: Catchment controls. Geomorphology 41, 143-156.

Hooke, J. 2003. Coarse sediment connectivity in river channel systems: A conceptual framework and methodology. Geomorphology 56, 79-94.

Hrissanthou, V., Delimani, P., Xeidakis, G. 2010. Estimate of sediment inflow into Vistonis Lake, Greece. . International Journal of Sediment Research, 161-174.

Hughes, A. O., Prosser, P.I. 2012. Gully erosion prediction across a large region: Murray-Darling Basin, Australia. Soil Research 50, 267-277.

Hupp, C.R., Demas, C.R., Kroes, D.E., Day, R.H., Doyle, T.W. 2008. Recent sedimentation patterns within the central Atchafalaya Basin, Louisiana. Wetlands 28, 125-140.

Hurni, H. 1986. Soil conservation in Ethiopia. Community Forests and Soil Conservation Department, Ministry of Agriculture, Addis Ababa.

Hurni, H. 1987. Erosion - productivity - conservation systems in Ethiopia. Soil Conservation and Productivity. Proceedings of the 4th Int. Soil Conservation Conference, Maracay, Venezuela. 654-674 pp.

Hurni, H. 1993. Land degradation, famine and land resources. Scenarios in Ethiopia. In: Pimental D. (ed.), Soil erosion and conservation. Cambridge University Press, Cambridge, UK, 27-62.

Hurni, H. 2000. Assessing Sustainable Land Management. Agriculture, Ecosystems and Environment 81, 8392.

ICOLD (International Commission of Large Dams). 2007. World Register of Dams, Re-look to conventional techniques for trapping efficiency estimation of a reservoir. International Journal of Sediment Research 23, 76-84.

Iqbal, Z., Cui, G.B., Zhang, L.Q. 2003. Sedimentation retention basin utilization for best management practice. Journal of Environmental Sciences-China 15, 662-668.

ISSS (International Society of Soil Science). 1996. Terminology for Soil Erosion and Conservation. 1-313.

Kadlec, R.H., Roy, S.B., Munson, R.K., Charlton, S., Brownlie, W. 2010. Water quality performance of treatment wetlands in the Imperial Valley, California. Ecological Engineering 36, 1093-1107.

Kagabo, D.M., Stroosnijder, L., Visser, S.M., Moore, D. 2013. Soil erosion, soil fertility and crop yield on slow-forming terraces in the highlands of Buberuka, Rwanda. Soil \& Tillage Research 128, 23-29.

Kebede, W. 2012. Watershed Manual: An Option to Sustain dam and Reservoir Functions in Ethiopia. Journal of Environmental Sciences and Technology 5, 262-273.

Keesstra, S., Pereira, P., Novara, A., Brevik, E., Azorin-Molina, C., Parras-Alcántara, L., Jordán, A., Cerdà, A. 2016. Effects of soil management techniques on soil water erosion in apricot orchards. Science of the Total Environment 357-366.

Keesstra, S.D. 2007. Impact of natural reforestation on floodplain sedimentation in the Dragonja basin, SW Slovenia. Earth Surface Processes and Landforms 32, 49-65. 
Keesstra, S.D., Bruijnzeel, L.A., van Huissteden, J. 2009a. Meso-scale catchment sediment budgets: combining field surveys and modeling in the Dragonja catchment, southwest Slovenia. Earth Surface Processes and Landforms 34, 1547-1561.

Keesstra, S.D., Kondrlova, E., Czajka, A., Seeger, M., Maroulis, J. 2012. Assessing riparian zone impacts on water and sediment movement: A new approach. Netherland Journal for Geosciences 91, 245-256.

Keesstra, S.D., Temme , A.J.A.M., Schoorl, J.M., Visser, S.M. 2014a. Evaluating the hydrological component of the new catchment-scale sediment delivery model LAPSUS-D. Geomorphology http://dx.doi.org/10.1016/j.geomorph.2013.1004.1021.

Keesstra, S.D., Temme, A.J.A.M., Schoorl, J.M., Visser, S.M. 2014b. A new, simple model for temporal and spatial sediment fluxes in meso-scale catchments: LAPSUS-D: the hydrological functioning. Geomorphology 212, 97-107.

Keesstra, S.D., van Dam, O., Verstraeten, G., van Huissteden, J. 2009b. Changing sediment generation due to natural reforestation in the Dragonja catchment, SW Slovenia. Catena 78, 60-71.

Knight, K.W., Schultz, R.C., Mabry, C.M., Isenhart, T.M. 2010. Ability of remnant riparian forests, with and without grass filters, to buffer concentrated surface runoff. Journal of the American Water Resources Association 46, 311-322.

Kosmas, C., Danalatos, N.G., Gerontidis, S. 2000. The effect of land parameters on vegetation performance and degree of erosion under Mediterranean conditions. Catena 40, 3-17.

Kruger, H., Berhanu, F., Yohannes, G., Kefene, K. 1996. Creating an inventory of indigenous soil and water conservation measures in Ethiopia. In Sustaining the Soil: Indigenous Soil and Water Conservation in Africa, Reij C, Scoones I, Toulmin C (eds). Earth Scan Publications London, 170-180.

Lakel, W.A., Aust, W.M., Bolding, M.C., Dolloff, C.A., Keyser, P. 2010. Sediment Trapping by Streamside Management Zones of Various Widths after Forest Harvest and Site Preparation. Forest Science 56, 541-551.

Lal, R. 2001. Soil degradation by erosion. Land Degrad and Development 12, 519-539.

Lambrechts, T., François, S., Lutts, S., Muñoz-Carpena, R., Bielders, C.L. 2014. Impact of plant growth and morphology and of sediment concentration on sediment retention efficiency of vegetative filter strips: Flume experiments and VFSMOD modeling. Journal of Hydrology 511, 800-810.

Lanckriet, S., Derudder, B., Naudts, J., Bauer, H., Deckers, J., Haile, M., Nyssen, J. 2015. A Political Ecology Perspective of Land Degradation in the North Ethiopian Highlands. Land Degradation and Development 26, 521-530.

Lasanta, A., Cerdà, A. 2005. Long-term erosional responses after fire in the Central Spanish Pyrenees: 2. Solute release. Catena 60, 80-101. .

Lecce, S.A., Gares, P.A., Pease, P.P. 2006. Drainage ditches as sediment sinks on the coastal plain of north Carolina. Physical Geography 27, 447-463.

Lee, K.H., Isenhart, T.M., Schultz, R.C. 2003. Sediment and nutrient removal in an established multi-species riparian buffer. Journal of Soil and Water Conservation 58, 1-8.

Lee, K.H., Isenhart, T.M., Schultz, R.C., Mickelson, S.K. 2000. Multispecies riparian buffers trap sediment and nutrients during rainfall simulations. Journal of Environmental Quality 29, 1200-1205.

Leguedois, S., Ellis, T.W., Hairsine, P.B., Tongway, D.J. 2008. Sediment trapping by a tree belt: processes and consequences for sediment delivery. Hydrological Processes 22, 3523-3534. 
Leh, M., Bajwa, S., Chaubey, I. 2013. Impact of land use change on erosion risk: and integrated remote sensing geographic information system and modeling methodology. Land Degradation \& Development 24, 409-421.

Lesschen, J.P., Cammeraat, L.H., Nieman, T. 2008. Erosion and terrace failure due to agricultural land abandonment in a semi-arid environment. Earth Surface Processes Landforms 33, 1574-1584

Lesschen, J.P., Schoorl, J.M., Cammeraat, L.H. 2009. Modelling runoff and erosion for a semi-arid catchment using a multi-scale approach based on hydrological connectivity. Geomorphology 109, 174-183.

Line, D.E., Jennings, G.D., Shaffer, R.M., Calabria, J., Hunt, W.F. 2008. Evaluating the effectiveness of two storm water wetlands in north Carolina. ASABE 51, 521-528.

Liu, Z., Yao, Z., Huang, H., Wu, S., Liu, G. 2012. Land use and climate changes and their impacts on runoff in the Yarlung Zangbo river basin, China. Land Degradation and Development, 203-215.

Lloyd, C.E.M., Freer, J.E., Johnes, P.J., Collins, A.L. 2016. Using hysteresis analysis of high-resolution water quality monitoring data, including uncertainty, to infer controls on nutrient and sediment transfer in catchments. Science of the Total Environment 543, 388-404.

Marchamalo, M., Hooke, J.M., Sandercock, P.J. 2016. Flow and Sediment Connectivity in Semi-arid Landscapes in SE Spain: Patterns and Controls. Land Degradation and Development 27, 1032-1044.

Markle, J. 2009. Efficacy of settlement ponds for reducing pyrethroid runoff in almond orchards. Modesto, CA: Almond Board of California. Final research report 2008-2009. 1-24 pp.

Markusic, M.S., McLaughlin, R.A. 2008. Effects of design changes on sediment retention basin efficiency. In: International Erosion Control Association - 39th Annual Conference and Expo of the International Erosion Control Association 2008 - Environmental Connection 2008: Drive Your Future, 222-231 pp.

Masselink, R.J.H., Keesstra, S.D., Temme, A.J.A.M., Seeger, M., Giménez, R., Casalí, J. 2016. Modelling Discharge and Sediment Yield at Catchment Scale Using Connectivity Components. Land Degradation and Development 27, 933-945.

McCaleb, M.M., McLaughlin, R.A. 2008. Sediment trapping by five different sediment detention devices on conservation sites. Transactions of the Asabe 51, 1613-1621.

McDowell, R.W., Srinivasan, M.S. 2009. Identifying critical source areas for water quality: 2. Validating the approach for phosphorous and sediment losses in grazed headwater catchments. Journal of Hydrology 379, 68-80.

McGraw-Hill. 2003. Dictionary of Engineering. McGraw-Hill companies, Ins.

McGregor, S., Cook, M. 2006. An analysis of rates of sedimentation loading for selected tributaries to the Bear Creek floodway, Alabama and Mississippi 2005-2006, 19 pp.

McKenzie, N., Coughlan, K.J., Cresswell, H. 2002. Soil Physical Measurement and Interpretation For Land Evaluation. CSIRO Publishing: Collingwood, Victoria.

McKergow, L.A., Prosser, I.P., Grayson, R.B., Heiner, D. 2004. Performance of grass and rainforest riparian buffers in the wet tropics, Far North Queensland. Water quality. Australian Journal of Soil Research 42, 485-498.

McKergow, L.A., Weaver, D.M., Prosser, I.P., Grayson, R.B., Reed, A.E.G. 2003. Before and after riparian management: sediment and nutrient exports from a small agricultural catchment, Western Australia. Journal of Hydrology 270, 253-272.

Mekonen, K., Tesfahunegn, G.B. 2011. Impact assessment of soil and water conservation measures at Medego watershed in Tigray, northern Ethiopia. International Journal of Science and Technology 5 , 312-330. 
Mekonnen, M., Keesstra, S.D, Stroosnijder, L., Ritsema, C.J, Baartman, J.E.M. 2015a. Evaluating indigenous grass species as on-site sediment trapping measures, northwest Ethiopian highlands. International Conference on TROPILAKES2015, Tropical lakes in a changing environment. Bahir Dar, Ethiopia, 83-83 pp.

Mekonnen, M., Keesstra, S.D., Baartman, J.E.M., Ritsema, C.J. 2014a. Sediment storage dam: A structural gully erosion control and sediment trapping measure, Northwestern Ethiopia. EGU2014 Geophysical Research Abstracts 16, 114, Austria, Vienna.

Mekonnen, M., Keesstra, S.D., Baartman, J.E.M., Ritsema, C.J., Melesse, A.M. 2015b. Evaluating sediment storage dams: structural off-site sediment trapping measures in northwest Ethiopia. Cuaderno de Investigacion Geografica 41, 7-22.

Mekonnen, M., Keesstra, S.D., Baartman, J.E.M., Stroosnijder, L., Maroulis, J. 2014b. Soil Conservation Through Sediment Trapping: A review. Land Degradation and Development 26, 544-556.

Mekonnen, M., Keesstra, S.D., Baartman, J.E.M., Stroosnijder, L., Maroulis, J. 2016a. Reducing sediment connectivity through man-made and natural sediment sinks in Minizr catchment, northwest Ethiopia. Accepted, Land Degrad and Development Journal.

Mekonnen, M., Keesstra, S.D., Stroosnijder, L., Ritsema, C.J., Baartman, J.E.M. 2016b. Sediment trapping with indigenous grass species showing differences in plant traits in northwest Ethiopia. Accepted, CATENA.

Mekonnen, M., Keesstraa, S.D, Baartmana, J.E.M., Stroosnijder, L. 2016c. Assessing the integrated sediment trapping role of man-made and natural sediment sinks, Minizr catchment, Ethiopia, European Geoscience Union General Assembly 2016, 17-22 April, 2016, Austria, Vienna.

Mekonnen, M. \& Melesse, A. M. 2011. Soil Erosion Mapping and Hotspot area identification using GIS and Remote Sensing in Northwest Ethiopian Highlands, Near lake Tana. Nile River Basin; hydrology, climate \& water use, Springer, 207-224.

Mekonnen, M., Melesse, A.M., Keesstra, S.D. 2015c. Spatial Runoff Estimation and Mapping of Potential Water Harvesting Sites: A GIS and Remote Sensing perspective, northwest Ethiopia, in: Melesse A.M. and Abtew W. (Eds.), Landscape Dynamics, Soils and Hydrological Processes in Varied Climate, Springer Geography, 565-584.

MERET (Managing Environmental Resources to Enable Transition). 2008. MERET NEWS: A quarterly newsletter published by the Ministry of Agriculture and Rural Development, MERET, Project coordination office, Bahir Dar, Ethiopia. Report No 5, 9-10 pp.

Meyer, L.D., Dabney, S.M., Harmon, W.C. 1995. Sediment - trapping effectiveness of stiff-grass hedges Transactions of the Asae 38, 809-815.

MNREP (Ministry of Natural Resource and Environmental protection, water Resource Development Authority). 1995. Feasibility study of the Birr and Koga Irrigation project, Koga catchment and irrigation studies. Koga catchment soil map. Annex K. Acres International Limited Company. Ethiopia.

MOA (Ministry of Agriculture). 2001. Soil and water conservation manual/guideline for Ethiopia. Ministry of Agriculture, natural resources management and regulatory department, Addis Ababa, Ethiopia, 272 pp.

MOARD (Ministry of Agriculture and Rural development). 2005. Community Based Participatory Watershed Development guideline part 1. Addis Ababa, Ethiopia.

MOARD (Ministry of Agriculture and Rural development).2010. Sustainable land management technologies and approaches in Ethiopia. Natural resources management sector, Addis Ababa, Ethiopia. 
Montakhab, A., Yusuf, B. 2011. Removing sediment transport in open channel with submerged aquatic vegetation: Laboratory study. International Journal of Physical Sciences 6, 6775-6780.

Morgan, R.P.C. 2005. Soil erosion and conservation, 3rd edn. National Soil Resource Institute, Cranfield University, Blackwell, London.

MOWR (Ministry of water resource). 2008. Koga Irrigation Scheme (KIS) Manual, Operation and Maintenance (O\&M). Part A, general procedures. Volume II. Addis Ababa, Ethiopia.

Nash, J.E., Sutcliffe, J.V. 1970. River flow forecasting through conceptual models part I - A discussion of principles. Journal of Hydrology 10, 282-290.

NBDC (Nile Basin development Challenge). 2013. Desho grass (pennisetum pedicellatum) for livestock feed, grazing land and soil and water management on small scale farms, (In: Ecocrop. 2010. Database FAO).

Newham, L.T.H., Letcher, R.A., Jakeman, A.J., Kobayashi, T. 2004. A framework for integrated hydrologic, sediment and nutrient export modelling for catchment-scale management. Environmental Modelling and Software 19, 1029-1038.

Newson, M.D., Large, A.R.G. 2006. 'Natural' rivers, 'hydromorphological quality' and river restoration: A challenging new agenda for applied fluvial geomorphology. Earth Surface Processes and Landforms 31, 1606-1624.

Novara, A., Gristina, L., Guaitoli, F., Santoro, A., Cerdà, A. 2013. Managing soil nitrate with cover crops and buffer strips in Sicilian vineyards. Solid Earth 4, 255-262.

Novara, A., Keesstra, S., Cerdà, A., Pereira, P., Gristina, L. 2016. Understanding the role of soil erosion on co2-c loss using $13 \mathrm{c}$ isotopic signatures in abandoned Mediterranean agricultural land. Science of the Total Environment 550, 330-336.

Nyssen, J., Clymans, W., Poesen, J., Vandecasteele, I., De Baets, S., Haregeweyn, N., Naudts, J., Hadera, A., Moeyersons, J., Haile, M. 2009a. How soil conservation affects the catchment sediment budget-a comprehensive study in the north Ethiopian highlands. Earth Surface Processes and Landforms 34, 1216-1233.

Nyssen, J., Descheemaeker, K., Haregeweyn., N., Haile., M., Deckers, J., Poesen, J. 2007a. Lessons learnt from 10 years research on SWC in Tigray.Tigray Livelihood Papers No.7.Zala-Daget Project, Mekelle University, K.U.Leuven, Tigray BOARD, ISBN 978-90-8826-027-8, 53.

Nyssen, J., Frankl, A., Zenebe, A., Deckers, J., Poesen, J. 2015. Land Management in the Northern Ethiopian Highlands: Local and Global Perspectives; Past, Present and Future. Land Degradation and Development 26, 759-764.

Nyssen, J., Haregeweyn, N., Descheemaeker, K., Gebremichael, D., Vancampenhout, K., Poesen, J., Haile, M., Moeyersons, J., Buytaert, W., Naudts, J., Deckers, S., Govers, G. 2006. Comment on 'Modeling the effect of soil and water conservation practices in Tigray, Ethiopia'. Agriculture, ecosystems \& environment 106, 407-411.

Nyssen, J., Poesen, J., Haile, M., Moeyersons, J., Deckers, J., Hurni, H. 2009b. Effects of land use and land cover on sheet and rill erosion rates in the Tigray highlands, Ethiopia. Zeitschrift Fur Geomorphologie 53, 171-197.

Nyssen, J., Poesen, J., Moeyersons, J., Deckers, J., Haile, M., Lang, A. 2004. Human impact on the environment in the Ethiopian and Eritrean highlands - a state of the art. Earth-Science Reviews 64, 273-320. 
Nyssen, J., Poesen, J., Moeyersons, j., Mitiku, H., Deckers, J. 2008. Dynamics of soil erosion rates and controlling factors in the Northern Ethiopian Highlands - towards a sediment budget. Earth Surface Processes Landforms 33, 695-711.

Nyssen J., Poesen J., Gebremichael D., Vancampenhout K., D'aes M., Yihdego G., Govers G., Leirs H., Moeyersons J., Naudts J., Haregeweyn N., Haile M., Deckers J. 2007b. Interdisciplinary on-site evaluation of stone bunds to control soil erosion on cropland in Northern Ethiopia. Soil \& Tillage Research 94, 151-163.

Ochoa, P., Fries, A., Mejía, D., Burneo, J., Ruíz-Sinoga, J., Cerdà, A. 2016. Effects of climate, land cover and topography on soil erosion risk in a semiarid basin of the Andes. Catena 140, 31-42.

Ohare, M.T., Mountford, J.O., Maroto, J., Gunn, L.D. M. 2016. Plant Traits Relevant to Geomorphology and Hydrological Interactions. River Research and Applications 32, 179-189.

Oshunsanya, S. 2013. Spacing effects of vetiver grass hedgerows on soil accumulation and yields of maizecassava intercropping system in Southwest Nigeria. Catena 104, 120-126.

Otto, J., Schrott, L., Jaboyedoff, M., Dikau, R. 2009. Quantifying sediment storage in a high alpine valley (Turtmanntal, Switzerland). Earth Surface Processes and Landforms, 34, 1726-1742.

Pan, C., Ma, L., Shangguan, Z., Ding, A. 2011. Determining the sediment trapping capacity of grass filter strips. Journal of Hydrology 405, 209-216.

Pan, C.Z., Ma, L., Shangguan, Z.P. 2010. Effectiveness of grass strips in trapping suspended sediments from runoff. Earth Surf Process and Landforms 35, 1006-1013.

Parsons, A.J., Bracken L., Peoppl , R., Wainwright J., Keesstra, S.D. 2015. Editorial: Introduction to special issue on connectivity in water and sediment dynamics. In press in Earth Surf Process and Landforms.

Pearce, R.A., Trlica M.J., Leininger W.C., Smith J.L., Frasier G.W. 1997. Efficiency of grass buffer strips and vegetation height on sediment filtration in laboratory rainfall simulation. Journal of Environ Quality 26, 139-144.

Peng, J., Chen, S.L., Dong, P. 2010. Temporal variation of sediment load in the Yellow River basin, China, and its impacts on the lower reaches and the river delta. Catena 83, 135-147.

Pereira, P., Gimeinez-Morera, A., Novara, A., Keesstra, S., Jordán, A., Masto, R.E., Brevik, E., Azorin-Molina, C., Cerdà, A. 2015. The impact of road and railway embankments on runoff and soil erosion in eastern Spain. Hydrol. Earth Syst. Sci. 12, 12947-12985.

Poeppl, R.E., Keiler, M., Von Elverfeldt, K., Zweimueller, I., Glade, T. 2012. The influence of riparian vegetation cover on diffuse lateral sediment connectivity and biogeomorphic processes in a mediumsized agricultural catchment, Austria. Physical Geography 94, 511-529.

Poesen, J., Nachtergaele, J., Verstraeten, G., Valentin, C. 2003. Gully erosion and environmental change: importance and research needs. Catena 50, 91- 133.

Prosdocimi, M., Jordán, A., Tarolli, P., Keesstra, S., Novara, A., Cerda A. 2106. The immediate effectiveness of barley straw mulch in reducing soil erodibility and surface runoff generation in Mediterranean vineyards. . Science of the Total Environment 547, 323-330.

Rachman, A., Anderson, S.H., Alberts, E.E., Thompson, A.L., Gantzer, C.J. 2008. Predicting runoff and sediment yield from a stiff-stemmed grass hedge system for a small watershed. Transactions of the Asabe 51, 425-432.

Ramos-Scharrón, C.E., MacDonald, L.H. 2007. Measurement and prediction of natural and anthropogenic sediment sources, St. John, U.S. Virgin Islands. Catena 71, 250-266.

Ramos Scharrón, C.E. 2010. Sediment production from unpaved roads in a sub-tropical dry setting Southwestern Puerto Rico. Catena 82, 146-158. 
Ran, D.C., Luo, Q.H., Zhou, Z.H., Wang, G.Q., Zhang, X.H. 2008. Sediment retention by check dams in the Hekouzhen-Longmen Section of the Yellow River. International Journal of Sediment Research 23, 159-166.

Reubens, B., Poesen, J., Danjon, F., Geudens, G., Muys, B. 2007. The role of fine and coarse roots in shallow slope stability and soil erosion control with a focus on root system architecture: a review. TreesStruct. Funct 21, 385-402.

Reynolds, B. 2013. Variability and change in Koga reservoir volume, Blue Nile, Ethiopia. Uppsala University, Department of Earth Sciences, Uppsala, Sweden.

Riihimaki, C. 2011. Methodology to Predict Fine Sediment Load Reductions as a Result of Floodplain Inundation in Lake Tahoe Streams. Prepared for the USDA Forest Service Pacific Southwest Research Station. Final Technical Report. Upper Truckee River, California. 44 pp.

Rijkee, P., Keesstra, S.D., Mekonnen, M. 2015. Low-land Gully Formation in the Amhara Region, Ethiopia. Geophysical Research Abstracts. Vol. 17, EGU2015-15827.

Ritsema, C.J. 2003. Introduction: soil erosion and participatory land use planning on the Loess Plateau in China. Catena 54, 1-5.

Robinson, C.A., Ghaffarzadeh, M., Cruse, R.M. 1996. Vegetative filter strip effects on sediment concentration in cropland runoff. Journal of Soil and Water Conservation 51, 227-230.

Rodrigues, S., Silva, T. 2012. Dam construction and loss of geodiversity in the Araguari river basin, Brazil. . Land Degradation and Development 23, 419-426.

Romero-Diaz, A., Marin-Sanleandro, P., Ortiz-Silla, R. 2012. Loss of soil fertility estimated from sediment trapped in check dams. South-eastern Spain. Catena 99, 42-53.

Schoonover, J.E., Williard, K.W.J., Zaczek, J.J., Mangun, J.C., Carver, A.D. 2006. Agricultural sediment reduction by giant cane and forest riparian buffers. Water Air and Soil Pollution 169, 303-315.

Schoorl, J., Veldkamp, A., Bouma, J. 2002. Modeling water and soil redistribution in a dynamic landscape context. Soil Science Society of America Journal 66, 1610-1619.

Schwilch, G., Liniger, H.P., Hurni, H. 2013. Sustainable land management (SLM) practices in drylands: How do they address desertification threats? Environmental management 54, 983-1004.

Seeger, M., Errea, M.P., Begueria, S., Arnáez, J., Martí, C., García-Ruiz, J.M. 2004. Catchment soil moisture and rainfall characteristics as determinant factors for discharge/suspended sediment hysteretic loops in a small headwater catchment in the Spanish Pyrenees. Journal of Hydrology, 299-311.

Sertu, S., Bekele, T. 2000. Procedures for soil and plant analysis. National soil research center. Ethiopian Agricultural Research Organization. National fertilizer sector project, Addis Ababa, Ethiopia.

Setegn, S.G., Dargahi, B., Srinivasan, R., Melesse, A.M. 2010. Modelling of sediment yield from Anjeni gauged watershed, Ethiopia using SWAT Model. Journal of the American Water Resources Association 46, 514-526.

Seutloali, K., Beckedahl, H. 2015. Understanding the factors influencing rill erosion on road cuts in the south eastern region of South Africa. Solid Earth 6, 633-641.

Sezerino, P.H., Bento, A.P., Decezaro, S.T., Carissimi, E., Philippi, L.S. 2012. Constructed wetlands and sand filter applied as onsite post-treatment of anaerobic effluent. Water Practice \& Technology, doi:10.2166/wpt.2012.2047.

Shiono, T., Yamamoto, N., Haraguchi, N., Yoshinaga, A. 2007. Performance of grass strips for sediment control in Okinawa. Jarq-Japan Agricultural Research Quarterly 41, 291-297. 
Skerman, P.J., Riveros., F. 1990. Tropical Grasses. FAO Publications. Available: http://www.fao.org/ag/AGP/AGPC/doc/Gbase/Data/Pf000259.htm (Accessed: Dec. 2015).

Slattery, M.C., Gares, P.A., Philippi, L.S. 2002. Slope-channel linkage and sediment delivery on north Carolina coastal plain cropland. Earth Surface Processes Landforms 27, 1377-1387.

Smith, B.P.G., Naden, P.S., Leeks, G.J.L., Wass, P.D. 2003. The influence of storm events on fine sediment transport, erosion and deposition within a reach of the River Swale, Yorkshire, UK. The Sciences of the Total Environment, 451-474.

Sougnez, N., van Wesemael, B., Vanacker, V. 2011. Low erosion rates measured for steep, sparsely vegetated catchments in southeast Spain. Catena 84, 1-11.

Spaan, W.P., Sikking, A.F.S., Hoogmoed, W.B. 2005. Vegetation barrier and tillage effects on runoff and sediment in an alley crop system on a Luvisol in Burkina Faso. Soil \& Tillage Research 83, 194-203.

Sparovek, G., Beatriz Lima Ranieri, S., Gassner, A., Clerice De Maria, I., Schnug, E., Ferreira Dos Santos, R., Joubert, A. 2002. A conceptual framework for the definition of the optimal width of riparian forests. Agriculture, Ecosystems and Environment 90, 169-175.

Stanchi, S., Falsone, G., Bonifacio, E. 2015. Soil aggregation, erodibility, and erosion rates in mountain soils (NW Alps, Italy). Solid Earth 6, 403-414.

Stefanidis, P., Stefanidis, S. 2012. Reservoir sedimentation and mitigation measures: Lakes \& Reservoirs. Research \& Management 17, 113-117.

Steiner, K., Drechsel, P. 1998. Experiences with participatory on-farm research on erosion control in southern Rwanda. In Adoption driver and constraints of resource conservation technologies in subSaharan Africa, Drechsel P, Olaleye A, Adeoti A, Thiombiano L, Barry B, Vohland B (eds). IBSRAM Proceedings 19: 205-214.

Stroosnijder, L. 2009. Modifying land management in order to improve efficiency of rainwater use in the African highlands. Soil and Tillage Research 103, 247-256.

Stroosnijder, L. 2012. Myths in Land Degeradation and Development. Wageningen: [s.n.]. Farewell address upon retirement. 2012-05-03 40.

Sukristiyonubowo, Gabriels, D., Verloo, M. 2010. Sediment trapping by terraced paddy field on slopping agricultural land. Indonesian Journal of Agricultural Science 11, 57-64.

Syvitski, J., Milliman, J. 2007. Geology, geography, and humans battle for dominance over the delivery of fluvial sediment to the coastal ocean. Journal of Geology 115, 1-19.

Tamene, L., Park, S., Dikau, R., Vlek, P. 2006a. Reservoir siltation in the semi-arid highlands of northern Ethiopia: sediment yield-catchment area relationship and a semi-quantitative approach for predicting sediment yield. Earth Surface Processes and Landforms 31, 1364-1383.

Tamene, L., Park, S.J., Dikau, R., Vlek, P.L.G. 2006b. Analysis of factors determining sediment yield variability in the highlands of northern Ethiopia. Geomorphology 76, 76-91.

Tebebu, T.Y., Abiy, A.Z., Zegeye, A.D., Dahlke, H.E., Easton, Z.M., Tilahun, S.A., Collick, A.S., Kidnau, S., Moges, S., Dadgari, F., Steenhuis, T.S. 2010. Surface and subsurface flow effect on permanent gully formation and upland erosion near Lake Tana in the northern highlands of Ethiopia. Hydrology and Earth System Sciences 14, 2207-2217.

Tesfaye, M., Bravo-Oviedo, A., Bravo, F., Kidane, B., Bekele, K., Sertse, D. 2015. Selection of Tree Species and Soil Management for Simultaneous Fuelwood Production and Soil Rehabilitation in the Ethiopian Central Highlands. Land Degradation and Development 26, 665-679. 
Thomaz, E.L., Luiz, J.C. 2012. Soil loss, soil degradation and rehabilitation in a degraded land area in Guarapuava (Brazil). Land Degradation \& Development 23, 72-81.

Thompson, C.J., Fryirs, K., Croke, J. 2016. The Disconnected Sediment Conveyor Belt: Patterns of Longitudinal and Lateral Erosion and Deposition During a Catastrophic Flood in the Lockyer Valley, South East Queensland, Australia. River Research and Applications 32, 540-551.

Tomer, M.D., Moorman, T.B., Kovar, J.L., James, D.E., Burkart, M.R. 2007. Spatial patterns of sediment and phosphorus in a riparian buffer in western lowa. Soil and Water Conservation 62, 329-338.

Truong, P.N.V., Loch, R. 2004. Vetiver system for erosion and sediment control. ISCO 2004 - 13th International Soil Conservation Organisation Conference, 2-4, Brisbane.

Van Rompaey, A.J.J., Verstraeten, G., Van Oost, K., Govers, G., Poesen, J. 2001. Modelling mean annual sediment yield using a distributed approach. Earth Surface Processes and Landforms 26, 1221-1236.

Vanoni, V.A. 1975. Sedimentation Engineering. ASCE Manuals and Reports on Engineering Practices. No 54. ASCE.

Verstraeten, G., Poesen, J. 2000. Estimating trap efficiency of small reservoirs and ponds: methods and implications for the assessment of sediment yield. Progress in Physical Geography 24, 219-251.

Verstraeten, G., Poesen, J. 2001a. Factors controlling sediment yield from small intensively cultivated catchments in a temperate humid climate. Geomorphology 40, 123-144.

Verstraeten, G., Poesen, J. 2001b. Modelling the long-term sediment trap efficiency of small ponds. Hydrological Processes 15, 2797-2819.

Verstraeten, G., Poesen, J. 2002. Regional scale variability in sediment and nutrient delivery from small agricultural watersheds. Journal of Environmental Quality 31, 870-879.

Verstraeten, G., Poesen, J., de Vente, J.D., Koninckx, X. 2003. Sediment yield variability in Spain: a quantitative and semi-qualitative analysis using reservoir sedimentation rates. Geomorphology 50, 327-348.

Verstraeten, G., Poesen, J., Gillijns, K., Govers, G. 2006. The use of riparian vegetated filter strips to reduce river sediment loads: an overestimated control measure? Hydrological Processes 20, 4259-4267.

Vorosmarty, C.J., Meybeck, M., Fekete, B., Sharma, K., Green, P., Syvitski, J.P.M. 2003. Anthropogenic sediment retention: major global impact from registered river impoundments. Global and Planetary Change 39, 169-190.

Wainwright, J., Parsons, A.J., Michaelides, K., Powell, D.M., Brazier, R.E. 2003. Linking short and long term soil erosion modelling. In: Long Term Hillslope and Fluvial System Modelling. Concepts and Case Studies from the Rhine River Catchment. Springer-Verlag (Bonn), Germany.

Walling, D.E. 2006. Human impact on land-ocean sediment transfer by the world's rivers. Geomorphology 79, $192-216$.

Wang, G.D., Wang, M., Yuan, Y.X., Lu, X.G., Jiang, M. 2014. Effects of sediment load on the seed bank and vegetation of Calamagrostis angustifolia wetland community in the National Natural Wetland Reserve of Lake Xingkai, China. Ecological Engineering 63, 27-33.

Wang, Y., Fu, B., Chen, L., Lü, Y., Gao, Y. 2011. Check dam in the loess plateau of China: Engineering for environmental services and food security. Environmental Science and Technology 45, 10298-10299.

Wanyama, J., Herremans, K., Maetens, W., Isabirye, M., Kahimba, F., Kimaro, D., Poesen, J., Deckers, J. 2012. Effectiveness of tropical grass species as sediment filters in the riparian zone of Lake Victoria. Soil Use and Management 28, 409-418. 
Ward, J.M., Jackson, C.R. 2004. Sediment trapping within forestry streamside management zones: Georgia Piedmont, USA. Journal of the American Water Resources Association 40, 1421-1431.

Wasson, R.J., Caitcheon, G., Murray, A.S., McCulloch, M., Quade, J. 2002. Sourcing sediment using multiple tracers in the catchment of Lake Argyle, north western Australia. Environmental management 29, 634-646.

WBISPP (Woody Biomass Inventory and Strategic Planning Project). 2002. Manual for Woody Biomass Inventory and Strategic Planning Project, Ministry of Agriculture, Addis Ababa, Ethiopia.

WCD (World Commission on Dams). 2000. Dams and Development. A new framework for decision-making. Earth scan publications Ltd, London, 356.

Welle, S., Chantawarangul, K., Nontananandh, S., Jantawat, S. 2006. Effectiveness of grass strips as barriers against runoff and soil loss in Jijiga area, northern part of Somalia region, Ethiopia. Kasetsart Journal: Natural Science 40, 549-558.

White, P., Butcher, D., Labadz, J. 1997. Reservoir sedimentation and catchment sediment yield in the Strines catchment, UK. Physics and Chemistry of the Earth 22, 321-328.

Yeshaneh, E., Eder, A., Blöschl, G. 2014. Temporal variation of suspended sediment transport in the Koga catchment, North Western Ethiopia and environmental implications. Hydrol. Process 28, 5972-5984.

Yuan, Y.P., Bingner, R.L., Locke, M.A. 2009. A Review of effectiveness of vegetative buffers on sediment trapping in agricultural areas. Ecohydrology 2, 321-336.

Zegeye, A.D., Steenhuis, T.S., Blake, R.W., Kidnau, S., Collick, A.S., Dadgari, F. 2010. Assessment of soil erosion processes and farmer perception of land conservation in Debre Mewi watershed near lake tana, Ethiopia. Ecohydrology and Hydrobiology 10, 297-306.

Zeleke, G. 2000. Landscape dynamics and soil erosion process modeling in the North-Western Ethiopian Highlands. African Studies Series A 16, Geographica Bernensia Berne, Switzerland.

Zema, D.A., Bingner, R.L., Denisi, P., Govers, G., Licciardello, F., Zimbone, S.M. 2012. Evaluation of runoff, peak flow and sediment yield for events simulated by the AnnAGNPS model in a belgian agricultural watershed. Land Degradation \& Development 23, 205-215.

Zhang, G.H., LIU, G.B., WANG, G.L. 2010a. Effects of Caragana Korshinskii Kom. cover on runoff, sediment yield and nitrogen loss. International Journal of Sediment Research 25, 245-257.

Zhang, S.H., Liu, S.X., Mo, X.G., Shu, C., Zheng, C.L., Hou, B. 2010b. Impacts of precipitation variation and soil and water conservation measures on runoff and sediment yield in the Wuding River Basin, middle reaches of the Yellow River. Journal of Beijing Forestry University 32, 161-168.

Ziadat, F., Taimeh, A. 2013. Effect of rainfall intensity, slope and land use and antecedent soil moisture on soil erosion in an arid environment. Land Degradation \& Development 24, 582-590. 
Summary 


\section{Summary}

Rainfed agriculture can increase agricultural production and improve food self-sufficiency when supplemented with irrigated agriculture. The Ethiopian government is following this strategy and constructed many reservoirs and still a large number of reservoirs are under construction. Koga reservoir is one of the largest reservoirs in northwest Ethiopia and is a key project for the Ethiopian government. However, rapid water storage loss due to sedimentation is becoming an important factor undermining its sustainable use. This is because of serious soil erosion both on-site and offsite, and lack of an integrated sediment trapping (ST) approach within the water contributing catchments.

To tackle the problem, the Ethiopian government is working hard following a catchment based ST approach. Various soil and water conservation measures have been implemented at large spatial scales in the Amhara region by the Bureau of Agriculture and international and national nongovernmental organizations. For instance, over $144 \mathrm{~km}$ of soil/stone bunds and fanya juu ridges, and $>576$ micro-trenches were constructed within the $20 \mathrm{~km}^{2}$ Minizr catchment in NW Ethiopia. In addition, existing natural sediment sinks such as wetlands and floodplains occur over large areas, and are supplementing man-made structures in trapping sediment.

In spite of massive investments in ST measures, catchment sediment yield at the outlet of Minizr catchment is still large. The sediment trapping efficacy (STE), which is a means to assess the effectiveness of ST measures, is not well known for most of the ST measures. Therefore, there is a need to assess the functioning and effectiveness of the existing ST measures and to design a more effective approach to reduce sediment yield at the outlets of catchments and manage reservoir sedimentation to a safe level.

Chapter $\mathbf{2}$ attempts to quantify the amount of sediment entering Koga reservoir, to assess spatial and temporal variation in sediment production and to identify sediment transfer pathways (STPs), which enhance sediment connectivity and facilitate sediment transport. Insight herein could help to design improved ST strategies and reduce the siltation problem of the reservoir. From Minizr catchment annually 43,000 t of sediment is entering Koga reservoir with a sediment yield of $21.5 \mathrm{t} \mathrm{ha}^{-1} \mathrm{y}^{-1}$. Using this sediment yield, the annual sediment entering Koga reservoir from the whole runoff contributing catchment was found to be $350,000 \mathrm{t}\left(278,000 \mathrm{~m}^{3}\right)$. This reduces the uncertainty of sediment loads to Koga reservoir estimated by different studies showing large variations that ranged from 48,000 $700,000 \mathrm{~m}^{3}\left(3-55 \mathrm{tha}^{-1} \mathrm{y}^{-1}\right)$. Out of the total sediment entering Koga reservoir, 63\% was transported in July and August. This was due to high gully and river bank erosions in July and August. STPs density shows a good relation $\left(R^{2}=0.88\right)$ with catchment sediment production.

Chapter 3 investigates what is already known about sediment trapping measures. It presents an overview on the sediment trapping efficacy (STE) of physical and vegetative sediment trapping (ST) measures at global scale, reviewing more than 90 scientific journal articles, case studies, government reports, conference proceedings and book chapters. In addition, there are participatory field 
observations and stakeholders' interviews in the upper part of the Blue Nile basin, Ethiopia. Three ST approaches individual, combined and integrated were identified. Of these, the integrated approach at the catchment scale, is believed to be the most effective in helping to increase the STE of ST measures and thereby reducing sediment load at the outlet of the catchment.

This review leads to three promising directions of research. Since we can expect effective sediment trapping using grass strips we evaluated a number of species in a field trial described in Chapter 4. Since we found that drainage channels, gullies and footpaths are main sediment transfer pathways, sediment dams are also considered an interesting option which we investigated in Chapter 5. Finally it is worthwhile to know the trapping efficiency of existing man-made soil and water conservation structures in the catchment such as soil bunds, fanya juu and micro-trenches (Chapter 6 ). The same holds for the existing natural sediment sinks like the floodplain, the wetland and different waterways.

Chapter 4 evaluated the STE of four locally dominant indigenous grass species, Desho (Pennisetum pedicellatum), Senbelet (Hyparrhenia rufa), Sebez (Pennisetum schimpri) and Akirma (Eleusine floccifolia) and one exotic but well adapted and locally used grass species, Vetiver (Vetiveria zizanioides) at Debre Mewi catchment, in northwest Ethiopia, based on the key functional traits that influence their STE. These grass species reduced soil loss up to $53 \mathrm{t} \mathrm{ha}^{-1} \mathrm{y}^{-1}$ with the STE ranging from 20-76\%. STE showed a good correlation with key functional traits such as tiller density, number of tillers and root length. Desho with the highest tiller number and density, highest root length (depth) and fast lateral spreading growth pattern showed better STE (76\%) compared with other grass species. This indicates that such grass barriers can be used as a soil conservation measure replacing the more costly and more maintenance demanding physical structures like trenches and ridges up to $8 \%$ slope, with an additional advantage of livestock feed as a co-benefit.

Chapter 5 examines the functioning and effectiveness of sediment storage dams (SSDs) as an off-site ST measure within gullies and drainage channels. The amount of sediment trapped behind the structures was estimated and their STEs calculated. SSDs constructed from gabion and stone trapped an average of $1,584 \mathrm{t} \mathrm{y}^{-1}$ of the inflowing sediment with a STE of $74 \%$ and $67 \%$, respectively. SSDs reduce sediment connectivity through disconnecting sediment transfer pathways inside drainage channels and gullies. SSDs also reduce channel slope gradients in addition to re-filling gullies. In general, although SSDs might be costly for small scale farmers and have a relatively short life span depending on their size, they are promising off-site structural measures to trap significant amounts of sediment at the outlets of sub-catchments and subsequently reducing sediment movement to downstream water bodies or reservoirs.

Chapter 6 presents the sediment disconnecting role of man-made and natural sediment sinks and enables to quantify the trapped sediment behind man-made structures and within natural sediment sinks. It also enables to know the STE of man-made (Soil bund and fanya Juu) and natural sediment sinks (a wetland, a floodplain and grassed waterways). Results reveal that soil bunds and fanya juu ridges, a floodplain and a wetland trapped sediment at the rate of $55 \mathrm{~kg} \mathrm{~m}^{-1} \mathrm{y}^{-1} ; 59 \mathrm{~kg} \mathrm{~m}^{-2} \mathrm{y}^{-1}$ and 36 $\mathrm{kg} \mathrm{m}^{-2} \mathrm{y}^{-1}$ with STEs of $54 \%, 77 \%$ and $85 \%$, respectively. A micro-trench on average trapped $23 \mathrm{~kg} \mathrm{y}^{-1}$ of sediment annually and substantial differences were observed between the STE of grassed and ungrassed waterways at $75 \%$ and $21 \%$, respectively. Over 20 years old, fanya juu ridges have reduced 
the average slope gradient by $2.7 \%$ forming lines of high sediment ridges unlike the soil bunds, in which the trapped sediment is buried inside the ditch instead of forming lines of sediment ridges, which reduces its role in changing the gradient of the slope.

Although existing man-made and natural sediment sinks trapped $38 \%(26,600 \mathrm{t})$ of the transported sediment, $62 \%(43,000 \mathrm{t})$ is still leaving the catchment and entering Koga reservoir (Chapter 2). Lack of an integrated ST approach, in which emphasis is given to both on-site sediment sources and offsite sediment sources, is an important cause for such a large sediment export from the catchment.

Chapter $\mathbf{7}$ tries to identify the best approach for implementing a combination of sediment trapping measures within the Minizr catchment. We tried to adapt an existing spatial model (LAPSUS_D model) for runoff and sediment prediction. Unfortunately, the calibration and validation results were not promising. Our objective to evaluate the integrated ST role of sediment trapping measures at catchment scale was not put into action. Therefore, further study is recommended to adapt a daily resolution model and run scenarios for a more integrated approach.

The final chapter is a synthesis of previous chapters. It not only summarizes the main results but also discusses the scientific value of the thesis and its limitations. Furthermore, attention is given to recommendations for policy, extension and further research. 


\section{SENSE}

Netherlands Research School for the

Socio-Economic and Natural Sciences of the Environment

\section{I P L O M A}

For specialised PhD training

The Netherlands Research School for the Socio-Economic and Natural Sciences of the Environment (SENSE) declares that

\section{Mulatie Mekonnen Getahun}

born on 2 September 1977 in Gojam, Ethiopia

has successfully fulfilled all requirements of the Educational Programme of SENSE.

Wageningen, 14 December 2016

the Chairman of the SENSE board

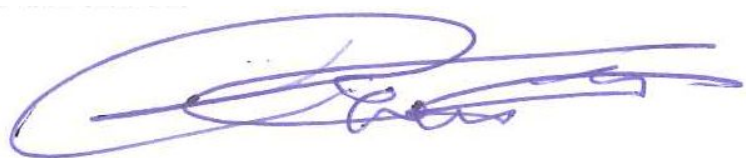

Prof. dr. Huub Rijnaarts the SENSE Director of Education

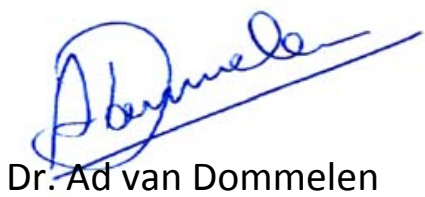

The SENSE Research School has been accredited by the Royal Netherlands Academy of Arts and Sciences (KNAW)

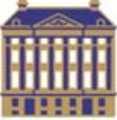

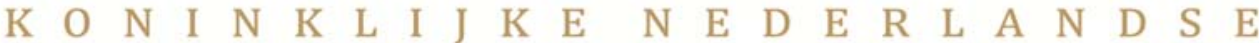

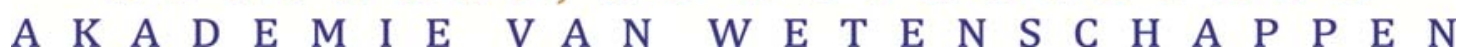




\section{SENSE}

The SENSE Research School declares that Mr Mulatie Mekonnen Getahun has successfully fulfilled all requirements of the Educational PhD Programme of SENSE with a work load of $44.6 \mathrm{EC}$, including the following activities:

\section{$\underline{\text { SENSE PhD Courses }}$}

- Environmental research in context (2014)

o Research in context activity: 'Organising a field visit with farmers participating on the subject of sediment trapping efficacy of indigenous grass species, Debre Mewi watershed, NW Ethiopia' (2014)

\section{Other PhD and Advanced MSc Courses}

- Information literacy including EndNote introduction, Wageningen University (2012)

- Techniques for writing and presenting a scientific paper, Wageningen University (2013)

- Erosion processes and modelling, Wageningen University (2013)

- Project and time management, Wageningen University (2014)

- Training course on soil mapping, classification and assessment for soil and environmental scientists, Hands-on Global Soil Information Facilities (GSIF), organised by ISRIC - World Soil Information, Wageningen (2016)

\section{Management and Didactic Skills Training}

- Supervising MSc student with thesis entitled 'Low-land gully formation in the Amhara region, Ethiopia' (2014)

\section{Oral Presentations}

- Sediment storage dam: A structural gully erosion control and sediment trapping measure, NW Ethiopia. European Geoscience Union (EGU) General Assembly, 27 April-2 May 2014, Vienna, Austria

- GIS and remote sensing based forest resource assessment, quantification and mapping in Amhara region, Ethiopia. Ethiopian Forestry Society (EFS) $3^{\text {rd }}$ Annual Conference, 22-24 December 2014, Bahir Dar, Ethiopia

- Evaluating the sediment trapping efficacy of indigenous grass species, NW Ethiopian highlands. TropiLakes 2015 Conference: Tropical lakes in a changing environment, 23-29 September 2015, Bahir Dar, Ethiopia

SENSE Coordinator PhD Education

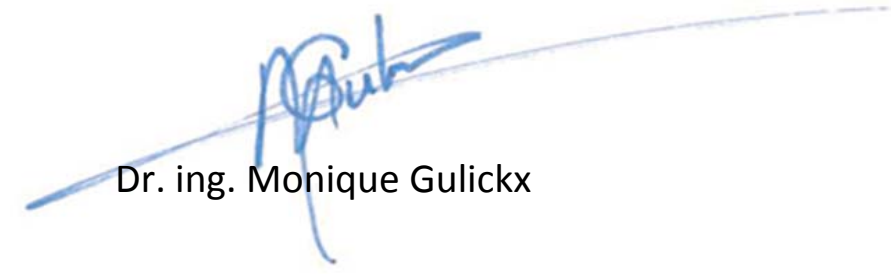




\section{Curriculum vitae and author's publications}

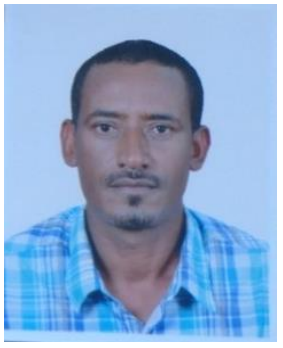

Mulatie Mekonnen Getahun was born on September 2, 1977 in Gojam, Ethiopia. He finished his secondary education from Adet, in 1990. Mulatie has obtained his Diploma in Agricultural Engineering from Awassa College of Agriculture in 1992 and his Bachelor Degree in Geography and Pedagogical Science from Bahir Dar University in 2004. He started the MSc program at Bahir Dar university in collaboration with TFH University of Applied Science, Germany and specialized in Geo-Information Science (GIS) from September 2007 to June 2009. Mulatie has been involved both in research and development programs: He was a regional watershed management and development expert in MERET (Managing Environmental Resources to Enable Transition) project; and GIS specialist in the Amhara National Regional State Bureau of Agriculture; Research Technical Assistant (RTA) in natural resource conservation and management research department at Adet Agricultural research center; and Soil and Water Conservation expert in the Ministry Natural Resources Conservation and Environmental Protection. He also served as a focal person for Amhara Micro-enterprise development, Agricultural Research, Extension and Watershed Management (AMAREW) Project in the Bureau of Agriculture.

Mulatie followed short term trainings on: GIS based database management; application of GIS and Remote Sensing for integrated water resource management (IWRM); Remote Sensing and Image Analysis; land rehabilitation, productivity improvement and income generating technologies; Local Level Participatory Planning Approach (LLPPA) for natural resource conservation at watershed scale; Water harvesting technologies and spring development techniques; community based participatory watershed development planning for productive safety net.

Mulatie provided many skill oriented trainings on: (i) Applications of GIS, topographic map, DEM, Satellite Imagery and GPS for watershed delineation, natural resource mapping, integrated watershed conservation and management planning to regional, zonal and district level soil and water conservation professionals working in Sustainable Water harvesting and Institutional Strengthening in Amhara (SWHISA) project; Sustainable Land Management (SLM) project; Productive Safety Net Program (PSNP) and the Bureau of Agriculture (BoA).

In September 2012, Mulatie started his Sandwich PhD at Wageningen University, Soil Physics and Land management (SLM) Group with NUFFIC sponsorship and finalized in August 2016. His PhD research focused on 'Sustaining reservoir use through sediment trapping in NW Ethiopia'. During this period, he has published a number of peer reviewed articles and made a number of oral and poster presentations in national and international meetings.

Mulatie Mekonnen married Ethiopia Abesha in 1993 and have two daughters (Nardos Mulatie, and Mahilet Mulatie) and one son (Kaleab Mulatie). He would like to continue in research on soil conservation and watershed management, sediment dynamics, land-scape connectivity, GIS and Remote Sensing.

Email: mulatiemekonneng@gmail.com 


\section{Publications}

Peer reviewed Journal papers

Mekonnen, M., Keesstra, S.D., Ritsema, C.J., Stroosnijder, L., Baartman, J.E.M. 2016. Sediment trapping with indigenous grass species showing differences in plant traits in northwest Ethiopia. Accepted, CATENA Journal.

Mekonnen, M., Keesstra, S.D., Baartman, J.E.M., Stroosnijder, L., Maroulis, J. 2016. Reducing sediment connectivity through man-made and natural sediment sinks in Minizr catchment, nothwest Ethiopia. Accepted, Land Degrad Dev.Journal.

Mekonnen, M., Keesstra, S.D., Baartman, J.E.M., Ritsema, C.J., Melesse, A.M. 2015. Evaluating sediment storage dams: Structural off-site sediment trapping measures in northwest Ethiopia. Cuadernos de Investigacion Geografica 41: 7-22. DOI: 10.18172/cig.2643

Mekonnen, M., Keesstra, S.D., Stroosnijder, L., Baartman, J.E.M., Maroulis, J. 2014. Soil conservation through sediment trapping: a review. Land Degradation and Development 26, 544-556. DOI: 10.1002/ldr.2308

Book Chapters

Mekonnen, M., Sewunet,T., Gebeyeh, M., Azene, B., Melesse, A.M. 2015. GIS and Remote SensingBased Forest Resource Assessment, Quantification and Mapping in Amhara Region, Ethiopia. Melesse A.M. and Abtew W. (Eds.), Landscape Dynamics, Soil and Hydrological Processes in Varied Climates, Springer Geography. Springer International Publishing, Switzerland, 9-29.

Mekonnen, M., Melesse, A.M., Kesstra, S.D. 2015. Spatial Runoff Estimation and Mapping of Potential Water Harvesting Sites: A GIS and Remote Sensing perspective, northwest Ethiopia. Melesse A.M. and Abtew W. (Eds.), Landscape Dynamics, Soil and Hydrological Processes in Varied Climates, Springer Geography. Springer International Publishing, Switzerland 565-584.

Engdayehu, G., Fisseha, G., Mekonnen, M., Melesse, A.M. 2015. Evaluating Technical Standards of Physical Soil and water Conservation practices and their Role in Soil Loss Reduction: The case of Debre Mewi Watershed, north-west Ethiopia. Melesse A.M. and Abtew W. (Eds.), Landscape Dynamics, Soil and Hydrological Processes in Varied Climates, Springer Geography. Springer International Publishing, Switzerland 789-818.

Mekonnen, M., Melesse, A.M. 2011. Soil Erosion Mapping and Hotspot area identification using GIS and Remote Sensing in Northwest Ethiopian Highlands, near Lake Tana. in: Melesse AM. editor. Nile River Basin hydrology climate \& water use. Switzerland Springer: 207-224.

\section{Conference presentations /posters}

Mekonnen, M., Keesstra, S.D., Ritsema, C.J., Stroosnijder, L., Baartman, J.E.M. 2016. Evaluating indigenous grass species as on-site sediment trapping measures, northwest Ethiopian highlands. European Geoscience Union General Assembly 2016, April 17-22, 2016, Austria Vienna.

Mekonnen, M., Keesstra, S.D., Ritsema, C.J., Stroosnijder, L., Baartman, J.E.M. 2016. Assessing the integrated sediment trapping role of man-made and natural sediment sinks, Minizr catchment, Ethiopia. European Geoscience Union General Assembly 2016, April 17-22, 2016, Austria Vienna. 
Mekonnen, M., Keesstra, S.D., Ritsema, C.J., Stroosnijder, L., Baartman, J.E.M. 2015. Evaluating the sediment trapping efficacy of indigenous grass species, north-west Ethiopian highlands. International Conference on TROPILAKES2015, Tropical lakes in a changing environment: Water, Land, Biology, Climate and Humans, Sept 23-29, 2015, Bahir Dar, Ethiopia.

Mekonnen, M., Keesstra, S.D., Baartman, J.E.M., Ritsema, C.J. 2014. Sediment Storage Dam-A structural gully erosion control and sediment trapping measure NW Ethiopia. European Geoscience Union General Assembly 2014, 27 April-02 May 2014, Austria, Vienna.

Mekonnen, m., Keesstra, S.D., Baartman, J.E.M., Stroosnijder, L., Maroulis, J. 2014. Soil Conservation Through Sediment Trapping: A review. European Geoscience Union General Assembly 2014, 27 April-02 May 2014, Austria Vienna.

Mekonnen, M., Sewunet, T., Gebeyehu, M., Azene, B., Melesse, A.M. 2014. GIS and Remote Sensing Based Forest Resource Assessment, Quantification and Mapping in Amhara Region, Ethiopia.

Ethiopian Forestry Society $3^{\text {rd }}$ National Conference. December 22-24, 2014, Bahir Dar, Ethiopia.

Mekonnen, M., Melesse, A.M. 2010. Spatial Runoff and Mapping of Potential Water Harvesting Areas: A GIS and Remote Sensing Perspective, Debre Mewi, Ethiopia. International Conference of Water Resources in Ethiopia. 12-16 January, 2010, Addis Ababa, Ethiopia.

\section{Master Thesis}

Mekonnen, M. Soil Erosion Assessment, Runoff Estimation and Water Harvesting Site Selection using GIS and Remote Sensing at Debre Mewi Watershed, Amhara Region, Ethiopia. Master thesis. Bahir Dar University, Bahir Dar, Ethiopia. p96.

\section{Submitted paper}

Mekonnen, M., Keesstra, S.D., Baartman, J.E.M., Stroosnijder, L., Masselink, R.J.H. 2016. Spatial and temporal variations of sediment entering Koga reservoir, NW Ethiopia. Earth Surface Processes and Landforms. 
